The Afghanistan Analyst Bibliography

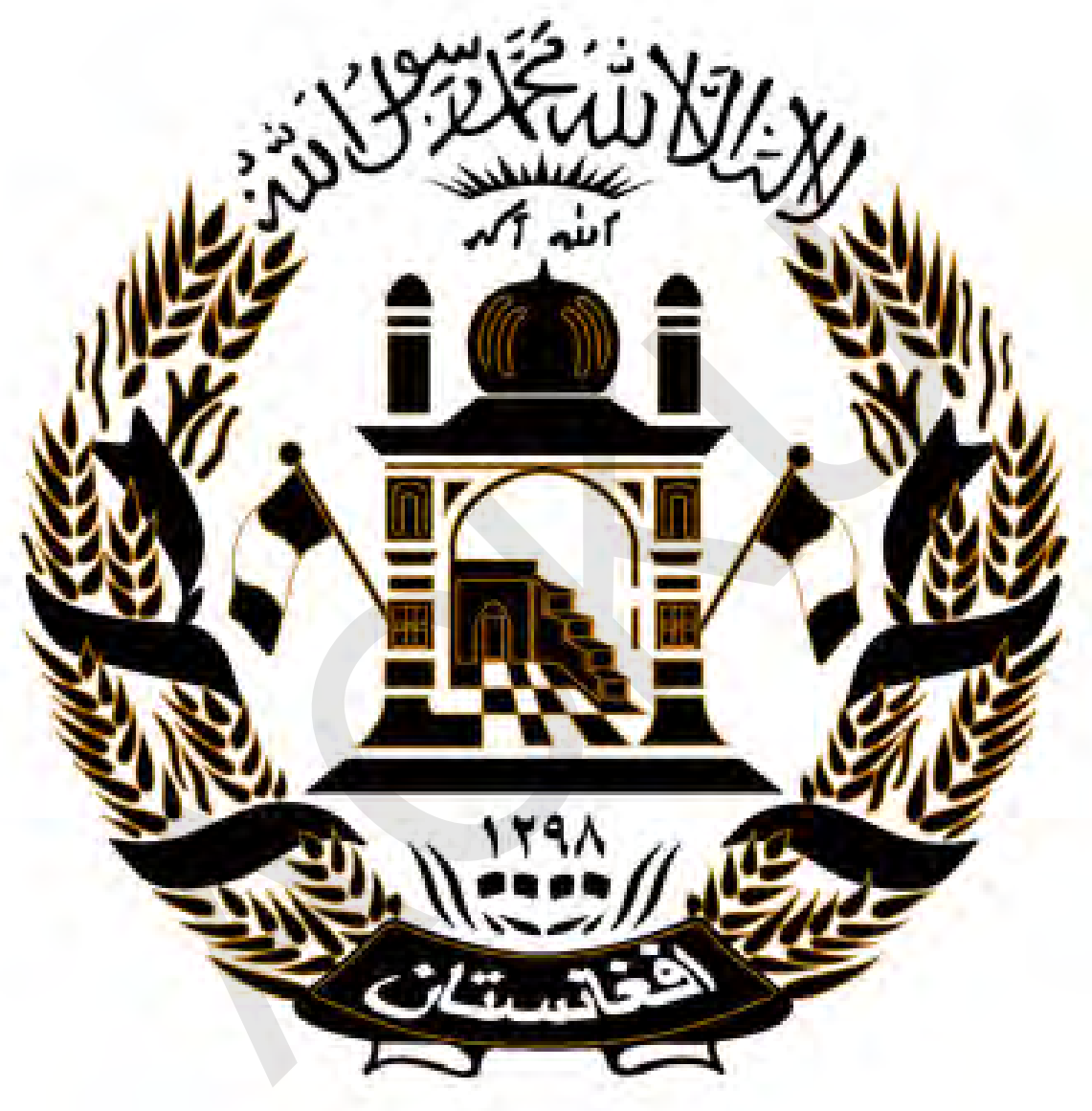

$$
\begin{aligned}
& 6^{\text {th }} \text { Edition - July } 2011 \\
& \text { Compiled by Christian Bleuer }
\end{aligned}
$$




\title{
The Afghanistan Analyst Bibliography
}

\author{
$6^{\text {th }}$ Edition - July 2011
}

\author{
Compiled by: Christian Bleuer \\ PhD Candidate, Centre for Arab and Islamic Studies \\ (Middle East and Central Asia) \\ The Australian National University \\ contact@afghanistan-analyst.org
}

Published by The Afghanistan Analyst

http://afghanistan-analyst.org

Check for updated versions of this bibliography at:

http://afghanistan-analyst.org/bibliography.aspx 


\section{Table of Contents}

Introduction. page 4 .

1. Ethnic Groups. page 5 .

2. Conflict and Mobilization: War, Ethnicity, Jihad, Taliban, Factions, "Warlords," etc... (Late 1970s to the present). .page 33.

3. Islam: Political Islam, Sharia, “Jihad”, Sects and Religious Affairs. page 60 .

4. State-Building: The International Community, Reconstruction, Security, Economy, Government and Development.

page 67.

5. Policy: Announcements, Recommendations and Criticisms. page 114.

6. Opium: Cultivation, Drug Use and Trafficking. page 131.

7. Land: Environment, Agriculture, Property Issues, and Natural Resources. page 143.

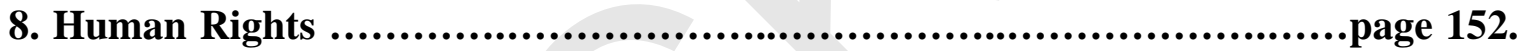

9. Women, Gender and Family.............................................page 160 .

10. Military: Operations, Civil-Military Relations, PRTs and COIN..........page 171.

11. Security Sector: DDR, Militias, Afghan National Army and Police, PMCs and Security Contractors. page 193.

12. Population Movements: Refugees, IDPs and Migration page 199.

13. Health and Medicine. page 207.

14. Education. page 210 .

15. Macro and Micro Economics page 212.

16. Public Opinion: Interviews, Study Groups, Polls and Surveys...............page 218.

17. Periodicals and Academic Journals. page 221.

18. Law Bibliography by Tim Mathews. page 223. 


\section{The Afghanistan Analyst Bibliography Introduction}

This bibliography is intended to be an up-to-date resource for studying and researching contemporary Afghanistan. The vast majority of sources included are from after the late 1970s, except for in the bibliography section on ethnic groups and, to a lesser extent, on Islam. I did not compile sources on linguistics, art, literature, pre-/mid-20 ${ }^{\text {th }}$ Century history or on the natural sciences (unless applied to resource management), and the sources on the Soviet-Afghan war are limited (a specific section on the Soviet-Afghan War may be added in the future). You should be able to find sources such as these in some of the various standard Afghanistan bibliographies that have been published in book form. However, these bibliographies are usually poor in regards to more recent sources.

This bibliography will remain confined to sources published in English, with a few select sources in French, German and Russian. It will be updated approximately once per year to include newly published sources plus older sources that were inadvertently omitted. Check the website for new editions. If you would like to suggest a book or other source for inclusion, preferably from an academic journal or well-established research institute, please send your suggestion to contact@afghanistan-analyst.org

Due to time and budget constraints, the next edition may not be published until 2013.

Christian Bleuer

Canberra, Australia. 


\section{Ethnic Groups}

\subsection{Pashtun}

1.2 Hazara

1.3 Uzbek

1.4 Turkmen

1.5 Nuristani

1.6 Tajik

1.7 Baluch

1.8 Pashai

1.9 Other/various groups

Note: The sources in this section are not confined strictly to ethnographies. And in regards to Pashtuns and Baluchis, some studies from Pakistan are included. Ethnic categories are used here loosely for ease of categorization.

\subsection{Pashtun}

\section{$\underline{\text { Books }}$}

Abdul Quddus, Syed. 1987. The Pathans. Lahore: Ferozsons.

Ahmed, Akbar. 1980. Pakhtun Economy and Society. London: Routledge and Kegan Paul.

Ahmed, Akbar. 1976. Millenium and Charisma Among Pathans. London: Routledge.

Banerjee, Mukulika. 2000. The Pathan Unarmed: Opposition \& Memory in the North West Frontier. School of American Research Press.

Barth, Frederick. 1959. Political Leadership Among Swat Pathans. LSE Monograph Series, NY: Humanities Press

Barth, Fredrik. 1981. Features of Person and Society in Swat: Collected Essays on Pathans. Routledge \& Kegan Paul.

Berrenberg, Jeanne. 2002. Eine Sache der Ehre: Uber die Grundlagen Sozialer Prozesse bei den Pashtunen Pakistans und Afghanistans Anhand Ihrer Heirastformen. Frankfurt am Main: Lang.

Caroe, Olaf. 2000 (reprint of 1958 edition). The Pathans: 500 B.C.-A.D. 1957. London: Kegan Paul International. 
Dessart, Laurent. 2001. Les Pachtounes: Economie et Culture d'une Aristocratie Guerriere. Paris: L’Harmattan.

Edwards, David B. 1996. Heroes of the Age: Moral Fault Lines on the Afghan Frontier. Berkeley, CA: University of California Press.

Ferdinand, Klaus. 2006. Afghan Nomads: Caravans, Conflicts and Trade in Afghanistan and British India 1800-1980. Copenhagen: Rhodos International.

Glatzer, B. 1977. Nomaden von Gharjistan. Wiesbaden.

Grima, Benedicte. 1992. The Performance of Emotion Among Paxtun Women: "The Misfortunes Which Have Befallen Me.” Austin, TX: University of Texas Press.

Hussain, S. Iftikhar. 2000, 1990. Some major Pukhtoon tribes along the Pak-Afghan border. [Edited by M.Y. Effendi]. Peshawar: Area Study Centre Peshawar and Hanns Seidel Foundation, 2000. Originally a PhD. thesis: Peshawar University, 1990.

Jentsch, C. 1973. Das Nomadentum in Afghanistan (Afghanische Studien 9), Meisenheim.

Khan, G. 1958. The Pathans: A Sketch. Peshawar: University Books.

Kuhnert, G. 1980. Falknerei in Afghanistan. Bonn.

Lebedev, Konstatin. 1997. Afganskii Narod: Pashtuny. Moscow: Nauka.

Lindholm, Charles. 1996. Frontier Perspectives. Oxford University Press Pakistan.

Lindholm, C. 1982. Generosity and Jealousy: The Swat Pukhtun of Northern Pakistan. New York: Columbia University Press.

Nichols, Robert. 2008. A History of Pashtun Migration, 1775-2006. Oxford U Press.

Pedersen, Gorm. 1995. Afghan Nomads in Transition: A Century of Change Among the Zala Khan Khel. Thames \& Hudson.

Poullada, Leon B. 1970. The Pushtun Role in the Afghan Political System. New York: Afghanistan Council of the Asia Society.

Quddus, S.A. 1987. The Pathans. Lahore: Ferozsons.

Rittenberg, Stephen Alan. 1988. Ethnicity, nationalism, and the Pakhtuns: the independence movement in India's North-west Frontier Province. Durham, N.C.: Carolina Academic Press.

Spain, J. 1963. The Pathan Borderland. The Hague: Mouton. 
Steul, Willi. 1981. Paschtunwali: Ein Ehrenkodex und seine rechtliche Relevanz. Wiesbaden: Steiner Verlag.

Tapper, Nancy. 1991. Bartered Brides: Politics, Gender and Marriage in an Afghan Tribal Society. Cambridge: Cambridge University Press.

Temirkhanov, L. 1987. Vostochnye pushtuny: osnovnye problemy novoi istorii. Nauka.

Temirkhanov, L. 1984. Vostochnye pushtuny v novoe vremia. Moscow: Nauka.

Wald, Hermann Josef. 1969. Landnutzung und Siedlung der Pashtunen im Becken von Khost (ostl. Afghanistan). Opladen: Leske.

Weinreich, Matthias. 2008. "We Are Here to Stay": Pashtun Migrants in the Northern Areas of Pakistan. Islamkundliche Untersuchungen Band 285. Klaus Schwarz Verlag.

\section{$\underline{\text { Articles, report and book chapters }}$}

Ahady, Anwar-ul-Haq. 1995. 'The Decline of the Pashtuns in Afghanistan', Asian Survey, Vol. 35, No. 7 (July 1995), pp. 621-634.

Ahmed, Aisha and Roger Boase. 2008. Pashtun Tales: From the Pakistan-Afghan Frontier. Saqi Books.

Ahmed, Akbar S. 1984. 'Religious presence and symbolism in Pukhtun society', in Islam in Tribal societies, from the Atlas to the Indus. Akbar S. Ahmed and D.M. Hart (editors). London: Routledge \& Kegan Paul.

Anderson, J. 1975. 'Tribe and community among the Ghilzai Pashtun: Preliminary notes on ethnographic distribution and variation in Eastern Afghanistan', Anthropos, 70 (1975).

Anderson, J. W. 1982. Cousin Marriage in Context: Constructing Social Relations in Afghanistan, Folk, Vol. 24, pp. 7-28.

Anderson, J. W. 1983. 'Khan and Khel: dialects of Pakhtun tribalism', in The conflict of Tribe and State in Iran and Afghanistan. Richard Tapper (editor) St. Martin's Press.

Anderson, J.W. 1985. 'Sentimental Ambivalence and the Exegesis of "Self" in Afghanistan’, Anthropological Quarterly, Vol. 58, No. 4, pp. 203-211.

Anderson, J. W. 1978. 'There are no Khans anymore: economic development and social change in tribal Afghanistan', in Middle East Journal, 32. 
ARRC. 2009. 'My Cousin’s Enemy is My Friend: A Study of Pashtun “Tribes” in Afghanistan', Afghanistan Research Reachback Center White Paper. TRADOC G2 Human Terrain System. United States Army. Fort Leavenworth, KS. Download PDF.

Atayee, Ibrahim. 1979. A dictionary of the terminology of Pashtun's tribal customary law and usages. Translated by A. Mohammad Shinwary. Edited by A. Jabar Nader. Kabul: International Centre for Pashto Studies, Academy of Sciences of Afghanistan.

Balikci, Asen. 1990. 'Tenure and transhumance: stratification and pastoralism among the Lakenkhel', in The world of pastoralism: herding systems in comparative perspective. Eds. John G. Galaty, Douglas L. Johnson. New York; London: The Guilford Press.

Balikci, Asen. 1981. 'Pastoralism and class differentiation among the Lakenkhel', in Change and development in nomadic and pastoral society. Ed. by John G. Galaty. Leiden: E.J. Brill, pp. 150-157.

Balland, M. Daniel. 1995. 'Du mythe a l'histoire: Aux origins du chi'ism chez Pastun', Journal Asiatique, 282(2), pages 351-372.

Balland, Daniel. 1988. 'Contribution à l'étude du changement d'identité ethnique chez les nomades d'Afghanistan', in Le fait ethnique en Iran et en Afghanistan. Dir. Jean-Pierre Digard. Paris: Ed. du CNRS, pp. 139-155.

Balland, D. 1974. 'Vieux sédentaire tadjik, les immigrants Pachtoun dans le sillon de Ghazni (Afghanistan oriental)', Bulletin de l'Assoc. des géographes français, Vol. 51.

Barfield, Thomas J. 2007. 'Weapons of the not so Weak in Afghanistan: Pashtun Agrarian Structure and Tribal Organization for Times of War \& Peace', Agrarian Studies Colloquium Series "Hinterlands, Frontiers, Cities and States: Transactions and Identities" Yale University. Download PDF.

Barfield, Thomas J. 1978. 'The Impact of Pashtun Immigration on Nomadic Pastoralism in northeastern Afghanistan', in Ethnic Processes and Intergroup Relations in Contemporary Afghanistan. Jon Anderson and Richard Strand (editors). NY: Asia society, Afghanistan Council. Occasional paper No. 15.

Barth, Fredrik. 1969. 'Pathan Identity and its Maintainance', in Ethnic Groups and Boundaries. Fredrik Barth (editor). Oslo: Universitetfordslaget.

Beattie, H. 1982. Kinship and Ethnicity in the Nahrin Area of Northern Afghanistan Afghan Studies, Vol. 3-4, pp. 39-51.

Berea, Anamaria. 2010. 'Economic Processes and Network Dynamics in the Pashtun Tribes’, Center for Social Complexity, George Mason University. Download PDF. 
Berrengen, Jeanne. 2003. 'Beyond kinship algebra: values and the riddle of Pashtun marriage structure’, Zeitschrift fur Ethnologie, Vol. 128 ii, pages 269-292.

Boeson, Inger W. 1980. 'Women, Honour and Love: Some Aspects for the Pashtu Woman’s Life in Eastern Afghanistan', Afghanistan Journal, 7(2): pp. 50-59.

Burleson, William E. 2008. 'The Kinsey Scale and the Pashtun: The Role of Culture in Measuring Sexual Orientation', Journal of Bisexuality, Vol. 8, No. 3.

Caron, James M. 2007. 'Afghanistan Historiography and Pashtun Islam: Modernization Theory’s Afterimage,’ History Compass, 5/2 (2007): 314-329.

Christensen, Asger. 1982. 'Agnates, affines and allies: patterns of marriage among Pakhtun in Kunar, North-East Afghanistan’, Folk, Vol. 24, pp. 29-63.

Christensen, Asger. 1980. 'The Pashtuns of Kunar: Tribe, Class and Community Organization’, Afghanistan Journal 7(3): pp. 79-92.

Christensen, A. 1980. 'Organization, variation and transformation in Pukhtun society: review article’, Ethnos, 46, pages 96-108.

Dupree, Louis. 1978. 'Pushtun', in Richard V. Weeks (editor), Muslim Peoples: A World Ethnographic Survey. Westport, CT and London: Greenwood Press.

Dupree, L. 1956. 'The Changing Character of South-central Afghanistan Villages', Human Organization, Vol. 14, pp. 26-29.

Edwards, David B. 1986. 'Charismatic leadership and political process in Afghanistan,' Central Asian Survey, Volume 5, Issue 3/4, pp. 273-299.

Edwards, David. 1998. 'Learning from the Swat Pathans: political leadership in Afghanistan, 1978-1997’, American Ethnologist, Vol 25, No 4.

Fearon, Kate. 2010. 'Proximity, Pragmatism and Pashtunwali: Informal Justice at District Level in Helmand Province’, UK Stabilisation Unit. Download Word Doc.

Ferdinand, Klaus. 1982. 'Marriage among Pakhtun nomads of Eastern Afghanistan', Folk, Vol. 24, pp. 65-87.

Ferdinand, K. 1969. 'Nomadism in Afghanistan', in Viehwirtschaft und Hirtenkultur, ed. L. Föeldes and B. Gunda, Budapest, pp. 127-60.

Ferdinand, K. 1962. 'Nomad Expansion and Commerce in Central Afghanistan', Folk, Vol. 4, pp. 123-59. 
Ghani, M. A. 1976. 'A Critique of Sir Olaf Caroe. Towards an Anthropological Understanding of Tribalism and Centralism in Afghanistan,' Afghanistan, Vol. 29, No. 2.

Glatzer, Bernt. 2002. ‘The Pashtun tribal system', in Concepts of tribal society. Georg Pfeffer and Deepak Kumar Behera (editors). Delhi: Concept Publishing Co.

Glatzer, Bernt. 2001. 'War and Boundaries in Afghanistan: significance of local and social boundaries’, Weld des Islams, 41(3), pages 379-99. Download PDF.

Glatzer, Bernt. 1998. 'Being Pashtun - being Muslim: concepts of person and war in Afghanistan', in Essays on South Asian Society, Culture and Politics II. Bernt Glatzer (editor). Berlin: Zentrum Moderner Orient. Pages 83- 94. Download PDF.

Glatzer, Bernt. 1996. 'Dynamics of camp formation among Pashtun nomads in west Afghanistan’, Nomadic Peoples, 39 (1996), pages 29-52.

Glatzer, Bernt. 1983. 'Political organization of Pashtun nomads and the state', in The Conflict of Tribe and State in Iran and Afghanistan. R. Tapper (ed.) St. Martin’s Press.

Human Rights Watch. 2002. 'Paying for the Taliban’s Crimes: Abuses Against Ethnic Pashtuns in Northern Afghanistan’, Human Rights Watch Report, 14(2) (C). PDF.

International Crisis Group. 2003. 'Afghanistan: The Problem of Pashtun Alienation', International Crisis Group Asia Report, No. 62. Download PDF.

Janata, Alfred. 1987. 'Constituents of Pashtun Ethnic Identity: The Jaji Case’, Studia Iranica 16: pp. 201-214.

Janata, A. 1975. 'Ghairatman—Der gute Pashtune,” Afghanistan Journal, Vol. 2, No. 3.

Johansen, Robert C. 1997. 'Radical Islam and Nonviolence: A Case Study of Religious Empowerment and Constraint among Pashtuns’, Journal of Peace Research, 34 (1).

Johnson, Douglas Leslie. 1974. 'The Pashtûn nomads of Afghanistan', in The nature of nomadism. Douglas L. Johnson. Chicago: The University of Chicago. [Diss. 1969].

Karzai, Hamed. 1988. 'Attitude of the Leadership of Afghan Tribes Towards the Regime from 1953 to 1978’, Central Asian Survey, Vol. 7, No. 2/3.

Katkov, I.E. 1989. 'Sotsial'nye aspekty plemennoi struktury pushtunov', in Afganistan: Istoriya, ekonomika, kul'tura (sbornik statei), Moscow: Nauka.

Kfir, Isaac. 2009. 'The Role of the Pashtuns in Understanding the Afghan Crisis', Vol. 3, No 4. Download PDF. 
Khan, Ijaz. 2007. 'Pashtuns in the Crossfire: Pashtun Politics in the Shadow of 'War against Terrorism’, Pakistan Security Research Unit, Brief No. 19. Download PDF.

Lamb, Robert D. and Amin Tarzi. 2011. 'Measuring Perceptions about the Pashtun People', CSIS. Download PDF.

Lindholm, Charles. 2010. 'Pukhtun Identity in Swat, Northern Pakistan', in Ethnicity, Authority, and Power in Central Asia: New Games Great and Small. Edited by Robert L. Canfield and Gabriele Rasuly-Paleczek. Routledge.

Lindholm, C. 1981. 'The Structure of Violence among the Swat Pukhtun', Ethnology, 20:2, 147-56.

Lindholm, Charles. 1980. 'Images of the Pathan: The Usefulness of Colonial Ethnography’, European Journal of Sociology, Vol. 21: 350-61.

Miakhel, Shahmahmood. 2008. 'The Importance of Tribal Structures and Pakhtunwali in Afghanistan', in Challenges and dilemmas of state-building in Afghanistan: report of a study trip to Kabul. Edited by Arpita Basu Roy. Download PDF.

Matsui, T. 1980. 'The Pastoral Life of the Durrani Pashtun Nomads in Northeastern Afghanistan', Social Survey Report of the Research Inst. for Humanistic Studies No. 33.

Nichols, Robert. 2010. 'An Interregional History of Pashtun Migration, c. 1775-2000’, in Ethnicity, Authority, and Power in Central Asia: New Games Great and Small. Edited by Robert L. Canfield and Gabriele Rasuly-Paleczek. Routledge.

Niloufer Qasim Mahdi, 1986. 'Pakhtunwali: Ostracism and Honor among the Pathan Hill Tribes,' Ethology and Sociobiology 7 (1986): 150-54.

Pedersen, G. 1981. 'Socio-economic Change among a Group of East Afghan Nomads', Afghanistan Journal, Vol. 8, pp. 115-22.

Poullada, Leon B. 1970. 'The Pushtun role in the Afghan political system', Afghanistan Council of the Asia Society, Occasional Paper No. 1.

Pstrusinska, J. 1992-93. 'Contemporary status of the Pashtun', Afghanica, 6-7/ 11-13.

Rieck, Andreas. 1997. 'Afghanistan’s Taliban: An Islamic Revolution of the Pashtuns', Orient, Vol. 38, No. 1.

Rzehak, Lutz. 2011. 'Doing Pashto: Pashtunwali as the ideal of honourable behaviour and tribal life Among the Pashtuns', Afghanistan Analysts Network. Download PDF.

Saikal, Amin. 2010. 'Afghanistan and Pakistan: The Question of Pashtun Nationalism?’, Journal of Muslim Minority Affairs, Vol. 30, No. 1. 
Scott, Richard B. 1980. 'Tribal \& ethnic groups in the Helmand Valley', Occasional paper No. 21. (Asia Society. Afghanistan Council) New York. Download PDF.

Sinno, Abdulkader. 2008. 'Explaining the Taliban’s Ability to Mobilize the Pashtuns', in Robert D Crews and Amin Tarzi (editors). The Taliban and the Crisis of Afghanistan. Cambridge, MA: Harvard University Press.

Southwold-Llewellyn, Sarah. 2006. 'Devolution of Forest Management: A Cautionary Case of Pukhtun Jirgas in Dispute Settlements', Human Ecology. Vol. 34, No. 5.

Southwold-Llewellyn, Sarah. 2005. 'Forest management in a Pukhtun community: the Constructions of Identities’, in G. Cederlof \& K. Sivaramakrishnan (Eds.), Ecological nationalisms: Nature, livelihoods and identities in South Asia. New Delhi: Permanent Black/Orient Longman.

Tapper, Nancy. 1983. 'Acculturation in Afghan Turkistan: Pashtun and Uzbek women', Asian Affairs, Volume 14, Issue 1, pages 35-44.

Tapper, Nancy. 1977. 'Pashtun nomad women in Afghanistan', Asian Affairs, 8(2).

Tapper, Nancy. 1973. 'The Advent of Pashtūn "Māldārs" in North-Western Afghanistan', Bulletin of the School of Oriental and African Studies, Vol. 36, No. 1.

Tapper, Richard. 1983. 'Introduction', iin The conflict of Tribe and State in Iran and Afghanistan. Richard Tapper (editor) New York: St. Martin’s Press.

Tapper, R. 1974. 'Nomadism in Modern Afghanistan', in Afghanistan in the 1970s, ed. L. Dupree and L. Albert, New York, pp. 126-43.

Tapper, Richard and Nancy Tapper. 1986. '"Eat This, It'll Do You a Power of Good": Food and Commensality among Durrani Pashtuns', American Ethnologist, Vol. 13, No. 1.

Tapper, Nancy and Richard Tapper. 1982. 'Marriage Preferences and Ethnic Relations among Durrani Pashtuns of Afghan Turkestan’, Folk, Vol. 24.

Tapper, Nancy. 1981. 'Direct exchange and brideprice: alternative forms in a complex marriage system’, Man, Vol. 16, pp. 387-407.

Tavakolian, Bahram. 1984. 'Women and socioeconomic change among Sheikhanzai nomads of western Afghanistan', The Middle East Journal, Vol. 38, p. 433-453. 


\section{Theses and Dissertations}

Abawi, Khalil Ahmad. 1962. Der Kampf des pachtunischen Volkes um die Unabhängigkeit seiner Heimat Pachtunistan: ein Selbstbestimmungsproblem in Zentralasien. Thesis (doctoral)--Rechts- und Staatswissenschaftlichen Fakultät der Albert-Ludwigs-Universität zu Freiburg im Breisgau.

Amato, Jonathan N. 2010. Tribes, Pashtunwali and how they impact reconciliation and reintegration efforts in Afghanistan. Georgetown University, Master's thesis.

Anderson, Jon Wilson. 1979. Doing Pakhtu: Social Organization of the Ghilzai Pakhtun. $\mathrm{PhD}$ dissertation, The University of North Carolina at Chapel Hill.

Bartlotti, Leonard. 2000. Negotiating Pakhto: Proverbs, Islam and the Construction of Identity Among Pashtuns. PhD dissertation, University of Wales.

Caron, James M. 2009. Cultural Histories of Pashtun Nationalism, Public Participation, and Social Inequality in Monarchic Afghanistan, 1905-1960. PhD dissertation, University of Pennsylvania.

Dessart, Laurent. 2000. Les Pachtounes: économie et culture d'une aristocratie guerrière (Afghanistan-Pakistan). Th. doct. --Muséum national d'histoire naturelle, Paris.

Evans-von Krbek, Jeffrey H.P. 1977. The Social Structure and Organization of a Pakhto Speaking Community in Afghanistan. PhD Dissertation, University of Durham.

Groh, Ty L. 2006. Ungoverned Spaces: the Challenges of Governing Tribal Societies. Naval Postgraduate School Thesis. Monterey, California (June 2006). Download PDF.

Hussain, Raja G. 2008. Badal, A Culture of Revenge: The Impact of Collateral Damage on Taliban Insurgency. Naval Postgraduate School Master's Thesis. Download PDF.

Khan, Shah Jehan. 1998. The religious leadership of Pushtuns. Thesis (Ph. D.)-University of Hawaii at Manoa.

Lindholm, Charles Thomas. 1979. Generosity and Jealousy: Social and Emotional Structures of the Swat Pakhtun. PhD dissertation, Columbia University.

Mohabbat, Ahmad Sha(h). 1979. Pakhtun National Self-Determination: The Partition of India and Relations with Pakistan. Ph.D. dissertation, Saint Louis University.

Oberson, José. 2002. Khans and Warlords: Political Alignment, Leadership and the State in Pashtun Society. Anthropological Aspects and the Warlordism Debate. Master's Thesis, Institute for Ethnology, Berne, Switzerland. Download PDF1 and PDF2. 
Zadran, Alef-Shah. 1977. Socioeconomic and Legal-Political Processes in a Pashtun Village, Southeastern Afghanistan. PhD Diss. State University of New York at Buffalo.

\subsection{Hazara}

\section{$\underline{\text { Books }}$}

Bindemann, Rolf. 1987. Religion und Politik bei den schi'itischen Hazâra in Afghanistan, Iran und Pakistan. Berlin: Verlag Das Arabische Buch.

Canfield, Robert L. 1973. Faction and Conversion in a Plural Society: Religious Alignments in the Hindu Kush. Ann Arbor, MI: University of Michigan.

Dulling, G. K. 1973. The Hazaragi Dialect of Afghan Persian: A Preliminary Study. London: Central Asian Research Centre.

Ferdinand, Klaus. 1959. Preliminary Notes on Hazara Culture: The Danish Scientific Mission to Afghanistan, 1953-55. Copenhagen: E. Munksgaard.

Grevemeyer, Jan-Heeren. 1985. Ethnizität und Nationalismus: die afghanischen Hazaras zwischen Emanzipation, Widerstand gegen die sowjetischen Besatzer und Burgerkrieg Berlin: Verlag Das Arabische Buch.

Kakar, M. Hasan 1973. The Pacification of the Hazaras of Afghanistan. New York: Afghanistan Council, Asia Society.

Monsutti, Alessandro. 2005. War and Migration: Social Networks and Economic Strategies of the Hazaras of Afghanistan. Translated by Patrick Camiller. Routledge.

Mousavi, Sayed Askar. 1997. The Hazaras of Afghanistan: An Historical, Cultural, Economic, and Political Study. New York: St. Martin’s Press.

Owtadolajam (Oftaadeh-Jam), Muhammad. 2006. A Sociological Study of Hazara Tribe in Balochistan: an analysis of socio-cultural change. University of Karachi PhD dissertation (1976), Quetta: Hazaragi Academy.

Poladi, Hassan. 1989. The Hazaras. Stockton, CA: Mughal Publishing.

\section{Articles, reports and book chapters}

Bacon, E. 1951. 'An Inquiry into the History of the Hazara Mongols of Afghanistan', Southwestern Journal of Anthropology, Vol. 7, pp. 230-47. 
Bindemann, Rolf. 2002. 'Hazara research and Hazara nationalism 1978-89' in Afghanistan - a Country Without a State? Christine Noelle-Karimi, Conrad Schetter, Reinhard Schlagintweit (editors). Frankfurt am Main: IKO, pages 77-85.

Canfield, Robert L. 2007. 'Recollections of a Hazara wedding in the 1930s', in Jeff Sahadeo and Russell Zanca (ed), Every Life in Central Asia. BIndiana University Press.

Canfield, Robert L. 2004. 'New trends among the Hazaras: from "the amity of the wolves" to "the practice of brotherhood”', Iranian Studies, 37(2), pages 241-262.

Canfield, Robert L. 1978. 'Hazara', in Richard V. Weeks (editor), Muslim Peoples: A World Ethnographic Survey. Westport, CT and London: Greenwood Press.

Canfield, Robert L. 1972. Hazara Integration into the Afghan Nation: Some Changing Relations Between the Hazaras and Afghan Officials. New York: Asia Society, Occasional Paper No. 3.

Dianous, H. 1961. ‘Hazaras et Mongols en Afghanistan’, Orient, Vol. 5, pp. 71-113.

Dupree, L. 1963. 'The Green and the Black', AUFS, Fieldstaff Reports, South Asia Series, $7 / 7$.

Emadi, Hafizullah. 1997. 'The Hazaras and their role in the political transformation in Afghanistan’, Central Asian Survey, 16(3), pages 363-387.

Ferdinand, K. 1964. 'Ethnographical Notes on the Chahar Aimaq, Hazara and Moghol', Acta Orientalia, Vol. 28, pp. 175-203.

Harpviken, Kristian Berg. 1998. 'The Hazaras of Afghanistan: an historical, cultural, economic, and political study', Central Asian Survey, 17(3).

Human Rights Watch. 2001. 'Massacres of Hazaras in Afghanistan', Human Rights Watch Report, Vol. 13, No. 1(C). Read online.

Ibrahimi, Niamatullah. 2009. 'The Dissipation of Political Capital among Afghanistan's Hazaras: 2001-2009’, Crisis states Working Paper No. 51 (series 2). Download PDF.

Ibrahimi, Niamatullah. 2006. 'The Failure of a Clerical Proto-State: Hazarajat, 1979-84', Crisis States Research Centre, Working paper No. 6 (Series 2). Download PDF.

Monsutti, Alessandro. 2004. 'Cooperation, remittances, and kinship among the Hazaras', Iranian Studies, 37(2), pages 219-240.

Razait, Husain and Tony Pearson. (n.d.) 'The Hazara People of Afghanistan: A century of Persecution.' 
Uhrig, R. 1999. 'Die Ethnie der Hazara in Afghanistan', Internationales Asienforum, 30(i-ii) (1999), pages 27-46.

\section{Theses and Dissertations}

Bacon, Elizabeth Emaline. 1951. The Hazara Mongols of Afghanistan: a study in social organization. Thesis (Ph. D.)--University of California.

Creasy, Jennifer Ruth. 2009. The religious identity of the Hazaras of Afghanistan and modern day Pakistan. Master’s thesis, University of Glasgow. Download PDF.

Harpviken, Kristian Berg. 1995. Political mobilisation among the Hazara of Afghanistan. Thesis (Cand. polit.)--University of Oslo.

Hussain, Mohammad. 2003. The Hazaras of Afghanistan: a study of ethnic relations. Thesis (M.A.)--McGill University.

Sarabi, Humayun. 2006. Politics and Modern History of Hazara Sectarian Politics in Afghanistan. MA Thesis, Tufts University. Download PDF.

\subsection{Uzbek}

\section{$\underline{\text { Books }}$}

Baldauf, Ingeborg. 1989. Materialien zum Volkslied der Ozbeken Afghanistans. Emsdetten: A. Gehling.

Jarring, G. 1938. Uzbek texts from Afghan Turkestan, with glossary. C. W. K. Gleerup.

Jarring, Gunnar. 1939. On the Distribution of Turk Tribes in Afghanistan: An Attempt at Preliminary Classification. Lund/Leipzig: C.W.K. Gleerup/Otto Harrassowitz.

Khashimbekov, Khadiya. 1994. Uzbeki Severnogo Afganistana. Moscow: Nauka.

\section{$\underline{\text { Articles, reports and book chapters }}$}

Centlivres, Pierre. 1975. ‘Les Uzbeks du Qattaghan’, Afghanistan Journal, 2(1).

Dupree, Louis. 1978. 'Uzbeks (Afghanistan)', in Richard V. Weeks (editor), Muslim Peoples: A World Ethnographic Survey. Westport, CT and London: Greenwood Press. 
Dupree, L. 1966/1970. ‘Aq Kupruk: A Town in North Afghanistan’, 2 parts, American University Field Staff (AUFS), Fieldstaff Reports 10/9-10, Hanover, N. H., 1966; repr. in Peoples and Cultures of the Middle East, ed. L. Sweet, II, New York, 1970, pp. 344-87.

Giustozzi, Antonio. 2005. 'The Ethnicisation of an Afghan Faction: Junbesh-I-Milli from its Origins to the Presidential Elections', Crisis States Programme Working Paper, No. 67. Crisis States Research Center. Download PDF.

Jarring, Gunnar. 1939. 'An Uzbek’s View of his Hometown and its Circumstances', Ethnos, No. 2: pp. 73-80.

Montgomery, David C. 1979. 'The Uzbeks in Two States: Soviet and Afghan Policies Toward an Ethnic Minority’, in William O. McCagg, Jr. and Brian D. Silver (editors) Soviet Asian Ethnic Frontiers. New York: Pergamon Press.

Minorities at Risk. 2003. 'Assessment for Uzbeks in Afghanistan', Minorities at Risk Project, December 31, 2003. Read online.

Naby, Eden. 1984. 'The Uzbeks in Afghanistan’, in Central Asian Survey, Vol.3, No.1.

Rasuly-Paleczek, Gabriele. 2010. 'Alignment Politics and Factionalism among the Uzbeks of North-Eastern Afghanistan', in Ethnicity, Authority, and Power in Central Asia: New Games Great and Small. Edited by Robert L. Canfield and Gabriele RasulyPaleczek. Routledge.

Rasuly-Paleczek, Gabriele. 2004. 'Frontiers, Hinterlands, Centers, Peripheries: Adapting to Changing Fortunes - the Uzbeks of Afghanistan', in Central Asia on Display: Edited by Gabriele Rasuly-Paleczek and Julia Katschnig. Vienna: LIT Verlag.

Rasuly-Paleczek, Gabriele. 2001. 'The Struggle for the Afghan State: Centralization, Nationalism and their Discontents', in Willem Van Schendel and Erik J. Zurcher (editors) Identity Politics in Central Asia and the Muslim World. I.B. Tauris.

Rasuly-Paleczek, Gabriele. 1998. 'Ethnic Identity versus Nationalism: The Uzbeks of North-Eastern Afghanistan and the Afghan State', in Touraj Atabaki and John O'Kane (editors), Post-Soviet Central Asia. London: Tauris Academic Studies.

Rasuly-Paleczek, Gabriele. 1994. 'Kinship and politics among the Uzbeks of northeastern Afghanistan’, in Ingeborg Baldauf and Michael Friederich (editors), Bamberger Zentralstudien. Konferenzakten ESCAS IV Bamberg 8-12 Oktober 1991 (Islamkundliche Untersuchungen 185): 11-27.

Shalinsky, Audrey C. 1990. 'The significance of Islam in pre-1978 Northern Afghanistan: An Urban Uzbek example’, Central Asian Survey, Volume 9, Issue 4, pp. 99 - 108. 
Shalinsky, Audrey C. 1986. 'Uzbak ethnicity in northern Afghanistan', in Erwin Orywal (editor), Die Ethnischen Gruppen Afghanistans. Wiesbaden.

Shalinsky, Audrey C. 1982. 'Islam and Ethnicity: The Northern Afghan Perspective', Central Asian Survey, Vol. 1, No. 2/3 (November 1982), pp. 71-84.

Shalinsky, Audrey C. 1980. 'Group Prestige in Northern Afghanistan: The Case of an Interethnic Wedding’ Ethnic Groups, Vol. 2, No. 4, pp. 269-282.

Tapper, Nancy. 1983. 'Acculturation in Afghan Turkistan: Pashtun and Uzbek women', Asian Affairs, Volume 14, Issue 1 February 1983 , pages 35 - 44.

\section{Theses and Dissertations}

Bleuer, Christian. 2007. Uzbeks Versus The Center: Mobilization as an Ethnic Minority in the Tajikistan and Afghanistan Civil Wars. MA Thesis, Central Eurasian Studies Department, Indiana University. Download PDF.

\subsection{Turkmen}

\section{$\underline{\text { Books }}$}

Babaeva, Aina, B. V. Kurtgel'deva, and Kh. A. Ataev. 1994. Turkmeny Afganistana: istoriko etnograficheskii ocherk. Ashgabat, Turkmenistan: Ylym.

Babaeva, Aina. 1992. Turkmeny Afganistana. Ashgabat, Turkmenistan: Bilim.

Jarring, Gunnar. 1939. On the Distribution of Turk Tribes in Afghanistan: An Attempt at Preliminary Classification. Lund/Leipzig: C.W.K. Gleerup/Otto Harrassowitz.

\section{$\underline{\text { Articles, reports, and book chapters }}$}

Babaeva, Aina. 1984. 'Turkmeny severo-zapadnogo Afganistan: k voprose o resselenii turkmenskikh piemen’, in Afganistan: ekonomika, politika, istoriia. Moscow: Nauka.

Dupaigne, Bernard. 1978. 'Une farce turkmène d'Afghanistan: comment on marie les jeunes gens’, p. 201-209, in : Quand le crible était dans la paille. Hommage à Pertev Naïli Boratav, Paris, Maisonneuve et Larose.

Dupaigne, Bernard. 1978 'Le grand art décoratif des Turkmènes', Paris, Objets et Mondes, XVIII, 1-2, printemps-été 1978, p. 3-30, biblio., 41 ph. n. et bl., 1 ph. couleur, couverture couleur. 
Dupaigne, Bernard. 1979. L'art populaire de Turkménie. Catalogue, Association FranceURSS - Musée de l’Homme, 9 mai-30 septembre 1979, 33 p.

Dupaigne, Bernard. 1986 'Le mariage chez les Turkmènes d’Afghanistan', p. 44-45, in : Côté Femmes, Laboratoire d’Ethnologie, musée de l’Homme.

Franz, Erhard. 1972. 'Ethnographische Skizzen zur Lage der Turkmenen in Afghanistan', Orient, 14(4), pages 175-184.

Franz, Erhard. 1972. 'Zur gegenwatigen verbreitung und Gruppierung der Turkmenen in Afghanistan’, Baessler Archiv. Neue Folge 20, pages 191-241.

Franz, Erhard. 1971. 'Die Turkmenen Afghanistans: Eine Feldforschung in AfghanischTurkestan im Jahre 1970’, Sociologus, 21(2), pages 184-7.

Irons, William G. 1978. 'Turkmen', in Richard V. Weeks (editor), Muslim Peoples: A World Ethnographic Survey. Westport, CT and London: Greenwood Press.

de Planhol, X. 1973. 'Sur la frontière turkmène de l’Afghanistan', Revue géographique de l'Est’, Vol. 13, No. 1-2, pp. 1-16.

Stucki, A. 1978. 'Horses and women. Some thoughts on the life cycle of Ersari Türkmen women’, Afghanistan Journal, Vol. 5, Issue 4, pp. 140-149.

Stucki, A. 1978. ‘Unter Turkmenen’, Tages Anzeiger Magazin, Vol. 44, pp. 6-13.

\section{Theses and Dissertations}

Liechti-Stucki, Anna Elisabeth. 1991. The Ersari Türkmen of Afghanistan: some aspects of social and economic organization and change in a central Asian Türkic society. PhD dissertation, Australian National University.

\subsection{Nuristani}

\section{Books}

Cacopardo, Alberto M. and Ruth Laila Schmidt (2006) (eds.): My Heartrendingly Tragic Story. ShaikhMuhammad Abdullah Khan 'Azar'. Oslo.

Edelberg, Lennart. 1984. Nuristani Buildings. Aarhus.

Edelberg, Lennart, and Schuyler Jones. 1979. Nuristan. Graz: Akademische Druck- u. 
Frembgen, Jurgen. 1983. Religiose Funktionstrager in Nuristan. Sankt Augustin: VGH.

Jettmar, Karl. 1975. Die Religionen des Hindukusch. Stuttgart

Jettmar, Karl. 1986. The Religions of the Hindukush. Vol. 1: The Religion of the Kafirs. London (revised translation of Jettmar 1975), pp. 155-202

Jones, Schuyler. 1966/1969. An Annotated Bibliography of Nuristan (Kafiristan) and the Kalash Kafirs of Chitral. 2 parts, Copenhagen.

Jones, Schuyler. 1967. The Political Organization of the Kam Kafirs: A Preliminary Analysis. Copenhagen: The Royal Danish Academy of Science and Letters.

Jones, Schuyler. 1974. Men of Influence in Nuristan. Seminar Press.

Klimburg, Max 1999. The Kafirs of the Hindu Kush: Art and Society of the Waigal and Ashkun Kafirs. Wiesbaden: Franz Steiner Verlag.

Robertson, George Scott. 1896. The Kafirs of the Hindu-Kush. London.

Scheibe, Arnold (ed.) 1937. Deutsche im Hindukusch. Bericht der Deutschen Hindukusch-Expedition 1935 der Deutschen Forschungsgemeinschaft. Berlin.

Snoy, Peter. 1962. Die Kafiren. Formen der Wirtschaft und geistigen Kultur. Frankfurt.

\section{$\underline{\text { Articles, reports, and book chapters }}$}

Buddruss, Georg. 1960. 'Zur Mythologie der Prasun-Kafiren’, Paideuma 7, pp. 200-209.

Buddruss, Georg. 1974. 'Some Reflections on a Kafir Myth', in Karl Jettmar and Lennart Edelberg (eds.), Cultures of the Hindukush. Selected Papers from the Hindu-Kush Cultural Conference held at Moesgård, 1970, Wiesbaden, pp. 31-6.

Buddruss, Georg. 1987 'Ein Ordal der Waigal-Kafiren des Hindukusch’, Cahiers Ferdinand de Saussure, 41, 1987, pp. 31 - 43.

de Bures, Alain. (n.d.). 'Historique de la succession de con its qui opposent les communaute's de Koustoz et de Kamdesh au Nouristan-est et qui a abouti a` la destruction des quatre villages de Koustoz’, Unpublished manuscript, MADERA.

Degener, Almuth. 2001. 'Hunters' Lore in Nuristan', Asian Folklore Studies, Volume 60. 
Dupaigne, Bernard. 2001. 'Kafiristan o los descendientes de Alejandro', p. 68-77, 5 ph. ; El Nuristan, p. 184-185 ; notices, in : Afganistan, una historia milenaria, Barcelone, Fundacion "la Caixa", 206 p.

Dupaigne, Bernard. 2002. 'Le Kafiristan ou les descendants d’Alexandre', p. 68-77, 5 ph. ; Le Nuristan, p. 182-183 ; notices, in : Afghanistan, une histoire millénaire, Paris, Réunion des Musées Nationaux - Musée Guimet, 206 p.

Dupree, Louis. 1978. 'Nuristani', in Richard V. Weeks (editor), Muslim Peoples: A World Ethnographic Survey. Westport, CT and London: Greenwood Press. Edelberg, Lennart. 1960. 'Statues de bois rapportées du Kafiristan à Kabul après la conquête de cette province par l'Emir Abdul Rahman en 1895/96', Arts Asiatiques 7(4).

Edelberg, L. 1965. 'Nuristanske Sølvpokaler’, Kuml Yearbook for the Jutland(?) Archaeological Society, Aarhus 1965, pp. 153 - 201.

Jones, Schuyler. 1974. Nuristan: Mountain Communities in the Hindu Kush', Afghan Studies, Vol. 1, pp. 77-90.

Jones, Schuyler. 1974. 'Kalashum Political Organization', in K. Jettmar and L.Edelberg, eds., Cultures of the Hindukush. Wiesbaden.

Katz, David J. 1984. 'Responses to Central Authority in Nuristan: the case of the Vaygal Valley Kalasha', in Revolutions and Rebellions in Afghanistan. M. Nazif Shahrani and Robert L. Canfield (editors). Berkeley, California: Institute of International Studies.

Klimburg, Max. 2004. 'Nuristan’, in Encyclopedia Iranica. Read online.

Klimburg, Max. 2004. 'The Arts and Societies of the Kafirs of the Hindu Kush', Central Asian Affairs 35.3: 365-386.

Klimburg, Max. 2002. 'The Arts and Culture of Parun, Kafiristan's "Sacred Valley"', Arts Asiatiques 57: 51-68.

Klimburg, Max. 2001. 'The situation in Nuristan', Central Asian Survey, 20(3): 383-390.

Klimburg, Max. 2001. 'The present situation in Nuristan', in C. Noelle et al (editors), Afghanistan - A Country without a State? Frankfurt am Main.

Klimburg, Max. (n.d.) 'Between Myth and Reality: How Legendary Kafiristan became Nuristan,' Fikrun wa Fann (Art and Thought) Vol. 78.

Klimburg, Max. 1990. ‘Kulturformen bei den Kafiren des Hindukusch’, in Mitteilungen der Berliner Gesellschaft für Anthropologie, Ethnologie und Urgeschichte, vol. 11. 
Ovesen, Jan. 1983. 'The Construction of Ethnic Identities: The Nuristani and Pashai of Eastern Afghanistan', in Identity: Personal and Socio-Cultural, edited by Anita Jacobsen-Widding. Uppsala; Acta Universitatis Upsaliensis, pp. 321-333.

Ovesen, J. 1986. 'The construction of ethnic identities: the Nurestani and Pashai', in Die ethnischen Gruppen Afghanistans: Fallstudien zu Gruppenidentitat un Intergruppenbeziehungen. E. Orywal (editor). Wiesbaden: Reichert. Pages 239-253.

Palwal, A.R. 1968-71. 'History of the Former Kafiristan, parts I-VII', Afghanistan (Kabul), Vol. 21-24.

Parkes, Peter. 1987. 'Livestock Symbolism and Pastoral Ideology Among the Kafirs of the Hindu Kush’, Man, New Series, Vol. 22, No. 4, (Dec., 1987), pp. 637-660.

Sarianidi, V. 1999. 'Near Eastern Aryans in Central Asia', Journal of Indo-European Studies, 27.3-4: 295-326.

Snoy, P. 1965. 'Nuristan und Munğan', Tribus, Vol. 14, pp. 101-49.

Strand, Richard. 2006. ‘Topics in Vâsi Ethnography by Zaman Xân.’ Read online.

Strand, Richard F. 2003-07. 'The Current Political Situation in Nuristan', Richard Strand's Nuristan Site. Read Online.

Strand, Richard F. 1984 'The Evolution of Anti-Communist Resistance in Eastern Nuristan,' in Revolutions and Rebellions in Afghanistan. M. Nazif Shahrani and Robert L. Canfield (editors), pages 77-93. Berkeley, California: Institute of International Studies.

Strand, Richard F. 1984. 'Nuristanis', in Muslim Peoples. (2 ${ }^{\text {nd }}$ Edition), ed. Richard V. Weekes, 2: 569-574. Westport, Connecticut: Greenwood Press.

Strand, Richard F. 1975. 'The Changing Herding Economy of the Kom Nuristani', Afghanistan Journal, Vol. 2, No. 4, Graz.

Strand, Richard F. 1974. 'A Note on Rank, Political Leadership and Government among the Pre-Islamic Kom', in K. Jettmar and L.Edelberg, eds., Cultures of the Hindukush. Wiesbaden, pp. $57-63$.

Strand, Richard F. 1974. 'Principles of Kinship Organization among the Kom Nuristani', in K. Jettmar and L.Edelberg, eds., Cultures of the Hindukush. Wiesbaden.

\section{Dissertations and Theses}

Brillet, Marie. 1998. 'Study of the socio-political organisation and identification of village organisations in the Wama-Parun valley (Nuristan, Afghanistan)', Unpublished MA thesis. Paris, Universite Paris I (Institut d'Etude du Developpement ) and MADERA. 
Jones, Schuyler. 1971. Kalashum political organization: a study of village government in Waigal Valley, Nuristan. Thesis (D. Phil.)--University of Oxford.

Katz, David J. 1982. Kafir to Afghan: Religious Conversion, Political Incorporation, and Ethnicity in the Vaigal Valley, Nuristan. Ph.D. Dissertation, University of California.

Keiser, R. Lincoln. 1971. Social Structure and Social Control in Two Afghan Mountain Societies. Ph.D. Dissertation, University of Rochester.

Nuristani, Ahmad Yusuf. 1992. Emergence of Ulama as Political Leaders in the Waigal Valley: The Intensification of Islamic Identity. Ph.D. Dissertation, University of Arizona.

Snoy, Peter. 1962. Die Kafiren: Formen der Wirtschaft und geistigen Kultur. [Germany : s.n.], 1962 (Giessen : Chemoprint). Thesis (doctoral)--Johann Wolfgang GoetheUniversität, Frankfurt am Main, 1962.

\subsection{Tajik}

\section{Books}

Makhmadshoev, Rakhmatsho. 2001. Tadzhiki Afganistana v novoe vremya: ocherki istorii khozyaistva I materialnoi kultury. Dushanbe, Tajikistan: Donish.

Poulton, Michelle and Robin Poulton. 1979. Ri Jang: un village tajik dans le nord de l'Afghanistan: traditions sociales et économiques face au développement. Paris: Selfpublished. (3 Volumes).

Sa’di, S. 1995. Mukhtasari ta'rikhi siyosii Tojikoni Afghanistan. Dushanbe: Oli Somon.

\section{$\underline{\text { Articles, reports and book chapters }}$}

Allan, N. 1974. 'The Modernization of Rural Afghanistan: A Case Study', in Afghanistan in the 1970s, ed. L. Dupree and L. Albert, New York, pp. 113-25.

Balland, D. 1974. 'Vieux sédentaire tadjik, les immigrants Pachtoun dans le sillon de Ghazni (Afghanistan oriental)', Bulletin de l'Assoc, des géographes français, Vol. 51.

Beattie, H. 1982. Kinship and Ethnicity in the Nahrin Area of Northern Afghanistan Afghan Studies, Vol. 3-4, pp. 39-51.

Centlivres, Pierre and Micheline Centlivres-Demont. 1998. 'Tajikistan and Afghanistan: the ethnic groups on either side of the border' in Tajikistan: the Trials of Independence. Mohammad-Reza Djalili, F. Grare and Shirin Akiner (editors). Richmond: Curzon. 
Dorronsoro, Gilles. 1994. 'Politique et ethnicite en Afghanistan: le cas Tadjik,' CEMOTI, 18 (1994), pages 131-147.

Dupree, Louis. 1978. 'Tajik', in Richard V. Weeks (editor), Muslim Peoples: A World Ethnographic Survey. Westport, CT and London: Greenwood Press.

Dupree, L. 1966/1970. ‘Aq Kupruk: A Town in North Afghanistan’, 2 parts, American University Field Staff (AUFS), Fieldstaff Reports 10/9-10, Hanover, N. H., 1966; repr. in Peoples and Cultures of the Middle East, ed. L. Sweet, II, New York, 1970, pp. 344-87.

Janata, A. 1986. 'Aimaq und Tagik in West-Afganistan', in Die ethnischen Gruppen Afghanistans: Fallstudien zu Gruppenidentitat un Intergruppenbezienhungen. E. Orywal (editor). Wiesbaden: Reichert. Pages 87-100.

Kussmaul, F. 1965. 'Siedlung und Gehöft bei den Tağiken in den Bergländern Afghanistans’, Anthropos, Vol. 60, pp. 487-532.

Kussmaul, F. 1965. ‘Badaxšan und seine Tağiken’, Tribus, Vol. 14, pp. 711-99.

Sawez, Islamuddin. 1986. 'Anpassung und Abgrenzung - die Tagik,' in Die ethnischen Gruppen Afghanistans: Fallstudien zu Gruppenidentitat un Intergruppenbezienhungen. E. Orywal (editor). Wiesbaden: Reichert. Pages 284-289.

Uberoi, J. 1971. 'Men, Women and Property in Northern Afghanistan', India and Contemporary Islam, ed. S. Lokhandwall, Simla, pp. 388-416.

\section{$\underline{\text { Dissertations }}$}

Poulton, Michelle. 1979. Un Village tajik dans le nord de l'Afghanistan : traditions sociales et économiques face au développement. Dissertation: Thèse 3ème cycle Sciences sociales du développement, Paris, E.H.E.S .S.

Uberoi, J.P.S. 1964. Social Organisation of the Tajiks of Andarab Valley, Afghanistan. PhD dissertation, Australian National University.

\subsection{Baluch}

\section{$\underline{\text { Books }}$}

Gafferberg, E. 1975. Perezhitki religioznykh predstavleniǐ u Beludzheǐ. Moscow. 
Hughes, A. W. 2007. The Country of Balochistan: Its Geography, Topography, Ethnology, and History. London: Elibron Classics. Unabridged reprint from 1877.

Orywal, E. 1982. Die Baluc in Afghanisch-Sistan: Wirschaft und Sozio-politische Organization in Nimruz, SW- Afghanistan. Berlin: Reimer.

Pehrson R. and F. Barth. 1966. The Social Organization of the Marri Baluch. Chicago.

Salzman, Phillip Carl. 2000. The Black Tents of Baluchistan. Washington and London: Smithsonian Institution Press.

Wirsing, R.G. 1981. The Baluchis and Pathans. London: Minority Rights Group.

\section{$\underline{\text { Articles, reports and book chapters }}$}

Ahmed, Akbar. 1980. 'The impact of Afghan refuges on ethnicity and politics in Baluchistan’, Central Asian Survey, 9(3).

Balland, D. \& Benoist, A. 1982. 'Nomades et semi-nomades Baluc d'Afghanistan', Revue Geographic de l’Est, 22 (1982), pages 117-144.

Boyajian, Vahe. 2000. ‘On Baluchi Separatism’, Iran and Caucasus, 3-4.

Jetly, Rajshree. 2004. 'Baluch ethnicity and nationalism (1971-81): an assessment', Asian Ethnicity, Vol. 5, Issue 1.

Orywal, Erwin. 2006. 'Krieg und Kampf in Afghanistan', in B. Chiari (Hg.), Wegweiser zur Geschichte Afghanistans. Militärgeschichtliches Forschungsamt, Schöningh.

Orywal, E. 1996. 'Periphery and identity: processes of detribalization among the Baloch of Afghanistan', in Marginality and Modernity: Ethnicity and Change in Post-colonial Balochistan. Paul Titus (editor). Karachi: Oxford University Press. Pages 78-102.

Orywal, Erwin. 1986. 'Qaum-e Baluch: Ideologie und Realität’, In: E. Orywal (Hg.), Die ethnischen Gruppen Afghanistans. Fallstudien zu Gruppenidentität und Intergruppenbeziehungen. Beihefte zum Tübinger Atlas des Vorderen Orients (TAVO), Reihe B, Nr. 70, Wiesbaden, Dr. Ludwig Reichert Verlag: 223-238.

Orywal, Erwin. 1985. 'Baluch Ethnicity in Afghanistan', Newsletter of Baluchistan Studies, 2: 40-53.

Pastner, Stephen L. 1978. 'Baluch', in Richard V. Weeks (editor), Muslim Peoples: A World Ethnographic Survey. Westport, CT and London: Greenwood Press.

Titus, P. and N. Swidler. 2000. 'Knights, not Pawns: ethno-nationalism and regional dynamics in post-colonial Balochistan’, Int. Jour. of Middle Eastern Studies, 32(1). 


\section{Dissertations and Theses}

Orywal, Erwin. 1982. Die Baluch in Afghanisch-Sistan. Wirtschaft und sozio-politische Organisation in Nimruz, SW-Afghanistan. Kölner Ethnologische Studien, 4, Berlin: Reimer Verlag (Dissertation).

\subsection{Pashai}

\section{Books}

Snoy, P 1975. Bagrot, Eine dardische Talschaft im Karakorum. Graz.

Wutt, K. 1981. Pashai: Landschaften - Menschen - Architektur. Graz: Akademische Druck- u. Verlagsanstalt.

\section{Articles, reports, and book chapters}

Catu, R. 1995. 'Le peuple Pashai’, Central Asian Survey, 14(3), pages 449-461.

Emadi, Hafizullah. 2000. 'Praxis of taqiyya: perseverance of Pashaye Ismaili enclave, Nangarhar, Afghanistan’, Central Asian Survey, 19(2), pp. 253-264.

Keiser, R. L. 1975. 'Genealogical Beliefs and Social Structure among the Sum of Afghanistan’, Afghanistan Council, Asia Society, Occasional Paper, 5.

Keiser, R. L. 1974. "Social Structure in the Southeastern Hindu Kush: Some Implications for Pashai Ethno-history,” Anthropos, Vol. 69, pp. 445-56.

Ovesen, J. 1988. ‘A Local Perspective in the Incipient Resistance in Afghanistan', in The Tragedy of Afghanistan. Edited by Bo Huldt and Erland Jannson. London: Croom Helm.

Ovesen, J. 1986. 'The construction of ethnic identities: the Nurestani and Pashai', in Die ethnischen Gruppen Afghanistans: Fallstudien zu Gruppenidentitat un Intergruppenbeziehungen. E. Orywal (editor). Wiesbaden: Reichert. Pages 239-253.

Ovesen, J. 1984. 'On the cultural heritage of the Pashai', Anthropos, 79, pages 87-98.

Ovesen, Jan. 1983. 'The Construction of Ethnic Identities: The Nuristani and Pashai of Eastern Afghanistan', in Identity: Personal and Socio-Cultural, edited by Anita Jacobsen-Widding. Uppsala; Acta Universitatis Upsaliensis, pp. 321-333. 
Ovesen, J. 1983. 'Environment and history in Pashai world-view', Folk, 25, pages 167-84.

Ovesen, J. 1982. 'Marriage and social groupings among the Pashai', Folk, 24.

Ovesen, J. 1981. 'The continuity of Pashai society', Folk, 23, pages 221-234.

Wutt, K. 1986. 'The Pashai in Darra-i Mazar and Wamagal', in Die ethnischen Gruppen Afghanistans: Fallstudien zu Gruppenidentitat un Intergruppenbeziehungen. E. Orywal (editor). Wiesbaden: Reichert. Pages 304-308.

Wutt, K. 1978. 'Über Herkunft und kulturelle Merkmale einiger Pashai-Gruppen', Afghanistan Journal, Vol. 5, Issue 2, pp. 43-58.

\section{Dissertations and Theses}

Keiser, R. Lincoln. 1971. Social Structure and Social Control in Two Afghan Mountain Societies. Ph.D. Dissertation, University of Rochester.

\subsection{Other or Various Ethnic Groups}

\section{$\underline{\text { Books }}$}

Andreev, M. 1927. Po etnografii Afganistana. Tashkent.

Andreev, M. 1932. Po etnologii Afganistana. Tashkent.

Barfield, Thomas. 1981. The Central Asian Arabs of Afghanistan. U of Texas Press.

Charpentier, Carl-Johan. 1972. Bazaar-e Tashqurghan: ethnological studies in an Afghan traditional bazaar. Studia ethnographica upsaliensia, 36. Uppsala: Uppsala Universitetet, Institutionen för Allmän och Jämförande Etnografi; London: Kegan Paul.

Dor, R. and C. Naumann. 1978. Die Kirghisen des afghanischen Pamir. Graz, 1978.

Dor, R. 1975. Contribution à l'étude des Kirghiz du Pamir Afghan. (Cahiers Turcica 1).

de Grancy, R. and R. Kostka, ed., Grosser Pamir, Graz, 1975

Gratzl, K. 1974. ed., Hindukusch, Graz.

Kreutzmann, Hermann. 1996. Ethnizität im Entwicklungsprozess: die Wakhi in Hochasien. Berlin: Reimer. 
Mandersloot G. and J. Powell. 1971. Firozkohi een Afghanistan Reisjournal. Rotterdam.

Rao, Aparna. 1982. Les Gorbat d'Afghanistan: aspects économiques d'un groupe itinérant "Jat." Paris : Ed. Recherche sur les civilizations.

Rashidov, R. T. 1977. Ǎmmaki. Tashkent: Fan.

Shahrani, M. Nazif. 2002/1979. The Kirghiz and Wakhi of Afghanistan: Adaptation to Closed Frontiers and War. Seattle: University of Washington Press.

Schurman, H.F. 1962. The Mongols of Afghanistan: An Ethnography of the Mongols and Related Peoples of Afghanistan. The Hague: Mouton.

\section{$\underline{\text { Articles, reports, and book chapters }}$}

Anderson, Jon W. 1987. 'Ethnic dilemmas in Iran, Pakistan and Afghanistan', in Soviet-American Relations with Pakistan, Iran and Afghanistan. Hafeez Malik, ed. London: Macmillan.

Anderson, Jon W. 1978. 'Introduction', in Ethnic Processes \& Intergroup Relations in Contemporary Afghanistan. Edited by Jon W. Anderson \& Richard F. Strand. New York: The Asia Society.

Baldauf, Ingeborg. 2007. 'The Dayi Kargil of Andkhoy: Language, History and Profession in Local Identity Discourses', Asien, 104. Download PDF.

Balland, Daniel. 1991. 'Tents, yurts, huts and caves: on the cultural geography of temporary dwellings in Afghanistan', Folk, Vol. 33, p. 107-115.

Balland, Daniel. 1988. 'Nomadic Pastoralists and Sedentary Hosts in the Central and Western Mountains, Afghanistan', in Ethnic Processes and Intergroup Relations in Contemporary Afghanistan, edited by Jon W. Anderson and Richard F. Strand. New York: Afghanistan Council of the Asia Society, pp. 26-34.

Callahan, Ted. n.d. 'The Kyrgyz of the Afghan Pamir Ride On', American-University in Central Asia. Download PDF.

Centlivres, Pierre. 1976. L'Histoire recente de L'Afghanistan et la configuration ethnique des provinces du nord-est', Studia Iranica 5: pp. 255-267.

Centlivres, Pierre. 1979. 'Groupes ethniques: de 'heterogeneite d'un concept aux ambiguites de la representation. L'example afghan', in Beitrage zur Kulturgeographie des islamischen Orients, edited by Eckhart Ehlers. Marburg/Lahn: Universitat Marburg. 
Centlivres-Demont, Micheline. 1976. 'Types d'occupation et relations interethnique dans le Nord-Est de l’Afghanistan’, Studia Iranica 5: pp. 269-277.

Dupaigne, Bernard. 1976. 'Yourtes de jeunes mariés dans le nord de l'Afghanistan', p. 49-54, in : Études Turques, vol. 1, Actes du XXIX Congrès International des Orientalistes, Paris, L’Asiathèque.

Dupaigne, Bernard. 1979. 'Le dernier jour des hommes; enterrements de première classe et enterrements de dernière classe en Afghanistan’, p. 208-219, in : Les hommes et la mort. Rituels funéraires à travers le monde, Le Sycomore-Objets et Mondes.

Dupaigne, Bernard. 1980. 'Les Fêtes en Afghanistan’, p. 169-176, 5 ph., in : Fêtes du Monde. Asie, Paris, éd. du Moniteur.

Dupaigne, Bernard. 1983 'Les Arabes arabophones d’Afghanistan', p. 89-96, in : Le cuisinier et le philosophe. Hommage à Maxime Rodinson, Paris, G.P. Maisonneuve et Larose, déc. 1983.

Dupaigne, Bernard. 1983. 'Femmes mariées pour petites filles: les poupées en Afghanistan’, p. 103-105, in : Poupée-jouet, poupée-reflet, Paris, Muséum National d'Histoire Naturelle.

Dupaigne, Bernard. 1984. 'Les peuples d’Afghanistan', p. 27-55, 10 ph., in : Afghanistan, la colonisation impossible, Paris, Éd. du Cerf, 274 p.

Dupaigne, Bernard. 1988. 'Lieux et formes du pouvoir en Afghanistan, hier et aujourd'hui', p. 56-70, Oxford, Central Asian Survey, Society for Central Asian Studies, Pergamon Press, VII, 2-3.

Dupaigne, Bernard. 1997. 'Un exorciste en Afghanistan. Chamanisme ou non ? (en hollandais)', p. 116-127, 5 ph. n. et bl., 4 ph. coul., in : Wat Bezielt de Sjamaan ? Genezing, Extase, Kunst, Amsterdam, Koninklijk Institut voor de Tropen.

Dupaigne, Bernard. 2000. 'La femme dans l'économie rurale’, p. 19-31, in : La femme afghane à travers l'histoire de l'Afghanistan, Actes du colloque UNESCO, Paris, 11 décembre 1998, Paris, CEREDAF-UNESCO, 104 p.

Dupaigne, Bernard. 2001. 'Nomades d'Asie Centrale’, p. 61-67, in : Afghanistan, la mémoire assassinée, Paris, Mille et une nuits, 144 p.

Dupree, Louis. 1978. 'Qizilbash', in Richard V. Weeks (editor), Muslim Peoples: A World Ethnographic Survey. Westport, CT and London: Greenwood Press.

Dupree, L 1962. 'The Indian Merchants in Kabul', AUFS Fieldstaff Reports, South Asia Series 6/3. 
Emadi, Hafizullah. 2005. 'Nahzat-e-Nawin: modernization of the Badakhshani Isma'ili communities of Afghanistan’, Central Asian Survey, 24(2), pp. 165-189.

Emadi, Hafizullah. 1993. 'Minority group politics: the role of Ismailis in Afghanistan's politics’, Central Asian Survey, 12(3), pages 379-392.

English, P. 1973. 'The Pre-industrial City of Heart', in Cities in the Middle East, ed. L. Brown, Princeton.

Farhadi, R. 1969. 'Die Sprachen von Afghanistan', Zentralasiatische Studien, Vol. 3.

Gawecki, Marek. 1986. 'Structure and organization of the rural communities of central and northern Afghanistan’, Ethnologia Polona, Vol. 12, pages 7-35.

Hahn, H. 1964. Die Stadt Kabul (Afghanistan) und ihr Umland (Bonner Geographische Abhandlungen 34, 35), 1964, 1965.

Homam, S. 1980. “Afghan Moghols,” Afghanistan 33/1-2, 1980.

Janata, A. 1986. 'Aimaq und Tagik in West-Afganistan', in Die ethnischen Gruppen Afghanistans: Fallstudien zu Gruppenidentitat un Intergruppenbezienhungen. E. Orywal (editor). Wiesbaden: Reichert. Pages 87-100.

Janata, Alfred. 1978. 'Aimaq', in Richard V. Weeks (editor), Muslim Peoples: A World Ethnographic Survey. Westport, CT and London: Greenwood Press.

Kreutzmann, Hermann. 2003. 'Ethnic minorities and marginality in the Pamirian Knot: Survival of Wakhi and Kyrgyz in a Harsh Environment and Global Contexts', The Geographical Journal, Vol. 169, No. 3, pp. 215-235.

Mariq, A. 1959. 'Arwitsch, un village mongole', Le minaret du Djam, Paris, pp. 77-78.

Newell, Richard S. 1989. 'Post-Soviet Afghanistan: The Position of Minorities', Asian Survey, Vol. 29, No. 11, pp. 1090-1108.

Olesen, Asta. 1987. 'Peddling in East Afghanistan: adaptive strategies of the peripatetic Sheikh Mohammadi', The other nomads: peripatetic minorities in cross cultural perspective. Ed. Aparna Rao. - Köln : Böhlau, pp. 35-63.

Olesen, A. 1985. 'The Sheikh Mohammadi - a marginal trading community in east Afghanistan’, Folk, 27, pages 115-146.

Olesen, A. 1982. 'The Musallis. The Graincleaners of East Afghanistan', Afghanistan Journal, Vol. 9, Issue 1, pp. 13-19. 
Rao, Aparna. 1988. 'Folk models and inter-ethnic relations in Afghanistan : a case study of some peripatetic communities', in Le fait ethnique en Iran et en Afghanistan. dir. Jean-Pierre Digard. Paris: Ed. du CNRS, pp. 109-120.

Rao, Aparna. 1988. 'How non-food producing nomads obtain their food : peripatetic strategies in Afghanistan', in Coping with uncertainty in food supply. Ed. by I. de Garine and G.A. Harrison. - Oxford : Clarendon Press, pp. 360-378.

Rao, Aparna. 1986. 'Peripatetic minorities in Afghanistan - Image and Identity', in Erwin Orywal (editor), Die Ethnischen Gruppen Afghanistans. Wiesbaden.

Rao, Aparna. 1986. 'Roles, status and niches: a comparison of peripatetic and pastoral women in Afghanistan', Nomadic Peoples, Vol. 21(2), p. 153-177.

Rao, A. 1982. 'Non-food-producing nomads and the problem of their classification; the case of the Ghorbat of Afghanistan', Eastern Anthropologist, 35, pages 115-134.

Rao, A. 1981. 'Qui sont les Jat d’Afghanistan?’, Afghanistan Journal, Vol. 8, pp. 55-64.

Rao, A. 1979. 'Note préliminaire sur les Jat d’Afghanistan’, Studia Iranica, Vol. 8.

Roy, Olivier. 1989. 'Qawm, tribus, ethnies et nationalités en Afghanistan', Afghanistan Info, No. 25.

Scott, Richard B. 1980. 'Tribal \& ethnic groups in the Helmand Valley', Occasional paper No. 21. (Asia Society. Afghanistan Council) New York. Download PDF.

Shahrani, M. Nazif. 1986. 'The Kirghiz Khans: Styles and Substance of Traditional Local Leadership in Central Asia', Central Asian Survey, 5(3/4): 255-271.

Shahrani, M. Nazif. 1981. 'Growing in Respect: Aging Among the Kirghiz of Afghanistan', In Other Ways of Growing Old. Edited by Pamela Amoss and Steven Harrell. Palo Alto: Stanford University Press, pp. 175-191.

Shahrani, M. Nazif. 1978. 'The Retention of Pastoralism Among the Kirghiz of the Afghan Pamirs', In Himalayan Anthropology: The Indo-Tibetan Interface. Edited by J.F. Fisher. The Hague, Mouton Publishers, pp. 233-250.

Shahrani, M. Nazif. 1976. 'Kirghiz Pastoralists of the Afghan Pamirs: An Ecological and Ethnographic Overview’, Folk, 18: pp. 129-143.

Shalinsky, Audrey. 'Group Prestige in Northern Afghanistan: The Case of an Interethnic Wedding’, Ethnic Groups, 1980 Vol. 2, pp. 269-282.

Slobin, Mark. 1976. Music in the Culture of Northern Afghanistan. Tucson: University of Arizona Press. PDF downloads link. 
Swidler, Nina. 1978. 'Brahui', in Richard V. Weeks (editor), Muslim Peoples: A World Ethnographic Survey. Westport, CT

Tani, Yutaka (ed). 1978/1980. Preliminary report of field survey on the agro-pastoral peoples in Afghanistan. Research Group for Comparative Studies on the Agro-Pastoral Peoples in Southwestern Eurasia, Research Institute for the Humanistic Studies. Kyoto

Tapper, Richard. 2008. 'Who are the Kuchi? Nomad self-identities in Afghanistan', Journal of the Royal Anthropological Institute, Vol. 14, pp. 97-116.

Wiebe, D. 1973. "Struktur und Funktion eines Serais in der Altstadt von Kabul," Schriften der Geographischen Instituts der Universität Kiel, 38, pp. 213-33.

\section{Theses and Dissertations}

Aharon, Sara. 2008. Afghani Jewry past and present: an examination of the Jewish community of Afghanistan and its relocation to the United States. Senior honors thesis-Brandeis University.

Baghban, H. The Content and Concept of Humor in Magadi Theater, PhD thesis, Indiana University.

Koplik, Sara Beth. 2003. The demise of the Jewish community in Afghanistan, 1933-1952. Thesis (Ph.D.)--University of London.

Nassimi, Azim M. 1997. An ethnography of political leaders in Afghanistan. Thesis (D. Ed.)--Ball State University.

Rao, Aparna. 1980, 1982. Les Gorbat d'Afghanistan: aspects économiques d'un groupe itinérant "Jat." Paris : Éditions Recherche sur les civilisations, 1982. Series (Bibliothèque iranienne / Institut français d'iranologie de Téhéran ; no 27) ( Mémoire ; no 14). Dissertation thesis _ Université de Paris-Sorbonne, 1980. 


\section{Conflict and Mobilization: War, Ethnicity, Jihad, Taliban, Factions, "Warlords," Etc... (1979- the present)}

\section{$\underline{\text { Academic Press Books }}$}

Abou Zahab, Mariam, and Olivier Roy. John King (translator). 2006. Islamist Networks: The Afghan-Pakistan Connection. New York: Columbia University Press.

Azoy, Whitney. 1982. Buzkashi: Game and Power in Afghanistan. Philadelphia: The University of Pennsylvania Press.

Banuazizi, Ali and Myron Weiner (Eds.) 1986. The State, Religion, and Ethnic Politics: Afghanistan, Iran, and Pakistan. Syracuse: Syracuse University Press.

Barfield, Thomas. 2010. Afghanistan: A Cultural and Political History. Princeton University Press.

Barry, Michael. 2006. A History of Modern Afghanistan. Cambridge University Press.

Bhatia, Michael Vinay and Mark Sedra. 2008. Afghanistan, Arms and Conflict: Armed Groups, Disarmament and Security in a Post-war Society. Routledge.

Canfield, Robert L. and Gabriele Rasuly-Paleczek (editors). 2010. Ethnicity, Authority, and Power in Central Asia: New Games Great and Small. Routledge.

Crews, Robert D. and Tarzi, Amin. 2008. The Taliban and the Crisis of Afghanistan. Harvard University Press.

Dorronsoro, Gilles. 2005. Revolution Unending: Afghanistan, 1979 to the Present. New York: Columbia University Press.

Edwards, David B. 2002. Before Taliban: Genealogies of the Afghan Jihad. Berkeley, CA: University of California Press.

Edwards, David B. 1996. Heroes of the Age: Moral Fault Lines on the Afghan Frontier. Berkeley, CA: University of California Press.

Emadi, Hafizullah. 2010. Dynamics of Political Development in Afghanistan: The British, Russian, and American Invasions. Palgrave Macmillan.

Ewans, Martin. 2005. Conflict in Afghanistan: Studies in Asymmetric Warfare. Routledge. 
Giustozzi, Antonio. 2009. Empires of Mud: Wars and Warlords of Afghanistan. Hurst/Columbia University Press.

Giustozzi, Antonio (ed.). 2009. Decoding the New Taliban: Insights from the Afghan Field. Hurst/Columbia University Press.

Giustozzi, Antonio. 2008. Koran, Kalashnikov and Laptop: The Neo-Taliban Insurgency in Afghanistan. New York: Columbia University Press.

Giustozzi, Antonio. 2001 Afghanistan's Endless War: State Failure, Regional Politics, and the Rise of the Taliban. Seattle: University of Washington Press.

Giustozzi, Antonio. 2000. War, Politics, and Society in Afghanistan: 1978-1992.

Washington: Georgetown University Press.

Gohari, M. J. 2001. The Taliban: Ascent to Power. Oxford, UK: Oxford University Press.

Goodson, Larry P. 2001. Afghanistan's Endless War: State Failure, Regional Politics, and the Rise of the Taliban. University of Washington Press.

Hopkins, Ben. 2008. The Makings of Modern Afghanistan. Palgrave Macmillan.

Hussain, Rizwan. 2005. Pakistan And The Emergence Of Islamic Militancy in Afghanistan. Ashgate publishing.

Johnson, Rob. 2011. The Afghan Way of War. Hurst/Columbia.

Jones, Seth. 2009. In the Graveyard of Empires: America's War in Afghanistan. W.W. Norton \& Co.

Kakar, Hassan. 1997. Afghanistan: The Soviet Invasion and the Afghan Response, 19791982. Berkeley, CA: University of California Press.

Loyn, David. 2009. In Afghanistan: Two Hundred Years of British, Russian and American Occupation. Palgrave Macmillan.

Maley, William. 2007. Rescuing Afghanistan. London: Hurst \& Company.

Maley, William. 2002. The Afghan Wars. New York: Palgrave Macmillan.

Maley, William (editor). 1998. Fundamentalism Reborn? Afghanistan and the Taliban. New York: New York University Press.

Malik, Hafeez. 2008. US Relations With Afghanistan and Pakistan: The Imperial Dimension. Oxford University Press. 
Matinuddin, Kamal. 2000. The Taliban Phenomenon: Afghanistan 1994-1997. Oxford UK: Oxford University Press.

Misdaq, Nabi. 2006. Afghanistan: Political Frailty and Foreign Interference. Routledge.

Misra, Amalendu. 2004. Afghanistan: The Labyrinth of Violence. Polity Press.

Noelle-Karimi, Christine and Conrad Schetter and Reinhard Schlagintweit (editors) 2002. Afghanistan - A Country without a State? Frankfurt am Main, Germany: IKO.

Orywal, Erwin. 1986. Ethnischen Gruppen Afghanistans: Fallstudien zu

Gruppenidentität und Intergruppenbeziehungen. Wiesbaden: L. Reichert.

Qassem, Ahmad Shayeq. 2009. Afghanistan's Political Stability: A Dream Unrealised. Ashgate publishing.

Rais, Rasul Bakhsh. 2008. Recovering the Frontier Stage: War, Ethnicity, and State in Afghanistan. Lexington Books.

Rais, Rasul Baksh. 1995. War Without Winners: Afghanistan's Uncertain Transition After the Cold War. Oxford, UK: Oxford University Press.

Rasanayagam, Angelo. 2003. Afghanistan: A Modern History. London: I. B. Tauris.

Roberts, Jeffrey J. 2003. The Origins of Conflict in Afghanistan. Westport, CT: Praeger.

Rashid, Ahmed. 2009. Descent into Chaos: The U.S. and the Disaster in Pakistan, Afghanistan, and Central Asia. Penguin.

Rashid, Ahmed. 2000. Taliban: Militant Islam, Oil, and Fundamentalism in Central Asia. New Haven, CT: Yale University Press.

Roy, Olivier. 1995. Afghanistan: From Holy War to Civil War. Princeton: Darwin Press.

Roy, Olivier. 1990. Islam and Resistance in Afghanistan. Cambridge University Press.

Rubin, Barnett R. and Jean-Frédéric Légaré-Tremblay. 2009. L'Afghanistan sur le point de bascule. Nota Bene.

Rubin, Barnett. 1995. The Search for Peace in Afghanistan: From Buffer State to Failed State. New Haven, CT: Yale University Press.

Rubin, Barnett. 1995. The Fragmentation of Afghanistan: State Formation and Collapse in the International System. New Haven, CT: Yale University Press. 
Rzehak, Lutz. (Hrsg.) 2004. Die Taliban im Land der Mittagssonne. Geschichten aus der afghanischen Provinz. Erinnerungen und Notizen von Abdurrahman Pahwal der Reihe Erinnerungen an Zentralasien. Reichert verlag.

Saikal, Amin. 2004. Modern Afghanistan: A History of Struggle and Survival. London: I. B. Tauris.

Schetter, C. 2003. Ethnizität und Ethnische Konflikte in Afghanistan. Berlin: Reimer

Semple, Michael. 2009. Reconciliation in Afghanistan. USIP Press.

Shahrani, M. Nazif and Robert L Canfield (Eds.) 1984. Revolutions and Rebellions in Afghanistan: Anthropological Perspectives. Berkeley, CA: Institute of International Studies, University of California Berkeley.

Sinno, Abdulkader. 2008. Organizations at War in Afghanistan and Beyond. Ithaca, NY: Cornell University Press.

Strick van Linschoten, Alex and Felix Kuehn. 2011. An Enemy We Created: The Myth of the Taliban / Al-Qaeda Merger in Afghanistan, 1970-2010. Hurst/Columbia University Press.

Urban, Mark. 1990. War in Afghanistan. London: Macmillan.

Weiner, Myron, and Ali Banuazizi (editors). 1993. The Politics of Social Transformation in Afghanistan, Iran, and Pakistan. Syracuse, NY: Syracuse University Press.

Zaeef, Abdul Salam. 2010. My Life with the Taliban. Edited by Alex Strick van Linschoten and Felix Kuehn. Hurst/Columbia University Press.

\section{$\underline{\text { Non-Academic Press Books }}$}

Adamec, Ludwig W. 2006. Historical Dictionary of Afghan Wars, Revolutions and Insurgencies. New Delhi: Manas Publications.

Amin, Agha H., et al. 2010. The Development of Taliban Factions in Afghanistan and Pakistan: A Geographical Account. Mellen Press.

Chayes, Sarah. 2006. The Punishment of Virtue: Inside Afghanistan After the Taliban. New York: The Penguin Press.

Coll, Steve. 2004. Ghost Wars: The Secret History of the CIA, Afghanistan, and Bin Laden, from the Soviet Invasion to September 10, 2001. Penguin. 
Ewans, Martin. 2002. Afghanistan: A Short History of its People and Politics. New York: Harper Collins.

Feifer, Gregory. 2008. The Great Gamble: The Soviet War in Afghanistan. New York: Harper Collins.

Fergusson, James. 2010. Taliban. Bantam Press.

Fergusson, James. 2011. Taliban: The Unknown Enemy. Da Capo Press.

Fitzgerald, Paul and Elizabeth Gould. 2009. Invisible History: Afghanistan's Untold Story. City Lights Publishers.

Foust, Joshua. 2010. Afghanistan Journal: Selections from Registan.net. Just World.

Ghaus, Abdul Samad. 1988. The Fall of Afghanistan: An Insider's Account. Brassey's (UK) Ltd; 1 edition.

Girardet, Edward. 2011. Killing the Cranes: A Reporter's Journey Through Three Decades of War in Afghanistan. Chelsea Green Publishing.

Gould, Elizabeth and Paul Fitzgerald. 2011. Crossing Zero: The AfPak War at the Turning Point of American Empire. City Lights.

Griffiths, John C. 2009. Afghanistan: Land of Conflict and Beauty. Andre Deutsch.

Griffin, Michael. 2001. Reaping the Whirlwind: The Taliban Movement in Afghanistan. Sterling, VA: Pluto Press.

Gutman, Roy. 2008. How We Missed the Story: Osama Bin Laden, the Taliban and the Hijacking of Afghanistan. United States Institute of Peace Press.

Hastings, Michael. 2011. The Operators: The Wild and Terrifying Inside Story of America's War in Afghanistan. Little, Brown \& Co.

Isby, David. 2010. Afghanistan: Graveyard of Empires: A New History of the Borderland. Pegasus.

Jawad, Nassim. 1992. Afghanistan: A Nation of Minorities. London.

Johnson, Chris, and Jolyon Leslie. 2005. Afghanistan: The Mirage of Peace. Zed Books.

Lamb, Christina. 2008. Not a Shot Fired: The War on terror in Afghanistan. Harper.

Loyn, David. 2008. Butcher and Bolt: Two Hundred Years of Foreign Failure in Afghanistan. UK: Hutchinson. 
Magnus, Ralph H. and Eden Naby. 1998. Afghanistan: Mullah, Marx, and Mujahid. Boulder, CO: Westview Press.

Maloney, Sean. 2005. Enduring the Freedom: A Rogue Historian in Afghanistan. Washington DC: Potomac Books.

Marsden, Peter. 2002. The Taliban: War and Religion in Afghanistan. Zed Books.

Marsden, Peter. 2001. Afghanistan: Minorities, Conflict and the Search for Peace. London: Minority Rights Group International.

McCauley, Martin. 2002. Afghanistan and Central Asia: A Modern History. New York: Longman Publications.

Neumann, Ronald E. 2009. The Other War: Winning and Losing in Afghanistan. Potomac Books.

Nojumi, Neamatollah 2002. The Rise of the Taliban in Afghanistan. New York: Palgrave.

Shanty, Frank C. 2011. The Nexus: International Terrorism and Drug Trafficking from Afghanistan. Praeger.

Sreedhar, Mahendra and Ved. 1998. Afghan Turmoil: Changing Equations. New Delhi: Himalayan Books.

Tanner, Stephen. 2002. Afghanistan: A Military History from Alexander the Great to the Fall of the Taliban. Cambridge, MA: Da Capo Press.

Tomsen, Peter. 2001. The Wars of Afghanistan: Messianic Terrorism, Tribal Conflicts, and the Failures of Great Powers. PublicAffairs.

Torwayana, Najib Ullah. 2002. A Short History of Afghanistan. Authorhouse.

Tripathi, Deepak. 2011. Breeding Ground: Afghanistan and the Origins of Islamist Terrorism. Potomac Books.

Vogelsang, Willem. 2001. The Afghans. Boston: Blackwell Publications.

Yunas, S. Fida. 1997. Afghanistan: Jirghas and Loya Jirghas; The Afghan Tradition (977A.D. to 1992 A.D.). Published in Peshawar. 


\section{$\underline{\text { Articles, reports, and chapters in books }}$}

Afsar, Shahid A. and Cristopher A Samples. 2008. The evolution of the Taliban. Naval Postgraduate School Master's thesis. Download PDF.

Ahady, Anwar-ul-Haq. 1991. 'Conflict in post-soviet-occupation Afghanistan', Journal of Contemporary Asia, Vol. 21, Issue 4, pp. 513 - 528.

Akbar, Mansoor. 1988. 'Revolution and counterrevolution in Afghanistan', Journal of Contemporary Asia, Vol. 18, No. 4

Amin, A. Rasul. 1984. 'A general reflection on the stealthy Sovietisation of Afghanistan', Central Asian Survey, 3(1), pp. 47-61.

Amin, Tahir. 1984. 'Afghan Resistance: Past, Present, and Future’, Asian Survey, 24(4).

Atran, Scott. 2010. 'A Question of Honour: Why the Taliban Fight and What to Do About It', Asian Journal of Social Science, Vol. 38.

Azerbaijani Moghaddam, Sippi. 2009. 'Northern Exposure for the Taliban', in Antonio Giustozzi (ed.) Decoding the New Taliban: Insights from the Afghan Field.

Hurst/Columbia University Press.

Azoy, Whitney. 2003 'Masood’s Parade: Iconography, Revitalization and Ethnicity in Afghanistan’, Expedition, Vol. 45, No. 1.

Baev, Pavel K. 2008. 'Sad Wisdom of Hindsight: Soviet Intervention in Afghanistan (1979-1989)', in Cheryl Benard et al, eds, Afghanistan: State and Society, Great Power Politics and the Way Ahead. Santa Monica, CA: RAND Corp.

Barakat, Sultan and S. Zyck. 2010. 'Afghanistan's insurgency and the viability of a political solution', Studies in Conflict and Terrorism, Vol. 33, No. 3.

Barfield, Thomas. 2007. 'The Durand Line: History, Consequences and Future', Report of a Conference Organized in July 2007 by the American Institute of Afghanistan Studies and the Hollings Center in Istanbul, Turkey. Download PDF.

Barfield, Thomas. 2005. 'Afghanistan is Not the Balkans: Ethnicity and its Political Consequences from a Central Asian Perspective’, Central Eurasian Studies Review, Volume 4, Number 1, Winter 2005. Download PDF.

Barfield, Thomas. 2004. 'Problems in Establishing Legitimacy in Afghanistan', Iranian Studies, Vol. 37, No. 2.

Barfield, Thomas. 1996. ‘The Afghan Morass’, Current History, 95(597). 
Barfield, Thomas. 1984. 'Structural Weaknesses in Provincial Administration', in Revolutions and Rebellions in Afghanistan: Anthropological Perspectives. M. Nazif Shahrani and Robert L Canfield (Eds.) Institute of International Studies, UC Berkeley.

Barfield, Thomas, Neamat Nojumi and J. Alexander Their. 2006 'The Clash of Two Goods: State and non-State Dispute Resolution in Afghanistan', USIP. Download PDF.

Bergh, Gina et al. 2009. 'Conflict analysis: Jaghori and Malistan districts, Ghazni province’, CPAU. Download PDF.

Berman, Eli, et al. 2011. 'Do Working Men Rebel? Insurgency and Unemployment in Afghanistan, Iraq and the Philippines', Journal of Conflict Resolution (March 2011).

Bhattacharjee, Hrishiraj. 2011. 'All (not) quiet on the western front', CAPS. PDF.

Bhattacharya, Sauri P. 1984. 'Soviet Nationality Policy in Afghanistan', Asian Affairs, Vol. 15, No. 2.

van Bijlert, Martine. 2010. 'Militancy and Conflict in Zabul and Uruzgan', New America Foundation. Download PDF.

van Bijlert, Martine. 2009. 'Unruly Commanders and Violent Power Struggles: Taliban Networks in Uruzgan', in Antonio Giustozzi (ed.) Decoding the New Taliban: Insights from the Afghan Field. Hurst/Columbia University Press.

Bijleveld, Sophia Milosevic. 2008. 'Afghanistan: Re-imagining the Nation through the Museum - The Jihad Museum in Herat', Studies in Ethnicity and Nationalism, 6(2).

Binnie, Jeremy and Joanna Wright. 2009. 'The Evolving Role of Uzbek-led Fighters in Afghanistan and Pakistan’, CTC Sentinel, Vol. 2, No. 8. Download PDF.

Brahimi, Alia. 2010. ‘The Taliban’s Evolving Ideology’, LSE. Download PDF.

Bruscino, Thomas A. Jr. 2006. 'Out of Bounds: Transnational Sanctuary in Irregular Warfare’, Global War on Terrorism Occasional Paper 17. Download PDF.

Canfield, Robert L. 2010. 'Efficacy and Hierarchy: Practices in Afghanistan as an Example', in Ethnicity, Authority, and Power in Central Asia: New Games Great and Small. Edited by Robert L. Canfield and Gabriele Rasuly-Paleczek. Routledge.

Canfield, Robert L. 2008. 'Fraternity, Power, and Time in Central Asia', in Robert D Crews and Amin Tarzi (editors). The Taliban and the Crisis of Afghanistan. Cambridge, MA: Harvard University Press.

Canfield, Robert L. 1992. 'Restructuring in Greater Central Asia: Changing Political Configurations’, Asian Survey, Vol. 32, No. 10: pp. 875-887. 
Canfield, Robert L. 1989. 'Afghanistan: the trajectory of internal alignments', The Middle East Journal, 43(4), pages 635-648.

Canfield, Robert L. 1988. ‘Afghanistan’s social identities crisis’, in Jean-Pierre Digard (editor), Le Fait Ethnique en Iran et en Afghanistan. Paris.

Canfield, Robert L. 1986. 'Ethnic, Regional, and Sectarian Alignments in Afghanistan' in The State, Religion, and Ethnic Politics: Afghanistan, Iran, and Pakistan. Ali Banuazizi and Myron Weiner (Eds.) Syracuse: Syracuse University Press.

Centlivres, Pierre and Micheline Centlivres-Demont. 2000. 'State, National Awareness and Levels of Identity in Afghanistan from Monarchy to Islamic State', in Central Asian Survey, Vol.19, No. 3/4, pp. 419-428.

Coghlan, Tom. 2009. 'The Taliban in Helmand: An Oral History', in Antonio Giustozzi (ed.) Decoding the New Taliban: Insights from the Afghan Field. Hurst/Columbia.

Cordesman, Anthony H. 2008. 'US Casualties: The Trends in Iraq and Afghanistan', CSIS report. Download PDF.

Cordesman, Anthony H. 2008. 'Losing The Afghan-Pakistan War? The Rising Threat', CSIS. Download PDF.

Cordesman, Anthony H. 2008. ‘Analyzing the Afghan-Pakistan War’, CSIS. PDF.

Cordesman, Anthony H. 2007. 'The Struggle for Pashtunistan: The Afghan-Pakistan War', CSIS. Download PDF.

Crews, Robert D. 2008. 'Moderate Taliban?', in Robert D Crews and Amin Tarzi (editors). The Taliban and the Crisis of Afghanistan. Cambridge, MA: Harvard University Press.

Cynkin, Thomas M. 1982. 'Aftermath of the Saur Coup: Insurgency and Counterinsurgency in Afghanistan’, Fletcher Forum, Vol. 6, No. 2.

Dalili, Raz Mohammad. 2004. 'Ethnicity and Peace-Building and Reconstruction in Afghanistan’, JCAS Symposium Series, 21.

Davis, Anthony. 1998. 'How the Taliban became a Military Force', in William Maley (editor) Fundamentalism Reborn? Afghanistan and the Taliban. New York: New York University Press.

Dearing, Matt. 2010. 'Like Red Tulips at Springtime: Understanding the Absence of Female Martyrs in Afghanistan', Studies in Conflict \& Terrorism, Vol. 33, No. 12. 
Dearing, Matthew. 2008. 'Examining the Suicide Terror Movement in Afghanistan', The Culture and Conflict Review, Summer 2008. Download PDF.

Dennys, Christian and I. Zaman. 2009. 'Trends in local Afghan conflicts’, CPAU. PDF.

Devlin, Lawrence et al. 2009. 'Conflict analysis: Kunduz city, Kunduz province’, CPAU. Download PDF.

Dietl, Gulshan. 2004. 'War, peace and the warlords: the case of Ismail Khan of Herat in Afghanistan', Alternatives: Turkish Journal of International Relations, Vol. 3, No. 2\&3 (Summer and Fall 2004), pages 41-66. Download PDF.

Dobson, Rhea E. 2008. 'Chaos Theory and the Effort in Afghanistan', U.S. Army War College Strategy Research Project. Download PDF.

Dorronsoro, Gilles. 2007. 'Kabul at War (1992-1996): State, Ethnicity and Social Classes’, South Asia Multidisciplinary Academic Journal, 14. Download PDF.

Dorronsoro, Gilles. 2006. “Le mouvement des Taleban en Afghanistan’, Cemoti, No. 19. Read online.

Dorronsoro, Gilles. 2004. 'Les Talebans entre direction charismatique, réseaux cléricaux et solidarités communautaires’, in Cemoti, No. 27. Read online.

Dorronsoro, Gilles. 2003. 'Afghanistan: chronique d’un échec annoncé’, Critique internationale, No. 21. Download PDF.

Dorronsoro, Gilles. 2003. 'Afghanistan: the Delusions of Victory', IPG 2/2003. PDF.

Dorronsoro, Gilles. 2001. 'Après les Taleban: fragmentation politique, hiérarchie communautaire et classes sociales en Afghanistan’, Cultures \& Conflits, 44 . Online.

Dorronsoro, Gilles. 1996. 'Désordre et légitimité du politique en Afghanistan', Cultures \& Conflits, 24-25. Read online.

Dorronsoro, Gilles and Chantal Lobato. 1989. 'The Militia in Afghanistan', Central Asian Survey, Volume 8, Issue 4, pages 95-108.

Dressler, Jeffrey. 2011. 'Counterinsurgency in Helmand', Institute for the Study of War. Download PDF.

Dressler, Jeffrey A. 2010. 'The Haqqani Network: From Pakistan to Afghanistan’. ISW Afghanistan Report No. 6. Download PDF.

Drumbl, Mark A. 2002. ‘The Taliban’s ‘other’ crimes’, Third World Quarterly, 23. 
Dunbar, Charles. 1987. 'Afghanistan in 1986: The Balance Endures’, Asian Survey, 27(2).

Dupree, Louis. 1984. 'Tribal warfare in Afghanistan and Pakistan: a reflection of the segmentary lineage system', in A.S. Ahmed and David Hart (editors), Islam in Tribal Societies. London: Routledge and Kegan Paul.

Dupree, Louis. 1984. 'The Marxist Regimes and the Soviet Presence in Afghanistan', in Revolutions \& Rebellions in Afghanistan: Anthropological Perspectives. M. N. Shahrani and R. L. Canfield, eds. Berkeley: Institute of International Studies.

Edwards, David B. 1994. 'Afghanistan, ethnography and the new world order', Cultural Anthropology, Vol. 9, no. 3, pp. 345-360.

Edwards, David B. 1986. 'Charismatic leadership and political process in Afghanistan', Central Asian Survey, 5(3-4).

Elias, Mohammad Osman Tariq. 2009. 'The Resurgence of the Taliban in Kabul: Logar and Wardak', in Antonio Giustozzi (ed.) Decoding the New Taliban: Insights from the Afghan Field. Hurst/Columbia University Press.

Emadi, Hafizullah. 2001. 'Radical political movements in Afghanistan and their politics of peoples' empowerment and liberation', Central Asian Survey, 20(4), pp. 427 - 450.

Esser, Daniel. 2004. 'The City as Arena, Hub and Prey: Patterns of Violence in Kabul and Karachi', Environment \& Urbanization, Vol. 16, No. 2.

Forsberg, Carl. 2010. 'Politics and Power in Kandahar', Institute for the Study of War. Download PDF.

Forsberg, Carl. 2009. ‘The Taliban’s Campaign for Kandahar’, Afghanistan Report \#3. Institute for the Study of War. Download PDF.

FRIDE. 2008. 'Afghanistan, the limits of counter-insurgency', FRIDE. Download PDF.

Geller, Armando and Shah Jamal Alam. 2010. 'A Socio-Political and -Cultural Model of the War in Afghanistan', International Studies Review, Vol. 12, No. 1.

Geller, Armando and Scott Moss. 2008. 'Growing Qawm: An Evidence Driven Declarative Model of Afghan Power Structures’, Advances in Complex Systems, 11(2).

Ghani, Ashraf. 1987. 'The Afghan State and its Adaptation to the Environment of Central and Southwest Asia', in Hafeez Malik, (ed.) Soviet-American Relations with Pakistan, Iran and Afghanistan. New York: St. Martin’s Press.

Gibbs, David. 2006. 'Reassessing Soviet Motives for Invading Afghanistan: A Declassified History', Critical Asian Studies 38, no. 2. Download PDF. 
Gibbs, David. 2000. 'Afghanistan: The Soviet Invasion in Retrospect', International Politics 37, no. 2. Download PDF.

Gibbs, David. 1986. 'The Peasant as Counterrevolutionary: The Rural Origins of the Afghan Insurgency', Studies in Comparative International Development, Vol. 21(1).

Giustozzi, Antonio and Christoph Reuter. 2011. 'The Insurgents of the Afghan North', Afghanistan Analysts Network. Download PDF.

Giustozzi, Antonio. 2011. 'Double-edged swords: armies, elite bargaining and statebuilding’, Crisis States Research Centre, Working Paper no. 86. Download PDF.

Giustozzi, Antonio. 2010. 'The Taliban Beyond the Pashtuns’, CIGI, The Afghanistan Papers No. 5. Download PDF.

Giustozzi, Antonio. 2010. 'The 'Great Fears' of Afghanistan: How wild rumours shape politics’, IDEAS Today, Issue 4. Download PDF.

Giustozzi, Antonio. 2010. 'Negotiating with the Taliban: Issues and Prospects', The Century Foundation. Download PDF.

Giustozzi, Antonio and Christoph Reuter. 2010. 'The Northern Front: The Afghan insurgency spreading beyond the Pashtuns', Afghanistan Analysts Network. Download PDF.

Giustozzi, Antonio. 2010. 'Between Patronage and Rebellion: Student Politics in Afghanistan’, AREU. Download PDF.

Giustozzi, Antonio, and Christoph Reuter. 2010. 'The Northern Front: The Afghan Insurgency Spreading beyond the Pashtuns’, Afghanistan Analysts Network. PDF.

Giustozzi, Antonio. 2009. 'The Taliban’s Marches: Heart, Farah, Baghis and Ghor', in Antonio Giustozzi (ed.) Decoding the New Taliban: Insights from the Afghan Field. Hurst/Columbia University Press.

Giustozzi, Antonio. 2009. 'Afghanistan: ‘friction’ between civilizations', in Stig Hansen et al (eds.), The borders of Islam: exploring Huntington's faultines, from Al-Andalus to the virtual Ummah. Hurst, London, UK.

Giustozzi, Antonio. 2009. 'One or many? The Issue of the Taliban’s Unity and Disunity', Pakistan Security Research Unit. Download PDF.

Giustozzi, Antonio. 2009. 'The eye of the Storm: Cities in the Vortex of Afghanistan's Civil Wars', Crisis States Research Centre, Working Paper No. 62. Download PDF. 
Giustozzi, Antonio. 2009. 'The Pygmy who turned into a Giant: The Afghan Taliban in 2009', in Afghanistan: Now You See Me? IDEAS Strategic Update 001. Download PDF.

Giustozzi, Antonio. 2008. 'Armed politics and political competition in Afghanistan', CMI Research Paper. Download PDF.

Giustozzi, Antonio. 2008. 'Afghanistan: political parties or militia fronts?', in de Zeeuw, J, (ed.) From soldiers to politicians: transforming rebel movements after civil war. Lynne Rienner Publishers, Boulder, CO.

Giustozzi, Antonio. 2007. 'War and Peace Economies of Afghanistan’s Strongmen', International Peacekeeping, Vol. 14, No. 1.

Giustozzi, Antonio. 2007. 'The Missing Ingredient: Non-Ideological Insurgency and State Collapse in Western Afghanistan, 1979-1992', Crisis States Programme Working Paper, No. 11. Download PDF.

Giustozzi, Antonio. 2006. 'Genesis of a Prince: The Rise of Ismail Khan in Western Afghanistan, 1979-1992', Crisis States Programme Working Paper Series \#2, No. 4. Crisis States Research Center (September 2006). Download PDF.

Giustozzi, Antonio and Noor Ullah. 2006. “Tribes” and Warlords in Southern Afghanistan, 1980-2005’, Crisis States Programme Working Paper, No. 7. PDF.

Giustozzi, Antonio. 2005. 'The Ethnicisation of an Afghan Faction: Junbesh-I-Milli from its Origins to the Presidential Elections', Crisis States Programme Working Paper, No. 67. Crisis States Research Center (September 2005). Download PDF.

Giustozzi, Antonio. 2005. 'Warlords into Businessmen: the Afghan Transition, 20022005', Paper presented at the “Transforming War Economies” Seminar. Download PDF.

Giustozzi, Antonio. 2005 'The Debate on Warlordism: The Importance of Military Legitimacy’, Crisis States Programme Discussion Paper, No. 13. Download PDF.

Giustozzi, Antonio. 2003. 'Respectable Warlords? The Politics of State-Building in PostTaleban Afghanistan’, Crisis States Programme Working Paper, No. 33. Download PDF.

Glatzer, Bernt. 2002. 'Centre and Periphery in Afghanistan: New Identities in a Broken State’, Sociologus, winter.

Glatzer, Bernt. 2001. 'War and Boundaries in Afghanistan: Significance and Relativity of Local and Social Boundaries', Weld des Islams, Vol. 41, No. 3. Download PDF.

Glatzer, Bernt. 1998. 'Is Afghanistan on the Brink of Ethnic and Tribal Disintegration?', in William Maley (editor) Fundamentalism Reborn? Afghanistan and the Taliban. New York: New York University Press. 
Goodson, Larry. 1998. 'The Fragmentation of Culture in Afghanistan', Alif: Journal of Comparative Poetics, No. 18, Post-Colonial Discourse in South Asia, pp. 269-289.

Goodson, Larry P. 1998 'Periodicity and intensity in the Afghan War', Central Asian Survey, $17: 3$, pp. $471-488$.

Gopal, Anand. 2010. 'The Battle for Afghanistan: Militancy and Conflict in Kandahar', New America Foundation. Download PDF.

Gopal, Anand and Matthew DuPee. 2010. 'Tensions Rise Between Hizb-i-Islami and the Taliban in Afghanistan’, CTC Sentinel, Vol. 3, No. 8. Download PDF.

Grare, Frédéric. 2006. 'Pakistan-Afghanistan Relations in the Post-9/11 Era', Carnegie Papers South Asia Project, No. 72 (October 2006). Download PDF.

Grau, Lester W. 2007. 'Breaking Contact Without Leaving Chaos: The Soviet Withdrawal from Afghanistan', The Journal of Slavic Military Studies, Vol. 20, No. 2.

Green, Dan. 2009. 'The Taliban’s political program’, Armed Forces Journal, November. Read online.

Grevemeyer, Jan-Heeren. 1988. 'Ethnicity and national liberation: the Afghan Hazara between resistance and civil war', in Jean-Pierre Digard (editor), Le Fait Ethnique en Iran et en Afghanistan. Paris.

Grevemeyer, Jan-Heeren. 1985. 'Religion, ethnizitat und Nationalismus im afghanische Widerstand', Leviathan, 13 (1), pages 115-128.

Hansen, Cole et al. 2009. 'Conflict analysis: Baharak district, Badakhshan province', Cooperation for Peace and Unity, February 2009. Download PDF.

Harpviken, Kristian Berg. 2010. 'Understanding Warlordism: Three Biographies from Afghanistan’s Southeastern Areas’, International Peace Research Institute. PDF.

Harpviken, Kristian Berg. 2006. 'The Transnationalization of the Taliban', Paper presented at the workshop on Transnationalism and Civil War. Download PDF.

Harpviken, Kristian Berg. 1997. 'Transcending nationalism: the emergence of non-state military formations in Afghanistan', Journal of Peace Research, 34(3), pages 271-287.

Hatch-Dupree, Nancy. 'Cultural Heritage and national Identity in Afghanistan', in Third world quarterly, 23: 977-989 (October 2002).

Human Terrain System. 2010. ‘Kandahar Province Survey Report.’ Download PDF. 
Hyman, Anthony. 2002. 'Nationalism in Afghanistan', International Journal of Middle East Studies, Vol. 34, pp. 299-315.

Ibrahimi, Niamatullah. 2009. 'Divide and rule: State penetration in Hazarajat from monarchy to the Taliban', Working Paper No: 42 (series 2). Download PDF.

Ibrahimi, Niamatullah. 2009. 'At the sources of Factionalism and Civil War in Hazarajat', Working Paper No : 41 (series 2). Download PDF.

ICG. 2008. 'Taliban Propaganda: Winning the war of Words?’, Asia Report Nº158.

ICoS. 2008. 'Struggle for Kabul: the Taliban Advance', International Council on Security and Development.' Download PDF.

Jackson, Paul. 2003. 'Warlords as alternative Forms of Governance', Small Wars \& Insurgencies, Vol. 14, No. 2.

Jalali, Ali. A. 2001. 'Afghanistan: anatomy of an ongoing conflict', Parameters, Spring.

Janata, Alfred. 1990. 'Afghanistan: the ethnic dimension', in E. W. Anderson and N. Hatch Dupree (eds), The Cultural Basis of Afghan Nationalism. Oxford University Press.

Johnson, Thomas H. and Ahmad Waheed. 2011. 'Analyzing Taliban taranas (chants): an effective Afghan propaganda artifact’, Small Wars \& Insurgencies, Vol. 22, No.1.

Johnson, Thomas H. and M. Chris Mason. 2008. 'No Sign until the Burst of Fire: Understanding the Pakistan-Afghanistan Frontier', International Security, Vol. 32, No. 4.

Johnson, Thomas H. 2007. 'On the Edge of the Big Muddy: The Taliban Resurgence in Afghanistan’, China and Eurasia Forum Quarterly, Vol. 5, no. 2. Download PDF.

Johnson, Thomas H. and M. Chris Mason. 2007. 'Understanding the Taliban and Insurgency in Afghanistan’, Orbis, Vol. 51, No. 1.

Johnson, Thomas H. 2004. 'Ismail Khan, Herat and Iranian Influence', Strategic Insights, Vol. 3, No. 7

Jones, Seth G. 2008. 'The Rise of Afghanistan's Insurgency: State Failure and Jihad', International Security, Vol. 32, No. 4, pp. 7-40.

Judah, Tim. 2002. ‘The Taliban Papers’, Survival, Vol. 44, No. 1, pp. 69-80.

Kagan, Frederick W., Kimberly Kagan and Danielle Pletka. 2008. 'Iranian Influence in the Levant, Iraq, and Afghanistan', American Enterprise Institute. Download PDF. 
Kalinovsky, Artemy. 'Soviet Decision-making during the War in Afghanistan, from Intervention to Withdrawal', Journal of Cold War Studies (Forthcoming).

Kalinovsky, Artemy. 2008. 'Old politics, new diplomacy: the Geneva accords and the Soviet withdrawal from Afghanistan’, Cold War History, Vol. 8, No. 3.

Keller, Arthur. 2008. 'Propaganda and Peace Deals: The Taliban's Information War in Pakistan’, CTC Sentinel, Vol 1, Issue 8. Download PDF.

Kemp, Robert. 2008. 'Religious Extremism and Militancy in the Pashtun Areas of Afghanistan and Pakistan’, BC Journal, Special Volume / Fall 2008. Read online.

Khalilzad, Zalmay. 1996. 'Afghanistan in 1995: Civil War and a Mini-Great Game’, Asian Survey, Vol. 36, No. 2, pp. 190-195

Khan, Ijaz. 1998. ‘Afghanistan: A geopolitical study’, Central Asian Survey, 17(3).

Kjærnet, Heidi and Stina Torjesen. 2008. 'Afghanistan and regional instability: A risk assessment’, NUPI Report, Norwegian Institute of International Affairs. Download PDF.

Koehler, Jan and Christoph Zuercher. 2007. 'State-Building, Conflict and Narcotics: The View from Below’, International Peacekeeping, Vol. 14, No. 1.

Komano, Kinichi. 2005. 'The Role of Elections in the Peace-Building and Reconstruction of Afghanistan', Asia Pacific Review, Volume 12, Number 1, (May 2005): pages 1-16.

Kongsgård, Håvard Wahl. 2011. 'The Genetics of Conflict: Low Level Interaction between Conflict Events.' Link to PDF.

Lafraie, Najibullah. 2008. 'Resurgence of the Taliban insurgency in Afghanistan: How and why?', International Politics, Vol. 46, 1. Download PDF.

Lieven, Anatol. 2009. 'The war in Afghanistan: its background and future prospects', Conflict, Security \& Development, Vol. 9, Issue 3.

Logashova, B. -R, 1991. 'Etnokultunaia sitsuatsiia v Afganistane', Rosy i narody, No. 16.

Maass, Citha D. 1999. 'The Afghanistan conflict: external involvement', Central Asian Survey, 18(1), pp. 65-78.

MacEachin, Doug and Janne E. Nolan (chairs). 2005. 'The US and Soviet Proxy War in Afghanistan, 1989-1992: Prisoners of Our Preconceptions?', Institute for the Study of Diplomacy Working Group Report, No. IV. Download PDF.

MacKenzie, Jean. 2010. 'Militancy and Conflict in Helmand', New America Foundation. Download PDF. 
Maley, William. 2006. 'A “War against Terrorism”? Afghanistan, Iraq and Palestine’, JCAS Symposium Series, 24.

Magnus, Ralph H. and Eden Naby 1995. 'Afghanistan and Central Asia: Mirrors and Models’, Asian Survey, Vol. 35, No. 7 (July 1995), pp. 605-620.

Maley, William. 1998. 'Interpreting the Taliban', in William Maley (editor)

Fundamentalism Reborn? Afghanistan and the Taliban. New York University Press.

Maley, William. 1997. 'The Dynamics of Regime Transition in Afghanistan', Central Asian Survey, Vol. 16, No. 2.

Malkasian, Carter and Jerry Meyerle. 2009. 'How is Afghanistan Different from Al Anbar?', CNA Report. February 2009. Download PDF.

Marten, Kimberly. 2007. 'Warlordism in Comparative Perspective', International Security, Vol. 31, No. 3.

Merkova, Sonya et al. 2009. 'Conflict analysis: Chak and Sayedabad districts, Wardak province’, Cooperation for Peace and Unity report, April 2009. Download PDF.

Mielke, Katja und Conrad Schetter. 2009. 'Wiederholt sich Geschichte? Die legitimatorischen Deutungsmuster der Interventionen in Afghanistan 1979 und 2001', Peripherie, Nr. 116, 29. Download PDF.

Millen, Raymond A. 2005. 'Afghanistan: Reconstituting a Collapsed State’, Strategic Studies Institute Monograph. Download PDF.

Mili, Hayder and Jacob Townsend. 2009. 'Tribal Dynamics of the Afghanistan and Pakistan Insurgencies’, CTC Sentinel, Vol. 2, No. 8. Download PDF.

Mishali-Ram, Meirav. 2008. 'Afghanistan: A Legacy of Violence? Internal and External Factors of the Enduring Violent Conflict', Comparative Studies of South Asia, Africa and the Middle East, Vol. 28, No. 3. Download PDF.

Mitrokhin, Vasily. 2009. 'The KGB in Afghanistan', Cold War International History Project Working Paper \#40. Download PDF.

Mohan, Raj P. 2005. 'Genocide as a possible response to westernization: government treatment of minorities in Afghanistan and Iran', in G. C. Kinloch and R. P. Mohan (eds), Genocide: Approaches, Case Studies, and Responses. New York: Algora Publishing.

Mousavi, Sayed Askar. 2006. 'Transnational Afghani Audiences after September 11', Journal of Ethnic and Migration Studies, 32(6). August 2006. Pages 1041-1061. 
Naby, Eden. 1988. 'Ethnic Factors in Afghanistan's Future', in Bo Huldt and Erland Jansson (editors). The Tragedy of Afghanistan: The Social, Cultural, and Political Impact of the Soviet Invasion. London: Croom Helm Limited.

Naby, Eden. 1980. 'The Ethnic Factor in Soviet-Afghan Relations', Asian Survey, 20(3).

Nathan, Joanna. 2009. 'Reading the Taliban', in Antonio Giustozzi (ed.) Decoding the New Taliban: Insights from the Afghan Field. Hurst/Columbia University Press.

Nathan, Joanna. 2009. 'A Review of Reconciliation Efforts in Afghanistan', CTC Sentinel, Vol. 2, No. 8. Download PDF.

Newell, Richard S. 1989. 'Post-Soviet Afghanistan: the position of minorities', Asian Survey, 29(11), pages 1090-1108.

Niamatullah, Ibrahimi. 2006. 'The Failure of a Clerical Proto-State: Hazarajat, 19791984', Crisis States Working Paper, No. 6. Download PDF.

Nichols, Robert. 2005. Afghan Historiography: Classical Study, Conventional Narrative, National Polemic', History Compass, 3 (2005) AS 141, 1-16.

Nojumi, Neamatollah. 2008. 'The Rise and Fall of the Taliban', in Robert D Crews and Amin Tarzi (editors). The Taliban and the Crisis of Afghanistan. Cambridge, MA: Harvard University Press.

Norell, Magnus. 2007. 'The Taliban and the Muttahida Majlis-e-Amal (MMA)', China and Eurasia Forum Quarterly, Volume 5, No. 3 (2007) p. 61-82. Download PDF.

Oehme III, Chester G. 2008. 'Terrorists, Insurgents, and Criminals - Growing Nexus?', Studies in Conflict \& Terrorism, Vol. 31, No. 1, pp. 80-93.

Oleinik, Anton. 2008. 'Lessons of Russian in Afghanistan', Society, Vol. 45, No. 3.

Ollapally, Deepa, et al. 2003. 'Unfinished Business in Afghanistan: Warlordism, Reconstruction, and Ethnic Harmony’, USIP, Special Report 105. Download PDF.

Parvanta, Angela. 2002. 'Afghanistan - Land of the Afghans? On the Genesis of a Problematic State Denomination', in C. Noelle-Karimi et al (editors) Afghanistan - A Country without a State? Frankfurt am Main, Germany: IKO.

Peake, Gordon et al. 2004. 'From warlords to peace lords: local leadership capacity in peace process’, INCORE Report. Download PDF.

Pennes, Sébastien. 2008. 'L'Insurrection talibane: guerre économique ou idéologique?', Politique étrangère, 73 (2008):2, pp. 345-358. 
Peters, Gretchen. 2010. 'Crime and Insurgency in the Tribal Areas of Afghanistan and Pakistan’, Combating Terrorism Center. Download PDF.

Phillips, Andrew. 2009. 'The Anbar Awakening: Can It Be Exported to Afghanistan?’, Security Challenges, Vol. 5, No. 3. Download PDF.

Pohly, Michael. 2002. 'Perceptions of State and Organisation of the Northern Alliance', in Christine Noelle-Karimi, Conrad Schetter and Reinhard Schlagintweit (editors) Afghanistan - A Country Without a State? Frankfurt am Main, Germany: IKO.

Pstrusinska, Jadwiga. 1990. 'On the Sociolinguistic Epilogue of the War in Afghanistan', in Contacts Between Cultures: Eastern Asia: Literature and Humanities, Vol. 3. Edited by Bernard Hung-Kay Luk. Lewiston/Queenston/Lampeter: The Edwin Mellen Press.

Radnitz, Scott. 2004. 'Working with the Warlords: Designing an Ethnofederal System for Afghanistan', Regional and Federal Studies, Vol. 14, No. 4, Winter 2004, pp. 513-537.

Rahimi, Roohullah. 2008. 'Afghanistan: Exploring the Dynamics of Sociopolitical Strife and the Persistence of the Insurgency’, Pearson Peacekeeping Centre. Download PDF.

Rais, Rasul Bakhsh. 2000. ‘Afghanistan: A Forgotten Cold War Tragedy’, Ethnic Studies Report, Vol. XVIII, No. 2.

Rais, Rasul Bakhsh. 1999. 'Conflict in Afghanistan: Ethnicity, Religion and Neighbours', Ethnic Studies Report, Vol. 17, No. 1 (January 1999), pp. 1-12.

Rashid, Ahmed. 2006. 'Afghanistan: Progress since the Taliban', Asian Affairs, 37(1).

Rasuly-Paleczek, Gabriele. 2001. 'The Struggle for the Afghan State: Centralization, Nationalism and their Discontents', in Willem Van Schendel and Erik J. Zurcher (editors) Identity Politics in Central Asia and the Muslim World: Nationalism, Ethnicity and Labour in the Twentieth Century. London: I.B. Tauris Publishers.

Reuter, Christoph and Borhan Younus. 2009. 'The return of the Taliban in Andar District: Ghazni', in Antonio Giustozzi (ed.) Decoding the New Taliban: Insights from the Afghan Field. Hurst/Columbia University Press.

Reuveny, Rafael and Aseem Prakash. 1999. 'The Afghanistan war and the breakdown of the Soviet Union', Review of International Studies, Vol. 25, pp. 693-708.

Rieck, Andreas. 1997. ‘Afghanistan’s Taliban: An Islamic Revolution of the Pashtuns’ in Orient, Vol. 38, No. 1.

Roy, Olivier. 2002. 'Afghanistan: Internal Politics and Socio-Economic Dynamics and Groupings', WRITENET Paper, No. 14. Download PDF. 
Roy, Olivier. 1994. 'The new political elite of Afghanistan', in The politics of social transformation in Afghanistan, Iran and Pakistan. Ed. by Myron Weiner and Ali Banuazizi. Syracuse: Syracuse University Press.

Roy, Olivier. 1993. 'La guerre d'Afghanistan: de la guerre idéologique à la guerre ethnique', L'homme et la société, No. 107/108, pp. 87-92.

Roy, Olivier. 1992. 'Ethnic identity and political expression in northern Afghanistan', in J. Gross (ed.), Muslims in Central Asia: Expressions of Identity and Change. Durham.

Roy, Olivier. 1992. 'Political elites in Afghanistan: rentier state building, rentier state wrecking’, International Journal of Middle East Studies, 24.

Roy, Olivier. 1989. 'Afghanistan, back to tribalism or on to Lebanon', Third World Quarterly, Vol. 11, no 1.

Roy, Olivier. 1989. 'Afghanistan: war as a factor of entry into politics', Central Asian Survey, Volume 8, Issue 4, pp. 43-62.

Roy, Olivier. 1988. 'Ethnies et appartenances politiques en Afghanistan', in Le fait ethnique en Iran et en Afghanistan. dir. Jean-Pierre Digard. - Paris : Ed. du CNRS.

Rubin, Barnett R. 2004. 'Central Asia Wars and Ethnic Conflicts: Rebuilding Failed States', Human Development Report Office Occasional Paper, (February 19, 2004). United Nations Development Programmes. Download PDF.

Rubin, Barnett R. 2000. 'The Political Economy of War and Peace in Afghanistan', World Development, Vol. 28, No. 10, pp. 1789-1803.

Rubin, Barnett R. 1999. 'Afghanistan under the Taliban', Current History, Vol. 98, No. 625.

Rubin, Barnett R. and Helena Malikyar. 2003. 'The Politics of Center-Periphery Relations in Afghanistan', Center on International Cooperation. Download PDF.

Ruttig, Thomas. 2011. 'Negotiations with the Taliban: History and Prospects for the Future’, New America Foundation. Download PDF.

Ruttig, Thomas. 2010. ‘How Tribal Are the Taleban? Afghanistan’s Largest Insurgent Movement between its Tribal Roots and Islamist Ideology', Afghanistan Analysts Network. Download PDF.

Ruttig, Thomas. 2010. 'The Ex-Taleban on the High Peace Council: A renewed role for the Khuddam ul-Furqan?', Afghanistan Analysts Network. Download PDF. 
Ruttig, Thomas. 2011. 'Negotiations with the Taliban: History and Prospects for the Future,’ New America Foundation. Download PDF.

Ruttig, Thomas. 2009. 'The Other Side: Dimensions of the Afghan Insurgency: Causes, Actors and Approaches to 'Talks', Afghanistan Analysts Network. Download PDF.

Ruttig, Thomas. 2009. 'Loya Paktia’s Insurgency: The Haqqani Network as an Autonomous Entity', in Antonio Giustozzi (ed.) Decoding the New Taliban: Insights from the Afghan Field. Hurst/Columbia University Press.

Ruttig, Thomas. 2006. 'Islamists, Leftists - and a Void in the Center: Afghanistan's Political Parties and where they came from, 1902-2006', Konrad Adenauer Stiftung Afghanistan Office. Download PDF.

Rzehak, Lutz. 2008. 'Remembering the Taliban', in Robert D Crews and Amin Tarzi (editors). The Taliban and the Crisis of Afghanistan. Cambridge, MA: Harvard University Press.

Saikal, Amin. 2009. 'The roots of the Afghan Conflict', in K. Foster (ed.), What Are We Doing in Afghanistan? Melbourne: Australian Scholarly Publishing.

Saikal, Amin. 2009. 'Afghanistan: Before and After the Cold War', in C. Chari (ed.), Superpower Rivalry and Conflict. Routledge.

Saikal, Amin. 2009. 'Afghanistan: The Unstable Strategic Bridge', Disarming Times. The Journal of Pax Christi Australia, Vol. 34, No. 4.

Saikal, Amin. 2002. 'The Role of Outside Actors', in Christine Noelle-Karimi, Conrad Schetter and Reinhard Schlagenweit (editors) Afghanistan - A Country without a State? Frankfurt am Main, Germany: IKO- Verlag fur Interkulturelle Kommunikation.

Saikal, Amin. 2002. 'Afghanistan, Terrorism, and American and Australian Responses', Australian Journal of International Affairs, Vol. 56, No. 1.

Saikal, Amin. 2000. 'The Role of Outside Actors in Afghanistan', Middle East Policy, Vol. 7, No. 4.

Saikal, Amin. 1998. 'The Rabbani Government, 1992-1996', in William Maley (editor) Fundamentalism Reborn? Afghanistan and the Taliban. New York University Press.

Saikal, Amin. 1998. ‘Afghanistan’s Ethnic Conflict’, Survival, Vol. 40, No. 2.

Saikal, Amin. 1996. 'The UN and Afghanistan: A Case of Failed Peacemaking Intervention', International Peacekeeping, Vol. 3, No. 1. 
Saikal, Amin. 1992. 'Afghanistan: Culture and Ideology under Pre-1978 Governments', Central Asian Survey, Vol. 11, No. 1.

Sarazin, Simon. 2007. 'La décision de l'intervention soviétique en afghanistan : un exemple de l'ambivalence des relations entre Moscou et les États du Sud', Outre-mers, Vol. 95, No. 354-55, pp. 133-146.

Schetter, C. 2006. 'Geopolitics and the Afghan Territory', Geographische Rundschau International Edition, 2 (4): pages 20-26.

Schetter, Conrad. 2005. 'Ethnoscapes, National Territorialisation, and the Afghan War', Geopolitics, Vol. 10, pp. 50-75.

Schetter, Conrad. 2003. Ethnizität und Ethnische Konflikte in Afghanistan. Reimer.

Schetter, Conrad. 2003. 'Ethnicity and Political Reconstruction in Afghanistan', Paper presented at the symposium: State Reconstruction and International Engagement in Afghanistan. Download PDF.

Schetter, C. and R. Glassner. 2009. 'The Changing Face of Warlordism in Afghanistan', in: H.-G. Ehrhart and C.C. Pentland (eds), The Afghanistan Challenge. Carleton University Press. Download PDF.

Schetter, C. and R. Glassner. 2009. 'Neither Functioning, nor failing of the State: Seeing Violence in Afghanistan from Local Perspectives', in S. Collmer (ed.), From Fragile State to Functioning State: Pathways to Democratic Transformation in Georgia, Kosovo, Moldova, and Afghanistan. Berlin. Download PDF.

Schetter, Conrad, Rainer Glassner and Masood Karokhail. 2007. 'Beyond Warlordism: The local Security Architecture in Afghanistan’, Internationale Politik und Gesellschaft 2: 136-153. Download PDF.

Schetter, Conrad, Rainer Glassner and Masood Karokhail. 2006. 'Understanding Local Violence: Security Arrangements in Kandahar, Kunduz and Paktia’, Amu Darya Series. Paper No. 3. Download PDF.

Schmidt, Farhana. 2010. 'From Islamic Warriors to Drug Lords: The Evolution of the Taliban Insurgency’, Mediterranean Quarterly, Vol. 21, No. 2.

Senlis Council. 2006. 'Helmand at War: The Changing Nature of Insurgency in Southern Afghanistan and its Effects on the Future of the Country.' Download PDF.

Shahrani, M. Nazif. 2009. 'Afghanistan Since 1919: From Failed Modernization and Failed-State to a Post-Taliban Militia-State', in The Islamic world in the age of Western dominance. Volume 5 of The New Cambridge History of Islam. Francis Robinson, ed. 
Shahrani, M. Nazif. 2008. 'Taliban and Talibanism in Historical Perspective', in R. D. Crews and A. Tarzi (eds). The Taliban and the Crisis of Afghanistan. Cambridge, MA: Harvard University Press.

Shahrani, M. Nazif. 2002. 'War, Factionalism, and the State in Afghanistan', American Anthropologist, Vol. 104, No. 3. September 2002, pp. 715-722.

Shahrani, M. Nazif. 2001. 'Resisting the Taliban and Talibanism in Afghanistan: Legacies of a Century of Internal Colonialism and Cold War Politics in a Buffer State', Perceptions: Journal of International Affairs, 5(4). Download PDF.

Shahrani, M. Nazif. 2000. 'The Taliban Enigma: Person-Centered Politics \& Extremism in Afghanistan', in ISIM Newsletter, 6: pp 20-21. Published by International Institute for the Study of Islam in the Modern World, University of Leiden, The Netherlands.

Shahrani, M. Nazif. 1998. 'The Future of the State and the Structure of Community Governance in Afghanistan', in William Maley (editor) Fundamentalism Reborn? Afghanistan and the Taliban. New York: New York University Press.

Shahrani, M. Nazif. 1990. 'Afghanistan: State and Society in Retrospect', In The Cultural Basis of Afghan Nationalism, edited by Edwan W. Anderson and Nancy Hatch Dupree. London and New York: Pinter Publishers, pp. 41-49.

Shahrani, M. Nazif. 1986. 'State Building and Social Fragmentation in Afghanistan: A historical Perspective', in The State, Religion, and Ethnic Politics: Afghanistan, Iran, and Pakistan. Ali Banuazizi and Myron Weiner (Eds.) Syracuse: Syracuse University Press.

Shahrani, M. Nazif. 1984. 'Causes and Context of Responses to the Saur Revolution in Badakhshan', In Revolutions and Rebellions in Afghanistan: Anthropological Perspectives. Edited by M.N. Shahrani and R.L. Canfield. Berkley, Institute of International Studies, University of California, pp. 139-169.

Shahrani, M. Nazif. 1979. 'Ethnic Relations under Closed Frontier Conditions: Northeast Badakhshan' in W. McCagg and B Silver (Eds), Soviet Asian Ethnic Frontiers. Pergamon.

Shalinsky, Audrey C. 1984. 'Ethnic reactions to the current regime in Afghanistan: A case study', Central Asian Survey, 3(4).

Shalinsky, Audrey C. 1982. 'Islam and Ethnicity: The Northern Afghan Perspective', Central Asian Survey, Vol. 1, No. 2/3 (November 1982), pp. 71-84.

Shaw, Geoff. 2007. ‘Afghanistan’s Ghosts’, Journal of Conflict Studies, Vol 27, No 1.

Sidky, H. 2007. 'War, Changing Patterns of Warfare, State Collapse, and Transnational Violence in Afghanistan: 1978-2001', Modern Asian Studies, Vol. 41, No. 4. 
Simonsen, Sven Gunnar. 2005. 'Addressing Ethnic Divisions in Post-Conflict InstitutionBuilding: Lessons from Recent Cases’, Security Dialogue, Vol. 36, No. 3.

Simonsen, Sven Gunnar. 2004. 'Ethnicising Afghanistan?: inclusion and exclusion in post-Bonn institution building', Third World Quarterly, Vol. 25, No. 4.

Singh, Iesha. 2001. 'Exploring issues of violence within the recent context of the Hazarajat, Afghanistan’, Central Asian Survey, 20:2, 195 - 227.

Smith, Graeme. 2009. 'What Kandahar's Taliban Say', in Antonio Giustozzi (ed.) Decoding the New Taliban: Insights from the Afghan Field. Hurst/Columbia University.

Snow, Chris et al. 2009. 'Conflict analysis: Farza and Kalakan districts, Kabul province', Cooperation for Peace and Unity, March 2009. Download PDF.

Spanta, Rangin Dadfar. 2005. 'Afghanistan: Nation-Building in the Shadow of the Warlords and the 'War on Terror'" in Nation-building: A Key Concept for Peaceful Conflict Transformation? Jochen Hippler (editor). London: Pluto Press.

Steinberg, Guido and Nils Wormer. 2010. 'Escalation in the Kunduz Region: Who are the Insurgents in Northeastern Afghanistan?’, SWP Comments, No. 33. PDF.

Stenersen, Anne. 2011. 'Al Qaeda's Foot Soldiers: A Study of the Biographies of Foreign Fighters Killed in Afghanistan and Pakistan Between 2002 and 2006', Studies in Conflict \& Terrorism, Vol. 34, No. 3.

Stenersen, Anne. 2010. 'The Taliban insurgency in Afghanistan - organization, leadership and worldview’, Norwegian Defence Research Establishment. PDF.

Stenersen, Anne. 2010. 'Al-Qaeda's Allies: Explaining the Relationship Between AlQaeda and Various Factions of the Taliban After 2001', New America Found. PDF.

Stenersen, Anne. 2009. 'Are the Afghan Taliban Involved in International Terrorism?', CTC Sentinel, Vol. 2, No. 9. Download PDF.

Suhrke, Astri, Torunn Wimpelmann Chaudhary, Aziz Hakimi, Kristian Berg Harpviken, Akbar Sarwari, Arne Strand. 2009. 'Conciliatory Approaches to the Insurgency in Afghanistan: An Overview’, CMI Report. Download PDF.

Sullivan, Daniel P. 2007. 'Tinder, Spark, Oxygen, and Fuel: The Mysterious Rise of the Taliban', Journal of Peace Research, Vol. 44: pp. 93-108.

Swanström, Niklas L.P. and Svante E. Cornell. 2005. 'A Strategic Conflict Analysis of Afghanistan’, Central Asia - Caucasus Institute. Download PDF.

Taliban. 2009. ‘Taliban Rules and Regulations (2009).’ [AKA ‘Laheya’]. PDF. 
Taliban. 2009. 'A Book of Rules’, The Islamic Emirate of Afghanistan (Quetta Shura). Translated by the NEFA Foundation. Download PDF.

Tapper, Richard. 1989. 'Ethnic idenities and social categories in Iran and Afghanistan', in M. Chapman, M. McDonald \& E. Tonkin (eds.) History and Ethnicity. Routledge.

Tapper, Richard. 1988. 'Ethnicity, Order, and Meaning in the Anthropology of Iran and Afghanistan', in J.-P. Digard (Ed) Le Fait Ethnique en Iran et en Afghanistan. Paris: Editions du Centre National de la Recherche Scientifique.

Tapper, Richard. 1984. 'Ethnicity and Class: Dimensions of Conflict', in Revolutions and Rebellions in Afghanistan: Anthropological Perspectives. M. Nazif Shahrani and Robert L Canfield (Eds.) University of California Berkeley.

Tapper, Richard. 1983. 'Introduction', in The Conflict of Tribe and State in Iran and Afghanistan. Richard Tapper (Ed.) New York: St. Martin’s Press.

Tariq, Mohammed Osman. 2008. 'Tribal Security System (Arbakai) in Southeast Afghanistan’, Occasional Paper no.7, Crisis States Research Centre. Download PDF.

Tarzi, Amin. 2008. 'The Neo-Taliban', in Robert D Crews and Amin Tarzi (editors). The Taliban and the Crisis of Afghanistan. Cambridge, MA: Harvard University Press.

Tarzi, Shah M. 1993. 'Afghanistan in 1992: A Hobbesian State of Nature', Asian Survey, Vol. 33, No. 2, pp. 165- 174.

Tarzi, Shah M. 1991. 'Politics of the Afghan Resistance Movement: Cleavages, Disunity, and Fragmentation’, Asian Survey, Vol. 31, No. 6, pp. 479-495.

Thruelsen, Peter Dahl. 2010. 'The Taliban in southern Afghanistan: a localised insurgency with a local objective’, Small Wars \& Insurgencies, Vol. 21, No. 2.

TLO. 2009. 'Three Years Later: A Socio-political Assessment of Uruzgan Province from 2006 to 2009. Tribal Liaison Office. Download PDF.

Trives, Sebastien. 2009. 'Loya Paktia’s Insurgency: Roots of the Insurgency in the Southeast', in Antonio Giustozzi (ed.) Decoding the New Taliban: Insights from the Afghan Field. Hurst/Columbia University Press.

Trives, Sébastien. 2006. 'Afghanistan: Tackling the Insurgency, the Case of the Southeast', Politique étrangère, January.

Upadhyay, R. 2009. 'Taliban: Its Origin and the Historical Background', South Asia Analysis Group. Read Online. 
Various Authors. 2009. Afghanistan, 1979-2009: In the Grip of Conflict. The Middle East Institute. Washington, DC. Download PDF.

Vigier, Corrina. 2009. 'Conflict Assessment: Afghanistan', American Friends Service Committee. Download PDF.

Wakil, Abdul. 1995. 'Ismail Khan: Governor of Herat Province’, in Orient, 36(1).

Wakil, Abdul. 1993. 'Ethnic disunity, linguistic diversity, sectarian dichotomy, and the Afghan current whirl', Orient, 34(4).

Waldman, Matt. 2010. 'The Sun in the Sky: The Relationship between Pakistan's ISI and Afghan Insurgents’, Crisis States Research Centre. Download PDF.

Weera, Seddiq and Allison Roberts Miculan. 2001. 'History, culture and ethnicity in Afghanistan', Federations (October 2001).

Wegener, A. 2007. 'A Complex and Changing Dynamic Afghan Responses to Foreign Intervention 1878-2006’, Land Warfare Studies Centre, Canberra. Download PDF.

Weinbaum, Marvin G. and Harder, Jonathan B. 2008. 'Pakistan's Afghan policies and their consequences', Contemporary South Asia, Vol. 16, No. 1, pp. 25-38.

Williams, Brian Glyn. 2011. 'On the Trail of the 'Lions of Islam': Foreign Fighters in Afghanistan and Pakistan, 1980-2010’, Orbis, Vol. 55, No. 2.

Williams, Brian Glyn. 2010. 'Report from the Field. General Dostum and the Mazar i Sharif Campaign: New light on the role of Northern Alliance warlords in Operation Enduring Freedom', Small Wars and Insurgencies, Vol. 21, No. 4. Download PDF.

Williams, Brian Glyn. 2008. 'Talibanistan: History of a Transnational Terrorist Sanctuary’, Civil Wars, Vol. 10, No 1, pp. 40-59.

Williams, Brian Glyn. 2008. 'Dostum: Afghanistan’s Embattled Warlord', Terrorism Monitor, Vol. VI, Issue 8.

Williams, Brian Glyn. 2007. 'Writing the Dostumname: Field Research with an Uzbek Warlord in Afghan Turkistan', Central Eurasian Studies Review, Vol. 6, No. 1/2. PDF.

Zaidi, Syed Manzar Abbas. 2008. 'The New Taliban Warlords and Organization’, Defence Against Terrorism Review, Vol. 1, No. 2.

Zeman, Phillip M. 2009. ‘Tribalism and terror’, Small Wars \& Insurgencies, Vol. 20(3). 


\section{Theses and Dissertations}

Baryalay, Haroon Jan. 2005. The jirga as a dispute resolution body and the case for its official recognition by the state. Thesis (LL. M.)--Harvard Law School.

Bleuer, Christian. 2007. Uzbeks Versus The Center: Mobilization as an Ethnic Minority in the Tajikistan and Afghanistan Civil Wars. MA Thesis, Central Eurasian Studies Department, Indiana University. Download PDF.

Coburn, Noah S. 2010. Potters and Warlords in an Afghan Bazaar: Political Mobilization, Masterly Inactivity and Violence in Post-Taliban Afghanistan. PhD dissertation, Boston University.

DeNeufville, Peter Bayon. 2006. Ahmad Shah Massoud and the genesis of the nationalist anti-Communist movement in Northeastern Afghanistan 1969-1979. Thesis (PhD.)-University of London.

Goodson, Larry Preston. 1990. Refugee-Based Insurgency: The Afghan Case. Ph.D. dissertation. The University of North Carolina at Chapel Hill.

Groh, Ty L. 2006. 'Ungoverned Spaces: the Challenges of Governing Tribal Societies', Naval Postgraduate School Thesis. Monterey, California (June 2006). Download PDF.

Lyon, Peter David Sterling. 2007. A solution for ethnic conflict: democratic governance in Afghanistan, a case study. Thesis (M.A.)--University of Manitoba. Download PDF.

Mahmood, Tariq. 2005. The Durand Line: South Asia's new trouble spot. Thesis (M.A. in National Security Affairs)--Naval Postgraduate School (U.S.). Download PDF.

Mohmand, Abdul-Qayum. 2007. American foreign policy toward Afghanistan, 19192001. Dissertation: Thesis (Ph. D.)--University of Utah. Mokhtarzada, Shahla. 1996. The Social Origins of the Neopatrimonial State in Afghanistan. Ph.D. Dissertation, University of California, Davis.

Nassimi, Azim M. 1997. An Ethnography of Political Leaders in Afghanistan. Ph.D. Dissertation, Ball State University.

Verhoeve, Sebastian. 2007. De eerste fase in de oorlog in Afghanistan. Thesis Letteren Geschiedenis (doctoraal). Utrecht. Download Word Doc. 


\section{Islam: Political Islam, Sharia, Jihad, Sects and Religious Affairs}

\section{Books}

Abou Zahab, Mariam and Olivier Roy (translated by John King) 2004. Islamist Networks: The Afghan-Pakistan Connection. New York: Columbia University Press.

Andreyev, Sergei. 2008. Sufi Illuminati: The Rawshani Movement in Muslim Mysticism, Society and Politics. Routledge.

Aquil, Raziuddin. 2009. Sufism, Culture, and Politics: Afghans and Islam in Medieval North India. Oxford University Press.

Canfield, Robert L. 1973. Faction and Conversion in a Plural Society: Religious Alignments in the Hindu Kush. Ann Arbor, MI: University of Michigan.

Centlivres, Pierre and Micheline Centlivres-Demont 2010. Afghanistan on the Threshold of the 21st Century: Three Essays on Culture and Society. Markus Wiener Publishers.

Edwards, David B. 2002. Before Taliban: Genealogies of the Afghan Jihad. Berkeley, CA: University of California Press.

Edwards, David B. 1996. Heroes of the Age: Moral Fault Lines on the Afghan Frontier. Berkeley, CA: University of California Press.

Fuller, Graham. 1991. Islamic fundamentalism in Afghanistan: Its character and Prospects. Santa Monica, CA: RAND.

Haroon, Sana. 2007. Frontier of Faith: Islam in the Indo-Afghan Borderland. Columbia University Press.

Jettmar, Karl. 2011. Religions of the Hindukush: The Pre-Islamic Heritage of Eastern Afghanistan. Orchid Press.

McChesney, R. D. 1991. Waqf in Central Asia: four hundred years in the history of a Muslim shrine, 1480-1889. Princeton, N.J.: Princeton University Press.

Olesen, Asta. 1995. Islam and Politics in Afghanistan. Richmond, Surrey: Curzon.

Roy, Olivier. 1994. Afghanistan: From Holy War to Civil War. Princeton:Darwin Press.

Roy, Olivier. 1990. Islam and Resistance in Afghanistan. Cambridge University press. 
Roy, Olivier. 1985. L'Afghanistan: Islam et modernité politique. Paris: Seuil.

Samuelsson, Jan. 1975. Islam i Afganistan-under kung Muhammed Zahir shah. En studie av moderniseringsprocessens följder för islams ställning i Afganistan. Stockholm.

\section{$\underline{\text { Articles, reports, and book chapters }}$}

Ahmed, Faiz. 2007. 'Shari'a, Custom, and Statutory Law: Comparing State Approaches to Islamic Jurisprudence, Tribal Autonomy, and Legal Development in Afghanistan and Pakistan,' Global Jurist, Vol. 7, Issue 1.

Anderson, Jon W. 1984. 'How Afghans define themselves in relation to Islam', in M. Nazif Shahrani and Robert L. Canfield (editors), Revolution and Rebellions in Afghanistan: Anthropological Perspectives. Berkeley, CA: University of California Press.

Anderson, Jon W. 1986. 'Popular mythologies and Subtle theologies: The Phenomenology of Muslim identity in Afghanistan', in Discourse and the Social Life of Meaning, edited by P. Chock and J. R. Wyman. Smithsonian Institute Press.

AREU. 2009. ‘ACBAR Presentation Notes: Shiite Personal Status Law research.’ PDF.

Barfield, Thomas. 2005. 'An Islamic State is a State Run by Good Muslims: Religion as a Way of Life not an Ideology in Afghanistan,' in R. Hefner, ed. Remaking Muslim Politics: Pluralism, Contestation, Democratization. Princeton, NJ: Princeton University Press.

Barfield, Thomas. 2004. 'Radical Islam in an Afghan Context', in Political Transition in Afghanistan: The State, Islam and Civil Society. Asia Program Report, No 122. PDF.

Basedow, Jürgen. 2005. 'Introduction (to Shari'a in Afghanistan)', in The Shari'a in the Constitutions of Afghanistan, Iran and Egypt: Implications for Private Law. Edited by Nadjma Yassari. Tubingen: Mohr Siebeck.

Borchgrevink, Kaja and Kristian Berg Harpviken. 2010. ‘Afghanistan’s religious landscape: politicising the sacred’, NOREF. Download PDF.

Borchgrevink, Kaja. 2010. 'Beyond Borders: Diversity and Transnational Links in Afghan Religious Education’, PRIO paper. Download PDF.

Borchgrevink, Kaja and Kristian Berg Harpviken. 2010. 'Teaching Religion, Taming Rebellion? Religious Education Reform in Afghanistan', PRIO Policy Brief, No. 7. Downloaded PDF. 
Borchgrevink, Kaja et al. 2007. 'Disconnected and Discounted? Religious actors and Civil Society in Post - 2001 Afghanistan’, PRIO. Download PDF.

Borchgrevink Kaja. 2007. 'Religious Actors and Civil Society in Post-2001 Afghanistan', International Peace Research Institute, Oslo. Download PDF.

Broschk, Florian. 2011. 'Inciting the Believers to Fight: A closer look the rhetoric of the Afghan jihad', Afghanistan Analysts Network. Download PDF.

Burki, Shireen K. 2011. 'The Creeping Wahhabization in Pukhtunkhwa: The Road to 9/11', Comparative Strategy, Vol. 30, No. 2.

Canfield, Robert L. 1984. 'Islamic Sources of Resistance’, Orbis 29(1): 57-71. 1984

Canfield, Robert L. 1976. 'Suffering as a religious imperative in Afghanistan', in The Realm of the Extra-human: Ideas and Actions. A. Bharati (ed.). The Hague: Mouton.

Caron, James M. 2007. 'Afghanistan Historiography and Pashtun Islam: Modernization Theory’s Afterimage,’ History Compass, 5/2 (2007): 314-329.

Centlivres, Micheline, Pierre Centlivres, Mark Slobin. 1971. 'A Muslim Shaman of Afghan Turkestan', Ethnology, Vol. 10, No. 2, pp. 160-173.

Christensen, Asger. 1988. 'When Muslim identity has different meanings: Religion and politics in contemporary Afghanistan', in Islam: State and Society. Klaus Ferdinand and Mehdi Mozaffari (editors). London: Curzon Press.

Cornell, Svante E. 2005. “Taliban Afghanistan: A True Islamic State?” In The Limits of Culture: Islam and Foreign Policy, ed. Brenda Shaffer. Cambridge: MIT Press.

Dorronsoro, Gilles. 2003. “Le conflit entre ‘éduqués’ et oulémas en Afghanistan.” In Guerres et sociétés : États et violence après la Guerre froide, eds. Perre Hassner and Roland Marchal. Paris : Karthala.

Dorronsoro, Gilles. 2001. 'Les Oulémas Afghans au XX ${ }^{\mathrm{e}}$ siècle : Bureaucratisation, contestation et genèse d'un Etat Clérical', Arch. de sciences soc. des religions, Vol. 115.

Dupree, L. 1979. 'Further Notes on Taqiyya: Afghanistan', JAOS, Vol. 99, pp. 680-82.

Dupree, Louis. 1976. 'Saint cults in Afghanistan', South Asia Series / American Universities Field Staff. Vol. 20(1), p. 1-26.

Edwards, David B. 1986. 'The evolution of Shi'i political dissent in Afghanistan', in J. Cole and N. Keddie (editors), Shi'ism and Social Protest. Yale University Press. 
Edwards, David B. 1993. 'Summoning Muslims: print, politics, and religious ideology in Afghanistan’, Journal of Asian Studies, 52(3).

Emadi, Hafizullah. 2000. 'Praxis of taqiyya: perseverance of Pashaye Ismaili enclave, Nangarhar, Afghanistan', Central Asian Survey, 19(2), pp. 253-264.

Freeman, Christopher P. 2002. 'Dissonant Discourse: Forging Islamist States through Secular Models: The Case of Afghanistan’, Cambridge Review of International Affairs, Vol. 15, No. 3.

Ghani, Ashraf. 1983. 'Disputes in a Court of Sharia, Kunar Valley, Afghanistan, 18851890’, International Journal of Middle East Studies, Vol. 15, No. 3.

Ghani, Ashraf. 1987. 'Afghanistan: Islam and Counterrevolutionary Movements', in Islam in Asia: Religion, Politics, and Society. J. Esposito (ed.). Oxford University Press.

Ghani, Ashraf. (1978) 'Islam and state-building in a tribal society-Afghanistan: 18801901’, Modern Asian Studies, Vol 12, No 2, pp 269-284.

Green, Nile. 2008. 'Tribe, Diaspora, and Sainthood in Afghan History', The Journal of Asian Studies, Vol. 67, No. 1, pp. 171-211.

Haqqani, Hussein. 2007. 'Afghanistan’s Islamist Groups’ in Current Trends in Islamist Ideology. Edited by Hussain Haqqani et al. Volume 5. Hudson Institute. Download PDF.

Kamali, Mohammad Hashem. 2005. 'Islam and its Sharica in the Afghan Constitution 2004 with Special Reference to Personal Law', in The Shari'a in the Constitutions of Afghanistan, Iran and Egypt. Edited by Nadjma Yassari. Tubingen: Mohr Siebeck.

Kopecky, Lucas-Michael. 1982. 'The Imami Sayyed of the Hazarajat: the maintenance of their elite position', Folk, Vol. 24, pp. 89-110.

Lau, Martin. 2010. 'Islamic law and the Afghan legal system', LSE Research Online. Download PDF.

Lizzio, Kenneth. 2006. 'The Naqshbandi/Saifiyya Battle for Islamic Tradition', The Muslim World, Vol. 96.

Malikyar, H. 1997. 'Development of family law in Afghanistan: The roles of the Hanafi Madhhab, customary practices and power politics', Central Asian Survey, Vol.16, No. 3.

Marsden, Magnus. 2009. 'Talking the Talk: Debating Debate in Northern Afghanistan', Anthropology Today, Vol. 25 No. 2.

Mendoza, Kristin (n.d.) 'Islam and Islamism in Afghanistan', Afghan Legal History Project, Harvard Law School. Download PDF. 
Naby, Eden. 1994. 'The Changing role of Islam as a Unifying Force in Afghanistan', in The Politics of Social transformation in Afghanistan, Iran, and Pakistan. Ali Banuazizi and Myron Weiner (editors). NY: Syracuse University Press.

Niyozov, Sarfaroz. 2003. 'Evolution of the Shi'a Ismaili Tradition in Central Asia', The Institute of Ismaili Studies. Download PDF.

Noelle, Christine. 1995. 'The anti-Wahhabi reaction in nineteenth-century Afghanistan', The Muslim World, Volume 85, Issue 1-2.

NPWJ. 2009. 'Afghanistan’s Shi’a Personal Status Law: Analysis’, No Peace Without Justice. Download PDF.

Oates, Lauryn. 2009. 'A Closer Look: The Policy and Law-making Process Behind the Shiite Personal Status Law’, Afghanistan Research and Evaluation Unit. Download PDF.

Rahmani, Ahmad Idrees. 2006. 'The Role of Religious Institutions in Community Governance Affairs: How are Communities Governed Beyond the District Level?’, CPS International Policy Fellowship Program. Download PDF.

Rahmani, Ahmad Idrees. 2006. 'The Role of Religious Leaders in the Provision of Local Services in Afghanistan’, CPS International Policy Fellowship Program. Download PDF.

Rieck, Andreas. 1997. 'Afghanistan's Taliban: An Islamic Revolution of the Pashtuns’ in Orient, Vol. 38, No. 1.

Roy, Olivier. 1998. 'Has Islamism a Future in Afghanistan?', in William Maley (editor) Fundamentalism Reborn? Afghanistan and the Taliban. New York University Press.

Roy, Olivier. 1994. 'Afghanistan: Jihad and Traditional Society', in The Failure of Political Islam. Cambridge: Cambridge University Press.

Roy, Olivier. 1993. 'Afghanistan: An Islamic war of resistance', in Fundamentalisms and the state. Martin Marty and R. S. Appleby (eds). Chicago: University of Chicago Press.

Roy, Olivier. 1983. 'Sufism in the Afghan resistance', Central Asian Survey, 2(4).

Rubin, Barnett R. 1997. 'Arab Islamists in Afghanistan', in Political Islam: Revolution, Radicalism or Reform? John Esposito (editor). Boulder, CO: Lynne Rienner Press.

Schmeidl, Susanne. 2007. 'Collaborating with Religious Actors in Afghanistan', in Role and Meaning of Religion and Spirituality in Development-Cooperation. Berne: Swiss Agency for Development Cooperation. 
Seleny, Anna. 2007. 'Islam and the Transformative Power of Tradition', in Building State and Security in Afghanistan. Edited by Wolfgang Danspeckgruber. Woodrow Wilson School of Public and International Affairs. Download PDF.

Shahrani, M. Nazif. 1991. 'Local Knowledge of Islam and Social Discourse in Afghanistan and Turkistan in the Modern Period', In Turko-Persia in HistoricalPerspective, edited by Robert L. Canfield. Cambridge University Press.

Shahrani, M. Nazif. 1984. 'Introduction: Marxist 'Revolution' and Islamic Resistance in Afghanistan', In Revolutions and Rebellions in Afghanistan: Anthropological

Perspectives. Edited by M. N. Shahrani and R. L. Canfield. University of California.

Shalinsky, Audrey C. 1990. 'The significance of Islam in pre-1978 Northern Afghanistan: An Urban Uzbek example’, Central Asian Survey, Volume 9, Issue 4, pp. 99 - 108.

Shalinski, Audrey C. 1982. 'Islam and Ethnicity: The Northern Afghan Perspective', Central Asian Survey, Vol. 1, No. 2/3 (November 1982), pp. 71-84.

Sharma, Prakhar. 2009. 'Role of Relion in Afghan Politics: Evolution and Key Trends', in Renewal and Resistance in the Muslim World. Stimson Center. Download PDF.

Sidky, M. H. 1990. 'Malang, Sufis, and Mystics: An Ethnographic and Historical Study of Shamanism in Afghanistan', Asian Folklore Studies, Volume 49, pp. 275-301.

Snider, Nancy. 1968. 'Mosque Education in Afghanistan’, The Muslim World, 58(1).

Tariq, Mohammed Osman et al. 2011. 'Building Trust and Institutions - Religious Institution-Building in Afghanistan: An Exploration’, PRIO Policy Brief 2. PDF.

Tariq, Mohammed Osman. 2011. 'Religious Institution Building in Afghanistan: An Exploration’, PRIO Paper. Download PDF.

Tarzi, Amin and Helena Malikyar. 2000. 'The Jilani Family of Afghanistan', Journal of the History of Sufism, Vol. 1, No. 2

USAID. 2009. 'Shiite Personal Status Law: English Translation', USAID. Downoad PDF.

Wardak, Miwais, Idrees Zaman and Kanishka Nawabi. 2007. 'The Role and Functions of Religious Civil Society in Afghanistan Case Studies From Sayedabad \& Kunduz', Research and Advocacy Department Cooperation for Peace And Unity. Download PDF.

\section{Dissertations and Theses}

al-Amri, Abdullah Sager. 1990. The doctrine of jihad in Islam and its application in the context of the Islamic jihad movement in Afghanistan, 1979-1988. Thesis (Ph. D.)-University of Idaho. 
Koepke, Bruce E. 2002. The impact of political Islam on cultural practices in Badakhshan, Afghanistan, during the Taliban era. Thesis (Ph.D.)--Australian National University.

McChesney, R. D. 1973, 1978. Waqf at Balkh: a study of the endowments at the shrine of ‘li Ibn Abi Talib. Dissertation Thesis--Princeton University.

Wheelock, Philippe. 2005. Striving in the Sufi way: Jihad, peace and political legitimacy in Afghanistan. MA thesis. University of Colorado at Boulder.

Wieland-Karimi, Almut. 1997, 1998. Islamische Mystik in Afghanistan : die strukturelle Einbindung der Sufik in die Gesellschaft. Stuttgart : Steiner, 1998. Series ( Beiträge zur Südasienforschung ; Bd.182). Thesis (Ph.D.)-Humboldt-Universität, Berlin 1997. 


\section{State-Building: The International Community, Reconstruction, Security, Economy, Government, and Development}

\section{$\underline{\text { Books }}$}

Alexander, Chris. 2011. The Long Way Back: Afghanistan's Quest for Peace. Harper.

Barakat, Sultan (editor). 2004. Reconstructing War-torn Societies: Afghanistan. New York: Palgrave Macmillan.

Bennis, Phyllis. 2009. Ending the US War in Afghanistan: A Primer. Olive Branch Pr.

Bird, Tim and Alex Marshall. 2011. Afghanistan: How the West Lost Its Way. Yale University Press.

Block, Jeremy S. 2009. Embracing the Occupiers: Conversations with the Future Leaders of Afghanistan and Iraq. Praeger.

Bolton, Matthew. 2010. Foreign Aid and Landmine Clearance: Governance, Politics and Security in Afghanistan, Bosnia and Sudan. I. B. Tauris.

Caldwell, Dan. 2011. Vortex of Conflict: US Policy toward Afghanistan, Pakistan, and Iraq. Stanford Security Studies.

Carlton-Ford, Steven and Morten G. Ender (editors). 2010. The Routledge Handbook of War and Society: Iraq and Afghanistan. Routledge.

Christensen, Asger. 1995. Aiding Afghanistan: the Background and Prospects for Reconstruction in Fragmented Society. Copenhagen: NIAS Press.

Danspeckgruber, Wolfgang and Robert P. Finn (editors). 2010. Building State and Security in Afghanistan. Lynne Rienner Publishers.

Dobbins, J. F. 2008. After the Taliban: Nation-Building in Afghanistan. Potomoc Books.

Donini. Antonio, Norah Niland and Karin Wermester (editors). 2004. Nation-building Unraveled? Aid, Peace and Justice in Afghanistan. Bloomfield, CT: Kumarian Press.

Dupaigne, Bernard and Gilles Rossignol. 2002. Le carrefour afghan. Paris : Gallimard, Folio-Le Monde actuel. 
Dupaigne, Bernard. 2002. Afghanistan, rêve de paix, Paris: Buchet-Chastel.

Ehrhart, Hans-Georg and Charles C. Pentland. 2009. The Afghanistan Challenge: Hard Realities and Strategic Choices. School of Policy Studies Queen's University.

Entezar, Ehsan M. 2010. Afghanistan 101: Understanding Afghan Culture. Xlibris.

Gannon, James. 2011. Obama's War: Avoiding a Quagmire in Afghanistan. Potomac Books.

Girardet, Edward et al (eds.) 2004. Afghanistan: Essential Field Guide to Humanitarian and Conflict Zones. Media Action International.

Hanifi, Shah Mahmoud. 2008. Connecting Histories in Afghanistan: Market Relations and State Formation on a Colonial Frontier. Columbia University Press. Read online.

Hayes, Geoffrey and Mark Sedra (Editors). 2008. Afghanistan: Transition Under Threat. Wilfred Laurier University Press.

Herold, Marc. 2005. "Modernizing" Afghanistan. Monroe, ME: Common Courage Press.

Hill, Matthew Alan. 2001. Democracy Promotion and Conflict-Based Reconstruction:

The United States \& Democratic Consolidation in Bosnia, Afghanistan \& Iraq.

Routledge.

Hussain, Imtiaz. 2010. Afghanistan, Iraq, and Post-conflict Governance: Damoclean Democracy? Brill Academic Publishers.

Hynek, Nik and Péter Marton (editors). 2011. Statebuilding in Afghanistan:

Multinational Contributions to Reconstruction. Routledge.

Johnson, Chris, and Jolyon Leslie. 2005. Afghanistan: The Mirage of Peace. Zed Books.

Krishnappa, V. and P. Singh (eds). 2009. Saving Afghanistan. Academic Foundation.

Maley, William. 2007. Rescuing Afghanistan. London: Hurst \& Company.

Marsden, Peter. 2009. Afghanistan - Aid, Armies and Empires. I. B. Tauris.

Mason, Whit (editor). 2011. The Rule of Law in Afghanistan: Missing in Inaction. Cambridge University Press.

Montgomery, John D. 2007. Beyond Reconstruction In Afghanistan. Palgrave.

Montgomery, John D. and Dennis A. Rondinelli (editors). 2004. Beyond Reconstruction in Afghanistan: Lessons from Development Experience. New York: Palgrave Macmillen. 
Narwan, Sultan Hamid. 2006. Afghanistan: A Buffer State in Changing Buffer Systems. European University Press.

Nojumi, Neamatollah, Dyan Mazurana, Elizabeth Stites. 2008. After the Taliban: Life and Security in Rural Afghanistan. Rowman \& Littlefield Publishers.

O'Hanlon, Michael and Hassina Sherjan. 2010. Toughing It Out in Afghanistan. Brookings Institution Press.

Omidian, Patricia. 2010. When Bamboo Bloom: An Anthropologist in Taliban's Afghanistan. Waveland Press.

Pirseyedi, Bobi. 2000. The small arms problem in Central Asia: features and implications. Geneva: United Nations Institute for Disarmament Research.

Reder, Christian. 2003. Afghanistan, fragmentarisch. Springer.

Rotberg, Robert I. (editor). 2007. Building a New Afghanistan. Brookings Institute Press.

Saikal, Amin (editor). 2011. The Afghanistan Conflict and Australia's Role. Melbourne University Press

Schmitt, Michael A. (Ed). 2009. The War in Afghanistan: A Legal Analysis. Naval War College Press.

Sherzad, Haroon Rashid. 2009. A Broadcasting Model for Afghanistan: Based on Its National Development. VDM Verlag.

Stewart, Lyle (ed.). 2009. Afghanistan and Canada: Is There an Alternative to the War? Black Rose Books.

Tondini. Matteo. 2010. Statebuilding and Justice Reform: Post-Conflict Reconstruction in Afghanistan. Routledge.

Tripathi, D. 2010. Overcoming the Bush Legacy in Iraq and Afghanistan. Potomac Books.

Warnock, John W. 2008. Creating a Failed State: The U.S. and Canada in Afghanistan. Fernwood Publishing.

Williams, M.J. 2011. The Good War: NATO and the Liberal Conscience in Afghanistan. Palgrave Macmillan.

Williamson, Myra. 2009. Terrorism, war and international law: the legality of the use of force against Afghanistan in 2001. Ashgate. 
Zakheim, Dov S. 2011. A Vulcan's Tale: How the Bush Administration Mismanaged the Reconstruction of Afghanistan. Brookings Institution Press.

\section{$\underline{\text { Reports, articles, and book chapters }}$}

ACBAR. 2008. 'The Afghanistan Pilot Participatory Poverty Assessment.' Link to PDFs. ActionAid Afghanistan and ELBAG. 2007. 'Gaps In Aid Accountability - A Study of NSP Finances.’ Download PDF.

Adeny, Katharine. 2008. 'Constitutional Design and the Political Salience of "Community” in Afghanistan: Prospects for the Emergence of Ethnic Conflicts in PostTaliban Afghanistan’, Asian Survey, Vol. 48, Issue 4, pp. 535-557.

AAN. 2009. 'Polling Day Fraud in the Afghan Elections', Afghanistan Analysts Network report. Download PDF.

ACID. 2011. 'In It for the Long Haul?: Australia's Aid to Afghanistan', Australian Council for International Development. Download PDF.

Adlparvar, Naysan. 2010. 'Development in conflict: the politicisation of British aid to Afghanistan’, Institute of Development Studies.

Amiri, Ali and Abdul Jalil Benish. 2010. 'The First Experience: Voting Patterns and Political Alignments in Wolesi Jirga (2005-2010)’, Afghanistan Watch. PDF.

ANSO. 2011. 'Quarterly Data Report, Quarter 1', Afghanistan NGO Safety Office. Download PDF.

ANSO. 2010. 'ANSO Quarterly Data Report, Q.4 2010’, The Afghanistan NGO Safety Office. Download PDF.

Ahmed, Samina. 2001. 'State and Society in Afghanistan', IGD Occasional Paper, No. 29. Download PDF.

AIAS. 2009. 'Afghanistan’s Other Neighbors: Iran, Central Asia and China Conference Report', Organized by the American Institute of Afghanistan Studies and the Hollings Center for International Dialogue. Istanbul, Turkey. July 2008. Download PDF.

Akrami, Mary. 2009. 'How to Bury the Hatchet: Efforts to Reconcile', Swedish Committee for Afghanistan Conference: Peace Building in Afghanistan. Download PDF.

Allen, Nigel J.R. 2003. 'Rethinking governance in Afghanistan', Journal of International Affairs, Spring 2003, vol. 56, no. 1. 
Allen, Nigel J. R. 2001. 'Defining People and Place in Afghanistan', Post-Soviet Geography and Economics, Vol. 42, No. 8.

Allan, Nigel J.R. 1991. 'From Autarky to Dependency: Society and Habitat Relations in the South Asian Mountain Rimland', Mountain Research and Development, Vol. 11, No. 1, Transformation of Mountain Environments (TOME). Part Two. (Feb., 1991), pp. 65-74.

Altai Consulting. 2008. 'Development in Afghanistan: Key Achievements 2001-2008, ANDS, Paris Conference.’ Download PDF.

ANDS. 2008. ‘Afghanistan National Development Strategy (2008-2013). Download PDF.

Aras, Bulent and Sule Toktas. 2008. 'Afghanistan's Security: Political Process, StateBuilding and Narcotics’, Middle East Policy, Vol. 15 Issue 2.

Archer, Toby et al. 2009. 'Afghanistan's Hard Summer: The Impact on European Troop Contributing Nations', The Finnish Institute of International Affairs. Download PDF.

Arens, H. 1975. 'Die Energieversorgung in Afghanistan’, Afghanistan Journal, Vol. 2(1).

AREU and The World Bank. 2004. Subnational Administration in Afghanistan: Assessment and Recommendations for Action. AREU and the World Bank.

AREU and The World Bank. 2004. 'A Guide to Government in Afghanistan', AREU and the World Bank. Download PDF.

AREU. 2009. 'Proceedings of the Land Conflict Workshop held on 8 April 2009', Afghanistan Research and Evaluation Unit. Download PDF.

AREU. 2005. 'Election Observation Report', AREU. Download PDF.

AREU. 2004. 'A Guide To Government In Afghanistan: Faryab Province’, AREU. PDF.

AREU. 2004. ‘A Guide To Government In Afghanistan: Badakshan’, AREU. PDF.

AREU. 2004. 'A Guide To Government In Afghanistan: Herat Province’, AREU. PDF.

Armytage, Livingston. 2007. 'Justice in Afghanistan: Rebuilding Judicial Competence After the Generation of War’, Educating Judges. Download PDF.

Atabay, Tomris. 2007. 'Prisoners and their Social Reintegration', UNODC. PDF.

Atmar, Mohammed Haneef. 2001. 'Politicisation of Humanitarian Aid and Its Consequences for Afghans’, Disasters, Vol. 25, No. 4. 
Ayub, Fatima and Sari Kouvo. 2008. 'Righting the course? Humanitarian intervention, the war on terror and the future of Afghanistan', International Affairs, Vol 84, No. 4.

Azarbaijani-Moghaddam, S., C. Schetter and S. Schmeidl. 2002. 'The Transition from Relief to Development from a Human Security Perspective: Afghanistan', Report to the UN Commission on Human Security.

Baitemann, Olga. 1990. 'NGOs and the Afghan War: the politicization of humanitarian aid', Third World Quarterly, 12(1) January 1990.

Bajraktari, Yll and Christina Parajon. 2008. 'Media and Conflict: Afghanistan as a Relative Success Story’, United States Institute of Peace, Special Report 198. PDF.

Banerjee, Nipa. 2009. 'Afghanistan: No Security, No Governance', Policy Options, November. Download PDF.

Barakat, Sultan. 2008. 'Understanding Afghanistan’, DFID, The Recovery and Development Consortium. Download PDF.

Barakat, S. and A. Strand. 1995. 'Rehabilitation and reconstruction of Afghanistan: a challenge for Afghans, NGOs and the UN', Disaster Prevention and Management, 4(1).

Barfield, Thomas. 2010. 'Rebuilding Afghanistan', in Ethnicity, Authority, and Power in Central Asia: New Games Great and Small. Edited by Robert L. Canfield and Gabriele Rasuly-Paleczek. Routledge.

Barfield, Thomas, N. Nojumi, and J. A. Their. 2006. 'The Clash of Two Goods: State and Non-State Dispute Resolution in Afghanistan', USIP. Download PDF.

Barfield, T. 2008. 'The Roots of Failure in Afghanistan', Current History, December.

Barfield, Thomas. 2008. 'Culture and Custom in Nation-Building: Law in Afghanistan', Maine Law Review, Vol. 60, No. 2.

Barfield, Thomas. 2006. 'Informal Dispute Resolution and the Formal Legal System in Contemporary Northern Afghanistan’, United States Institute of Peace. Download PDF.

Barfield, Thomas. 2003. 'Afghan Customary Law and Its Relationship to Formal Judicial Institutions’, United States Institute of Peace. Download PDF.

Barfield, Thomas. 2006. 'Informal Dispute Resolution and the Formal Legal System in Contemporary Northern Afghanistan’, USIP. Download PDF.

Barikzai, Naweed. 2010. 'Afghan Parliamentary Process: democratically destabilizing', CAPS. Download PDF. 
Barno, David W. 2009. 'Senate Armed Services Committee Testimony.' Download PDF.

Barry, Michael. 2011. ‘Kabul’s Long Shadows: Historical Perspectives’, Liechtenstein Institute. Download PDF.

Barry, Charles L. and Samuel R. Greene. 2009. 'What Democracy for Afghanistan? An Analysis Utilizing Established Norms and Five Non-Western Case Studies', Center for Technology and National Security Policy, National Defense University. Download PDF.

Bauck, P. and A. Strand. 2009. 'Strengthening Nordic development cooperation in and with Afghanistan’, Norwegian Agency for Development Cooperation. Download PDF.

Beall, Jo and Daniel Esser. 2005. 'Shaping Urban Futures: Challenges to Governing and Managing Afghan Cities’, AREU. Download PDF.

Beath, Andrew, et al. 2011. 'Winning Hearts and Minds? Evidence from a Field Experiment in Afghanistan’, MIT Political Science Department Research Paper. Link.

Bechhoefer, W. 1977. 'The role of squatter housing in the urbanization of Kabul Afghanistan Journal, Vol. 4, Issue 1, pp. 3-8.

Bechhoefer, W. 1976. 'Serai Lahori. Traditional housing in the old city of Kabul', Afghanistan Journal, Vol. 3, Issue 1, pp. 3-15.

Behr, Timo. 2011. 'Germany and Regional Command-North: ISAF's Weakest Link?', in Statebuilding in Afghanistan: Multinational Contributions to Reconstruction. Edited by Nik Hynek and Péter Marton. Routledge.

Belasco, Amy. 2007. 'The Cost of Afghanistan and Other Global War on Terror Operations since 9/11', Congressional Research Service. Download PDF.

Benard, Cheryl and Nina Hachigian (editors). 'Democracy and Islam in the new constitution of Afghanistan’, RAND Conference Proceedings. Download PDF.

Benish, A. Jalil. 2007. 'Transitional Justice in Afghanistan: End or New Beginning? An Analysis on the Implications of Transitional Justice on Afghanistan's Passage towards Stability', $20^{\text {th }}$ February 2007. Unpublished.

Benson, Stephen. 2009. 'The MAGAI ${ }^{\mathrm{TM}}$ Construct and the Northern Distribution Network: A Report of the CSIS Project on the Northern Distribution Network in Afghanistan', CSIS. Download PDF.

Bergen, Peter. 2007. ‘House Committee on Foreign Affairs Testimony.’ Read Online.

Bennett, Jennifer (ed.). 2006. 'Working Series on Traditional Societies and Democracy: An Analytical Report', Heinrich Boll Stiftung. 
Betz, David and Anthony Cormack. 2009. 'Wars Amongst the People: Iraq, Afghanistan and British Strategy’, Orbis, Spring 2009, Volume 53, Number 2.

Bezhan, Faridullah. 2006. 'Afghanistan's Parliamentary Election: Towards the Path of Democracy’, Conflict, Security and Development, Volume 6, Number 2: pages 231-239.

van Bijlert, Martine. 2010. 'Who Controls the Vote? Afghanistan's Evolving Elections', Afghanistan Analysts Network. Download PDF.

van Bijlert, Martine. 2010. ‘Untangling Afghanistan’s 2010 Vote: Analysing the electoral data', Afghanistan Analysts Briefing Paper, No. 3. Download PDF.

van Bijlert, Martine. 2010. 'Imaginary Institutions: State-Building in Afghanistan', in Doing Good or Doing Better: Development Policies in a Globalising World. Monique Kremer et al. (eds). Amsterdam University Press.

van Bijlert, Martine. 2009 'How to Win an Afghan Election; Perceptions and Practices', Afghanistan Analysts Network. Download PDF.

van Bijlert, Martine. 2009. 'Between Discipline and Discretion: Policies Surrounding Senior Subnational Appointments’, AREU. Download PDF.

Boeson, Inger W. 2004. 'From Subjects to Citizens: Local Participation in the National Solidarity Programme (NSP)’, AREU. Download PDF.

Boetig, Bradley. 2009. 'The 800-Pound Gorilla: The Interrelationship of Culture, Economics, and Security in Afghanistan’, Small Wars Journal, August 2009. PDF.

Bolton, Matthew. 2008. 'Goldmine? A Critical Look at the Commercialization of Afghan Demining’, LSE Research Paper 01/2008. Download PDF.

Borchgrevink, Kaja. 2009. 'Negotiating Justice Sector Reform in Afghanistan', Crime, Law and Social Change, Vol. 51, No. 2.

Borchgrevink, Kaja. 2009. ‘Afghanistan: Justice Sector Reform', in Oliver P. Richmond, Edward Newman \& Roland Paris, eds, New Perspectives on Liberal Peacebuilding. Tokyo: United Nations University Press.

Braithwaite, Rodric. 2009. 'Afghan Diary’, Survival, Vol. 51, No. 1.

Brick, Jennifer. 2008. 'The Political economy of Customary Village Organizations in Rural Afghanistan', Central Eurasian Studies Society, Washington, DC. Download PDF.

Buchholz, Benjamin. 2007. 'Thoughts on Afghanistan's Loya Jirga: A Myth?', Asien, Vol. 104 (July 2007), pp. 23-33. Download PDF. 
Burke, Edward. 2010. 'Spain’s War in Afghanistan’, FRIDE Policy Brief, No. 23. Download PDF.

Burrough, Mark A. 2009. 'A Historical Case Study of U.S. Strategy Towards Afghanistan’, US Army War College. Download PDF.

Byman, Daniel. 'Talking with Insurgents: A Guide for the Perplexed', The Washington Quarterly, Vol. 32, No. 2. Download PDF.

Byrd, William A. and Stephane Guimbert. 2009. 'Public Finance, Security, and Development: A Framework and an Application to Afghanistan', World Bank Policy Research Working Paper Series. Link to PDF.

Caldararo, Niccolo Leo. 2010. 'America in Afghanistan: Naivete, Greed and Good Intentions: An Anthropological View.’ Link to PDF.

Canadian Consortium on Human Security. 2007. 'The Delivery of Humanitarian Assistance in Afghanistan: A Human Security Dilemma for Canada.' Human Security Bulletin, Vol. 5, Issue 1. PDF Link.

Carbonari, Federico and Antonella Deledda. 2008. 'Afghanistan: A Change of Course?’, Transition Studies Review, Vol. 15, No. 3.

Carlsson, Gunilla. 2009. 'Sweden’s Contribution to Peace Building in Afghanistan', Swedish Committee for Afghanistan Conference: Peace Building in Afghanistan. PDF.

Celso, Anthony N. 2010. ' Phase IV' Operations in the War on Terror: Comparing Iraq and Afghanistan', Orbis, Spring.

Chaudhuri, Rudra and Theo Farrell. 2011. 'Campaign disconnect: operational progress and strategic obstacles in Afghanistan, 2009-2011', International Affairs, Volume 87, Issue 2.

Chorev, Matan and Jake Sherman. 2010. 'The Prospects for Security and Political Reconciliation in Afghanistan: Local, National, and Regional Perspectives', Institute for Global Leadership. Download PDF.

Coburn, Noah. 2011. 'Political Economy of the Wolesi Jirga: Sources of Finance and their Impact on Representation in Afghanistan's Parliament', AREU. Download PDF.

Coburn, Noah. 2010. 'Parliamentarians and Local Politics in Afghanistan: Elections and Instability II’, AREU. Download PDF.

Coburn, Noah. 2010. 'Connecting with Kabul: The Importance of the Wolesi Jirga Election and Local Political Networks in Afghanistan’, AREU. Download PDF. 
Coburn, Noah. 2010. ‘Afghan Election, 2010: Alternative Narratives’, AREU. Download PDF.

Coburn, Noah. 2010. 'Connecting with Kabul: The Importance of the Wolesi Jirga Election and Local Political Networks in Afghanistan’, AREU. Download PDF.

Coburn, Noah and John Dempsey. 2010. 'Informal Dispute Resolution in Afghanistan' USIP Report. Download PDF.

Coburn, Noah and Anna Larson. 2009. 'Voting Together: Why Afghanistan's 2009 Elections were (and were not) a Disaster', AREU. Download PDF.

Coburn, Noah and Anna Larson. 2009. 'Patronage, Posturing, Duty, Demographics Why Afghans Voted in 2009’, AREU. Download PDF.

Coburn, Noah. 2009. 'Some Afghan Views on the Government, the International Community, and the 2009 Elections’, AREU. Download PDF.

Coburn, Noah. 2008. 'Qaum: Conceptualizing Potters in the Afghan Political Arena', Boston University. Download PDF.

Cole, Juan. 2009. 'Pakistan and Afghanistan: Beyond the Taliban', Political Science Quarterly, Vol. 124, No. 2.

Condra, Luke N. et al. 2010. 'The Effect of Civilian Casualties in Afghanistan and Iraq', NBER working paper. Download PDF.

Connolly, David. 2010. 'Participatory Research in Programme Evaluation: the Mid-term Evaluation of the National Solidarity Programme in Afghanistan', in Participatory Research Methodologies in Development and Post-Disaster/Conflict Reconstruction. Edited by R. Bowd and A. Ozerdem. London: Ashgate.

Conway, Drew. 2010. ‘Networks, Collective Action, and State Formation’, Link.

Cookman, Colin and Caroline Wadhams. 2010. 'Governance in Afghanistan: Looking Ahead to What We Leave Behind', Center for American Progress. Download PDF.

Cordesman, Anthony H. 2011. 'The Failures That Shaped (and Almost Lost) the Afghan War', CSIS. Download PDF.

Cordesman, Anthony H. 2010. 'Afghanistan: A Progress Report’, CSIS. PDFs.

Cordesman, Anthony H. 2010. 'How America Corrupted Afghanistan: Time to Look in the Mirror’, CSIS. Download PDF. 
Cordesman, Anthony H. and Jason Lemieux. 2010. 'The Afghan War: A Campaign Overview', CSIS. Download PDF.

Cordesman, Anthony and Nicholas Greenough. 2009. 'The Afghan-Pakistan War: Afghan Economics and Conditions of Life', CSIS. Download PDF.

Cordesman, Anthony H. 2008. 'The Afghanistan-Pakistan War: Measuring Success (or Failure)', CSIS report. Download PDF.

Cordesman, Anthony H. 2007. 'The Missing Metrics of "Progress" in Afghanistan (and Pakistan)’, Working Draft. CSIS. Download PDF.

Coyne, Christopher J. and Adam Pellillo. 2011. 'The Art of Seeing Like a State: StateBuilding in Afghanistan, the Congo, and Beyond.' Link to PDF.

CSIS. 2008. 'Dilemmas of Democracy: Work in Progress in Afghanistan and Pakistan', Center for Strategic and International Studies Date. Download PDF.

Cullather, Nick. 2002. 'From New Deal to New Frontier in Afghanistan: Modernization in a Buffer State', Journal of American History, Vol. 89, No. 2.

Cullather, Nick. 2002. 'From New Deal to New Frontier in Afghanistan: Modernization in a Buffer State', The Cold War as Global Conflict, International Center for Advanced Studies-New York University Working Paper \#6. Download PDF.

Dale, Catherine. 2011. 'War in Afghanistan: Strategy, Operations, and Issues for Congress', Congressional Research Service. Download PDF.

Dalili, Raz Mohammad. 2004. 'Ethnicity and Peace-Building and Reconstruction in Afghanistan’, JCAS Symposium Series, 21.

Dalton, Russell J. 2008. 'The Road to Democracy in Afghanistan', in State Building, Security, and Social Change in Afghanistan: Reflections on a Survey of the Afghan People. The Asia Foundation. Download PDF.

Dansie, Grant. 2009. ‘Enemies, Irregular Adversaries, Spoilers, Non-compliant Actors: How the Definition of Actors Influences Afghanistan Strategies', Norwegian Institute of International Affairs. NUPI Working Paper 756. Download PDF.

Danspeckgruber, Wolfgang and Robert P. Finn. 2007. 'Introduction' in Building State and Security in Afghanistan. Edited by Wolfgang Danspeckgruber. Woodrow Wilson School of Public and International Affairs. Download PDF.

Davin, Eric and Geraldine Baudienville. 2008. 'Aid effectiveness in Afghanistan, Paris Conference.’ Altai Consulting. Download PDF. 
Davin, Eric et al. 2005. 'Afghan Media 3 years after: Media and Alternative Sources of Information in Afghan Society', USAID. Download PDF.

Davis, Anthony. 2003. ‘Afghan Security Deteriorates as Taliban Regroup’, Jane’s Intelligence Review, Vol. 15, No. 5.

Debiel, Tobias, Rainer Glassner, Conrad Schetter and Ulf Terlinden. 2009. 'Local StateBuilding in Afghanistan and Somaliland ', Peace Review, Vol. 21, No. 1.

Deeks, Ashley. 2008. 'Detention in Afghanistan: The Need For an Integrated Plan', Center for Strategic and International Studies. Download PDF.

Deledda, Antonella. 2006. 'Afghanistan - The End of the Bonn Process', Transition Studies Review, Volume 13, Number 1. (May 2006).

Denissen, Marieke. 2009. 'Mutual Accountability in Afghanistan: Promoting Partnerships in Development Aid?’, AREU. Download PDF.

Department of Defense. 2009. Report on Progress Toward Security and Stability in Afghanistan January 2009', United States Department of Defense. Download PDF.

Dittmann, Andreas. 2007. 'Recent Developments in Kabul's Shar-e-Naw and Central Bazaar Districts’, Asien, 104 (Juli 2007). Download PDF.

Donini, Antonio. 2009. ‘Afghanistan: humanitarianism under threat', Feinstein International Center. Download PDF.

Donini, Antonio. 2007. 'Local Perceptions of Assistance to Afghanistan', International Peacekeeping, 14(1), pp. 158 - 172.

Donini, Antonio. 2004. 'An Elusive Quest: Integration in the Response to the Afghan Crisis’, Ethics \& International Affairs, Vol. 18, No. 2.

Dorronsoro, Gilles. 1993. 'L’aid humanitaire en Afghanistan', Cultures et Conflits, Autumn 1993.

Dorronsoro, Gilles. 1993. 'Les enjeux de l'aide en Afghanistan', Cultures \& Conflits, 11, automne 1993. Read Online.

Durkin, J. Keller. 2009. 'Authority, Legitimacy, and the Qawm: Historical Perspectives on Emergent Governance in Afghanistan’, SAMS Monograph. Download PDF.

Edwards, Ryan D. 2010. 'A Review of War Costs in Iraq and Afghanistan', NBER Working Paper Series. Link to PDF. 
Englehart, Neil A. 2010. 'A Tale of Two Afghanistans: Comparative Governance and Insurgency in the North and South’, Asian Survey, Volume 50, No. 4.

Ennis, D. 2006. 'Analysis of the electoral legal framework of Afghanistan', International Foundation for Election Systems. Download PDF.

Enterline, A. and J. Greig. 2009. 'Perfect Storms? Political Instability in Imposed Polities and the Futures of Iraq and Afghanistan', Journal of Conflict Resolution, Vol. 52, No. 6.

Enterline, Andrew J. and Michael Greig. 2008. 'The History of Imposed Democracy and the Future of Iraq and Afghanistan', Foreign Policy Analysis, Volume 4, Number 4.

Esser, Daniel. 2009. 'Postwar Political Restructuring in Freetown and Kabul: Theoretical Limits and the Test Case for Multiscalar Governance’, Critical Planning, Vol. 16.

Esser, Daniel. 2009. 'Who governs Kabul? Explaining urban politics in a post-war capital city’, Crisis States Working Paper No. 43 (series 2). Download PDF.

Esser, Daniel. 2007. 'Target Kabul: human insecurity in the Afghan capital', in Human Security for an Urban Century: Local Challenges, Global Perspectives. Ottawa: Foreign Affairs and International Trade Canada.

Etling, Bruce. (n.d.) 'Legal Authorities in the Afghan Legal System (1964-1979)', Afghan Legal History Project, Harvard Law School. Download PDF.

European Commission. 2006. 'National Indicative Programme of European Community Support 2005-2006: Afghanistan.’ Download PDF.

Evans, Anne and Yasin Osmani. 2005. 'Assessing Progress: Update Report on Subnational Administration in Afghanistan’, AREU. Download PDF.

Evans, Anne, et al. 2004. Subnational Administration In Afghanistan: Assessment And Recommendations For Action. World Bank.

Fair, C. Christine. 2011. 'Under the Shrinking U.S. Security Umbrella: India’s End Game in Afghanistan?’, The Washington Quarterly, Vol. 34, No. 2.

Fair, C. Christine. 2010. 'India in Afghanistan and Beyond: Opportunities and Constraints’, Century Foundation Report. Download PDF.

Fair, C. Christine. 2010. ‘Afghanistan’s Flawed Elections: Implications for the Insurgency', in The Afghanistan-Pakistan Theater: Militant Islam, Security \& Stability. Edited by Edited by Daveed Gartenstein-Ross \& Clifford D. May. Washington: FDD Press. Download PDF. 
Fänge, Anders. 2010. 'The State of the Afghan State', Afghanistan Analysts Network. Download PDF.

Fänge, Anders. 2009. 'The State, Conflict and International Assistance', Swedish

Committee for Afghanistan Conference: Peace Building in Afghanistan. Download PDF.

Favre, Raphy. 2006. 'Local Shura, Security and development', AIZON Publication, Kabul. Download PDF.

Favre, Raphy. 2005. 'Interface between State and Society in Afghanistan’, AIZON publication, Kabul. Download PDF.

Favre, Raphy. 2005. 'Potential Analysis of the Eastern region and Nangarhar Province', AIZON publication, Kabul. Download PDF.

Fayutkin, Dan. 2009. 'Stabilization \& Reconstruction of Nations after Military Conflict: Afghanistan and Chechnya Case Studies’, Comparative Strategy, Vol. 28, Issue 4.

Fishstein, Paul. 2010. 'Winning Hearts and Minds? Examining the Relationship between Aid and Security in Balkh Province’, Feinstein International Center. Download PDF.

Fluri, Jennifer. 2009. “"Foreign Passports Only”: Geographies of (Post)Conflict Work in Kabul, Afghanistan', Annals of the Association of American Geographers, Vol. 99(5).

Foust, Joshua. 2011. 'France in Kapisa: A Combined Approach to State-Building', in Statebuilding in Afghanistan: Multinational Contributions to Reconstruction. Edited by Nik Hynek and Péter Marton. Routledge.

Foust, Joshua. 2010. 'Post-Soviet Central Asian National Interests in Afghanistan', Century Foundation Report. Download PDF.

Fraenkel, Eran, et al. 2010. 'Afghanistan Media Assessment: Opportunities and Challenges for Peacebuilding', USIP. Download PDF.

Franco, Jennifer. 2011. 'Many Actors, Many Trials: On the Ground in Afghanistan', Western Political Science Association Annual Meeting Paper. Link to PDF.

Freeman, Christopher. 2007. 'Introduction: Security, Governance and Statebuilding in Afghanistan’, International Peacekeeping, Vol.14, No.1, January 2007, pp.1-7.

Frej, William M. and David Hatch. 2009. 'A New Approach to the Delivery of U.S. Assistance to Afghanistan', Prism, Vol. 1, No. 1. Download PDF.

Fuller, G. 2008. ‘Afghanistan and Terrorism’, New Perspectives Quarterly, Vol. 18(4). 
Gajewski, Gregory, et al. 2007. 'How War, a Tribal Social Structure, and Donor Efforts Shape Institutional Change in Afghanistan: A Case Study of the Roads Sector.' PDF.

Gall, Carlotta. 2009. 'Strategies for Enhancing Regional Security’, Swedish Committee for Afghanistan Conference: Peace Building in Afghanistan. Download PDF.

Gallenkamp, Marian. 2009. 'Afghanistan: Understanding German Objectives and Strategies', Institute of Peace and Conflict Studies. Download PDF.

Galtung, Fredrik and Martin Tisné, 2009. 'A New Approach to Postwar Reconstruction', Journal of Democracy, Volume 20 Number 4. Download PDF.

Gang, Rebecca. 2011. 'Community-Based Dispute Resolution Processes in Kabul City', AREU. Download PDF.

Gang, Rebecca. 2010. 'Community-Based Dispute Resolution Processes in Balkh Province’, AREU. Download PDF.

Ganguly, Sumit \& Nicholas Howenstein. 2009. 'India-Pakistan Rivalry in Afghanistan’, Journal of International Affairs, Vol. 63, No. 1.

Gardizi, Manija, Karen Hussmann and Yama Torabi. 2010. 'Corrupting the State or State-Crafted Corruption? Exploring the Nexus between Corruption and Subnational Governance', AREU. Download PDF.

Ghani, Ashraf. 2009. 'A Ten-Year Framework for Afghanistan: Executing the Obama Plan. .. And Beyond', A Report by the Atlantic Council. Download PDF.

Giustozzi, Antonio. 2010. 'Nation-Building Is Not for All; The Politics of Education', Afghanistan Analysts Network. Download PDF.

Giustozzi, Antonio and Orsini, Dominique. 2009. 'Centre-periphery relations in Afghanistan: Badakhshan between patrimonialism and institution-building', Central Asian Survey, Vol. 28, No. 1.

Giustozzi, Antonio. 2008. 'Afghanistan: transition without end. An analytical narrative of state-making’, Working Paper No: 40 (series 2). Download PDF.

Giustozzi, Antonio. 2003. 'Respectable warlords?: the politics of state-building in Afghanistan’, Crisis States Research Centre, Working Paper No. 33. Download PDF.

Ghufran, Nasreen. 2008. 'Afghanistan in 2007: A Bleeding Wound', Asian Survey, January/February 2008, Vol. 48, No. 1, Pages 154-163.

Ghufran, Nasreen. 2006. 'Afghanistan in 2006: The Complications of Post-Conflict Transition,’ Asian Survey, Vol. 47, Issue 1, pp. 87-98. 
Gleason, Gregory. 2011. 'Transit Agreements, Security Cooperation and Afghanistan Stabilization’, OSCE Central Asia Security Policy Brief \#5. Download PDF.

Gleason, Gregory, Reuel R. Hanks and Yury Bosin. 2009. 'Afghanistan reconstruction in regional perspective’, Central Asian Survey, Volume 28, Issue 3.

Gohel, Sajjan M. 2010. 'Iran’s Ambiguous Role in Afghanistan’, CTC Sentinel, Vol. 3, No. 3. Download PDF.

Gompelman, Geert. 2011. 'Winning Hearts and Minds? Examining the Relationship between Aid and Security in Afghanistan's Faryab Province', Feinstein International Center. Download PDF.

Goncharov, P. 2009. 'Afghanistan in the Fore of World Politics', International Affairs, 3.

Goodson, Larry and Thomas H. Johnson. 2011. 'Parallels with the Past: How the Soviets Lost in Afghanistan, How the Americans are Losing’, FPRI. Download PDF.

Government Accountability Office. 2009. ‘Afghanistan’s Security Environment.’PDF.

Government Accountability Office. 2009. 'Afghanistan: Key Issues for Congressional Oversight’, Government Accountability Office. April 2009. Download PDF.

Goodhand, Jonathan. 2008. 'Corrupting or Consolidating the Peace? The Drugs Economy and Post-conflict Peacebuilding in Afghanistan', International Peacekeeping, 15(3).

Goodhand, Jonathan. 2006. 'Conditioning Peace?: The Scope and Limitations of Peace Conditionalities in Afghanistan and Sri Lanka’, Clingendael Conflict research Unit. PDF.

Goodhand, Jonathan and Mark Sedra. 2009. 'Who owns the peace? Aid, reconstruction, and peacebuilding in Afghanistan’, Disasters, March 2009.

Goodhand, Jonathan and Mark Sedra. 2007. 'Bribes or Bargains? Peace Conditionalities and 'Post-Conflict' Reconstruction in Afghanistan,' International Peacekeeping, 14(1).

Goodhand, Jonathan and Mark Sedra. 2006. 'Bargains for Peace?; Aid, Conditionalities and Reconstruction in Afghanistan’, Clingendael Conflict research Unit. Download PDF.

Goodson, Larry. 2006. 'The Lessons of nation-building in Afghanistan', in Nationbuilding: Beyond Afghanistan and Iraq. F. Fukuyama (editor). Johns Hopkins U Press.

Goodson, Larry. 2005. 'Bullets, Ballots and Poppies in Afghanistan', Journal of Democracy, Vol. 16, No. 1, (January 2005). 
Goodson, Larry. 2003. Afghanistan's Long Road to Reconstruction', Journal of Democracy, Volume 14, Number 1.

Gordon, Stuart. 2011. 'Winning Hearts and Minds? Examining the Relationship between Aid and Security in Helmand Province', Feinstein International Center. Download PDF.

Grare, Frédéric. 2008. 'The Pakistan Piece of the Puzzle', Foreign Service Journal, Vol. 85, No. 7. Download PDF.

Grare, Frédéric. 2006. 'Pakistan-Afghanistan Relations in the Post-9/11 Era', Carnegie Papers, Number 72, October 2006. Download PDF.

Grare, Frederic, et al. 2007. 'Threats to Afghanistan's Transition', Panel Discussion, Carnegie Endowment for International Peace. Download PDF.

Haidari, M. Ashraf. 2009. 'Beyond the Elections: Key Lessons for International Peacekeeping in Afghanistan’, Journal of International Peace Operations. PDF.

Hall, Matthew. 2009. 'The Shanghai Cooperation Organisation: A Partner for Stabilising Afghanistan?’, Australian Defence College. Download PDF.

Hanif, Melanie. 2009. 'Indian Involvement in Afghanistan: Stepping Stone or Stumbling Block to Regional Hegemony?', German Institute of Global and Area Studies. PDF.

Hanifi, M. Jamil. 2004. 'Editing the Past: Colonial Production of Hegemony through the "Loya Jerga” in Afghanistan', Iranian Studies, 37(2).

Hanifi, M. Jamil. 1978. 'Cultural diversity, conflicting ideologies and transformational processes in Afghanistan', in W. Weissleder (ed.), The Nomadic Alternative: modes and models of interaction in the African-Asian deserts and steppes. The Hague: Mouton.

Harbo, Karl and Klas Marklund. 2009. 'Afghanistan: Stocktaking, May 2009’, Institute for Security and Development Policy. Download PDF.

Harpviken, Kristian Berg. 2011. 'A Peace Nation in the War on Terror: The Norwegian Engagement in Afghanistan', in Statebuilding in Afghanistan: Multinational

Contributions to Reconstruction. Edited by Nik Hynek and Péter Marton. Routledge.

Harpviken, Kristian Berg, 2010. 'Afghanistan in a Neighbourhood Perspective: General Overview and Conceptualisation’, PRIO Paper. Download PDF.

Harpviken, K. B. 2009. 'Peace Building and its Components - the State of the Art', Swedish Committee for Afghanistan Conference: Peace Building in Afghanistan. PDF. 
Harpviken, Kristian Berg. 2003. 'Afghanistan: From Buffer State to Battleground - to Bridge Between Regions?’, in James Hentz \& Morten Bøås, eds, New and Critical Security and Regionalism: Beyond the Nation State. Aldershot: Ashgate.

Harpviken, Kristian Berg, Arne Strand and Karin Ask. 2002. 'Afghanistan and Civil Society’, Chr. Michelsen Institute. Download PDF.

Hasegawa, Y. 2008. 'The United Nations Assistance Mission in Afghanistan: Impartiality in New UN Peace Operations', Journal of Intervention and Statebuilding, Vol. 2, Issue 2.

Hasnat, Syed. 2009. 'Pakistan's Strategic Interests, Afghanistan and the Fluctuating U.S. Strategy', Journal of International Affairs, Vol. 63, No. 1.

Hassanpour, Amir. 2001. 'The regional and international context: Are peace and cooperation possible?’, Federations (October 2001).

Hendricks, Beau A. 2010. 'Institutions and Organizations: Exploring the Interdependencies of Legitimacy Theory and Strategic Communication in Afghanistan', SAMS Monograph. Link to PDF.

Hess, Steve. 2010. 'Coming to terms with neopatrimonialism: Soviet and American nation-building projects in Afghanistan’, Central Asian Survey, Vol. 29, No. 2.

Himelfarb, Sheldon and Cecilia Paradi-Guilford. 2010. 'Can You Help Me Now?: Mobile Phones and Peacebuilding in Afghanistan’, USIP. Download PDF.

Hodes, Cyrus and Mark Sedra. 2007. 'The Search for Security in Post -Taliban Afghanistan’, Adelphi Paper 391. October 2007.

Hoehn, Andrew R. and Sarah Harting. 2010. 'Risking NATO: Testing the Limits of the Alliance in Afghanistan’, RAND. Download PDF.

Holland, Dana. 2010. Capacity-Building Through Policymaking: Developing Afghanistan’s National Education Strategic Plan’, AREU. Download PDF.

Hudak, David and Francisco Baez. 2009. 'Cultural Geography Modelling and Analysis in Helmand Province’, NATO. Word doc available online.

Humayoon, Haseeb. 2010. 'The Re-election of Hamid Karzai', ISW Afghanistan Report 4. Download PDF.

Humayoon, Haseeb and Marvin G. Weinbaum. 2009. 'The Intertwined Destinies of Afghanistan and Pakistan', in The Future of Afghanistan, edited by J. Alexander Thier. United States Institute of Peace. Download PDF. 
Huria, Sonali. 2009. 'Failed States and Foreign Military Intervention: The Afghanistan Imbroglio’, Institute of Peace and Conflict Studies. Download PDF.

Hynek, Nik and Jan Eichler. 2011. 'Post-Decisional and Alliance-Dependent: The Czech Engagement in Logar', in Statebuilding in Afghanistan: Multinational Contributions to Reconstruction. Edited by Nik Hynek and Péter Marton. Routledge.

IMF. 2008. 'Islamic Republic of Afghanistan: Poverty Reduction Strategy Paper Progress Report’, International Monetary Fund, February 2008. Download PDF.

International Legal Foundation. 2004. 'The Customary Laws of Afghanistan', The International Legal Foundation, September 2004. Download PDF.

Issa, Christine and Sardar M. Kohistani. 2007. 'Kabul's Urban Identity: An Overview of the Socio-Political Aspects of Development', Asien, 104 (July). Download PDF.

Jalali, Ali A. 2009. 'The Future of Security Institutions', in The Future of Afghanistan, edited by J. Alexander Thier. United States Institute of Peace. Download PDF.

Jalali, Ali A. 2007. 'Afghanistan: Regaining Momentum’, Parameters, Winter. PDF.

Jalali, Ali A. 2006. 'The future of Afghanistan', Parameters, Vol. 36, No. 1, (Spring 2006). Download PDF.

Janata, A. 1981. 'Notizen zur Bevölkerungskarte Afghanistans', Afghanistan Journal, Vol. 8, Issue 3, pp. 94-95.

Jawad, Said Tayeb. 2004. 'The New Constitution of Afghanistan', in Political Transition in Afghanistan: The State, Islam and Civil Society. Asia Program Special Report, No 122. Download PDF.

Jentsch, C. 1977. 'Die afghanische Zentralroute’, Afghanistan Journal, Vol. 4, Issue 1.

Jermalavicius, Tomas. 2007. 'Chairman's Introduction', $2^{\text {nd }}$ Annual Baltic Conference on Defence (ABC/D): NATO in Afghanistan. Download PDF.

Johnson, Thomas H. 2006. 'Afghanistan's post-Taliban transition: the state of statebuilding after war’, Central Asian Survey, 25(1), pp. 1-26.

Jones, S et al. 2008. 'The applicability of the Paris Declaration in fragile and conflictaffected situations', IDL Group. Download PDF.

Jones, Seth G. 2008. 'Afghanistan’s Growing Security Challenge’, in State Building, Security, and Social Change in Afghanistan. Download PDF.

Jones, Seth G. 2006. ‘Averting failure in Afghanistan’, Survival, Vol. 48, No. 1. 
Jones-Pauly, Christina and Neamat Nojumi. 2004. 'Balancing Relations Between Society and State: Legal Steps Toward National Reconciliation and Reconstruction of Afghanistan', The American Journal of Comparative Law, Fall 2004. Download PDF.

Kabulov, Zamir. 2003. 'Afghanistan: The Difficult Road to Recovery', International Affairs: A Russian Journal of World Politics, Diplomacy \& International Relations, Vol. 49, No. 4.

Kakar, Palwasha. 2005. 'Fine-Tuning the NSP: Discussions of Problems and Solutions with Facilitating Partners’, AREU. Download PDF.

Kalinovsky, Artemy. 2008. 'Old politics, new diplomacy: the Geneva accords and the Soviet withdrawal from Afghanistan’, Cold War History, Vol. 8, No. 3.

Kantor, Paula and Stefan Schutte. 2007. 'Target assistance to families with the least access to diverse, better-paying jobs', AREU. Download PDF.

Karokhail, Masood and Susanne Schmeidl. 2006. 'Integration of Traditional Structures into the State-building Process: Lessons from the Tribal Liason Office in Paktia', Promoting Democracy under Conditions of State Fragility; Issue 1: Afghanistan. PDF.

Katzman, Kenneth. 2009. 'Afghanistan: Politics, Elections, and Government Performance’, Congressional Research Service. Download PDF.

Katzman, Kenneth. 2011. 'Afghanistan: Post-Taliban Governance, Security, and U.S. Policy’, Congressional Research Service. Download PDF.

Katzman, Kenneth. 2009. 'Afghanistan: Government Formation and Performance’, CRS Report for Congress. Download PDF.

Kawano, Melanie. 2005. 'Neotrusteeship in Afghanistan', in Human Rights and PostWar Reconstruction. Human Rights and Human Welfare. Download PDF.

Kawano, Melanie and Amy McGuire. 2005. 'State-Building in Afghanistan', in Human Rights and Post-War Reconstruction. Human Rights and Human Welfare. Download PDF.

Kean, Thomas H. and Lee H. Hamilton. 2004. 'The 9/11 Commission Report: Final Report of the National Commission on Terrorist Attacks Upon the United States.' PDF.

Kellner, Thierry. 2009. 'La Chine et l'Afghanistan dans la période post-11 septembre, Relations internationals, No. 138.

Khalilzad, Zalmay. 2010 'Lessons from Afghanistan and Iraq', Journal of Democracy, Vol. 21, No. 3. 
Khamagaev, Alexander. 2003. 'Afghanistan: an ethnopolitical portrait - a unitary or a federal state?', Central Asia and the Caucasus, No. 4.

Khan, Ayesha R. 2010. 'Conceptualizing AfPak: The Prospects and Perils', Chatham House Programme Paper. Download PDF.

Khoja, Karim. 2009. 'Connecting a Nation: Roshan Brings Communications Services to Afghanistan’, Innovations, Winter 2009.

Kippen, Grant. 2009. 'The Long Democratic Transition', in The Future of Afghanistan, edited by J. Alexander Thier. United States Institute of Peace. Download PDF.

Kippen, Grant. 2008. 'Elections in 2009 and 2010: Technical and Contextual Challenges to Building Democracy in Afghanistan', AREU. Download PDF.

Kipping, Martin. 2010. 'Two Interventions: Comparing Soviet and US-led state-building in Afghanistan', Afghanistan Analysts Network. Download PDF.

Kirk, Thomas. 2010. 'Afghanistan: Reconciliation Plans, Tribal Leaders and Civil Society’, Small Wars Journal, Vol. 6, No. 12. Download PDF.

Kiss, Zoltan Laszlo. 2009. 'Hungarian experiences from peacekeeping in Afghanistan', Contributions to Conflict Management, Peace Economics and Development, Vol. 12(1).

Kjaernet, H. and S. Torjesen. 2008. 'Insecurity and risk assessment of the situation in Afghanistan’, Norwegian Institute for International Affairs. Download PDF.

Koehler, Jan and Christoph Zürcher. 2007. 'Assessing the Impact of Development Cooperation in North East Afghanistan’, BMZ prestudy. Download PDF.

Komano, Kinichi. 2005. 'The Role of Elections in the Peace-Building and Reconstruction of Afghanistan', Asia Pacific Review, Volume 12, Number 1, (May 2005): pages 1-16.

Kouvo, Sari. 2009. 'Rule of Law Deficits as a Security Challenge: 'Touching the Surface’’, NATO Review, May 2009. Read online.

Kouvo, Sari. 2009. 'State-building and rule of law: lessons from Afghanistan?', NDC Forum Paper No. 6, NATO Defense College. Download PDF.

Kreps, Sarah. 2008. 'When Does the Mission Determine the Coalition? The Logic of Multilateral Intervention and the Case of Afghanistan', Security Studies, Vol. 17, No. 3.

Kulesa, Łukasz and Beata Górka-Winter. 2011. 'From Followers to Leaders as "Coalition Servants": The Polish Engagement in Afghanistan', in Statebuilding in Afghanistan: 
Multinational Contributions to Reconstruction. Edited by Nik Hynek and Péter Marton. Routledge.

Kuntzsch, Félix. 2009. 'Sept ans d'engagement occidental en Afghanistan', Regard Critique- Le journal des hautes etudes internationales, vol. 4, no. 1, février 2009.

Kuntzsch, Félix. 2008. ‘Afghanistan’s Rocky Road to Modernity: Non-State Actors and Socio-Political Entities in the Process of State- and Nation-Building', Programme Paix et sécurité internationales (HEI). Download PDF.

Kuntzsch, Félix. 2008. 'Pourquoi en est-on rendu là? Sur les raisons contradictoires de l'engagement en Afghanistan', Regard Critique- Le journal des hautes études internationales, vol. 3, no. 1, mars 2008. Read online.

Kuntzsch, Félix. 2007. 'Les forces canadiennes en Afghanistan - d'une mission d'assistance à une guerre contre insurrectionnelle’, Sécurité mondiale, No. 27. PDF.

Lafraie, Najibullah. 2009. 'NATO in Afghanistan: perilous mission, dire ramifications', International Politics, Vol. 46, No. 5.

Larsen, Iselin Hebbert. 2010. 'UNAMA in Afghanistan: Challenges and Opportunities in Peacemaking, State-building and Coordination', Norwegian Institute of International Affairs. Download PDF.

Larson, Anna. 2011. 'Deconstructing "Democracy" in Afghanistan’, AREU. PDF.

Larson, Anna. 2010. ‘Democratisation and Elections’, AREU. Download PDF.

Larson, Anna. 2010. 'The Wolesi Jirga in Flux, 2010: Elections and Instability I', AREU. Download PDF.

Larson, Anna. 2010. 'Governance Structures in Nimroz Province’, AREU. PDF.

Larson, Anna. 2009. ‘Afghanistan’s New Democratic Parties: A Means to Organise Democratisation?’, AREU Briefing Paper. Download PDF.

Larson, Anna. 2009. 'Toward an Afghan Democracy? Exploring Perceptions of Democratisation in Afghanistan', AREU. Download PDF.

Larson, Anna. 2009. 'Afghanistan’s New Democratic Parties: A Means to Organise Democratisation?’, AREU. Download PDF.

Larsson, Katarina. 2008. 'A Provincial Survey of Balkh, Jowzjan, Samangan and Saripul', Swedish Committee for Afghanistan. Download PDF. 
Larsson, Katarina. 2004. 'Provincial Survey of Kunduz', Swedish Committee for Afghanistan. Download PDF.

Leader, Nicholas, Mark Duffield and Patricia Grossman. 2002. 'Review of the Strategic Framework for Afghanistan’, AREU (May 2002). Download PDF.

Le Miere, Christian. 2010. 'Kabul's New Patron? The Growing Afghan-Chinese Relationship’, Foreign Affairs, 13 April 2010.

Leonardo, Ernest. 2009. ‘Assessment of Corruption in Afghanistan’, USAID. PDF.

Leslie, Jolyon. 2009. 'Culture and Contest', in The Future of Afghanistan, edited by J. Alexander Thier. United States Institute of Peace. Download PDF.

Lieberman, Samuel S. 1980. 'Afghanistan: Population and Development in the "Land of Insolence"', Population and Development Review, Vol. 6, No. 2.

Lister, Sarah. 2007. 'Understanding State-Building and Local Government in Afghanistan', Crisis States Research Centre, Working Paper No. 14. Download PDF.

Lister, Sarah. 2006. 'Moving Forward? Assessing Public Administration Reform in Afghanistan’, AREU. Download PDF.

Lister, Sarah. 2005. 'Caught in Confusion: Local Government Structures in Afghanistan', AREU Briefing Paper, (March 2005). Download PDF.

Lister, Sarah. 2005. ‘Key Issues in Local Governance (PowerPoint)’, AREU. PDF.

Lister, Sarah and Andrew Wilder. 2007. 'State-Building at the Subnational Level in Afghanistan: A Missed Opportunity.’ Download PDF.

Lister, Sarah and Hamish Nixon. 2006. 'Provincial Governance Structures in Afghanistan: From Confusion to Vision?’, AREU Briefing Paper, (May 2006). Download PDF.

Livingston, Ian S., Heather L. Messera, and Michael O’Hanlon. 2011. 'Afghanistan Index Tracking Variables of Reconstruction \& Security in Post-9/11 Afghanistan’, Brookings. Download PDF.

Long, M. et al. 2007. 'The Relationship Between Postwar Reconstruction and Political Donations: The Case of Afghanistan and Iraq', Sociological Spectrum, Vol. 27, No. 4.

Lorentz, J.H. 1987. 'Afghan aid: the role of private voluntary organizations', Journal of South Asian and Middle East Studies, 11(1-2).

Ludin, Jawad. 2009. 'The Government's Peace Building Attempts 2001-2008', Swedish Committee for Afghanistan Conference: Peace Building in Afghanistan. Download PDF. 
Lunn, John and Ben Smith. 2010. 'The 'AfPak policy' and the Pashtuns', UK House of Commons Library. Download PDF.

Lysyshyn, Ralph and Paul Morton. 2001. 'The future: A responsible role for the international community’, Federations (October 2001).

Maass, Citha D. 2008. 'A Change of Paradigm in Afghanistan: Afghan Government Ownership Instead of Donor Priorities Source', Stiftung Wissenschaft und Politik, German Institute for International and Security Affairs. Download PDF.

Macdonald, Ingrid. 2010. 'Afghanistan's reintegration challenges: land and housing', NOREF. Download PDF.

Mahmud, Tayyab. 2010. 'Colonial Cartographies and Postcolonial Borders: The Unending War in and around Afghanistan’, Link to PDF.

Maley, William. 2011. 'Afghanistan: Grim Prospects?', in America's Challenges in the Greater Middle East: The Obama Administration's Policies. Edited by Shahram Akbarzadeh. New York: Palgrave Macmillan.

Maley, William. 2011. 'Security and Instability in Afghanistan', in CSCAP Regional Security Outlook 2011. Edited by Brian L. Job. Singapore: Council for Security Cooperation in the Asia Pacific.

Maley, William. 2011. 'The rule of law and the weight of politics: Challenges and trajectories', in The Rule of Law in Afghanistan: Missing in Inaction. Edited by Whit Mason. Cambridge University Press.

Maley, William. 2011. The Role of "International Society" in State-Building: Lessons from Afghanistan', in Enduring States in the Face of Challenges from Within and Without. Edited by Yusuke Murakami et al. Kyoto University Press.

Maley, William. 2011. 'Afghanistan in 2010: Continuing Governance Challenges and Faltering Security’, Asian Survey, Vol.51, No.1.

Maley, William. 2009. 'Afghanistan and Its Region', in The Future of Afghanistan, edited by J. Alexander Thier. United States Institute of Peace. Download PDF.

Maley, William. 2008. 'Stabilizing Afghanistan: Threats and Challenges', Carnegie Endowment for International Peace. Download PDF.

Maley, William. 2007. 'Building State and Security', in Building State and Security in Afghanistan. Edited by Wolfgang Danspeckgruber. Woodrow Wilson School of Public and International Affairs. Download PDF. 
Maley, William. 2008. 'Building Legitimacy in Post-Taliban Afghanistan', in State Building, Security, and Social Change in Afghanistan: Reflections on a Survey of the Afghan People. The Asia Foundation. Download PDF.

Maley, William. 2004. 'Political Transition in Afghanistan: The State, Religion and Civil Society', in Political Transition in Afghanistan: The State, Islam and Civil Society. Asia Program Special Report, No 122. Download PDF.

Maley, William. 2004. 'State-Building and Political Development in Afghanistan', in M. Ishii and J. Siapno (eds), Between Knowledge and Commitment. Centre for Area Studies, National Museum of Ethnology, Osaka.

Maley, William. 2004. 'State-Building and Political Development in Afghanistan', JCAS Symposium Series, 21.

Maley, William. 1997. 'The dynamics of regime transition in Afghanistan', Central Asian Survey, Vol. 16, No. 2.

Maloney, Seth M. 2005. 'Afghanistan four years on: an assessment', Parameters, vol. 35, no. 3, Autumn 2005. Download PDF.

Maloney, Seth M. 2004. 'Afghanistan: from here to eternity', Parameters, Vol. 34, No. 1 (Spring 2004). Download PDF.

Mariet D'Souza, Shanthie. 2009. 'Talking to the Taliban: Will it Ensure 'Peace' in Afghanistan?', Strategic Analysis, Vol. 33, No 2.

Marsden, Peter. 2003. 'Afghanistan: The Reconstruction Process', International Affairs, Vol. 79, No. 1.

Marshall, Alex. 2007. 'Managing Withdrawal: Afghanistan as the Forgotten Example in Attempting Conflict Resolution and State Reconstruction’, Small Wars \& Insurgencies, Vol. 18, No. 1, pp. 68-89.

Marten, Kimberly Zisk. 2002. 'Defending Against Anarchy: From War to Peacekeeping in Afghanistan’, Washington Quarterly, Vol. 26, No. 1.

Marton, Péter and Péter Wagner. 2011. 'Hungary’s Involvement in Afghanistan: Proudly Going through the Motions?', in Statebuilding in Afghanistan: Multinational Contributions to Reconstruction. Edited by Nik Hynek and Péter Marton. Routledge.

Matthews, Robert. 2009. 'Afghan Elections 2009: Milestone for Progress or Mirror of Malaise?’, Norwegian Peacebuilding Centre. Download PDF.

McCaffrey, Barry R. 2009. 'After Action Report', McCaffrey Associates. Download PDF. 
Medley, Dominic. 2010. 'The Growing Media Landscape in Afghanistan', The RUSI Journal, Vol. 155, No. 1.

Meindersma, Christina. 2007. 'Best Practices for Reconstruction and Development', 2nd Annual Baltic Conference on Defence (ABC/D): NATO in Afghanistan - Facing the Shortfalls and Measuring Success. Download PDF.

Mendel, Jonathan. 2010. 'Afghanistan, Networks and Connectivity’, Geopolitics, Vol. 15, No. 4.

Miakhel, Shahmahmood and Noah Coburn. 2011. 'Promoting Stability and Resolving Provincial Disputes in Afghanistan’, USIP. Download PDF.

Michailof, Serge. 2010. 'The challenge of reconstructing 'failed' states: What lessons can be learned from the mistakes made by the international aid community in Afghanistan?', FACTS Reports. Download PDF.

Mielke, Katja, Conrad Schetter and Andreas Wilde. 2011. 'Dimensions of Social Order: Empirical Fact, Analytical Framework and Boundary Concept’, ZEF Working Paper Series, No. 78. Download PDF.

Mielke, Katja, R. Glassner, C. Schetter and N. Yarash. 2007. 'Local Governance in Warsaj and Farkhar Districts’, Amu Darya Series Paper No. 7. Download PDF.

Mielke, Katja and Conrad Schetter. 2007. "Where Is the Village?" Local Perceptions and Development Approaches in Kunduz Province', Asien 104 (July 2007). Download PDF.

Mikser, Sven. 2011. 'Transition in Afghanistan: Assessing the security effort', NATO. Download PDF.

Millen, Raymond. 2005. 'Afghanistan: reconstituting a collapsed state', Strategic Studies Institute. Download PDF.

Miller, Laura and Robert Perito. 2004. 'Establishing the Rule of Law in Afghanistan', United States Institute of Peace Special Report \#117. March 2004.

Ministry of Rural Rehabilitation and Development and the Central Statistics Office, Kabul. 2007. 'The National Risk and Vulnerability Assessment 2005.'

Misra, Amalendu. 2009. 'Afghanistan - The Regional Dimension', in Afghanistan: Now You See Me? IDEAS Strategic Update 001. March 2009. Download PDF.

Monshipouri, Mahmood. 2003. 'NGOs and Peacebuilding in Afghanistan’, International Peacekeeping, Vol. 10, No. 1. 
Moore, Rebecca. 2010. 'NATO’s partners in Afghanistan: impact and purpose’, UNISCI Discussion Papers, No. 22. Download PDF.

Morelli, Vincent and Paul Gallis. 2008. 'NATO in Afghanistan: A Test of the Transatlantic Alliance’, CRS Report for Congress. Download PDF.

Müller, M. 2006. 'Reconstructing Afghanistan for Afghans? Reflections on the work of the Heinrich Boll Foundation in Afghanistan', Series on Promoting Democracy under Conditions of State Fragility; Issue 1: Afghanistan. Heinrich Boll Foundation. PDF.

Mukherjee, Ranjana, et al. 2007. 'Afghanistan, Building an Effective State: Priorities for Public Administration Reform’, World Bank Report.

Mukhopadhyay, Dipali. 'Warlords As Bureaucrats: The Afghan Experience', Carnegie Endowment for International Peace. Download PDF.

Mullen, Rani D. 2009. 'Afghanistan in 2008: State Building at the Precipice', Asian Survey, Vol. 49, Issue 1.

Mullen, Rani D. 2007. 'Centralization versus Decentralization: The Importance of Sequencing and Timing', in Building State and Security in Afghanistan. Edited by W. Danspeckgruber. Woodrow Wilson School of Public and International Affairs. PDF.

Murer, Tamara, Jawed Nader and Susanne Schmeidl, 2005. 'Mapping Youth Organizations in Afghanistan', Kabul: Afghan Civil Society Forum (ACSF) and Afghan Youth Coordination Agency (AYCA).

Nader, Alireza and Joya Laha. 2010. 'Iran’s Balancing Act in Afghanistan’, RAND. Download PDF.

NATO. 2009. 'Unclassified Metrics', Strategic Advisory Group. HQ ISAF NATO, April 2009. Download PDF.

NATO. 2009. ‘Afghanistan Report 2009’, NATO. Download PDF.

NATO. 2008. 'Progress in Afghanistan', Bucharest Summit 2-4 April 2008, Brussels, Belgium, NATO Public Diplomacy Division. Download PDF.

NATO. 2006. 'The London Conference on Afghanistan, 31 January - 1 February 2006. Building on Success’, Afghanistan Compact. Download PDF.

Naumann, Craig C. 2009. 'The Pashtunwali's Relevance as a Tool for Solving the “Afghan Crisis”', American Institute of Afghanistan Studies. Download PDF.

Naylor, Tristen. 2011. 'Deconstructing Development: The Use of Power and Pity in the International Development Discourse', International Studies Quarterly, Vol. 55. 
Nazem, P. and A. Quraishi. 2007. 'Relations between the Government of Afghanistan and the International Community’, 2nd Annual Baltic Conference on Defence (ABC/D): NATO in Afghanistan. Download PDF.

Neumann, Ronald E. 2009. 'Afghanistan: Looking Forward', The Afghanistan Papers, No. 1, June 2009. The Centre for International Governance Innovation. Download PDF.

Ng, Tiffany. 2010. 'China’s Role in Shaping the Future of Afghanistan', Carnegie Foundation, Policy Outlook. Download PDF.

Nixon, Hamish. 2011. 'Achieving Durable Peace: Afghan Perspectives on a Peace Process', PRIO. Download PDF.

Nixon, Hamish. 2008. 'Subnational State-Building in Afghanistan', AREU Synthesis Paper Series. Download PDF.

Nixon, Hamish. 2007. 'Aiding the State? International Assistance and the Statebuilding Paradox in Afghanistan’, AREU. Download PDF.

Nixon, Hamish and Ponzio, Richard. 2007. 'Building Democracy in Afghanistan: The Statebuilding Agenda and International Engagement,' International Peacekeeping, 14(1).

Noelle-Karimi, Christine. 2006. 'Village Institutions in the Perception of National and International Actors in Afghanistan’, Amu Darya Series, Paper No. 1. Download PDF.

Noetzel, Timo. 2011. 'The German politics of war: Kunduz and the war in Afghanistan', International Affairs, Vol. 87, Issue 2.

Nojumi, Neamat. 2004. 'The Prospects of Justice and the Political Transition of Civil Society: The Recovery Process of Afghanistan', in Political Transition in Afghanistan: The State, Islam and Civil Society. Asia Program Special Report, No 122. PDF.

Oakley, Robert B. and T.X. Hammes. 2004. 'Securing Afghanistan: entering a make-orbreak phase?’, Strategic Forum, No. 205, March 2004. Download PDF.

Office of Inspector General. 2010. 'Report of Inspection: Embassy Kabul, Afghanistan.' Download PDF.

O’Hanlon, M. 2009. 'Towards Reconciliation in Afghanistan', The Washington Quarterly, Vol. 32, No. 2. Download PDF.

O’Hanlon, M. and A. Lins du Albuquerque. 2005. 'Afghanistan Index: tracking variables of reconstruction and security in post-Taliban Afghanistan', Brookings Institute. PDF. 
O’Kane, Claire. 2007. 'Supporting the Development of Children's Groups and Networks in Afghanistan’, Children, Youth and Environments, Vol. 17, No. 1.

Oleinik, Anton. 2008. 'Lessons of Russian in Afghanistan', Society, Vol. 45, No. 1.

O’Loughlin, John, Frank D. W. Witmer, and Andrew M. Linke. 2010. 'The AfghanistanPakistan Wars, 2008-2009: Micro-geographies, Conflict Diffusion, and Clusters of Violence', Eurasian Geography and Economics, Vol. 51, No. 4.

Olson, Lara. 2006. 'Fighting for Humanitarian Space: NGOs in Afghanistan', Journal of Military and Strategic Studies, Vol. 9, Issue 1.

Omidian, Patricia A. 2009. 'Living and Working in a War Zone: An Applied Anthropologist in Afghanistan’, Practicing Anthropology, Vol. 31, No. 2.

Open Society Foundations. 2010. 'The Trust Deficit: The Impact of Local Perceptions on Policy in Afghanistan.’ Download PDF.

Oxfam. 2009. 'Smart Development in Practice: Field report from Afghanistan', Oxfam America. Download PDF.

Oxfam. 2008. ‘Afghanistan: Development and Humanitarian Priorities’, Oxfam. PDF.

Oxfam. 2007. 'Getting the fundamentals right. The early stages of Afghanistan's WTO accession process.’ Download PDF.

Oxfam. 2007. 'Submission to the House of Commons International Development Committee Inquiry 'Development Assistance in Insecure Environments: Afghanistan', Oxfam. Download PDF.

Pain, Adam and Paula Kantor. 2010. 'Understanding and Addressing Context in Rural Afghanistan: How Villages Differ and Why’, AREU. Download PDF.

Pant, V. Harsh. 2010. 'India’s challenge in Afghanistan: with power comes responsibility’, CASI Working Paper. Download PDF.

Parkinson, Sarah. 2010. 'Means to What End? Policymaking and State-Building in Afghanistan’, AREU. Download PDF.

Patel, Seema and Steven Ross. 2007. 'Breaking Point: Measuring Progress in Afghanistan’, CSIS/PCR Project, (February 27, 2007). Download PDF.

Pauli, Peter et al. 2009. 'National Risk and Vulnerability Assessment 2007/8: A profile of Afghanistan’, ICON-INSTITUTE. Kabul, October. Download PDF. 
Pavilonis, Brigid Myers. 2010. 'Fighting the Irregular War in Afghanistan: Success in Combat - Struggles in Stabilization', in The Routledge Handbook of War and Society: Iraq and Afghanistan. London: Routledge.

Peace Dividend Trust. 2007. 'Afghanistan Compact Procurement Monitoring Project', Peace Dividend Trust. Download PDF.

Pengelly, Ryan D., and Anne Irwin. 2010. 'Twenty-First Century Narratives from Afghanistan: Storytelling, Morality, and War', in The Routledge Handbook of War and Society: Iraq and Afghanistan. London: Routledge.

Perry, David. 2007. 'Contractors in Kandahar, Eh? Canada’s Real Commitment to Afghanistan’, Journal of Military and Strategic Studies, Vol. 9, Issue 4.

Pinney, Andrew. 2004. 'National Risk and Vulnerability Assessment 2003: A Stakeholder- Generated Methodology’, AREU. Download PDF.

Pistor, Marcus. 2008. ‘Afghanistan: European Involvement’, Library of Parliament Infoseries. Download PDF.

Ponzio, Richard J. 2007. 'Transforming Political Authority: UN Democratic Peacebuilding in Afghanistan’, Global Governance, Vol. 13, Issue 2, pp. 255-275.

Ponzio, Richard and Christopher Freeman. 2007. 'Conclusion: Rethinking Statebuilding in Afghanistan’, International Peacekeeping, Vol. 14, No. 1, (January 2007).

Poole, Lydia. 2011. ‘Afghanistan: Tracking Major Resource Flows, 2002-2010’, Global Humanitarian Assistance briefing paper. Download PDF.

Popal, Jelani. 2009. 'Government Strategies for National and Sub-National Institution Building’, Swedish Committee for Afghanistan Conference: Peace Building in Afghanistan. Download PDF.

Poulton, Robin Edward. 2003. 'Honour, guns and Jihad--improving childhood and communications in Afghanistan would promote peace', Conflict, Security and Development, Vol. 3, No. 3, December, pp. 407-416.

Purves, R. 2009. 'Afghanistan without poverty: a plain language guide to poverty in Afghanistan’, US Agency for International Development. Download PDF.

Qassem, Ahmad Shayeq. 2009. 'Afghanistan: Imperatives of Stability Misperceived', Iranian Studies, Vol. 42, No. 2, pp. 247-274.

Qassem, Ahmad Shayeq. 2007. 'Afghanistan-Pakistan relations: border controversies as counter-terrorist impediments’, Australian Journal of International Affairs, Vol. 61(1). 
Račius, Egdunas. 2011. 'Trials and Tribulations of the Lithuanian Participation in the NATO ISAF Mission', in Statebuilding in Afghanistan: Multinational Contributions to Reconstruction. Edited by Nik Hynek and Péter Marton. Routledge.

Rashid, Ahmed. 2009. 'Descent into Chaos: an Overview of the Last Six Years', Swedish Committee for Afghanistan Conference: Peace Building in Afghanistan. Download PDF.

Rashid, Ahmed. 2006. 'Afghanistan: Progress since the Taliban', Asian Affairs, 37(1): 31-5. (March 2006).

Ray, James. 2010. 'The Analogous Counterinsurgent: Afghanistan in Comparative Perspective’, APSA 2010 Annual Meeting Paper. Link to PDF.

Reinhard, Michael. 2010. 'Soft Power in the University: Results from Field Work in Afghanistan’, Western Political Science Association 2010 Annual Meeting. Link.

Reynolds, Andrew. 2007. 'Constitutional Engineering and Democratic Stability: The Debate Surrounding the Crafting of Political Institutions in Afghanistan', in Building State and Security in Afghanistan. Edited by W. Danspeckgruber. Download PDF.

Reynolds, Andrew. 2006. 'The Curious Case of Afghanistan', Journal of Democracy, Vol. 17, No. 2. (April 2006).

Reynolds, Andrew, Lucy Jones and Andrew Wilder. 2005. 'A Guide to Parliamentary Elections in Afghanistan', AREU. Download PDF.

Reynolds, Andrew and Andrew Wilder. 2004. 'Free, Fair or Flawed: Challenges to Legitimate Elections in Afghanistan', AREU. Download PDF.

Rich, Paul B. 2010. 'Counterinsurgency or a war on terror? The war in Afghanistan and the debate on Western strategy’, Small Wars \& Insurgencies, Vol. 21, No. 2.

Riedel, Bruce. 2010. 'Obama’s War: Prospects for the Conflict in Afghanistan and Pakistan’, The Afghanistan Papers, No. 7. CIGI. Download PDF.

Rietjens, Bas et al. 2009. 'Enhancing the Footprint: Stakeholders in Afghan Reconstruction’, Parameters Quarterly, May 2009. Download PDF.

Rietjens, Sebastiaan. 2011. 'Between Expectations and Reality: The Dutch Engagement in Uruzgan', in Statebuilding in Afghanistan: Multinational Contributions to Reconstruction. Edited by Nik Hynek and Péter Marton. Routledge.

Riphenburg, Carol J. 2007. 'Electoral Systems in a Divided Society: The Case of Afghanistan', British Journal of Middle Eastern Studies, Vol. 34, No. 1, pp. 1-21.

Riphenburg, Carol J. 2006. 'Afghanistan: Out of the Globalisation Mainstream?', Third 
World Quarterly, Volume 27, Number 3: pages 507-524. (April 2006).

Riphenburg, Carol J. 2005. 'Ethnicity and Civil Society in Contemporary Afghanistan', The Middle East Journal, Vol. 59, No. 1.

Ritchie, Holly. 2006. 'Aid effectiveness in Afghanistan: At a Crossroads', ACBAR Briefing Paper, No. 6. Download PDF.

Roberts, Adam. 2009. 'Doctrine and Reality in Afghanistan', Survival, Vol. 51, No. 1.

Roberts, Rebecca. 2009. 'Improving Mutual Accountability for Aid Effectiveness' Afghanistan Research and Evaluation Unit. Download PDF.

Roberts, Rebecca. 2009. 'Reflections on the Paris Declaration and Aid Effectiveness in Afghanistan', AREU. Download PDF.

Robichaud, Carl. 2007. 'Buying Time in Afghanistan’, World Policy Journal, Summer.

Robichaud, Carl. 2006. 'Remember Afghanistan? A glass half full, on the Titanic', World Policy Journal, Vol. 23, No. 1. Download PDF.

Robinson, Paul. 2010. 'Soviet hearts and minds operations in Afghanistan', The Historian, Vol. 72, No. 1.

Roi, M. L. and Smolynec, G. 2008. 'End States, Resource Allocation and NATO Strategy in Afghanistan’, Diplomacy \& Statecraft, Vol. 9, No. 2.

Rosenstein, M. et al 2008. 'Can NATO Survive Afghanistan?', Swords and

Ploughshares, Volume XVI, Issue 2. Download PDF.

Rovner, Joshua and Austin Long. 2011. 'Dominoes on the Durand Line? Overcoming Strategic Myths in Afghanistan and Pakistan’, CATO. Download PDF.

Rowe, Chris. 2005. 'Democratization in Afghanistan', in Human Rights and Post-War Reconstruction. Human Rights and Human Welfare. Download PDF.

Roy, Olivier. 2005. 'The predicament of 'civil society' in Central Asia and the 'Greater Middle East’, International Affairs, 81, pp. 1001-1012.

Roy, Olivier. 2004. 'Development and political legitimacy: the cases of Iraq and Afghanistan’, Conflict, Security \& Development, Vol. 4, No. 2, pp. 167-179.

Roy, Olivier. 1990. 'Afghanistan: modèles anthropologiques et pacification', Cahiers du monde russe et soviétique, Vol. 31, 2/3, pp. 405-412. 
Rubin, Barnett R. 2009. 'The Transformation of the Afghan State', in The Future of Afghanistan, edited by J. Alexander Thier. United States Institute of Peace. PDF.

Rubin. Barnett R. 2006. 'Peace Building and State-building in Afghanistan: Constructing Sovereignty for Whose Security?', Third World Quarterly, 27(1): 175-185. (Feb. 2006

Rubin, Barnett R. 2004. '(Re)Building Afghanistan : The Folly of Stateless Democracy', Current History, Vol. 103, No. 672.

Rubin, Barnett R. and Andrea Armstrong. 2002. 'Regional issues in the reconstruction of Afghanistan', World Policy Journal, 20(1), Winter 2002-2003. Download PDF.

Rubin, B. R. and H. Hamidzada. 2007. 'From Bonn to London: Governance Challenges and the Future of Statebuilding in Afghanistan', International Peacekeeping, 14:1.

Rubin, Barnett R., Humayun Hamidzada, and Abby Stoddard. 2005. 'Afghanistan 2005 and beyond: prospects for improved stability reference document', Netherlands Institute of International Relations (April 2005). Download PDF.

Ruiz, Diego. 2007. 'NATO’s Political and Strategic Vision for Afghanistan Palmer', $2^{\text {nd }}$ Annual Baltic Conference on Defence (ABC/D): NATO in Afghanistan. Download PDF.

Ruparelia, Sanjay and Ruth Rennie. 2008. 'Governance and Development in Afghanistan', in State Building, Security, and Social Change in Afghanistan: Reflections on a Survey of the Afghan People. The Asia Foundation. Download PDF.

Rupp, Richard. 2006. 'High Hopes and Limited Prospects: Washington's Security and Nation-Building Aims in Afghanistan', Cambridge Review of International Affairs, Volume 19, Number 2: pages 285-98. (June 2006).

RUSI. 2011. 'Afghanistan in transition: Governance, Counter-Corruption and Development: Reshaping Priorities for 2015 and Beyond', Download PDF.

Ruttig, Thomas. 2008. 'Afghanistan: Institutionen ohne Demokratie’, SWP 17 (June 2008). Download PDF.

Saboory, Mohammad Hamid. 2005. 'The Progress of Constitutionalism in Afghanistan', in The Shari'a in the Constitutions of Afghanistan, Iran and Egypt: Implications for Private Law. Edited by Nadjma Yassari. Tubingen: Mohr Siebeck.

Sadat, Mir H. 2010. 'U.S.-Iran Engagement Through Afghanistan', Middle East Policy, Vol. 17, No.1.

Saikal, Amin. 2009. 'Afghanistan: A State in Crisis', in V. Mauer and M. Dunn Cavelty (eds.), The Routledge Handbook of Security Studies. Routledge. 
Saikal, Amin. 2008. 'Re-building a Strong State Amidst a Strong Society', CAIS Bulletin, Vol. 15, No. 1, pp. 4,6. Download PDF.

Saikal, Amin. 2007. 'The Afghanistan-Pakistan Border and Afghanistan's Long-Term Stability', in Building State and Security in Afghanistan. Edited by Wolfgang Danspeckgruber. Woodrow Wilson School of Public and International Affairs. PDF.

Saikal, Amin. 2006. ‘Securing Afghanistan’s border’, Survival, Vol. 48, No. 1.

Saikal, Amin. 2005. ‘Afghanistan’s Weak State and Strong Society’, in Making States Work: State Failure and the Crisis of Governance, ed. by Simon Chesterman, Michael Ignatieff and Ramesh Thakur (Tokyo, New York, and Paris), pp. 193-209.

Sajjad. Tazreena. 2010. 'Peace at all Costs? Reintegration and Reconciliation in Afghanistan’, AREU. Download PDF.

Sakhi, Farishta. 2009. 'What is Needed to Enhance National Security?', Swedish Committee for Afghanistan Conference: Peace Building in Afghanistan. Download PDF.

Salonius-Pasternak, Charly. 2011 'Finland's ISAF experience: Rewarding, Challenging and on the Edges of the Politically Feasible', in Statebuilding in Afghanistan:

Multinational Contributions to Reconstruction. Edited by Nik Hynek and Péter Marton. Routledge.

Saltmarshe, Douglas and Abhilash Medhi. 2011. 'Local Governance in Afghanistan: A View from the Ground', AREU. Download PDF.

Santos, Charles and Elizabeth Cabot, and Paul Behrends. 2003. 'The Unfinished War in Afghanistan: National Governance Dilemma and Geopolitical Imperatives’, An occasional paper of the Foundation for Central Asian Development, April 2003.

Schadl, Marcus. 2007. 'The Man Outside: The Problem with the External Perception of Afghanistan in Historical Sources', Asien, 104 (July 2007), pp. 88-105. Download PDF.

Schetter, Conrad und Susanne Schmeidl. 2004. 'Afghanistan: Aktuelle Situation und Möglichkeiten der Befriedung’, pp.503-522 in Erich Reiter (ed.) Jahrbuch für Internationale Sicherheitspolitik 2004. Hamburg: Mitller\&Sohn. Download PDF.

Schetter, Conrad. 2006. 'The Dilemma of Reconstruction in Afghanistan: International Intervention between the State, Civil Society and Traditional Elites' pp. 9-24 in Publication Series on Promoting Democracy under Conditions of State Fragility; Issue 1: Afghanistan. Heinrich Boll Foundation. Download PDF.

Schetter, Conrad. 2006. 'The Dilemma of Reconstruction in Afghanistan: International Intervention between the State, Civil Society and Traditional Elites', Publication series 
on Promoting Democracy in Fragile States under Conditions of State Fragility, Issue 1: Afghanistan. Heinrich Böll Foundation. Download PDF.

Schetter, Conrad. 2002. 'The 'Bazaar Economy’ of Afghanistan: A Comprehensive Approach’, in Christine Noelle-Karimi, Conrad Schetter and Reinhard Schlagenweit (editors) Afghanistan - A Country without a State? Frankfurt am Main, Germany: IKOVerlag fur Interkulturelle Kommunikation.

Schiewek, Eckart. 2007. 'Keeping the Peace without Peacekeepers', in Building State and Security in Afghanistan. Edited by Wolfgang Danspeckgruber. Woodrow Wilson School of Public and International Affairs. Download PDF.

Schlagintweit, Reinhard. 2009. 'Scheitert Afghanistan erneut? (Fazit eines der besten Landeskenner Afghanistan aus jahrzehntelanger persönlicher Erfahrung.). PDF.

Schlagintweit, Reinhard. 2002. 'Afghanistan's road to failure', in Christine NoelleKarimi, Conrad Schetter and Reinhard Schlagenweit (editors) Afghanistan - A Country without a State? Frankfurt am Main, Germany: IKO.

Schmeidl, Susanne and Masood Karokhail. 2009. 'The Role of Non-State Actors in 'Community-based Policing': An Exploration of the Arbakai (Tribal Police) in SouthEastern Afghanistan', Contemporary Security Policy, Vol. 30, No. 2.

Schmeidl, Susanne (with Masood Karokhail), 2009. “'Prêt-a-Porter States': How the McDonalidization of State-Building misses the Mark in Afghanistan', in Martina Fischer and Beatrix Schmelzle (eds.) Building Peace in the Absence of States: Challenging the Discourse on State Failure. Berlin: Berghof Research Center. Download PDF.

Schmeidl, Susanne. 2007. 'Civil Society and State-Building in Afghanistan', in Building State and Security in Afghanistan. Edited by Wolfgang Danspeckgruber. Woodrow Wilson School of Public and International Affairs. Download PDF.

Schmeidl, Susanne. 2007. 'The Emperor's New Cloth: The Unravelling of Peacebuilding in Afghanistan', Friedens-Warte - Journal of International Peace and Organizations, 1-2.

Schmeidl, Susanne, 2005. 'Das Afghan Civil Society Forum als Beitrag zur zivilen Friedensförderung in Afghanistan’, in L. Goetschel und A. Schnabel (eds.) Stärkung der Zivilgesellschaft als Mittel der Friedensförderung? Erfahrungen des Afghan Civil Society Forum (ACSF), Conference Paper der swisspeace Jahreskonferenz 2004. Download PDF.

Schneiderhan, Wolfgang. 2007. 'Alliance’s Political and Security Challenges in Afghanistan: What Can Member States Commonly and Germany Individually Do?', $2^{\text {nd }}$ Annual Baltic Conference on Defence. Download PDF.

Schutte, S. 2009. 'Informal (In)security in Urban Afghanistan’, Iranian Studies, 42(3). 
Schutte, Stefan and Branday Bauer. 2007. 'Legalise informal settlements to give poor families the right to demand basic services', AREU. Download PDF.

Schwartze, Moshe. 2009. 'Department of Defense Contractors in Iraq and Afghanistan: Background and Analysis’, CRS Report for Congress. Download PDF.

Sedra, Mark. 2004. 'Afghanistan: Democracy Before Peace?', FPIF Special Report, (September 2004). Download PDF.

Shah, Sayed Muhammad. 2010. 'Is Capacity Being Built? A Study of Policymaking Process in the Primary and Secondary Education Subsector’, AREU. Download PDF.

Shah, Sayed Mohammad. 2009. 'Afghanistan National Development Strategy (ANDS) Formulation Process: Influencing Factors and Challenges’, AREU. Download PDF.

Shah, Usman. 2006. 'Livelihoods in the Asqalan and Sufi-Qarayateem Canal Irrigation Systems in the Kunduz River Basin’, Amu Darya Series Paper No 4. Download PDF.

Shahid, Shiza. 2009. 'Engaging Regional Players in Afghanistan: Threats and Opportunities’, Center for Strategic and International Studies. Download PDF.

Shahrani, M. Nazif. 2009. 'Afghanistan’s Alternatives for Peace, Governance and Development: Transforming Subjects to Citizens \& Rulers to Civil Servants', The Afghanistan Papers, No. 2. The Centre for International Governance Innovation. PDF.

Shahrani, M. Nazif. 2005. 'King Aman-Allah of Afghanistan's failed nation-building project and its aftermath (review article)', Iranian Studies, 38:4.

Shahrani, M. Nazif. 2001. 'Not “Who?” but “How?”: Governing Afghanistan after the conflict', Federations (October 2001).

Shahrani, M. Nazif. 1998. 'Make Afghanistan Part of the "Silk Road Strategy Act of 1997”', Silk Road: A Journal of West Asian Studies, 1(5): pp. 18-21.

Shannon, Róisín. 2009. 'Playing with principles in an era of securitized aid', Progress in Development Studies, Vol. 9, No. 1.

Sharan, Timor. N.d. 'The Dynamics of Elite Networks and Patron-Client Relations in Post-Bonn Statebuilding Afghanistan.’ Download PDF.

Sharan, Timor. 2010. 'International Peacebuilding: An Analysis of Peacemaking in Afghanistan’, Atlantic Community. Download PDF.

Sharma, Prakhar. 2010. 'Local Contours of Security in Afghanistan’, Stimson. PDF. 
Sharma, Raghav. 2008. ‘Afghan Cauldron: Achieving India's Interests', IPCS Issue Briefs, Issue 82. Download PDF.

Sharma, Sudhindra and Pawan Kumar Sen. 2008. 'Institutionalization of the Justice System', in State Building, Security, and Social Change in Afghanistan: Reflections on a Survey of the Afghan People. The Asia Foundation. Download PDF.

Shroder, John. 2007. 'Afghanistan’s Development and Functionality: Renewing a Collapsed State’,GeoJournal, Vol. 70: pp. 91-107.

Siegel, Scott. 2010. 'Learning by Not Doing: Comparative European Experiences in Afghanistan’, Western Political Science Association 2010 Annual Meeting. Link.

SIGAR. 2011. 'April 30, 2011 Quarterly Report to Congress', Special Inspector General for Afghanistan Reconstruction. Download PDF.

SIGAR. 2010. 'Actions Needed to Improve the Reliability of Afghan Security Force Assessments’, Special Inspector General for Afghanistan Reconstruction. PDF.

SIGAR. 2009. 'Special Inspector General For Afghanistan Reconstruction -- Quarterly Report to the United States Congress, October 2009’, Special Inspector General for Afghanistan Reconstruction. Download PDF.

SIGAR. 2009. 'Strategy and Resources Needed to Sustain Afghan Electoral Capacity', Source : Office of Special Inspector General for Afghanistan Reconstruction. PDF.

SIGAR. 2009. Contract Oversight Capabilities of the Defense Department's Combined Security Transition Command - Afghanistan (CSTC-A) Needs Strengthening', Special Inspector General of Afghanistan Reconstruction. Download PDF.

Silinsky, Mark. 2010. 'An Irony of War: Human Development as Warfare in Afghanistan’, Colloquium, Vol. 3, No. 3. Download PDF.

Smethurst, Mark. 2010. 'Creating Conditions for the Defeat of the Afghan Taliban: A Strategic Assessment', Centre for Defence and Strategic Studies, Australian Defence College. Download PDF.

Spanta, Rangin Dadfar. 2005. 'Afghanistan: Nation-Building in the Shadow of the Warlords and the 'War on Terror'' in Nation-building: A Key Concept for Peaceful Conflict Transformation? Jochen Hippler (editor). London: Pluto Press.

Spencer, B. and A. Geller. 2009. 'Mobilizing Traditional Afghan Skills and Perceptions to Increase Rural Development and Security’, Turkish Policy Quarterly, Summer. PDF.

Sperling, James and Mark Webber. 2009. 'NATO: From Kosovo to Kabul’, Chatham House. Download PDF. 
Stahel, Albert A. 2007. 'Since when has Afghanistan been a "Failed State"?', Politorbis, Vol. 42. Download PDF.

Stanekzai, Mohammad M. 2008. 'Thwarting Afghanistan's Insurgency: A Pragmatic Approach toward Peace and Reconciliation’, USIP Special Reports, Issue: 212. PDF.

Stanfield, J. David. 2007. 'Villages and Gozars’, Terra Institute. Download PDF.

Stavridis, James G. 2011. 'The Comprehensive Approach in Afghanistan’, PRISM 2, No. 2. Download PDF.

Stockton, Nicholas. 2002. 'Strategic Coordination in Afghanistan’, AREU. PDF.

Stoddard, Abby et al. 2009. 'Providing Aid in Insecure Environments: 2009 Update Trends in Violence Against Aid Workers and the Operational Response', Overseas Development Institute / Humanitarian Policy Group. Download PDF.

Strand, Arne. 2010. 'When breaking up is hard to do: Exploring exit strategies in Afghanistan', CMI. Download PDF.

Strand, Arne. 2009. 'Faryab Survey: Comparison of Findings from Maymane, 2006 and 2009’, CMI Report. Download PDF.

Suhrke, Astri, et al. 2009. 'Conciliatory Approaches to the Insurgency in Afghanistan: An Overview’, CMI Report. Download PDF.

Suhrke, Astri. 2009. 'The Dangers of a Tight Embrace: Externally Assisted Statebuilding in Afghanistan', in Roland Paris and Timothy D. Sisk (Eds.): The Dilemmas of Statebuilding. Confronting the Contradictions of Postwar Peace Operations. Routledge.

Suhrke, Astri. 2008. 'A Contradictory Mission? NATO from Stabilization to Combat in Afghanistan’, International Peacekeeping, 15(2), pp. 214-236.

Suhrke, Astri. 2007. 'Reconstruction as Modernisation: The 'Post-Conflict' project in Afghanistan’, Third World Quarterly, No. 7, 2007: pp. 1291-1308.

Suhrke, Astri. 2007. 'Democratization of a Dependent State: The Case of Afghanistan', CMI Working Paper 2007: 10. Download PDF.

Suhrke, Astri and Kaja Borchgrevink. 2009. 'Negotiating justice sector reform in Afghanistan’, Crime, Law and Social Change, Vol. 51, No. 2. Download PDF.

Suhrke, Astri et al. 2008. 'Applied Social Science Research in Afghanistan. An Overview of the Institutional Landscape’, CMI Report. Download PDF. 
Suhrke, Astre, Kristian Berg Harpviken, and Arne Strand. 2002. 'After Bonn: conflictual peace building’ Third World Quarterly, Vol. 23, No. 5, pp. 875-891.

Swanstrom, Nilas L. P. and Svante E. Cornell. 2005 'A strategic conflict analysis of Afghanistan’, Central Asia-Caucasus Institute (August 20, 2005). Download PDF.

Szlajfer, Henryk, et al. 2010. 'Future Scenarios for the Conflict in Afghanistan: A Regional Perspective’, Centre for International Relations. Download PDF.

Tadjbakhsh, Shahrbanou. 2011. ‘The Robust India-Pakistan Rivalry’, PRIO. PDF.

Tadjbakhsh, Shahrbanou. 2009. 'Conflicted Outcomes and Values: (Neo)Liberal Peace in Central Asia and Afghanistan’, International Peacekeeping 16(5): 635-651.

Tadjbakhsh, Shahrbanou. 2009. 'Liberal Peace Building and the Challenges to Enhance State Legitimacy', Swedish Committee for Afghanistan Conference: Peace Building in Afghanistan. Download PDF.

Tadjbakhsh, Shahrbanou. 2008. 'International Peacemaking in Tajikistan and Afghanistan Compared: Lessons Learned and Unlearned’, CERIN, No. 143. PDF.

Tadjbakhsh, S. and M. Schoiswohl. 2008. 'The International Community's Democratization Experiment in Afghanistan', International Peacekeeping, Vol. 15(2).

Tariq, Mohammad Osman. 2009. 'Community-based Security and Justice: Arbakai in Afghanistan’, IDS Bulletin, Vol. 40, No. 2.

Tarnoff, Curt. 2009. ‘Afghanistan: U.S. Foreign Assistance’, CRS Report for Congress. Download PDF.

Tarzi, Amin. 2009. 'The Politics of Mass Media', in The Future of Afghanistan, edited by J. Alexander Thier. United States Institute of Peace. Download PDF.

Theros, Marika and Iavor Rangelov. 2010. 'Field Notes from Afghanistan: Perceptions of Insecurity and Conflict Dynamics’, London School of Economics. Download PDF.

Thibault, Michael J. et al. 2009. 'At What Cost? Contingency Contracting in Iraq and Afghanistan', Interim Report to Congress, Commission on Wartime Contracting in Iraq and Afghanistan. Download PDF.

Thier, J. Alexander. 2010. ‘Afghanistan’s Rocky Road to Peace’, Current History (April).

Thier, J Alexander. 2009. 'A Third Branch?: (Re)establishing the Judicial System in Afghanistan', in Building State and Security in Afghanistan. Edited by Wolfgang Danspeckgruber. Woodrow Wilson School of Public and International Affairs. PDF. 
Thier, J Alexander. 2009. 'Introduction: Building Bridges' in The Future of Afghanistan, edited by J. Alexander Thier. United States Institute of Peace. Download PDF.

3D Security. 2009. 'Civil Society Perspectives on US Policy in Afghanistan', 3D Security // Development Diplomacy Defense. Download PDF.

Thruelsen, Peter Dahl. 2007. 'NATO in Afghanistan - What lessons are we learning, and are we willing to adjust?', DIIS REPORT, Vol. 14. Download PDF.

Tierney, John F. 2010. 'Warlord, Inc.: Extortion and Corruption Along the U.S. Supply Chain in Afghanistan’, U.S. House of Representatives. Download PDF.

TLO. 2009. 'Tribal Jurisdiction and Agreements The Key to Sub-National Governance in Southeastern Afghanistan’, Tribal Liaison Office Policy Brief. PDF.

TLO. 2009. 'Linkages between state and non-state justice systems in Eastern Afghanistan evidence from Jalalabad, Nangarhar and Ahmad Aba, Paktia’, Tribal Liaison Office. Download PDF.

TLO. 2009. 'Between the Jirga and the Judge: Alternative Dispute Resolution in Southeastern Afghanistan’, TLO Program Brief/1. Download PDF.

Tondini, Matteo. 2009. 'Justice Sector Reform in Afghanistan: From a 'Lead Nation’ Approach to a ‘Mixed Ownership’ Regime?’, Transit Stud Rev, 15: 660-673.

Tondini, Matteo. 2008. 'From Neo-Colonialism to a 'Light-Footprint Approach': Restoring Justice Systems’, International Peacekeeping, 15:2, pp. 237-251.

Tondini, Matteo. 2007. 'Rebuilding the System of Justice in Afghanistan: A Preliminary Assessment', Journal of Intervention and Statebuilding, Vol. 1, Issue 3, pp. 333-354. Tondini, Matteo. 2006. 'The role of Italy in rebuilding the judicial system in Afghanistan', The Military Law and the Law of War Review, Volumes 1-2. PDF.

Torfeh, Massoumeh and Annabelle Sreberny. 2010. 'Broadcasting to Afghanistan: A history of the BBC Pashto Service' Middle East Journal of Culture and Communication, Volume 3, Number 2.

Torjesen, Stina and Tatjana Stankovic. 2010. 'Regional Change: How will the rise of India and China shape Afghanistan’s stabilization process?’, NUPI. Download PDF.

Townsend, Jacob. 2008. 'Charting a Course for Afghanistan', Australian Strategic Policies Insitute (31 January 2008). Access PDF online.

Trani, Jean F. et al. 2009. 'Lack of a Will or of a Way? Taking a Capability Approach for Analysing Disability Policy Shortcomings and Ensuring Programme Impact in Afghanistan', European Journal of Development Research, Vol. 21. 
Trenin, Dmitri and Alexei Malashenko. 2010. ‘Afghanistan: A View From Moscow’, Carnegie Endowment for International Peace. Download PDF.

Uesugi, Yuji (editor). 2009. Toward Bringing Stability in Afghanistan: A Review of the Peacebuilding Strategy. IPSHU English Research Report Series No.24. PDF.

UK Government. 2009. ‘Global Security: Afghanistan and Pakistan’, United Kingdom House of Commons Foreign Affairs Committee. Download PDF.

Ulriksen, Ståle. 2010. 'Norway's political test in Faryab, Afghanistan: how to lead?', NOREF. Download PDF.

Ulriksen, Ståle. 2010. 'Norway's strategic challenges in Afghanistan: how to make a difference?’, NOREF. Download PDF.

UNAMA. 2007. 'Suicide Attacks in Afghanistan (2001-2007)', United Nations Assistance Mission in Afghanistan. Download PDF.

UN. 2011. 'The situation in Afghanistan and its implications for international peace and security', Report of the Secretary-General. Download PDF.

UN. 2010. 'The Situation in Afghanistan and Its Implications for International Peace and Security: Report of the Secretary General', UN Security Council. Download PDF.

UN. 2009. 'United Nations General Assembly Report of the Secretary General on the Situation in Afghanistan and its Implications for International Peace and Security', United Nations General Assembly / United Nations Security Council. PDF.

UN. 2006. 'Islamic Republic of Afghanistan: publics administration country profile', UN Department of Economic and Social Affairs (January 2006). Download PDF.

UN Secretary-General. 2010. 'The situation in Afghanistan and its implications for international peace and security’, United Nations. Download PDF.

UN Department of Safety and Security. 2007. 'Afghanistan Topic Assessment: Half-Year Review of the Security Situation in Afghanistan', UNDSS. Download PDF.

UNODC. 2010. 'Corruption in Afghanistan: Bribery as reported by the victims.’ PDF.

USAID. 2005. 'Afghanistan Rule of Law Project: Field Study of Informal and Customary Justice in Afghanistan and Recommendations on improving Access to Justice and Relations Between Formal Courts and Informal Bodies’, USAID. Download PDF.

US Commercial Service. 2005. 'Doing business in Afghanistan: a country commercial guide for US companies’, US Commercial Service (February 6, 2006). Download PDF. 
US Department of Defense. 2010. 'Report on Progress Toward Security and Stability in Afghanistan [November 2010].’ Download PDF.

US Government. 2008. 'United States Plan for Sustaining the Afghanistan National Security Forces, June 2008 Report to Congress.’ Download PDF. US Government. 2008. 'Report on Progress toward Security and Stability in Afghanistan', US Congress. Download PDF.

US Senate. 2011. 'Evaluating U.S. Foreign Assistance to Afghanistan.’ PDF.

Vamvakas, Petros. 2011. 'Turkey’s ISAF Mission: A Maverick with Strategic Depth', in Statebuilding in Afghanistan: Multinational Contributions to Reconstruction. Edited by Nik Hynek and Péter Marton. Routledge.

Vamvakas, Petros. 2009. 'NATO and Turkey in Afghanistan and Central Asia: Possibilities and Blind Spots’, Turkish Studies, Vol. 10, No. 1.

van Vleck, Jenifer. 2009. 'An airline at the crossroads of the world: Ariana Afghan Airlines, modernization, and the global Cold War', History and Technology, 25(1).

Vlad, Liviu Bogdan and Adina Negrea. 2009. ‘Afghanistan: Post-Modernizing a PreModern Society?’, Romanian Journal of European Affairs, Vol. 9, No. 3. Download PDF.

Wafaey, Hassan and Anna Larson. 2010. 'The Wolesi Jirga in 2010: Pre-election Politics and the Appearance of Opposition', AREU. Download PDF.

Wagner, Christian. 2010. 'Governance in Afghanistan in Regional Perspective', Afghanistan Analysts Network. Download PDF.

Wahidi, Sayed Maisam. 2011. 'Tackling Corruption and Aid Management in Afghanistan', CAPS. Download PDF.

Wakefield, Shawna, Christina Bennet and Andrew Wilder. 2003. 'Afghan Elections: The Great Gamble’, AREU. Download PDF.

Waldman, Matt and Thomas Ruttig 2011. 'Peace offerings: Theories of conflict resolution and their applicability to Afghanistan’, Afghanistan Analysts Network. Download PDF.

Waldman, Matt. 2010. 'Navigating Negotiations in Afghanistan', USIP Peacebrief, No. 52. Download PDF.

Waldman, Matt. 2010. 'Dangerous Liaisons with the Afghan Taliban: The Feasibility and Risks of Negotiations’, United States Institute of Peace. Download PDF. 
Waldman, Matt. 2010. 'Golden Surrender: The Risks, Challenges, and Implications of Reintegration in Afghanistan’, Afghanistan Analysts Network. Download PDF.

Waldman, M. 'Falling short: aid effectiveness in Afghanistan', ACBAR/Oxfam. PDF.

Waldman, Matt. 2008. 'Community Peacebuilding in Afghanistan: The Case for a National Strategy’, Oxfam International. Download PDF.

Waldman, Matt. 2008. 'Falling Short: Aid Effectiveness in Afghanistan', ACBAR Advocacy Series. Download PDF.

Walker, Elizabeth Lee. 2010. Culturally-Attuned Governance and Justice in Helmand Province, Afghanistan. International Media Ventures/ISAF. Download PDF.

Wardak, A. 2009. 'Rule of Law in Afghanistan: An Overview' in LISD Petersberg Papers on Afghanistan, LCR No IV, Liechtenstein Institute on Self-Determination, Princeton University: New Jersey.

Wardak, A. 2009. 'Rebuilding the Justice System in Afghanistan: Problems and Prospects’, Euro-Atlantic Quarterly, Vol. 16.

Wardak, A. et al 2007. 'Bridging Modernity and Tradition: Rule of Law and the Search for Justice’, Afghanistan Human Development Report. Download PDF.

Wardak, A. 2006. 'Structures of Authority and Local Dispute Settlement in Afghanistan' in Conflicts and Conflict Resolution in Middle Eastern Societies: Between Tradition and Modernity, Edited by Hans-Jörg Albrecht et al, Berlin: Duncker \& Humblot.

Wardak, Ali. 2005. 'Building a post-war Justice System in Afghanistan', in The Shari'a in the Constitutions of Afghanistan, Iran and Egypt: Implications for Private Law. Edited by Nadjma Yassari. Tubingen: Mohr Siebeck.

Wardak, A. 2004. 'The Tribal and Ethnic Composition of Afghan Society' in Afghanistan: Essential Field Guides to Humanitarian and Conflict Zones ( $2^{\text {nd }}$ Edition), edited by Edward Girardet \& Jonathan Walter, Geneva: Crosslines Ltd.

Wardak, Ali. 2004. 'Building a Post-War Justice System in Afghanistan', Journal of Crime, Law and Social Change, Vol. 41: pages 319-341. Download PDF.

Wardak, A. (with Johnson, C. et al) 2003. ‘Afghanistan’s Political and Constitutional Development', Humanitarian Policy Group, Report (January), London: ODI/DFID.

Wardak, A. 2002. 'Jirga: Power and Traditional Conflict Resolution in Afghanistan' in Law After Ground Zero, Edited by John Strawson, London: Cavendish.

Wardak, A. and Gemie, S. 2002. 'Afghanistan after the Taliban, in Planet No: 154. 
Wardak, Mirwais. 2009. 'Regaining People’s Confidence - Strategies to Enhance State Legitimacy and Civil Society', Swedish Committee for Afghanistan Conference: Peace Building in Afghanistan. Download PDF.

Watts, D. 1981. 'Recurrent patterns in traditional Afghan settlements', Afghanistan Journal, Vol. 8, Issue 2, pp. 66-72.

Webber, Mark. 2009. 'NATO: The United States, Transformation and the War in Afghanistan’, British Journal of Politics and International Relations, Vol. 11, pp. 46-63.

Weinbaum, Marvin G. 2007. 'Security in Afghanistan', in Building State and Security in Afghanistan. Edited by Wolfgang Danspeckgruber. Woodrow Wilson School of Public and International Affairs. Download PDF.

Weinbaum, Marvin G. 2006. 'Afghanistan and its neighbors: an ever dangerous neighborhood', United States Institute of Peace. Special Report, no. 162. Download PDF.

Weinbaum, M.G. 1980. 'Legal Elites in Afghan Society', International Journal of Middle East Studies, Vol. 12, No. 1, pp. 39-57.

Westad, Arne. 2009. 'Introduction', in Afghanistan: Now You See Me? IDEAS Strategic Update 001. March 2009. Download PDF.

Whitty, Brendan and Hamish Nixon. 2009. 'The Impact of Counter-Terrorism Objectives on Democratization and Statebuilding in Afghanistan', Taiwan Journal of Democracy, Vol. 5, No.1. Download PDF.

Wiebe, D. 1981. 'Verkehrsausbau und Wirtschaftsentwicklung in Afghanistan', Afghanistan Journal, Vol. 8, Issue 2.

Wiebe, D. 1979. 'Charikar. Entwicklungsprobleme eines großstadtnahen Regionszentrums in Afghanistan’, Afghanistan Journal, Vol. 6, Issue 2.

Wiebe, D. 1976. 'Die räumliche Gestalt der Altstadt von Kandahar. Ein kulturgeographischer Beitrag zum Problem der partiellen Modernisierung', Afghanistan Journal, Vol. 3, Issue 4.

Wiebe, D. 1975. 'Zum Problem stadtplanerischer Entscheidungsprozesse in Afghanistan', Afghanistan Journal, Vol. 2, Issue 4, pp. 135-147.

Wilde, Andreas. 2009. 'Continuity and Hiatus: Structural Patterns of Iran’s Policy in Afghanistan’, Internationales Asienforum, Vol. 40, No. 1-2. Download PDF.

Wilde, Andreas. 2007. Imaginations of a Country: Spatial Perceptions and Mental Mapping in Heart', Asien, 104 (July 2007), pp. 119-134. Download PDF. 
Wilder, Andrew and Sarah Lister. 2007. 'State-Building at the Subnational Level in Afghanistan: A Missed Opportunity’, in Building State and Security in Afghanistan. Edited by W. Danspeckgruber. Woodrow Wilson School. Download PDF.

Wilder, Andrew. 2005. 'A House Divided? Analysing the 2005 Afghan Elections', AREU. Download PDF.

Williams, M.J. 2011. 'Empire Lite Revisited: NATO, the Comprehensive Approach and State-building in Afghanistan’, International Peacekeeping, Vol. 18, Issue 1.

Wilkens, Ann. 2009. 'Relations between Pakistan and Afghanistan', in Kristina Zetterlund (ed.), Pakistan - Consequences of Deteriorating Security in Afghanistan. Stockholm: FOI (Swedish Defence Research Agency). Download PDF.

Williams-Bridgers, Jacquelyn et al. 2009. 'Iraq and Afghanistan: Security, Economic, and Governance Challenges to Rebuilding Efforts Should Be Addressed in U.S. Strategies', Government Accountability Office. Download PDF.

Wilson, Isaiah. 2010. 'America's Intervention in Afghanistan: A Deconstruction’, APSA 2010 Annual Meeting Paper. Link to PDF.

Wilton Park Conference. 2010. 'Winning 'hearts and minds' in Afghanistan: assessing the effectiveness of development aid in COIN operations' Report on Wilton Park Conference. Download PDF.

Wily, Liz Alden. 2009. 'Recommended strategy for conflict resolution of competing high pasture claims of settled and nomadic communities in Afghanistan', United Nations Environment Programme. Download PDF.

Winter, Elizabeth. 2010. ‘Civil Society Development in Afghanistan’, LSE. PDF.

Witter, David, Anthony Bell, and Michael Whittaker. 2011. 'Reversing the Northeastern Insurgency’, ISW Afghanistan Report No. 9. Download PDF.

World Bank. 2009. 'Fight Corruption in Afghanistan: Summaries of Vulnerabilities to Corruption Assessments.’ Download PDF.

World Bank. 2007. 'Service Delivery and Governance at the Sub-National Level in Afghanistan’,World Bank. Download PDF.

World Bank. 2006. 'The World Bank in Afghanistan', World Bank Country Update (January 2006). Download PDF.

Yasushi, Katsuma. 2004. 'Humanitarian Asistance in Afghanistan before September 11: Its Coverage and Relevance’, JCAS Symposium Series, 21. 
Young, Dennis O. 2007. 'Overcoming the Obstacles to Establishing a Democratic State in Afghanistan’, Strategic Studies Institute. Download PDF.

Yousafzai, Rahim Ullah. 2011. 'Pakistan-Afghanistan Relations: A Pakistani Narrative', Pakistan Institute of Legislative Development and Transparency. PDF.

Yusuf, Moeed W. 2010. 'The U.S.-Pakistan Relationship and Finding an End State in Afghanistan', CTC Sentinel, Vol. 3, No. 9. Download PDF.

Zenkevicius, Gintautas. 2007. 'Post-Conflict Reconstruction: Rebuilding Afghanistan - Is That Post-conflict Reconstruction?’, Baltic Security \& Defence Review, Volume 9, 2007.

Ziring, Lawrence. 2009. 'Unraveling the Afghanistan-Pakistan Riddle', Asian Affairs: An American Review, Vol. 36, No. 2.

Zyck, Steven. 2009. 'Former combatant reintegration and fragmentation in contemporary Afghanistan’, Conflict, Security and Development, Vol. 9, No. 1.

Zyla, Ben. 2011. '(Chapter on Canada)', in Statebuilding in Afghanistan: Multinational Contributions to Reconstruction. Edited by Nik Hynek and Péter Marton. Routledge.

\section{Dissertations and Theses}

Burke, Sean M. 2009. 'Rule of law in Afghanistan: time for a new approach?', Thesis. Joint Forces Staff College, Joint Advanced Warfighting School.

van Grieken, D. D. 2005. ‘Collaborating Warlords in Afghanistan’s Political Reconstruction Process’, Utrecht University MA Thesis. Download PDF.

Hartenberger, Lisa Anne (and?) Straubhaar, Joseph D. (2005) Mediating transition in Afghanistan, 2001-2004. Thesis (Ph. D.)--University of Texas at Austin. Download PDF.

Hussain, Khawar. 2005. 'Pakistan’s Afghanistan Policy’, Master’s Thesis, Naval Postgraduate School. Monterey, CA. Download PDF.

Langenkamp, Daniel. 2002. 'The Aims and Impacts of Aid in Afghanistan' MA Thesis, The Fletcher School of Law and Diplomacy. Download PDF.

Löfflmann, Georg. 2007. Verteidigung am Hindukusch? die Zivilmacht Deutschland und der Krieg in Afghanistan. Zugl.: Berlin, Humboldt-Univ., Masterarbeit.

Miraki, Mohammad Daud. 2000. Factors of Underdevelopment in Afghanistan, 19192000. PhD Dissertation. University of Illinois. 
O'Connell, Thomas J. 2008. Afghanistan reconstruction a quantitative analysis of the international effort. Thesis (M.A). Naval Postgraduate School, March 2008.

Ponzio, Richard. 2007. International peacebuilding through democratic legal authority formation: the case of Afghanistan, 2001-2005. Thesis (D.Phil.)--University of Oxford.

Rhinefield, Jeffrey D. 2006. 'Implications of Societal Fragmentation For State Formation: Can Democracy Succeed in Afghanistan?’ Thesis, NPS. Download PDF.

Roe, Andrew M. 2005. British governance of the North-West Frontier (1919 to 1947): a blueprint for contemporary Afghanistan? Thesis (MMAS) CGSC. Download PDF. 


\section{Policy: Announcements, Recommendations and Criticisms}

Adams, Gordon. 2009. 'Afghanistan and Pakistan: The Graveyard for US Foreign Policy Planning?’, Henry L. Stimson Center. Read online.

Adler, Stephanie, et al. 2010. 'Next Steps for the U.S. in Afghanistan', Henry M. Jackson School of International Studies, Task Force 2010. Download PDF.

Afghanistan Study Group. 2010. 'A new way forward: rethinking U.S. strategy in Afghanistan.’ Download PDF.

Alexander, Christopher. 2010. 'Ending the Agony: Seven Moves to Stabilize Afghanistan’, Centre for International Governance Innovation. Download PDF.

Ali, Tariq. 2008. 'Afghanistan: Mirage of the good war', New Left Review (50), MarchApril. Download PDF.

ARGO. 2009. 'Afghanistan, In the aftermath of the elections', Report No.11. PDF.

ARGO. 2009. 'Afghanistan, A difficult moment for democracy, Report No. 10. PDF.

Armitage, Richard L. and Samuel R. Berger (chairs). 2010. 'U.S. Strategy for Pakistan and Afghanistan', Council on Foreign Relations, Independent Task Force Report No. 65. Download PDF.

Arsala, Khushal and Stephen Zunes, 2009. 'The U.S. and Afghan Tragedy', February 18, 2009. FPIF Special Report. Read online.

Asia Society. 2009. 'Back From the Brink? A Strategy for Stabilizing AfghanistanPakistan’, Asia Society, April 2009. Download PDF.

Atlantic Council. 2008. 'Saving Afghanistan: An Appeal and Plan for Urgent Action', The Atlantic Council of the United States, Issue Brief (January 2008). Download PDF.

Ayub, Fatima, Antonella Deledda and Patricia Gossman. 2009. 'Vetting Lessons for the 2009-10 Elections in Afghanistan’, International Center for Transitional Justice. PDF.

Aziz, Masood. 2009. 'Failure Is Not Realism: It's time to stop making excuses for why Afghanistan can't be won.’ Read online. 
Barfield, Thomas and N. Nojumi. 2010. 'Bringing More Effective Governance to Afghanistan: 10 Pathways to Stability’, Middle East Policy, Vol. XVII, No. 4.

Barno, David W., Andrew M. Exum, and Matthew Irvine. 2011. 'Beyond Afghanistan: A Regional Security Strategy for South and Central Asia’, CNAS. PDF.

Barno, David W. and Andrew M. Exum. 2010. 'Responsible Transition: Securing U.S. Interests in Afghanistan Beyond 2011', CNAS. Download PDF.

Bernard, Cheryl et al (editors). 2007. 'Afghanistan: State and Society, Great Power Politics, and the Way Ahead', RAND. Download PDF.

Boivin, Marc André. 2007. 'The Afghan mission is in Canada’s national interest', Inroads, \#20. Download PDF.

Brahimi, Lakhdar and Thomas R. Pickering. 2001. 'Afghanistan: Negotiating Peace', Century Foundation Report. Download PDF.

Browne, Des and Stephen Carter. 2009. Afghanistan: the change we need', RUSI Journal, Vol. 155, No. 3.

Bubalo, Anthony. 2009. 'Obama’s Surge: The United States, Australia and the Second War for Afghanistan’, Lowy Institute Policy Brief. Download PDF.

Campbell, Jason, Michael O’Hanlon, and Jeremy Shapiro. 2009. 'How to Measure the War', Policy Review (October-November).

Cameron, David. 2001. 'Overview: A role for federalism in Afghanistan after the Taliban’, Federations (October 2001).

Canadian Government. 2009. 'Canada's Engagement in Afghanistan [September]’, PDF.

Canadian Government. 2008. 'How Are We Doing in Afghanistan? Canadians Need to Know', Report of the Standing Senate Committee on National Security and Defence Second Session Thirty-ninth Parliament. Read online.

Canadian Government. 2008. 'Tenth Report of Canada's Mission In Afghanistan: Report of the Special Committee on the Canadian Mission in Afghanistan’, The Standing Committee on Foreign Affairs and International Development / House of Commons. PDF.

Canadian Peace Alliance. 2007. 'Bring the troops home now: Why a military mission will not bring peace to Afghanistan.’ Download PDF.

Cantalapiedra, David García. 2009. ‘Is There a Better Strategy for Afghanistan?’, FRIDE. Download PDF. 
Carter, Stephen and Kate Clark. 2010. 'No Shortcut to Stability: Justice, Politics and Insurgency in Afghanistan’, Chatham House. Download PDF.

CASC. 2010 'Keeping our Promises: Canada in Afghanistan Post-2011:

The Way Forward’, Canada-Afghanistan Solidarity Committee. Download PDF.

Christia, Fotini and Michael Semple. 2009. 'Flipping the Taliban: How to Win in Afghanistan’, Foreign Affairs, Vol. 4, No. 88. July/August 2009.

Cilluffo, Frank J. and Joseph R. Clark. 2009. 'Micro-Diplomacy in Afghanistan:

Disaggregating and Engaging the Taliban’, Homeland Security Policy Institute. PDF.

Coelmont, Jo. 'End-State Afghanistan: A European Perspective’, EGMONT Security Policy Brief \#2. Download PDF.

Cogan, C. 2008. 'Afghanistan: Partners in Time’, World Policy Journal, Vol. 25, No. 3.

Cooper, Laird, Campbell, \& Hoffman. 2008. 'Afghanistan: Ending a Failed Military

Strategy’, Peaceful Tomorrows. Download PDF.

Cordesman, Anthony and David Kasten and Adam Mausner. 2009. 'Winning in Afghanistan: Creating Effective Afghan Security Forces’, CSIS report. PDF.

Cordesman, Anthony H. 2009. 'Resourcing for Defeat: Critical Failures in Planning, Programming, Budgeting and Resourcing the Afghan and Iraq Wars', Center for Strategic and International Studies. Download PDF.

Cordesman, Anthony. 2009. 'Winning In Afghanistan: How the US Will Win Or Lose the War', CSIS. Download PDF.

Cordesman, Anthony. 2009. ‘The Levin "Plan": The Wrong Approach in Afghanistan’, CSIS. Download PDF.

Cordesman, Anthony H. 2009. 'The Afghanistan Campaign: Can We Win?',Center for Strategic and International Studies. Download PDF.

Cordesman, Anthony. 2009. 'The Afghan-Pakistan Conflict: US Strategic Options in Afghanistan', CSIS. Download PDF.

Cordesman, Anthony H. 2008. 'The Ongoing Lessons of Armed Nation Building In Afghanistan and Iraq', CSIS report. Download PDF.

Cordesman, Anthony. 2008. 'Follow the Money: Why the US Is Losing the War in Afghanistan’, CSIS. Download PDF. 
Cordesman, Anthony. 2007. 'Open Letter to the House Committee on Armed Services', CSIS (January 16, 2007). Download PDF.

Cordesman, Anthony H. 2007. 'Armed Nation Building: The Real Challenge in Afghanistan', CSIS. Download PDF.

Cortright, David. 2011. Ending Obama's War: Responsible Military Withdrawal from Afghanistan. Paradigm Publishers.

Crane, Mary. 2009. 'It Becomes a River: Afghanistan at a Crossroads', World Policy Journal, Vol. 26, No. 1.

Davis, Daniel L. 2009. 'Go Big or Go Deep: An Analysis of Strategy Options on Afghanistan’, Independent Report by DIA analyst. Download PDF.

Daxner, Michael. 2009. 'Afghanistan: Graveyard of Good Intent', World Policy Journal, Vol. 26, No. 2.

Dobbins, James. 2007. 'Ending Afghanistan’s Civil War', Testimony presented before the Senate Foreign Relations Committee on March 8, 2007. Download PDF.

Dorronsoro, Gilles. 2011. ‘Afghanistan: The Impossible Transition’, Carnegie. PDF.

Dorronsoro, Gilles. 2010. 'Afghanistan: Searching for Political Agreement', Carnegie Report. Download PDF.

Dorronsoro, Gilles. 2010. ‘Afghanistan at the Breaking Point’, Carnegie Report. PDF.

Dorronsoro, Gilles. 2009. 'Fixing a Failed Strategy in Afghanistan', Carnegie. PDF.

Dorronsoro, Gilles. 2009. 'Running out of Time: Arguments for a New Strategy in Afghanistan’, CIPS Working Paper, July 2009. Download PDF.

Dorronsoro, Gilles. 2009. 'Focus and Exit: An Alternative Strategy for the Afghan War', Carnegie Endowment Policy Brief. Download PDF.

EastWest Institute. 2011. 'Seeking solutions for Afghanistan: Second report on the Abu Dhabi process.’ Download PDF.

Elias, Barbara. 2009. 'Know Thine Enemy: Why the Taliban Cannot Be Flipped', Foreign Affairs, November. Read online.

Evans, Anne et al. 2004. Subnational Administration In Afghanistan: Assessment And Recommendations For Action. World Bank. 
Evans, Jonathan. 2008. 'Why NATO Must Win in Afghanistan: A Central Front in the War on Terrorism', The Heritage Foundation Publication. Download PDF.

Exum, Andrew. 2010. 'Leverage: Designing a Political Campaign for Afghanistan', Center for a New American Security. Download PDF.

Exum, Andrew. 2009. ‘Afghanistan 2011: Three Scenarios’, CNAS Policy Brief. PDF.

Exum, Andrew W. et al. 2009. 'Triage: The Next Twelve Months in Afghanistan and Pakistan’, CNAS Report. Download PDF.

Fair, C. Christine and Seth G Jones. 2009. 'Securing Afghanistan: Getting on Track', USIP Working Paper. Download PDF.

Fontaine, Richard and John Nagl. 2009. 'Afghanistan Strategy on Stage: Five Key Questions for the Administration’, CNAS. Download PDF.

Gant, Jim. 2009. ‘A Strategy for Success in Afghanistan: One Tribe at a Time.’ PDF.

Ghai, Yash. 2003. 'Unitary or Federal: A False Choice? Decentralisation of State Powers in Afghanistan’, An Options Paper for the Afghan Constitutional Commission. PDF.

Ghani, Ashraf. 2009. 'A Ten-Year Framework for Afghanistan: Executing the Obama Plan. . . And Beyond’, Atlantic Council. Download PDF.

Giustozzi, Antonio. 2004. ' 'Good' state versus 'bad' warlords?: a critique of statebuilding strategies in Afghanistan’, Crisis States working paper no. 51. Download PDF.

van de Goor, Luc and Mathijs van Leeuwen. 2000. 'The Netherlands and Afghanistan: Dutch Policies and Interventions with regard to the Civil War in Afghanistan', Clingendael Conflict Research Unit. Download PDF.

Government Accountability Office. 2009. 'Afghanistan Security: U.S. Programs to Further Reform Ministry of Interior and National Police Challenged by Lack of Military Personnel and Afghan Cooperation', U.S. Government Accountability Office. PDF.

Government Accountability Office. 2009 'Contingency Contracting: Further Improvements Needed in Agency Tracking of Contractor Personnel and Contracts in Iraq and Afghanistan', U.S. Government Accountability Office. Download PDF.

Government Accountability Office. 2009. 'Contingency Contracting: DOD, State, and USAID Continue to Face Challenges in Tracking Contractor Personnel and Contracts in Iraq and Afghanistan’, U.S. Government Accountability Office. Download PDF.

Government Accountability Office. 2009. 'Afghanistan and Pakistan: Oversight of U.S. Interagency Efforts’, U.S. Government Accountability Office. Download PDF. 
Government Accountability Office. 2009. 'Military Operations: Actions Needed to Improve Oversight and Interagency Coordination for the Commander's Emergency Response Program in Afghanistan’, U.S. Government Accountability Office. PDF.

Government Accountability Office. 2009. 'Afghanistan: Key Issues for Congressional Oversight’, U.S. Government Accountability Office. Download PDF.

Government Accountability Office. 2009. 'Afghanistan: U.S.- and InternationallyFunded Roads’, U.S. Government Accountability Office. Download PDF.

Government Accountability Office. 2009. 'Contingency Contracting: DOD, State, and USAID Are Taking Actions to Track Contracts and Contractor Personnel in Iraq and Afghanistan', U.S. Government Accountability Office. Download PDF.

Government Accountability Office. 2009. 'Iraq and Afghanistan: Security, Economic, and Governance Challenges to Rebuilding Efforts Should Be Addressed in U.S. Strategies', U.S. Government Accountability Office. Download PDF.

Government Accountability Office. 2009. 'Afghanistan Security: U.S. Programs to Further Reform Ministry of Interior and National Police Challenged by Lack of Military Personnel and Afghan Cooperation', U.S. Government Accountability Office. PDF.

Government Accountability Office. 2009. 'Securing, Stabilizing, and Developing Pakistan's Border Area with Afghanistan: Key Issues for Congressional Oversight’, U.S. Government Accountability Office. Download PDF.

Government Accountability Office. 2009. 'Afghanistan Security: Corrective Actions Are Needed to Address Serious Accountability Concerns about Weapons Provided to Afghan National Security Forces’, U.S. Government Accountability Office. Download PDF.

Government Accountability Office. 2009. 'Iraq and Afghanistan: Availability of Forces, Equipment, and Infrastructure Should Be Considered in Developing U.S. Strategy and Plans’, U.S. Government Accountability Office. Download PDF.

Government Accountability Office. 2009. 'Afghanistan Security: Lack of Systematic Tracking Raises Significant Accountability Concerns about Weapons Provided to Afghan National Security Forces', U.S. Government Accountability Office. Download PDF.

Government Accountability Office. 2008. 'Afghanistan Reconstruction, Progress Made in Constructing Roads, but Assessments for Determining Impact and a Sustainable Maintenance Program Are Needed', US Government Accountability Office. PDF.

Government Accountability Office. 2005. 'Afghanistan reconstruction: despite some progress, deteriorating security and other obstacles continue to threaten achievement of U.S. goals', US Government Accountability Office. Download PDF. 
Government of Canada. 2011. 'Canada's Engagement in Afghanistan: Quarterly Report to Parliament For the Period of January 1 to March 31, 2011.' Download PDF.

Grant, George. 2010. 'Succeeding in Afghanistan', The Henry Jackson Society. PDF.

Gregg, Tom. 2010. 'Is a Regional Pact to Stabilize Afghanistan Possible?', New York University Center on International Cooperation. Download PDF.

Gregg, Tom. 2009. 'Caught in the Crossfire: The Pashtun Tribes of Southeast Afghanistan’, Lowy Institute Policy Brief. Link to PDF.

Hanson, Victor Davis. 2009. 'Phony War: Afghanistan and the Democrats', World Affairs, Vol. 171, No. 3.

von Hippel, Karin. 2008. ‘Confronting Two Key Challenges in Afghanistan’, CSIS. PDF.

ICoS. 2011. 'Afghanistan Transition and Kabul University: Winning Minds, Losing Hearts.’ Download PDF.

ICoS. 2010. ‘Afghanistan: The Relationship Gap.’ Download PDF.

ICoS. 2010. 'Operation Moshtarak: Lessons Learned', The International Council on Security and Development. Download PDF.

ICoS. 2010. 'Afghanistan Transition: Missing Variables', International Council on Security and Development. Download PDF.

ICoS. 2009. 'Political Quagmire in Afghanistan.’ Download PDF.

ICoS. 2009. 'Afghanistan's Presidential Election: Power to the People, or the Powerful?', International Council on Security and Development, March 2009. Download PDF.

ICoS. 2009. 'Afghanistan Elections: Guns and Money', The International Council on Security and Development. Download PDF.

Innocent, Malou and T. G. Carpenter. 2009. 'Escaping the “Graveyard of Empires”: A Strategy to Exit Afghanistan’, CATO Institute. Download PDF.

Integrity Watch Afghanistan. 2008. 'Afghanistan: Bringing Accountability Back In From Subjects of Aid to Citizens of the State’, Integrity Watch Afghanistan. PDF.

International Crisis Group. 2011. ‘Afghanistan’s Elections Stalemate’, International Crisis Group, Asia Briefing No. 117. Download PDF. 
International Crisis Group. 2011. 'The Insurgency in Afghanistan’s Heartland', International Crisis Group, Asia Report No. 207. Download PDF.

International Crisis Group. 2010. 'Afghanistan: Exit vs Engagement', International Crisis Group, Asia Briefing No. 115. Download PDF.

International Crisis Group. 2010. 'A Force in Fragments: Reconstituting the Afghan National Army’, International Crisis Group. Download PDF.

International Crisis Group. 2010. ‘Reforming Afghanistan’s Broken Judiciary’, International Crisis Group, Asia Report No. 195. Download PDF.

International Crisis Group. 2009. 'Afghanistan: Elections and the Crisis of Governance', Asia Briefing. PDF.

International Crisis Group. 2009. 'Afghanistan: New U.S. Administration, New Directions’, International Crisis Group Asia Briefing No. 89. Download PDF.

International Crisis Group. 2009. ‘Afghanistan’s Election Challenges’, Asia Report No. 171. Access PDF online.

International Crisis Group. 2008. 'Taliban Propaganda: Winning the War of Words?', Asia Report No. 158. Download PDF.

International Crisis Group. 2008. 'Afghanistan: The Need for International Resolve', Asia Report No. 145 (6 February 2008). Download PDF.

International Crisis Group. 2006. 'Countering Afghanistan’s Insurgency: No Quick Fixes’ Asia Report N¹23 (November 2, 2006). Download PDF.

International Crisis Group. 2006. ‘Afghanistan’s new legislature: making democracy work’, Asia Report no. 116 (May 15, 2006). Access PDF online.

International Crisis Group. 2005. 'Rebuilding the Afghan state: the European Union's role’, Asia Report no. 107 (November 30, 2005). Access PDF online.

International Crisis Group. 2005. ‘Afghanistan’s elections: endgame or new beginning?', Asia Report no. 101 (July 21, 2005). Access PDF online.

International Crisis Group. 2005. 'Political parties in Afghanistan', Asia Briefing no. 39 (June 2, 2005). Access PDF online.

International Crisis Group. 2005. 'Afghanistan: getting disarmament back on track', Asia Briefing no. 35, (February 23, 2003). Access PDF online. 
International Crisis Group. 2004. 'Afghanistan: from presidential to parliamentary elections’, Asia Report no. 88 (November 23, 2004). Access PDF online.

International Crisis Group. 2004. “Elections and security in Afghanistan’, Asia Briefing no. 31 (March 30, 2004). Access PDF online.

International Crisis Group. 2003. 'Peacebuilding in Afghanistan', International Crisis Group Asia Report, No. 64 (September 29, 2003). Download PDF.

International Crisis Group. 2003. 'Afghanistan: The Problem of Pashtun Alienation', International Crisis Group Asia Report, No. 62. Download PDF.

International Crisis Group. 2003. 'Afghanistan: the constitutional Loya Jirga', Asia Briefing no. 29 (December 12, 2003). Access PDF online.

International Crisis Group. 2003. 'Disarmament and reintegration in Afghanistan', Asia Report no. 65 (September 30, 2003). Access PDF online.

International Crisis Group. 2003. 'Peacebuilding in Afghanistan', Asia Report no. 64 (September 29, 2003). Acess PDF online.

International Crisis Group. 2003. 'Afghanistan: women and reconstruction', Asia report no. 48 (March 14, 2003). Access PDF online.

Iqbal, Malik Zafar. 2010. 'An Appraisal of the Afghanistan-Pakistan Strategy to Counter Terrorism’, Parameters, Vol. XXXX. Download PDF.

Jalali, Ali A. 2010. ‘Afghanistan in Transition', Parameters, Vol. XXXX. PDF.

Jalali, Ali A. 2009. 'Winning in Afghanistan', Parameters, Spring 2009. Download PDF.

Järvenpää, Minna. 2011. 'Making Peace in Afghanistan: the Missing Political Strategy', USIP. Download PDF.

Jones, James L. et al. 2008. 'Afghanistan Study Group Report: Revitalizing Our Efforts Rethinking Our Strategies', Center for the Study of the Presidency. Download PDF.

Kabul International Conference on Afghanistan. 2010. ‘Communiqué. Download PDF

Kagan, Frederick, et al. 2010. 'Defining Success in Afghanistan', American Enterprise Institute. Download PDF.

Kagan, Frederick W. and Kimberly Kagan. 2009. 'A Comprehensive Strategy for Afghanistan: Afghanistan Force Requirements’, American Enterprise Institute / Institute for the Study of War. Download PDF. 
Kapila, Subhash. 2009. ‘Afghanistan: United States “Af-Pak” Policy Blueprint Strategically Analyzed’, South Asia Analysis Group, Paper no. 3129. Read online.

Kaplan, Eban, and Greg Bruno. 2008. 'The Taliban in Afghanistan’, Council on Foreign Relations. Read online.

Karthikeya, Raja. 2009. 'The Dangers to Afghan Democracy’, openDemocracy. Online.

Karzai, Hekmat and Hyder Akbar. 2009. 'Time to Get Afghanistan Right', Centre for Conflict and Peace Studies. Download PDF.

Kelly, Justin. 2009. 'How to Win in Afghanistan’, Quadrant, Vol. LIII, No. 4.

Kelley, Jim and John Ferris. 2008. 'Should we stay or should we go?', Journal of Military and Strategic Studies, Vol. 10, Issue 2. Download PDF.

Kent, Arthur. 2008. ‘Ottawa Misses Manley’s Best Points’, Policy Options, March. PDF.

Kent, Arthur. 2007. 'Covering up Karzai \& Co.’, Policy Options, July-August. PDF.

Khalilzad, Zalmay, Daniel Byman, Elie D. Krakowski and Don Ritter. 1999.

'Afghanistan White Paper', Afghanistan Foundation. Read Online.

Khosa, Raspal. 2009. 'Finding a way forward in Afghanistan', Australian Strategic Policy Institute. Link to PDF.

Khosa, Raspal. 2008. 'Making it count: Australia's involvement in Afghanistan', Australian Strategic Policy Institute. Link to PDF.

Khosa, Raspal. 2008. 'Coming to terms with the Taliban-dominated insurgency', Australian Strategic Policy Institute. Link to PDF.

Kian, Bijan R. and Wayne Porter. 2010. 'A New Deal: A Plan for Sustainable Afghan Stability’, New America Foundation. Download PDF.

Korb, Lawrence et al. 2009. 'Sustainable Security in Afghanistan: Crafting an Effective and Responsible Strategy for the Forgotten Front', Center for American Progress. PDF.

Korski, Daniel. 2009. 'Shaping Europe’s Afghan Surge’, European Council on Foreign Relations Policy Brief. Download PDF.

Korski, Daniel. 2008. ‘Afghanistan: Europe’s Forgotten War’, European Council on Foreign Relations (January 21, 2008). Download PDF.

Kuchins, Andrew C., et al. 2010. 'Afghanistan: Building the Missing Link in the Modern Silk Road’, The Washington Quarterly, Vol. 33, No. 2. 
Kuchins, Andrew and S. Frederick Starr. 2010. 'The Key to Success in Afghanistan: A Modern Silk Road Strategy’, CSIS. Download PDF.

Kumar, Radha (editor). 2010. ‘Afghanistan-India-Pakistan Trialogue’, Delhi Policy Group. Download PDF.

Lamb, C. and M. Cinnamond. 2009. 'Unity of Effort: Key to Success in Afghanistan', Institute for National Strategic Studies / National Defense University. Download PDF.

Laurenti, Jeffrey. 2011. 'Afghanistan Agonistes: The Many Stakes in a Thirty Years War’, The Century Foundation. Download PDF.

LISD. 2009. 'A "New" Strategy for Afghanistan and Its Region', Liechtenstein Institute on Self-Determination. Download PDF.

Long, Austin. 2010. 'Small is Beautiful: The Counterterrorism Option in Afghanistan', Orbis (spring 2010).

Lopez, Ralph \& Najim Dost. 2009. 'White Paper On Stabilizing Afghanistan through a Cash-for-Work Initiative’, Jobs for Afghans. Download PDF.

Lurås, Helge et al. 2008. 'From Coherent Policy to Coordinated Practice: Are We Delivering Coherently in Afghanistan?’, Norwegian Inst. of Int. Affairs. Download PDF.

MacAllister, Adam E. 2011. 'Unnecessary Evil: The Necessary Exclusion of Gulbuddin Hekmatyar, Small Wars Journal, Vol. 7, No. 1. Download PDF.

Maley, William. 2008. 'NATO and Afghanistan: Made for each other', Foreign Service Journal, Vol. 85, No. 7. Download PDF.

Maley, William and Daoud Yaqub. 2007. 'A Long Hot Summer: Crisis and Opportunity in Afghanistan’, Lowy Institute Policy Brief. Link to PDF.

Manfredi, Federico. 2009. 'Rethinking U.S. Policy in Afghanistan', World Policy Journal, Winter 2008/09, Vol. 25, No. 4, Pages 23-30.

Manley, John et al. 2008. 'Independent Panel on Canada's Future Role in Afghanistan.' Government of Canada. Download PDF.

Markey, Daniel. 2009. 'From AfPak to PakAf: A Response to the New U.S. Strategy for South Asia', Council on Foreign Relations. Download PDF.

Masadykov, Talatbek, Antonio Giustozzi and James M. Page. 2010. 'Negotiating with the Taliban: Toward a solution for the Afghan conflict', Crisis States Working Paper no. 66. Download PDF. 
McArthur, Doug. 2007. 'Don't leave Afghanistan in American hands', Inroads \#20. PDF.

McWilliams, Edmund. 2008. 'Salvaging the Afghanistan venture', Foreign Service Journal, Vol. 85, No. 7. Download PDF.

Miakhel, Shahmahmood. 2010. ‘A Plan to Stabilize Afghanistan’, Centre for International Governance Innovation. Download PDF.

Michailof, Serge. 2008. 'The Seven Capital Sins of the Donor Community in Afghanistan: What went wrong in the security development nexus, and what should be the lessons for U.S. foreign assistance?', German Marshall fund Policy Brief. Download PDF.

Mihalka, Michael. 2008. 'Pashtunistan, NATO and the Global War on Terror', China and Eurasia Forum Quarterly, Volume 6, No. 1. Download PDF.

Millen, Raymond A. 2010. 'Time for a Strategic and Intellectual Pause in Afghanistan', Parameters, Vol. XXXX. Download PDF.

Miller, Paul D. 2011. 'Finish the Job: How the War in Afghanistan Can Be Won', Foreign Affairs, Volume 90, No. 1.

Mukhopadhyay, Alok R. 2009. ‘Evaluating EU’s Role in the Af-Pak Region’, Source : Institute for Defence Studies and Analyses. Read online.

Mullins, Christopher R. 2009. State Capacity and Resistance in Afghanistan. Naval Postgraduate School master's thesis. Download PDF.

Nagl, John A. 2010. ‘A Better War in Afghanistan’, Joint Forces Quarterly, Issue 56. Download PDF.

Nagl, John. 2009. 'A “Better War”: Testimony before the Senate Foreign Relations Committee Wednesday, September 16, 2009.’ CNAS. Download PDF.

Nagl, John A. et al. 2009. 'A Pathway to Success in Afghanistan: The National Solidarity Program’, CNAS policy brief. Download PDF.

Naumann, Craig C. 2009. 'Ten Reasons to Talk to Taliban Hardliners.’ Read online.

Nawa, Fariba. 2006. 'Afghanistan, Inc.: A CorpWatch investigative report', CorpWatch (October 6, 2006). Download PDF.

Neale, Jonathan. 2008. 'Afghanistan: the case against the 'good war', International Socialism 120 (October). Download PDF. 
Neumann, Ronald E. 2009. 'Afghanistan: Thinking Through the Basics', The Stanley Foundation. Download PDF.

Neumann, Ronald E. 2008. 'Implementation: A New Approach to Multinational Coordination in Afghanistan', The Stanley Foundation Policy Analysis Brief. PDF.

Nineham, Chris and Shallice, Jane. 2008. Afghanistan: why we should get out! (intro. John Pilger) Stop The War Coalition (UK), London.

Noetzel, Timo and Thomas Rid. 2009. 'Germany's Options in Afghanistan', Survival, Vol. 51, Issue 5.

NOREF. 2009. 'How can Norway contribute to a long-term regional peace strategy?', January 13 seminar on Afghanistan. Norwegian Peacebuilding Centre. Download PDF.

Novak, Joshua James. 2010. 'Afghanistan Now or Never - Policy Change: Operations in the Post Surge AFPAK Theater.' Download PDF.

O’Hanlon, Michael. 2010. 'Staying Power: The U.S. Mission in Afghanistan Beyond 2011’, Foreign Affairs, Vol. 89, No. 5.

O’Hanlon, Michael and Bruce Riedel. 2010. 'Plan A-Minus for Afghanistan', The Washington Quarterly, Vol. 34, No. 1.

O'Hanlon, Michael. 2009. 'Toward Reconciliation in Afghanistan', The Washington Quarterly, Vol. 32, No. 2.

Orr, Allan. 2009. 'Recasting Afghan strategy', Small Wars \& Insurgencies, Vol. 20(1).

Oxfam et al. 2010. 'Quick Impact, Quick Collapse: The Dangers of Militarized Aid in Afghanistan’, ActionAid; Afghanaid; CARE; Christian Aid; Concern; Norwegian Refugee Council (NRC); Oxfam; Trócaire. Download PDF.

Oxfam. 2010. 'Promises, Promises: A briefing paper for the Kabul Conference on Afghanistan’, Oxfam Briefing Paper. Download PDF.

Oxfam. 2009. 'Memo to President Obama: Ten Point Plan to Change Course in Afghanistan’, Oxfam, January. Download PDF.

Patel, Nirav and David Capezza. 2009. 'From Washington to Kabul to Beijing: Assessing Prospects for U.S.-China-Afghanistan Cooperation’, Small Wars Journal, April. PDF.

Peral, Luis. 2009. 'Afghanistan: Time to Curb the Law of Inertia’, ISS. Download PDF.

Phillips, Andrew. 2009. 'The Anbar Awakening: Can It Be Exported to Afghanistan?', Security Challenges, Volume 5, Number 3. Download PDF. 
Regehr, Ernie. 2007. 'Canada is ignoring its own advice’, Inroads No. 20. PDF.

Robinson, Linda. 2010. 'How Afghanistan Ends: A Political-Military Path to Peace', Small Wars Journal, Vol. 6, No. 12. Download PDF.

Rohr, Karl C. 2010. 'Afghanistan: Security First’, Small Wars Journal, Vol. 6, No. 3. Download PDF.

Rubin, Barnett R., Amin Saikal and Julian Lindley-French. 2009. 'The Way Forward in Afghanistan: Three Views', Survival, Vol. 51, No. 1.

Rubin, Barnett R. and Sara Batmanglich. 2008. 'The U.S. and Iran in Afghanistan: Policy Gone Awry’, MIT CIS Audits of the Conventional Wisdom, Vol. 2008, Issue 15. PDF.

Rubin, Barnett R. and Ahmed Rashid. 2008. 'From Great Game to Great Bargain', Foreign Affairs, Vol. 87, No. 6.

Rubin, Barnett R. 2007. 'Saving Afghanistan’, Foreign Affairs, Vol. 86, Number 1.

Rubin, Barnett R. 2007. 'Salvaging Afghanistan: Testimony before the United States Senate Armed Services Committee’, CIC/NYU. Download PDF.

Rubin, Barnett R. 2006. 'Still ours to lose: Afghanistan on the brink', Written Testimony to U.S. House/Senate. Read online.

Rubin, Barnett R. 2006. 'Afghanistan's uncertain transition from turmoil to normalcy', Council on foreign Relations. Council Special Report, No. 12 (March 2006). PDF.

RUSI. 2008. 'Afghanistan: Preventing an Approaching Crisis’, Royal United Services Institute (RUSI). October.

Samar, Sima. 2009. 'A New Way Forward in Afghanistan: A Request for Change in U.S. Policy’, Center for Human Rights and Humanitarian Law. Download PDF.

Sedra, Mark. 2003. 'Afghanistan: between war and reconstruction: where do we go from here?’, Foreign Policy in Focus, Special Report, March 2003. Download PDF.

SENLIS Afghanistan. 2008. 'Decision Point 2008', SENLIS Council.

Senlis Council. 2006. 'Losing Hearts and Minds in Afghanistan: Canada’s Leadership to Break the Cycle of Violence in Southern Afghanistan'. The Senlis Council.

Shahrani, M. Nazif. 2009. 'Afghanistan’s Alternatives for Peace, Governance and Development: Transforming Subjects to Citizens \& Rulers to Civil Servants', The Centre for International Governance Innovation. Download PDF. 
Shea, Jamie. 2009. 'NATO Strategy - Building the Comprehensive Approach', in Afghanistan: Now You See Me? IDEAS Strategic Update 001. March 2009. PDF.

Shuck, Roger L. 2010. ‘Afghanistan: A War of Necessity?’, US Army War College. Link to PDF.

SIGAR. 2009. 'Quarterly Report to Congress - October', Special Inspector General for Afghanistan Reconstruction. Download PDF.

SIGAR. 2009. 'Quarterly Report to Congress - July’, Special Inspector General for Afghanistan Reconstruction. Download PDF.

SIGAR. 2009. 'Quarterly Report to Congress - April’, Special Inspector General for Afghanistan Reconstruction. Download PDF.

SIGAR. 2009. 'Quarterly Report to Congress - January’, Special Inspector General for Afghanistan Reconstruction. Download PDF.

SIGAR. 2008. 'Quarterly Report to Congress - October', Special Inspector General for Afghanistan Reconstruction. Download PDF.

SIGAR. 2009. 'Strategy and Resources Needed to Sustain Afghan Electoral Capacity', Special Inspector General for Afghanistan Reconstruction. Download PDF.

SIGAR. 2009. 'Increased Visibility, Monitoring, and Planning Needed for Commander's Emergency Response Program in Afghanistan', Special Inspector General for Afghanistan Reconstruction. Download PDF.

SIGAR. 2009. 'A Better Management Information System Is Needed to Promote Information Sharing, Effective Planning and Coordination of Afghanistan Reconstruction Activities’, Special Inspector General for Afghanistan Reconstruction. Download PDF.

SIGAR. 2009. 'UN Action Urged To Strengthen Afghanistan Capacity to Support Future Elections’, Special Inspector General for Afghanistan Reconstruction. Download PDF.

SIGAR. 2009. 'Contract Oversight Capabilities of the Defense Department's Combined Security Transition Command - Afghanistan (CSTC-A) Need Strengthening', Special Inspector General for Afghanistan Reconstruction. Download PDF.

Simon, S. and J. Stevenson. 2009. ‘Afghanistan: How Much is Enough?’, Survival, 51(5).

Small, Andrew. 2009. 'China’s Af-Pak Moment', GMF Policy Brief. Download PDF.

Smith, Ben. 2005. 'Afghanistan: where are we?', Conflict Studies Research Centre, Central Asian Series, June 2005. 
Smith, Gordon. 2007. 'Canada in Afghanistan: Is it Working?' Prepared for the Canadian Defense \& Foreign Affairs Institute. Download PDF.

Stanekzai, Mohammad M. 2008. 'Thwarting Afghanistan's Insurgency: A Pragmatic Approach Toward Peace and Reconciliation', United States Institute of Peace. PDF.

Starr, S. Frederick. 2011. 'Afghanistan Beyond the Fog of Nation Building: Giving Economic Strategy a Chance’, Central Asia-Caucasus Institute \& Silk Road Studies Program. Download PDF.

Starr, S. Frederick. 2003. 'Karzai’s Fiscal Foes and How to Beat Them', in Brief 28, Confronting Afghanistan's Security Dilemma: Reforming the Security Sector, Mark Sedra (ed.). Bonn International Center for Conversion. Download PDF.

Strick van Linschoten, Alex and Felix Kuehn. 2011. 'Separating the Taliban from alQaeda: The Core of Success in Afghanistan', Center on International Cooperation, New York University. Download PDF.

Suhrke, Astri. 2006. 'When More is Less: Aiding Statebuilding in Afghanistan', FRIDE Working Paper \#26. Download PDF.

Taylor, Claire. 2010. 'Afghanistan: Towards a Handover of Security Responsibility?', UK House of Commons Library. Download PDF.

Tellis, Ashley J. 2011. 'Creating New Facts on the Ground', Carnegie Foundation Policy Brief. Download PDF.

Tellis, Ashley J. \& Aroop Mukharji (editors). 2010. Is a Regional Strategy Viable in Afghanistan? Carnegie Foundation. Download PDF.

Tellis, Ashley J. 2009. 'Reconciling With the Taliban? Toward an Alternative Grand Strategy in Afghanistan’, Carnegie Endowment for International Peace. Download PDF.

Theros, Marika and Mary Kaldor. 2011. 'Building Afghan Peace from the Ground Up', Century Foundation Report. Download PDF.

Tremblay, R. 2001. ‘A federal arrangement for Afghanistan’, Federations (October).

Tunç, Hakan. 2007. ‘A stable Afghanistan is within reach’, Inroads No. 20. PDF.

Turse, Nick (editor). 2010. The Case for Withdrawal from Afghanistan. Verso.

UK Government. 2011. 'The UK's foreign policy approach to Afghanistan and Pakistan', Foreign Affairs Committee - Fourth Report. Read online. 
UK Government. 2009. 'UK policy in Afghanistan and Pakistan: the way forward', UK Government April 2009. Download PDF.

US Government. 2009. 'White Paper of the Interagency Policy Group's Report on U.S. Policy toward Afghanistan and Pakistan’, Interagency Policy Group. Download PDF.

Vegetius. 2009. 'Needed: An Exorcism in Kandahar', Small Wars Journal, Dec. PDF.

Viehe, Ariella. 2009. 'Tribal Engagement in Afghanistan: Challenges and Recommendations.’ Download PDF.

deVillafranca, Richard. 2008. 'Reconsidering Afghanistan: Time for an "Azimuth Check”', Parameters, Winter 2008. Download PDF.

Wadhams, Caroline P. and Lawrence J. Korb. 2007. 'The Forgotten Front', The Center for American Progress. Download PDF.

Wimmer, Andreas and Conrad Schetter. 2003. 'Putting State-Formation First: Some Recommendations for Reconstruction and Peace-Making in Afghanistan, Journal of International Development, Vol. 15, pp. 525-539.

Wisner, Frank G. 2009. 'Afghanistan and Pakistan: Mr. Obama's War', American Foreign Policy Interests, Volume 31, Issue 6.

Yaqub, Daoud and William Maley. 2008. 'NATO and Afghanistan: Saving the StateBuilding Enterprise', The Bucharest Conference Papers. German Marshall Fund and Chatham House. Download PDF.

Zakhilwal, Omar. 2001. 'Federalism in Afghanistan: A recipe for disintegration', Federations (October 2001). 


\section{Opium: cultivation, drug use and trafficking}

\section{$\underline{\text { Books }}$}

Chouvy, Pierre-Arnaud. 2010. Opium: Uncovering the Politics of the Poppy. Harvard University Press.

Felbab-Brown, Vanda. 2009. Shooting Up: Counterinsurgency and the War on Drugs. Brookings Institution Press.

Hafvenstein, Joel. 2007. Opium Season: A Year on the Afghan Frontier. The Lyons Press.

Macdonald, David. 2007. Drugs in Afghanistan: Opium, Outlaws and Scorpion Tales. London: Pluto Press.

Paoli, Letizia, Victoria A. Greenfield and Peter Reuter. 2009. The World Heroin Market: Can Supply Be Cut? Oxford University Press.

Peters, Gretchen. 2009. Seeds of Terror: How Heroin Is Bankrolling the Taliban and al Qaeda. Thomas Dunne Books.

Salmon, Gregor. 2009. Poppy: Life Death and Addiction Inside Afghanistan's Opium Trade. Sydney: Random House.

Scott, P.D. 2003. Drugs, Oil, and War: The United States in Afghanistan, Colombia, and Indochina. Lanham, MD: Rowman \& Littlefield.

Singh, Deepali Gaur. 2007. Drugs Production and Trafficking in Afghanistan.

Stienberg, Michael K. Joseph J. Hobbs, and Kent Mathewson, ed. 2004. Dangerous Harvest: Drug Plants and the Transformation of Indigenous Landscapes. New York: Oxford University Press.

\section{$\underline{\text { Reports and articles }}$}

Adelekan M. 2005. 'Paradox in the evaluation of a unique drug control effort in a nonwestern country’, International Journal of Drug Policy, Vol. 16, Number 2. 
Allen, Nigel J. R. 2004. 'Opium Production in Afghanistan and Pakistan', in Dangerous Harvest: Drug Plants and the Transformation of Indigenous Landscapes. Edited by Michael K. Steinberg et al (eds) Oxford University Press.

Anand, Bhuvana. 2004. 'Replacing Narco-Usurers With Micro-Lenders: The Agricultural Finance Component Of Opium Substitution Programs In Afghanistan’, MA Thesis. Tufts University. Download PDF.

Bhattacharji, Romesh and Jorrit E.M. Kamminga. 2010. 'Poppy for Medicine: An Essential Part of a Balanced Economic Development Solution for Afghanistan's Illegal Opium Economy’, Journal of Drug Policy Analysis, Volume 3, Issue 1.

Blanchard, Christopher M. 2009. ‘Afghanistan: Narcotics and U.S. Policy’, Congressional Research Service. Download PDF.

Blanchard, Christopher M. 2007. 'CRS Report for Congress Afghanistan: Narcotics and U.S. Policy’, CRS. Download PDF.

Breckle, S. and M. Koch. 1982. 'Afghanische Drogen und ihre Stammpflanzen. Teil 3: Haschisch und Hanf', Afghanistan Journal, Vol. 9, Issue 4, pp. 115-123.

Breckle, S. 1979. 'Afghanische Drogen und ihre Stammpflanzen. Teil 2: Süßholz’, Afghanistan Journal, Vol. 6, Issue 3, pp. 87-91.

Breckle, S. and W. Unger. 1977. 'Afghanische Drogen und ihre Stammpflanzen. Teil 1: Gummiharze von Umbelliferen’, Afghanistan Journal, Vol. 4, Issue 3, pp. 86-95.

Brown, Allison. 2009. 'Why Buy Something We Hate? Subsidize Other Crops, Not Poppy’, Small Wars Journal, December. Download PDF.

Buddenburg, D. and W. Byrd (eds). 2006. Afghanistan's Drug Industry: Structure, Functioning, Dynamics, and Implications for Counter-narcotics Policy. UNODC/World Bank. Download PDF.

Bureau of International Narcotics and Law Enforcement Affairs. 2008. 'International Narcotics Control Strategy Report - 2008’, US State Department. Read online.

Brown, Allison. 2009. 'Poppy is Not the Most Profitable Crop, It's the Only Crop', Small Wars Journal, June 2009. Download PDF.

Byrd, William and Christopher Ward. 2004. 'Drugs and development in Afghanistan', Conflict Prevention and Reconstruction, Paper no. 18. World Bank. Download PDF.

Byrd, W. 2008. 'Responding to Afghanistan’s Opium Economy Challenge: Lessons and Policy Implications from a Development Perspective’,World Bank. Download PDF. 
Carpenter, Ted Galen. 2004. 'How the drug war in Afghanistan undermines America's war on terror', Foreign Policy Briefing, No. 84 (November 10, 2004). Download PDF.

Caulkins, Jonathan P. et al. 2010. 'Drug production and trafficking, counterdrug policies, and security and governance in Afghanistan’, NYU Center on International Cooperation. Download PDF.

Chouvy, Pierre-Arnaud. 2008. 'Afghanistan and the failure of global counter-narcotics', Afghanistan Info, $n^{\circ}$ 63, September 2008. Read online.

Chouvy, Pierre-Arnaud.2008. 'Licensing Afghanistan's Opium Production: Sollution or Fallacy?’, Caucasian Review of International Affairs, Vol. 2 n², Spring. Read online.

Chouvy, Pierre-Arnaud. 2006. 'Afghanistan’s Opium Production in Perspective', The China and Eurasia Forum Quarterly, Vol. 4, No. 1. Read online.

Chouvy, Pierre-Arnaud. 2004. 'Drugs and the Financing of Terrorism', Terrorism Monitor, Vol. 2, Issue 20, 21 October 2004, pp. 3-5. Read online.

Chouvy, Pierre-Arnaud. 2004. 'Afghan opium predicted to reach new high, Jane’s Intelligence Review, Vol. 16 n 10, October 2004, pp. 29-31. Read online.

Chouvy, Pierre-Arnaud. 2004. 'Narco-Terrorism in Afghanistan', Terrorism Monitor, Vol. 2, Issue 6, 25 March 2004. Read online.

Chouvy, Pierre-Arnaud. 2003. 'Opiate smuggling routes from Afghanistan to Europe and Asia’, Jane’s Intelligence Review, Vol. 15, n 03, mars 2003, pp. 32-35. Read online.

Chouvy, Pierre-Arnaud. 2002, Drug trade in Asia ; Golden Crescent ; Golden Triangle, in Levinson D., Christensen K. (Ed.), 2002, Encyclopedia of Modern Asia, Chicago, Scribners. (Volume 2 : pp.302, 304 ; 441-442 ; 442-443). Read online.

Chouvy, Pierre-Arnaud. 2002, ‘Afghanistan’s opium production rises post-Taliban', Jane’s Intelligence Review, Vol. 14, n 12, pp. 28-29. Read online.

Chouvy, Pierre-Arnaud. 1999. 'Taliban's Drug Dilemma: Opium Production vs. International Recognition', Central Asia - Caucasus Analyst, December . Read online.

Corti, Daniela and Ashok Swain. 2009. 'War on Drugs and War on Terror: Case of Afghanistan', Peace and Conflict Review, Volume 3, Issue 2. Download PDF.

Curry, Peter. 2010. 'Dynamic Tension: Security, Stability, and the Opium Trade', Center for Complex Operations. Download PDF.

DID. 2008. 'Afghanistan: Economic Incentives and Development Initiatives to Reduce Opium Production’, Department for International Development UK / World Bank. PDF. 
Dufour, Charlotte and Domitille Kauffmann. 2010. 'Strategies to counter opiate production in Afghanistan: Are we on the right track?’, URD. Download PDF.

Duncan, Thomas A. 2007. 'Opium: The Fuel of Instability in Afghanistan', SAMS Monograph. Download PDF.

DuPée, Matthew C. 2010. The narcotics Emirate of Afghanistan: armed polities and their roles in illicit drug production and conflict 1980-2010. NPS thesis. PDF.

Durham, Jan R. 2009. 'Opium, Insurgency, and U.S. Counterdrug Strategy in Afghanistan: A Case for Change’, Naval War College Report. Download PDF.

Erwin, Michael. 2009. 'The Insurgent-Narcotic Nexus in Helmand Province', CTC Sentinel, Vol. 2, No. 9. Download PDF.

Farrel, G. and J. Thorne. 2005. 'Evaluation of the Taliban crackdown against opium poppy cultivation in Afghanistan', International Journal of Drug Policy, Vol. 16(2). PDF.

Favre, Raphy. 2005. 'Exploring the Roots of Opium and Illicit Economy in Afghanistan', AIZON publication, Kabul. Download PDF.

Fazey C . 2005. 'Where have all the flowers gone?', International Journal of Drug Policy, Volume 16, Number 2: pages 104-107.

Felbab-Brown, Vanda. 2010. 'The Drug-Conflict Nexus in South Asia: Beyond Taliban Profits and Afghanistan', in The Afghanistan-Pakistan Theater: Militant Islam, Security \& Stability. Edited by Edited by Daveed Gartenstein-Ross \& Clifford D. May. Washington: FDD Press. Download PDF.

Felbab-Brown, Vanda. 2009. 'The 2009 Afghanistan Elections and the Future of Governance', The Brookings Institution. Download PDF.

Felbab-Brown, Vanda. 2009. 'Narco-Belligerents Across the Globe: Lessons from Colombia for Afghanistan?’, The Elcano Royal Institute. Download PDF.

Felbab-Brown, Vanda. 2009. 'Peacekeepers Among Poppies: Afghanistan, Illicit Economies and Intervention', International Peacekeeping, Vol. 16, No. 1.

Felbab-Brown, Vanda. 2009. ‘The Obama Administration’s New Counternarcotics Strategy in Afghanistan: Its Promises and Potential Pitfalls', Brookings Policy Brief Series \#171. Download PDF.

Felbab-Brown, Vanda. 2007. Shooting up: The impact of illicit economies on military conflict. Ph.D dissertation, Massachusetts Institute of Technology. 
Felbab-Brown, Vanda. 2006. 'Kicking the Opium Habit? Afghanistan’s Drug Economy and Politics Since the 1980s', Journal of Conflict, Security, and Development, 6(2).

Felbab-Brown, Vanda. 2005. 'Drugs and State-building in Afghanistan', Precis, Vol. 15, No. 1. Download PDF.

Felbab-Brown, Vanda. 2005. 'Afghanistan: When Counternarcotics Undermines Counterterrorism’, The Washington Quarterly, 28(4). Download PDF.

Gibson, A. et al. 2005. 'Recent Trends in Heroin Supply to Markets in Australia, the United States and Western Europe’, International Journal of Drug Policy, 16(5).

Glaze, John R. 2007. 'Opium and Afghanistan: Reassessing U.S. Counternarcotics Strategy,’ Strategic Studies Institute. Download PDF.

Goodhand, Jonathan. 2009. 'Bandits, Borderlands and Opium Wars: Afghan StateBuilding Viewed from the Margins', DIIS Working Paper 26. Download PDF.

Goodhand, Jonathan. 2008. 'Corrupting or Consolidating the Peace? The Drugs Economy and Post-conflict Peacebuilding in Afghanistan’, International Peacekeeping, 15(3).

Goodhand, Jonathan. 2005. 'Frontiers and Wars: the Opium Economy in Afghanistan', Journal of Agrarian Change, Vol. 5, No. 2.

Goodhand, Jonathan. 2003. 'Frontiers and wars: a study of the opium economy in Afghanistan’, Crisis States (January 2003). Download PDF.

Goodhand, Jonathan. 2000. 'From holy war to opium war? A case study of the opium economy in North Eastern Afghanistan,' Central Asian Survey, 19(2), pp. 265 - 280.

Goodson, Larry 2005. Bullets, Ballots, and Poppies in Afghanistan', Journal of Democracy, Volume 16, Number 1.

Grare, Frédéric. 2008. 'Anatomy of a Fallacy: The Senlis Council and Narcotics in Afghanistan’, CGI Working Paper No. 34.

van Ham, Peter, and Jorrit Kamminga. 2007. 'Poppies for Peace: Reforming Afghanistan's Opium Industry’, Washington Quarterly, Volume 30, Number 1, pp 69-82.

Hayes, Ashton. 2009. 'A Microgrant Supported Poppy Cultivation Renouncement Program for Afghanistan’, US Army War College Strategy Research Project. PDF.

Jelsma M . 2005. 'Learning Lessons from the Taliban Opium Ban', International Journal of Drug Policy, Volume 16, Number 2: pages 98-103. 
Jelsma, M. and T. Kramer. 2005. 'Downward spiral: banning opium in Afghanistan and Burma’, Drugs and Conflict Debate Papers, No. 12, Transnational Institute. PDF.

Koehler, Jan and Zuercher, Christoph. 2007. 'Statebuilding, Conflict and Narcotics in Afghanistan: The View from Below’, International Peacekeeping, 14:1, 62 - 74.

Kreutzmann, Hermann. 2007. 'Afghanistan and the Opium World Market: Poppy Production and Trade’, Iranian Studies, 40(5), pp. 605 - 621.

Kuo, I., S.A. Strathdee. 2005. 'After the Flowers are Gone, What Happens Next?', International Journal of Drug Policy, Volume 16, Number 2: pages 112-114.

Labrousse, A. 2005. 'The Farc and the Taliban's connection to drugs', Journal of Drug Issues, Volume 35, Number 1: pages 169-184.

Lamey, Jay. 2010. 'Declining Opium Poppy Cultivation: Reasons and Effects', AREU. Download PDF.

Łatek, Maciej M. et al. 2010. 'Persistence in the Political Economy of Conflict: The Case of the Afghan Drug Industry’, AAAI Fall Symposium Series. Download PDF.

Lind, Jo Thori, et al. 2009. 'Opium for the Masses? Conflict-Induced Narcotics Production in Afghanistan’, CESifo Working Paper Series No. 2573. Link to PDF.

Lind, Jo Thori. 2009. 'Opium for the Masses? Conflict-induced Narcotics Production in Afghanistan’, University of Oslo, Memorandum No. 5. Download PDF.

Maass, Citha D. 2011. ‘Afghanistan’s Drug Career: from War to Drug Economy’, Afghanistan Analysts Network. Download PDF.

Macdonald, David. 2008. ‘Afghanistan’s Hidden Drug Problem: The Misuse of Psychotropics’, AREU. Download PDF.

Macdonald, D. 2005. 'The Dynamics of Opium Cultivation and Production in Afghanistan under the Taliban', International Journal of Drug Policy, Vol. 16, No. 2.

Maloney, Sean M. 2009. 'On a pale horse? Conceptualizing narcotics production in southern Afghanistan and its relationship to the Narcoterror Nexus', Small Wars \& Insurgencies, Vol. 20, No. 1.

Mankin, Justin. 2009. ‘How Afghan Opium Underpins Local Power', Journal of International Affairs, Vol. 63, No. 1.

Mansfield, D. 2010. 'Where Have all the Flowers Gone? Assessing the Sustainability of Current Reductions in Opium Production in Afghanistan’, AREU. Download PDF. 
Mansfield, David et al. 2008. 'Afghanistan: Economic Incentives and Development Initiatives To Reduce Opium Production’, World Bank. Download PDF.

Mansfield, David and Adam Pain. 2008. 'Counter-Narcotics in Afghanistan: The Failure of Success?', AREU. Download PDF.

Mansfield, David and Adam Pain. 2007. 'Evidence from the Field: Understanding Changing Levels of Opium Poppy Cultivation in Afghanistan’, AREU. Download PDF.

Mansfield, David and Adam Pain. 2006. 'Opium Poppy Eradication: How to raise risk when there is nothing to lose?', AREU. Download PDF.

Mansfield, David. 2009. ““Poppy Free” Provinces: A Measure or a Target?’,Afghanistan Research and Evaluation Unit. Download PDF.

Mansfield, David. 2008. 'Afghanistan: Economic Incentives and Development Initiatives To Reduce Opium Production’, World Bank. Download PDF.

Mansfield, David. 2008. 'Responding to Risk and Uncertainty: Understanding the Nature of Change in the Rural Livelihoods of Opium Poppy Growing Households in the 2007/08 Growing Season’, Afghan Drugs Inter Departmental Unit’, Download PDF.

Mansfield, David. 2008. 'C'Resurgence and Reductions: Explanations for Changing Levels of Opium Poppy Cultivation in Nangarhar and Ghor in 2006-07’, AREU. PDF.

Mansfield, David. 2007. 'Beyond the Metrics: Understanding the Nature of Change in the Rural Livelihoods of Opium Poppy Growing Households in the 2006/07 Growing Season', A Report for the Afghan Drugs Inter Departmental Unit.' Download PDF.

Mansfield, David. 2007. 'Governance, Security and Economic Growth: The Determinants of Opium Poppy Cultivation in the Districts of Jurm and Baharak in Badakhshan', Report fro GTZ/AKDN. Download PDF.

Mansfield, David. 2006. 'Exploring the 'Shades of Grey': An Assessment of the Factors Influencing Decisions to Cultivate Opium Poppy in 2005/06', A Report for the Afghan Drugs Inter Departmental Unit of the U K Government.’ Download PDF.

Mansfield, David. 2006. 'Water Management, Livestock and the Opium Economy: Opium Poppy Cultivation in Nangarhar and Ghor’, AREU. Download PDF.

Mansfield, David. 2006. 'Treating the Opium Problem in World Bank Operations in Afghanistan', World Bank. Download Word doc.

Mansfield, David. 2006. 'Anti-Narcotics Mainstreaming in ADB's Activities in Afghanistan, 2002-2006’, Asian Development Bank. Download Word doc. 
Mansfield, David. 2006. 'Development in a Drugs Environment: A Strategic Approach to Alternative Development’, Discussion Paper GTZ/EOD. Download PDF.

Mansfield, David. 2006. 'Development in a Drugs Environment: A Strategic Approach to Alternative Development', Discussion Paper, GTZ/ EOD. Download PDF.

Mansfield, David. 2005. 'Pariah of Poverty? The opium ban in the province of Nangarhar in the 2004/05 growing season and its impact on rural livelihood strategies', A Report for the Project for Alternative Livelihoods (PAL) in Eastern Afghanistan. Download PDF.

Mansfield, David. 2005. 'Responding To The Challenge Of Diversity In Opium Poppy Cultivation In Afghanistan’, World Bank. Download PDF.

Mansfield, David. 2005. 'What is Driving Opium Poppy Cultivation? The Pressures to Reduce Opium Poppy Cultivation in Afghanistan in the 2004/05 Growing Season’, A Report for the Afghan Drugs Inter Departmental Unit of the UK Government. Word doc.

Mansfield, David. 2004. 'The Role Of Opium As A Source Of Informal Credit In Rural Afghanistan’, World Bank. Word doc.

Mansfield, David. 2004. 'Coping Strategies, Accumulated Wealth and Shifting Markets: The Story of Opium Poppy Cultivation in Badakhshan 2000-2003’ by David Mansfield. A Report for the Agha Khan Development Network. Download Word doc.

Mansfield, David. 2004. 'Diversity and Dilemma: Understanding Rural Livelihoods and Addressing the Causes of Opium Poppy Cultivation in Nangarhar and Laghman, Eastern Afghanistan', Project for Alternative Livelihoods in Eastern Afghanistan. Word doc.

Mansfield, David. 2003. 'Strategic Study \#9: Final Report, February 2003. Opium Poppy Cultivation in a Changing Policy Environment: Farmers' Intentions for the 2002/03 Growing Season', UNODC. Download Word doc.

Mansfield, David. 2003. 'Strategic Study \#9: Final Report, February 2003. Opium Poppy Cultivation in a Changing Policy Environment: Farmers' Intentions for the 2002/03 Growing Season', UNODC. Download Word doc.

Mansfield, David. 2001. 'The Displacement of Opium Poppy Cultivation: A Shift in the Regional Threat?', A Report for the Drugs \& International Crime Department of the Foreign \& Commonwealth Office. Download Word doc.

Mansfield, David. 2001. 'The Economic Superiority of Illicit Drug Production: Myth and Reality. Opium Poppy Cultivation in Afghanistan', a paper prepared for the International Conference in drug control and cooperation, Feldafang, January. Download Word doc.

Mansfield, David. 2001. 'Alternative Development in Afghanistan: The Failure of Quid Pro Quo’, International Conference in drug control and cooperation. Download Word doc. 
Mansfield, David. 2001. 'The Impact of the Taliban Prohibition on Opium Poppy Cultivation in Afghanistan.’, UNODC. Download Word doc.

Mansfield, David. 1999. 'Strategic Study \#3: Preliminary Report, January 1999. The Role of Opium as a source of Informal Credit’, UNODC. Download Word doc.

Mansfield, David. 1999. 'Strategic Study \#4: Final Report, June 1999. Access to Labour: The Role of Opium in the Livelihood Strategies of Itinerant Harvesters Working in Helmand Province, Afghanistan', UNODC. Download Word doc.

Mansfield, David. 1998. 'Strategic Study \#1: Preliminary Report, June 1998. An Analysis of the Process of Expansion of Opium Poppy Cultivation to New Districts in Afghanistan.', UNODC. Download Word doc.

Mansfield, David. 1998. 'Strategic Study \#2: The Dynamics of the Farmgate Opium Trade and the Coping Strategies of Opium Traders’, UNODC. Download Word doc.

Mansfield, David. (n.d.) 'Alternative Development: The Modern Thrust of Supply Side Policy’, United Nations Bulletin on Narcotics, Vol LI, Nos. 1\&2. Download Word doc.

Matthews, Robert. 2008. 'Poppy seeds and dragon's teeth: NATO struggles with an opium-funded war in Afghanistan', FRIDE, Comment (January 2008). Download PDF.

Merz, Andrew A. 2008. Coercion, Cash-Crops and Culture: From Insurgency to ProtoState in Asia’s Opium Belt. Master's Thesis, Naval Postgraduate School. Download PDF.

Nathan, James A. 2009. 'Poppy Blues: The Collapse of Poppy Eradication and the Road Ahead in Afghanistan’, Defense \& Security Analysis, Vol. 25, No. 4.

Pagel, Paul S. 2009. 'The Poppies of Afghanistan’, Anesthesia and Analgesia, Vol. 109.

Pain, Adam. 2008. “"Let Them Eat Promises”: Closing the Opium Poppy Fields in Balkh and its Consequences', AREU. Download PDF.

Pain, Adam. 2008. 'Opium Poppy and Informal Credit', AREU. Download PDF.

Pain, Adam. 2007. 'Water Management, Livestock and the Opium Economy: The Spread of Opium Poppy Cultivation in Balkh’, AREU. Download PDF.

Pain, Adam. 2006. 'Opium Trading Systems in Helmand and Ghor’, AREU. PDF.

Pain, Adam. 2006. 'Water Management, Livestock and the Opium Economy: Opium Cultivation in Kunduz and Balkh', AREU. Download PDF. 
Peters, Gretchen. 2009. 'How opium profits the Taliban', Peaceworks no. 62. USIP, August 2009. Download PDF.

Peters, Gretchen S. 2009. 'The Taliban and the Opium Trade', in Antonio Giustozzi (ed.) Decoding the New Taliban: Insights from the Afghan Field. Hurst/Columbia University.

PharmacoEconomics and Outcomes News. 2008. 'Legal opium production in Afghanistan?', PharmacoEconomics and Outcomes News, Volume 1, Number 553.

Pothier, Fabrice. 2009. 'Opium in Afghanistan: a reality check', in Afghanistan: Now You See Me? IDEAS Strategic Update 001. March 2009. Download PDF.

Roe, Alan. 2009. 'Water Management, Livestock and the Opium Economy Challenges and Opportunities for Strengthening Licit Agricultural Livelihoods', AREU. PDF.

Rubin, Barnett R. 2004. 'Road to ruin: Afghanistan's booming opium industry', Center for American Progress / Center on International Cooperation. Download PDF.

Rubin, Barnett R. and Alexandra Guáqueta. 2007. 'Fighting drugs and Building Peace’, Dialogue on Globalization, Occasional Paper No. 37. Download PDF.

Rubin, Barnett R. with Jake Sherman. 2008. 'Counter-narcotics to Stabilize Afghanistan: the false promise of crop eradication', CIC NYU. Download PDF.

Schweich, Thomas A. et al. 2007. 'U.S. Counternarcotics Strategy For Afghanistan, August 2007', Counternarcotics and Justice Reform in Afghanistan. Download PDF.

Scott, Richard B. 2003-2009. 'Email Memos on Helmand Counter-Narcotics: 2003Present', Scott's Helmand Valley Archives. Link to PDFs.

Scott, Richard B. 2007. 'Opium Poppy Cultivation in Central Helmand, Afghanistan: A Case Study in Bad ad Program Management, The Society for Applied Anthropology, 67th Annual Meeting. Download PDF1 PDF2.

Scott, Richard B. 2004. 'Trip report and Outline of a Strategy Paper for Central Helmand Irrigation Systems, Afghanistan’, RAMP/USAID. Download PDF.

Scott, Richard B. 2003. 'Helmand Drainage Rehabilitation Project', DAI/USAID. PDF.

Scott, Richard B. 2000. 'Helmand Initiative Socio-Economic Survey', AKBAR Survey Unit, UNDP and Helmand Planning Group. Download PDF.

SIGAR. 2009. 'Actions Needed to Resolve Construction Delays at the Counter-Narcotics Justice Center’, Special Inspector General for Afghanistan Reconstruction. PDF. 
SIGAR. 2009. 'Documenting Detention Procedures Will Help Ensure Counter-Narcotics Justice Center Is Utilized As Intended', Special Inspector General for Afghanistan Reconstruction. Download PDF.

Spivack, David (ed.). 2005. 'Feasibility study on opium licensing in Afghanistan: for the production of morphine and other essential medicines', Senlis Council. Download PDF.

Stokes, James Jagers. 2008. The causal dynamics of drug production in Afghanistan and Pakistan. Thesis (M.A.)--University of Virginia.

Theuss, Marc. 2006. 'Changing patterns of local governance in two Afghan Badakhshani border districts: the impact of heroin and opium', SOAS. Download PDF.

Todd, C.S., N. Safi, S.A. Strathdee. 2005. 'Drug Use and Harm Reduction in Afghanistan’, Harm Reduction Journal, Volume 2, Number 13. Download PDF.

Trace, M. 2005. 'The Taliban and opium cultivation in Afghanistan', International Journal of Drug Policy, Volume 16, Number 2: pages 79-80.

United States Senate. 2009. 'Afghanistan's Narco War: Breaking the Link Between Drug Traffickers and Insurgents’, Senate Committee on Foreign Relations. Download PDF.

UNODC. 2010. ‘Afghanistan Opium Survey 2010’, United Nations Office on Drugs and Crime. Download PDF.

UNODC. 2009. 'Afghanistan Opium Survey 2009: Summary Findings.’ Download PDF.

UNODC. 2008. ‘Afghanistan opium Survey 2008', UNODC. Download PDF.

UNODC. 2008. 'Discussion Paper: Is poverty driving the Afghan opium boom?', UNODC Discussion Paper. Download PDF.

UNODC. 2008. 'Afghanistan, Iran and Pakistan: Border Management Cooperation in Drug Control’, UNODC Report. Download PDF.

UNODC. 2007. ‘Securing Central Asia’s Borders with Afghanistan.’ PDF.

UN Office on Drugs and Crime. 2007. 'Targeting Precursors used in Heroin Manufacture’, United Nations Office on Drugs and Crime. Download PDF.

UN Office on Drugs and Crime. 2008. 'Afghanistan: Opium Poppy Free Road Map and Provincial Profiles’, United Nations Office on Drugs and Crime. Download PDF.

UNODC. 2007. ‘Afghanistan Opium Survey 2007’, UN Office on Drugs and Crime. PDF.

UN Office on Drugs and Crime. 2006. ‘Afghanistan opium survey 2006.’ PDF. 
UN Office on Drugs and Crime. 2006. 'Afghanistan: opium rapid assessment survey', UNODC (February 2006). Download PDF.

UN Office on Drugs and Crime. 2005. 'The opium situation in Afghanistan', UNODC (August 2005). Download PDF.

UN Office on Drugs and Crime. 2005. ‘Afghanistan: drug use survey 2005.’ PDF.

UN Office on Drugs and Crime. 2004. ‘Afghanistan: Opium Survey 2004.’ PDF.

United Nations Office on Drugs and Crime (UNODC). Afghanistan. Farmers' Intentions Survey 2003/2004. Vienna: United Nations Office on Drugs and Crime. Download PDF.

UN Office on Drugs and Crime. 2003. ‘Afghanistan: Opium Survey 2003.’ PDF.

UNODC. 2003. ‘The Opium Economy in Afghanistan: An International Problem.’ PDF.

Macdonald, D. 2003. ‘An Assessment of Problem Drug Use in Kabul City’, Community Drug Profile \#5. Vienna: United Nations Office on Drugs and Crime. Download PDF.

Ward, Christopher, et al. 2008. 'Afghanistan: Economic Incentives and Development Initiatives to Reduce Opium Production’, United Kingdom’s Department for International Development (DFID) and the World Bank. Download PDF.

World Bank. 2008. 'Afghanistan: Economic Incentives and Development Initiatives to Reduce Opium Production’, World Bank and UK’s DFID. Download PDF.

Yeo, Jason Shengming. 2007. Climate and demography: new angles for medium- and long- term national policy approaches to illicit opium poppy cultivation in Afghanistan. Thesis (B.A., Honors)--Harvard University, 2007. 


\section{Land: Environment, Agriculture, Property Issues, and Natural Resources}

\section{$\underline{\text { Books }}$}

Ahmadi, Mumtaz A. and Robin Saha. 2009. Recommendations for Drinking Water Supply and Sanitation Projects: An Assessment of Water Related Environmental Health Impacts in the Bagrami District of Kabul Province, Afghanistan. VDM Verlag.

Allan, Nigel J. R. 1978, 1979. Men and crops in the central Hindukush. Dissertation Thesis--Syracuse University.

Azam, Ghulam Farouq. 1999. The effects of local, regional and global politics on the development of the Helmand-Arghandab Valley of Afghanistan. London, England.

Baron, Loyd I. Z. 1975. The water supply constraint: an evaluation of irrigation projects and their role in the development of Afghanistan. PhD Dissertation, McGill University.

Hagen, E. and J. F. Teufert. 2009. Flooding in Afghanistan: A Crisis in Threats to Global Water Security. Springer Netherland.

Pain, Adam and Jacqueline Sutton (eds.) 2008. Reconstructing Agriculture in Afghanistan. FAO/Practical Action.

Wesa, Tooryalai. 2009. Afghan Agricultural Extension System: The Impact of Neglect and Prospects for the Future. LAP Lambert Academic Publishing.

\section{Articles, reports, and book chapters}

Abidi, A.H.H. 1977. 'Irano-Afghan Dispute over the Helmand Waters', International Studies, Vol. 16, No. 3.

Afghanistan Government. 2004. 'Securing Afghanistan’s future: accomplishments and the strategic path forward: natural resources’, (January 2004). Download PDF.

Ahmad, Masood and M. Wasiq. 2004. 'Water Resource Development in Northern Afghanistan and its Implications for Amu Darya Basin’, Washington, DC: World Bank. 
Altai Consulting. 2005-8. 'Market Sector Assessments - Afghanistan: flour, gemstones, renewable energy, etc.’, USAID/ASMED and UNDP. Link to PDFs.

Anderson, Ian McAllister. 2006. 'Water Management, Livestock and the Opium Economy: Irrigation Systems’, AREU. Download PDF.

AREU. 2006. 'Water Management, Livestock and the Opium Economy: Annotated Bibliography’, AREU. Download PDF.

Asian Development Bank. 2002. 'Afghanistan: natural resources and agricultural sector comprehensive needs assessment', (July 2002). Download PDF.

Aslami, Nadia. 2009. Carbon Sequestration, Sustainable Development and the Kyoto Protocol's Clean Development Mechanism: Implications for Reforestation Projects in Afghanistan. Master's degree, University of Denver, Download PDF.

Azimi, Ali and David McCauley. 2002. ‘Afghanistan’s environment in transition', Asian Development Bank (December 2002). Download PDF.

Azizi, Pir M. 2002. 'Special lecture on water resources in Afghanistan', Lecture at Tskuba University, Japan. Download PDF.

Balland, Daniel. 1985. 'Fromages traditionnels et fromages industriels d'Afghanistan', Production pastorale et sociétés, No 17, p. 13-26.

Balland, Daniel. 1976. 'Passé et présent d'une politique des barrages dans la région de Ghazni’, Studia Iranica, t. 5, fasc. 2, p. 238-253.

Barfield, Thomas J. 2004. 'Nomadic Pastoralists in Afghanistan: Reconstruction of the Pastoral Economy’, Bank Information Center Report. Download PDF.

Batson, Douglas E. 2008. Registering the Human Terrain: A Valuation of Cadastre. National Defense Intelligence College, Washington, DC. Download PDF.

Bedunah Donald J. 2005. 'An analysis of Afghanistan's rangelands and management issues for the development of policy and strategies for sustainable management', Chemonic International.

Bonnier, John J. M. 2007. 'Study on Dairy Production and Processing in Afghanistan For the Horticulture and Livestock Project/HLP Ministry of Agriculture, Irrigation and Livestock', Afghanistan Mission Report. Download PDF.

Borcherdt, Edward, et al. 2008. 'Winning the Invisible War: An Agricultural Pilot Plan for Afghanistan’, Center for Technology and National Security Policy. Download PDF.

Brandolini, G. V. 2006. 'Options for market and the State in Afghan Agriculture’, 
Journal of Agriculture and Environment for International Development, Vol. 100 (1/2).

Breckle, S. and W. Frey. 1974. 'Die Vegetationsstufen im Zentralen Hindukusch', Afghanistan Journal, Vol. 1, Issue 3, pp. 75-80.

Brice, Charles. 2009. 'Team Works To Improve Irrigation In Afghanistan', The Military Engineer, Vol.101 (658).

Bruno, Greg. 2009. 'Nourishing Afghanistan's Agricultural Sector', Council on Foreign Relations. Read online.

Burta, Murray and Bilha Joy Keiru. 2011. 'Strengthening post-conflict peacebuilding through community water-resource management: case studies from Democratic Republic of Congo, Afghanistan and Liberia', Water International, Vol. 36, Issue 2.

Caas Francis, David Jensen, and Yoko Hagiwara. 2005. 'Afghanistan on the brink on natural disaster', Environment and Poverty Times, No. 3. Download PDF.

Christoplos, Ian. 2004. 'Out of Step? Agricultural Policy and Afghan Livelihoods', AREU. Download PDF.

Coke, Alexia. 2004. 'Wheat Seed and Agriculture Programming in Afghanistan: Its Potential to Impact on Livelihoods', AREU. Download PDF.

CPDH. 2011. 'Afghanistan Human Development Report (AHDR): The Forgotten Front: Water Security and the Crisis in Sanitation', Center for Policy and Human Development. Download PDF.

Dupaigne, Bernard. 1977. 'Du Kârêz aux puits dans le nord de l’Afghanistan', Revue géographique de l’Est, XVII, 1-2, janv.-juin 1977, p. 27-36.

Dupaigne, Bernard. 1981. 'Le gaz afghan. Le pétrole en Afghanistan. Les projets’, p. 912 et 20-22, in :"Les intérêts économiques de l'URSS en Afghanistan", études réunies par B. Dupaigne, Paris, Les Nouvelles d'Afghanistan, 7, novembre 1981, p. 9-32.

Emadi, Mohammad Hossein. 2007. 'Pro-poor Development Policy and Natural Resource Management in Post-Conflict Afghanistan: Changes and Challenge', Proceedings: International Conference on Poverty Reduction and Forests, Bangkok. Download PDF.

FAO. 2008. 'Proceedings of Workshop on "Food Processing: Sharing lessons learnt"', Food and Agriculture Organization of the United Nations. Download PDF.

FAO. 2008. 'Rapid market analysis tool kit for fruits, vegetables and food processing', Food and Agriculture Organization of the United Nations. Download PDF. 
FAO. 2008. 'Improved Feeding Practices and Recipes For Afghan Children and Mothers', Food and Agriculture Organization of the United Nations. Download PDF.

FAO. 2008. 'Afghanistan: National Livestock Census, 2002-2003', Food and Agriculture Organization of the United Nations. Link to PDF.

FAO. 2007. 'Afghan family nutrition guide', Food and Agriculture Organization of the United Nations. Download PDF.

FAO. 2006. 'Proceedings of poultry meeting', Food and Agriculture Organization of the United Nations. Download PDF.

FAO. 2005. 'Sharing Models and Lessons Learnt on Producer Organizations: Community Groups in Afghanistan', Food and Agriculture Organization of the United Nations. PDF.

FAO. 2005. 'Afghanistan: Global Forest Resources Assessment Country Reports', Food and Agriculture Organization of the United Nations. Download PDF.

FAO. 2005. 'Afghanistan: Agriculture Prospects Report - October/November 2005’, ESA Technical Field Reports. Food and Agriculture Organization - UN. Link to PDF.

FAO. 2005. 'Afghanistan: Agriculture Prospects Report - September/October 2005', ESA Technical Field Reports. Food and Agriculture Organization - UN. Link to PDF.

FAO. 2005. ‘Afghanistan : Agriculture Prospects Report - June/July 2005’, ESA Technical Field Reports. Food and Agriculture Organization- UN. Link to PDF.

FAO. 2004. 'Contribution to Food Aid Policy Development for Afghanistan - Wheat balance by region and province: July 2003 - June 2004', Food and Agriculture Organization of the United Nations. Download Word doc.

FAO. 2003. 'Afghanistan: Survey of the horticulture sector', Food and Agriculture Organization of the United Nations. Link to PDF.

FAO. 2003. 'National Crop Output Assessment - Second Phase', Food and Agriculture Organization of the United Nations. Download PDF.

FAO. 2003. 'National Crop Output Assessment', Food and Agriculture Organization of the United Nations. Download PDF.

Favre, Raphy and Golam Monowar Kamal. 2004. Watershed Atlas of Afghanistan, Vol. I and II, AIZON, Kabul. Link to PDFs.

Favre, Raphy. 2005. 'Political Economy of wheat Prices in Afghanistan', AIZON publication, Kabul. Download PDF. 
Favre, Raphy. 2004. 'Review of the Wheat Seed Sector in Afghanistan', AIZON publication, Kabul. Download PDF.

Favre, Raphy. 2004. 'Review of relevant surveys data in the livestock/dairy sector and their implications in programming’, AADP.

Favre, Raphy. 2003. 'Grazing Land Encroachment: Joint Helicopter Mission to Dasht-e Laili', Food and Agriculture Organization of the United Nations. Download PDF.

Fitzherbert, Anthony. 2007. 'Water Management, Livestock and the Opium Economy: Livestock Feed and Products’, AREU. Download PDF.

Fitzherbert, Anthony. 2006. 'Water Management, Livestock and the Opium Economy: Animal Husbandry’, AREU. Download PDF.

Flaming, Lorene and Alan Roe. 2009. 'Opportunities for Pro-Poor Agricultural Growth' AREU. Download PDF.

Gebremedhin, Yohannes. 2007. 'Afghanistan Capacity Building for Land Policy and Administration Reform, Land Tenure and Administration in Rural Afghanistan: Legal Aspects', Terra Institute. Download PDF.

Gebremedhin, Y. 2006. 'Legal Issues Pert. to Land Titling and Regist. in Afghanistan Land Titling and Economic Restructuring in Afghanistan’, Terra Institute. PDF.

Gebremedhin, Yohannes. 2005. 'Preliminary Assessment of Informal Settlements in Kabul City.’ Download PDF.

Gebremedhin, Yohannes. 2005. 'Legal Issues in Afghanistan Land Titling and Registration in Afghanistan', Terra Institute. Download PDF.

Gentelle, Pierre. 2009. 'Sans Carte, Pas d’Analyse de Paysage en Iran et en Afghanistan, comprendre l'organisation agricole des réseaux de qanat et de karez, conduites d'eau souterraines dans les steppes et déserts’, Le Monde des cartes, No. 201.

GRAIN. 2009. 'The soils of war: the real agenda behind agricultural reconstruction in Afghanistan and Iraq; US corporate interests and the war on terror.' Download PDF.

Huntzinger, E. 2007. 'Aynak Copper Mine: Opportunities and Threats for Development from a Sustainable Business Perspective', Integrity Watch Afghanistan. Link to PDF.

Kelly, Allen T. et al. 2003. 'Rebuilding Afghanistan’s agriculture sector', Asian Development Bank report (April 2003). Download PDF.

Kugbei, Sam and Shahabuddin Shahab. 2007. 'Analysis of the Seed Market in Afghanistan', Food and Agriculture Organization of the United Nations. Download PDF. 
Kubei, Sam. 2008. 'Small-scale Seed Enterprise Start-up and Management', Food and Agriculture Organization of the United Nations. Link to PDF.

Kulke, H. 1976. 'Die Lapislazuli-Lagerstätte Sare Sang (Badakhstan). Geologie, Entstehung, Kulturgeschichte und Bergbau’, Afghanistan Journal, Vol. 3, Issue 2.

Lee, Jonathan L. 2007. 'Water Management, Livestock and the Opium Economy: The Performance of Community Water Management Systems’, AREU. Download PDF.

Lee, Jonathan L. 2006. 'Water Management, Livestock and the Opium Economy: Social Water Management', AREU. Download PDF.

Levin, Andrew. 2009. 'Agriculture and stability in Afghanistan’, USAID. Download PDF.

Levitt, E. et al. 2009. 'A community food system analysis as formative research for a comprehensive anemia control program in Northern Afghanistan’, Food Security, 1(2).

Loertscher, Steven Glade. 2008. Department of Defense environmental policy in Afghanistan during Operation Enduring Freedom. Thesis (LL.M.)--George Washington University Law School.

Mack, Thomas J. et al. 2009. 'Conceptual Model of Water Resources in the Kabul Basin, Afghanistan’, USGS/USAID. Link to PDF.

Mahmoodi, Sultan Mahmood. 2008. 'Integrated Water Resources Management for Rural Development and Environmental Protection in Afghanistan', Journal of Developments in Sustainable Agriculture, Vol. 3, No. 1. Download PDF.

Maletta, Hector and Raphy Favre. 2003. 'Agriculture and food production in post-war Afghanistan: A report on the winter agricultural survey 2002-2003', ESA Technical Field Reports. Food and Agriculture Organization of the United Nations. Link to PDFs.

Maletta, Hector E. 2007. 'Arable Land Tenure in Afghanistan in the Post-Taliban Era', African and Asian Studies, Vol. 6. Link to PDF.

Maletta, Hector. 2002. 'Wages of war, wages of peace: Food prices and unskilled labour pay in Afghanistan, 1996-2002’, ESA Working Paper. Food and Agriculture Organization of the United Nations. Link to PDF.

McEwen, Alec and Sharna Nolan. 2007. 'Water Management, Livestock and the Opium Economy: Options for Land Registration', AREU. Download PDF.

McEwen, Alec and Brendan Whitty. 2006. 'Water Management, Livestock and the Opium Economy: Land Tenure’, AREU. Download PDF. 
Munib, Bashir. 2005. 'Law of Land Tenure and Transfer of Property in Times of War', in The Shari'a in the Constitutions of Afghanistan, Iran and Egypt: Implications for Private Law. Edited by Nadjma Yassari. Tubingen: Mohr Siebeck.

Nyborg, I. et al. 2008. 'Exploring rural livelihoods in Afghanistan: a study of 10 villages in Dai Kundi Province’, Noragric. Download PDF.

Pain, Adam. 2009. 'Policymaking in Agricultural and Rural Development', AREU. PDF.

Pain, Adam. 2004. 'Understanding Village Institutions: Case Studies on Water Management from Faryab and Saripul’, AREU. Download PDF.

Pain, Adam and Sayed Mohammad Shah. 2009. 'Policymaking in Agriculture and Rural Development in Afghanistan’, AREU. Download PDF.

Parker, Kevin. 2009. 'Surrounded by riches, Afghanistan seeks to mine its own', Hart's E\&P, Vol. 82, No. 5.

Patterson, Mervyn. 2004. 'The Shiwa Pastures, 1978 - 2003: Land Tenure Changes and Confict in Northeastern Afghanistan’, AREU. Download PDF.

Pinera, Jean-François and Robert A. Reed. 2009. 'A tale of two cities: restoring water services in Kabul and Monrovia’, Disasters, Vol. 33, No. 4.

Renner, Michael. 2009. 'Water Challenges in Central-South Asia', Norwegian Peacebuilding Centre. Download PDF.

Robinett, Daniel et al. 2008. 'Central Afghanistan Rangelands: A History of Tribal Rule, Grazing, War, and Rebuilding’, Rangelands, Vol. 30, No. 4.

Roe, Alan. 2008. 'Natural Resources Management, Farming Systems and Rural Livelihoods’, AREU. Download PDF.

Roe, Alan. 2006. 'Water Management, Livestock and the Opium Economy: Baseline Survey', AREU. Download PDF.

Rout, Bob. 2008. 'How the Water Flows: A Typology of Irrigation Systems in Afghanistan’, AREU. Download PDF.

Saba, Daud. 2005. 'Environment', in Arne Strand and Gunnar Olesen (editors), 'Afghanistan: findings on education, environment, health, gender, livelihood, and water and sanitation (2001-early 2005)', CMI Report, No. 15. Download PDF.

Salam, Akram. 'Evaluation of Community Based Upgrading Method for Improving Informal Settlements’, Terra Institute. Download PDF. 
Scanagri Denmark A/S. 2007. 'Islamic Republic of Afghanistan: Capacity Building in Land Policy and Administration Reform’, Terra Institute. Download PDF.

Sene, Amath Pathe M. 2006. 'Case Study of Roy-e-Doab District Samangan Province, Afghanistan', URD/Solidarites. Download PDF.

Sharif, Mohammad, M. Yasin Safar. 2008. 'Land Administration and Management in Afghanistan’, Terra Institute. Download PDF.

Sørbø, G. M. 2007. 'Land issues and poverty reduction: requirements for lasting peace in Sudan and Afghanistan', International Food Policy Research Institute. Download PDF.

Stanfield, David J. 2007. 'Project Brief: Summary Description of the Rural Land Administration Project and Recommendations for Future Similar Activities', Terra Institute. Download PDF.

Stanfield, David J. 2006. 'Land Administration in (Post) Conflict Conditions: The Case of Afghanistan', Terra Institute. Download PDF.

Stanfield, David J. 2006. 'Upgrading of the Property Rights Recording System of Afghanistan’, Terra Institute. Download PDF.

Stanfield, J. D., M.Y. Safar and A. Salam. 2008. 'Community Rangeland Administration: Focus on Afghanistan’, IASC. Download PDF.

Stanfield, J. D. et al. 2008. 'Community-State Relations: Ownership of Rural Property Records in Afghanistan’, IASC. Download PDF.

Stanfield, David J. et al. 2005. 'Description of Procedures for Producing Legal Deeds to Record Property Transactions in Afghanistan’, Terra Institute. Download PDF.

Taylor, David A. 2003. 'Environmental Triage in Afghanistan,' Environmental Health Perspectives, Vol. 111, No. 9 (July 2003). Download PDF.

Thomas, Vincent and Mujeeb Ahmad. 2009. 'A Historical Perspective on the Mirab System: A Case Study of the Jangharoq Canal, Baghlan’, AREU. Download PDF.

Thompson, J. T. et al. 2009. 'Snow harvesting: a potential water source for Afghanistan', Cold Regions Research and Engineering Laboratory. Download PDF.

Thomson, Euan. 2007. 'Water Management, Livestock and the Opium Economy: Livestock Marketing’, AREU. Download PDF.

Thomson, Euan. 2006. 'Water Management, Livestock and the Opium Economy: Livestock Production and Health', AREU. Download PDF. 
Toderich, Kristina and Tsuneo Tsukatani. 2004. 'A survey of land, vegetation and irrigation systems in North Afghanistan and neighboring Tajikistan’, Kyoto Institute of Economic Research. Discussion Paper No. 584. Download PDF.

Uhl, V.H. 2006. 'Afghanistan: An Overview of Ground Water Resources and Challenges’, Ground Water, 44(5), (Sept.-Oct. 2006).

United Nations Environment Programme. 2008. ‘Afghanistan’s Environment 2008', UN Environment Programme. Download PDF.

United Nations Environment Programme. 2003. 'Post-conflict environmental assessment: Afghanistan', UNEP. Download PDF.

United Nations Environment Programme. 2003. ‘Afghanistan: Wakhan mission technical report', UNEP (July 2003). Download PDF.

Wily, Liz Alden. 2004. 'Land Relations in Bamyan Province: Findings from a 15 Village Case Study’, AREU. Download PDF.

Wily, Liz Alden. 2004. 'Land Relations in Faryab Province', AREU. Download PDF.

Wily, Liz Alden. 2004. 'Looking for Peace on the Pastures: Rural Land Relations in Afghanistan’, AREU. Link to PDF.

Wily, Liz Alden. 2004. 'Putting Rural Land Registration in Perspective: The Afghanistan Case', AREU. Download PDF.

Wily, Liz Alden. 2003. 'Land and the Constitution', AREU. Download PDF.

Wily, Liz Alden. 2003. 'Land Rights in Crisis: Addressing Tenure Insecurity in Afghanistan’, AREU. Download PDF.

Yeager, James R. et al. 2009. 'The Aynak Copper Tender: Implications for Afghanistan and the West', Skyline Laboratories. Link to PDF.

Zonn, I.S. 2002? 'Water resources of northern Afghanistan and their future use', Soyuzvod Project. Download PDF. 


\section{Human rights}

Afghanistan Independent Human Rights Commission. 2009. ‘AIHRC-UNAMA Joint Monitoring of Political Rights - Presidential and Provincial Council Elections', Third Report [1 August - 21 October 2009]', AIHRC/ UNAMA. Download PDF.

Afghanistan Independent Human Rights Commission. 2008. 'Justice for Children: The Situation of Children in Conflict with the Law in Afghanistan', Afghanistan Independent Human Rights Commission/UNICEF Report. Download PDF.

Afghanistan Independent Human Rights Commission. 2008. 'From Hope to Fear: An Afghan Perspective on Operations of Pro-Government Forces in Afghanistan’, Afghanistan Independent Human Rights Commission. Download PDF.

Afghanistan Independent Human Rights Commission. 2008. 'Economic and Social Rights Report in Afghanistan-III.’ Download PDF.

Afghanistan Independent Human Rights Commission. 2007. 'Violations of International Humanitarian Law in Afghanistan: Practices of Concern and Example Cases 2007.’ PDF.

Afghanistan Independent Human Rights Commission. 2007. 'Investigation: Use of indiscriminate and excessive force against civilians by US forces following a VBIED attack in Nangahar province on 4 March 2007.' Download PDF.

Afghanistan Independent Human Rights Commission. 2007. 'AIHRC investigation into the shooting of demonstrators in Sheberghan on 28 May 2007.' Read online.

Afghanistan Independent Human Rights Commission. 2007. 'Summary of Economic \& Social Rights Report in Afghanistan.’ Download PDF.

Afghanistan Independent Human Rights Commission. 2007. 'Economic \& Social Rights in Afghanistan, 2nd Report.’ Download PDF.

Afghanistan Independent Human Rights Commission. 2006. 'Annual Report: 20052006.' Read online.

Afghanistan Independent Human Rights Commission. 2006. 'An Overview on Situation of Child Labour in Afghanistan Research Report.’ Download PDF.

Afghanistan Independent Human Rights Commission. 2006. 'Report on Economic and Social Rights.’ Download PDF. 
Afghanistan Independent Human Rights Commission. 2006 'Evaluation Report on General Situation of Women.’ Read online.

Afghanistan Rights Monitor. 2011. 'ARM Annual Report: Civilian Casualties of War January-December 2010.’ Download PDF.

Afghanistan Rights Monitor. 2011. 'ARM Annual Report: Civilian Casualties of War, January-December 2010.’ Download PDF.

Afghanistan Justice Project. 2005. 'Casting shadows: war crimes and crimes against humanity 1978-2001', The Afghanistan Justice Project, July 2005. Download PDF.

Amnesty International. 2009. 'Human Rights in Afghanistan’, Amnesty International Report. Read online.

Amnesty International. 2008. 'Human Rights in Afghanistan', Amnesty International Report. Read online.

Amnesty International. 2008. 'Afghanistan: arms proliferation fuels further abuse', AI Public Briefing. Read online.

Amnesty International. 2008. 'Getting Away With Murder? The Impunity of International Forces in Afghanistan’, Amnesty International. Download PDF.

Amnesty International. 2007. 'Human Rights in Afghanistan', Amnesty International Report. Read online.

Amnesty International. 2007. 'Afghanistan: All who are not friends, are enemies: Taleban abuses against civilians’, Amnesty International. Download PDF.

Amnesty International. 2007. 'Afghanistan Detainees transferred to torture: ISAF complicity?’ Read online.

Amnesty International. 2001. 'Afghanistan: making human rights the agenda', Amnesty International report, (November 1, 2001). Link to PDF.

Andersen, Susan and Kooij, Christina. 2007. 'Adult literacy education and human rights: a view from Afghanistan’, Globalisation, Societies and Education, Vol. 5, No. 3.

AREU. 2009. 'Confronting Child Labour in Afghanistan’, AREU. Download PDF.

ARM. 2009. 'The Winning Warlords: ARM's briefing paper on the role and influence of warlords and militia commanders in the August 2009 presidential election in Afghanistan', Afghanistan Rights Monitor. Download PDF. 
Azarbaijani-Moghaddam, Sippi. 2007. 'On Living with Negative Peace and a Half-Built State: Gender and Human Rights', International Peacekeeping, 14(1), pp. 127-142.

Beg, Bator and Ali Payam. 2010. 'Charting a Course for a Sustainable Peace:

Linking Transitional Justice and Reconciliation in Afghanistan', Afghanistan Watch. Download PDF.

Benini, Aldo A. and Lawrence H. Moulton. 2004. 'Civilian Victims in an Asymmetrical Conflict: Operation Enduring Freedom, Afghanistan', Journal of Peace Research, Vol. 41, No. 4.

Benish, Abdul J. et al 2009. Between Impunity and Accountability: A comparative overview of transitional justice processes in two post-Conflict South Asian Countries', Afghanistan Watch report. Download PDF.

Bohannon, John. 2011. 'Counting the dead in Afghanistan', Science, Vol. 331, No. 6022.

Brossel, Vincent. 2009. 'Afghanistan: What gains for press freedom from Hamid Karzai’s seven years as president?', Reporters Without Borders. Download PDF.

CIVIC. 2009. 'Losing the People: The Costs and Consequences of Civilian Suffering in Afghanistan’, Campaign for Innocent Victims in Conflict. Download PDF.

Colvin, Richard. 2009. 'Further Evidence [on detainees] of Richard Colvin to the Special Committee on Afghanistan.’ December 16. Download PDF.

Dillon, D. 2007. 'The Civilian Side Of the War on Terror', Policy Review, Oct. Online.

Drumbl, Mark A. 2002. 'The Taliban’s ‘Other’ Crimes’, Third World Quarterly, Vol. 23, No. 6.

Everts, Dan. 2009. 'Afghanistan: The right mission on the wrong footing', Security and Human Rights, Vol. 20, No. 1.

Gaston, E. L. 2008. 'Mercenarism 2.0? The Rise of the Modern Private Security Industry and Its Implications for International Humanitarian Law Enforcement', Harvard International Law Journal, Vol. 49, No. 1.

Gossman, Patricia. 2005. 'Casting Shadows: War Crimes and Crimes against Humanity, 1978-2001’, Afghan Justice Project. Download PDF.

Human Rights First. 2011. 'Detained and Denied in Afghanistan: How to Make U.S. Detention Comply with the Law.' Download PDF.

HRF. 2008. 'Private Security Contractors at War: Ending the Culture of Impunity', Human Rights First. Download PDF. 
Human Rights Watch. 2008. “"Troops in Contact”: Airstrikes and Civilian Deaths in Afghanistan’, Human Rights Watch. Download PDF.

Human Rights Watch. 2007. 'The Human Cost: The Consequences of Insurgent Attacks in Afghanistan', Human Rights Watch, Volume 19, No. 6(C), April 2007. Read online.

Human Rights Watch. 2006. 'By the Numbers: Findings of the Detainee Abuse and Accountability Project’, (April 2006) Volume 18, No. 2(G). Download PDF.

Human Rights Watch. 2005. 'Blood-stained hands: past atrocities in Kabul and Afghanistan's legacy of impunity.’ Download PDF.

Human Rights Watch. 2004. ““Enduring Freedom:” Abuses by U.S. Forces in Afghanistan ', (March 2004) Vol. 16, No. 3(C). Download PDF.

Human Rights Watch. 2004. 'The Road to Abu Ghraib’, June 2004. Download PDF.

Human Rights Watch. 2003. ' “Killing you is a very easy thing for us:” human rights abuses in southeast Afghanistan', Human Rights Watch Report, Vol. 15, No. 5(C). PDF.

Human Rights Watch. 2002. 'Closed Door Policy: Afghan Refugees in Pakistan and Iran', Vol. 14, No. 2(G). Download PDF.

Human Rights Watch. 2002. 'Fatally Flawed: Cluster Bombs and Their Use by the United States in Afghanistan', Vol. 14, No. 7 (G), December 2002. Download PDF.

Human Rights Watch. 2002. ‘Paying for the Taliban’s Crimes: Abuses Against Ethnic Pashtuns in Northern Afghanistan', Human Rights Watch Report, Vol. 14(2C). PDF.

Human Rights Watch. 2002. “ "We want to live as humans:” repression of women and girls in western Afghanistan’, Human Rights Watch Report, Vol. 14, No. 11(C). PDF.

Human Rights Watch. 2002. ، “All our hopes are crushed:” violence and repression in western Afghanistan', Human Rights Watch Report, Viol. 14, No. 7(C). Download PDF.

Human Rights Watch. 2001. 'Landmine use in Afghanistan', Human Rights Watch Backgrounder. Download PDF.

Hunte, Pamela. 2009. 'Beyond Poverty: Factors Influencing Decisions to Use Child Labour in Rural and Urban Afghanistan’, AREU. Download PDF.

IB Consultancy. 2010. ‘Afghan Schoolgirls Chemical Attacks.’ Download PDF. 
IFJ/AIJA. 2011. 'Reporting in Times of War: Press Freedom in Afghanistan 2008 2011', International Federation of Journalists // Afghan Independent Journalists Association. Download PDF.

International Crisis Group. 2003. 'Afghanistan: women and reconstruction', Asia report no. 48 (March 14, 2003). Access online.

International Organization for Migration. 2008. 'Trafficking in Persons in Afghanistan: Field Survey Report, June 2008.’ Download PDF.

International Organization for Migration. 2004. 'Trafficking in Persons: An Analysis of Afghanistan', January 2004. Download PDF.

IRIN. 2008. ‘Afghanistan: Psychological Scars of Violence On Children’, United Nations Office of Coordination of Humanitarian Affairs. Read online.

Keenan, Marla and Jonathan Tracy. 2010. 'United States Military Compensation to Civilians in Armed Conflict', CIVIC. Download PDF.

Klass, Rosanne T. 1994. 'Genocide in Afghanistan, 1978-1992', in The Widening Circle of Genocide. Israel W. Charney, (ed.). Transaction Publishers.

Laffey, Jennifer. 1999. Demographic and injury characteristics of landmine victims in Afghanistan, 1992-1996. Thesis (Ph. D.) -- University of Sydney.

Majidi, Altai and Rodolphe Baudeau. 2008. 'A Rapid Assessment on Child Labour in Kabul', ILO. Download PDF.

Mani, Rama. 2003. ‘Ending Impunity and Building Justice in Afghanistan’, AREU. PDF.

Moen, Husain and Ahmad Zia Mohammadi. 2009. 'International Criminal Court (ICC) in Afghanistan: A Report on the Consultative Meeting on Obligations of Afghanistan under (ICC)', Afghanistan Watch. Download PDF.

Mohan, Raj P. 2005. 'Genocide as a possible response to westernization: government treatment of minorities in Afghanistan and Iran', in Graham C. Kinloch and Raj P. Mohan (editors), Genocide: Approaches, Case Studies, and Responses. Algora.

MuhammedAlly, Sahr. 2009. 'Fixing Bagram: Strengthening Detention Reforms to Align with U.S. Strategic Priorities’, Human Rights First. Download PDF.

MuhammedAlly, Sahr. 2009. 'Undue Process: An Examination of Detention and Trials of Bagram Detainees in April 2009’, Human Rights First. Download PDF.

Mutasem, M. 2007. Is prosecution a preferable approach for dealing with the past human rights violations in Afghanistan? Thesis (LL. M.)--University of Washington. 
Nadery, Nader. 2009. 'A Human Rights Awakening?’, in The Future of Afghanistan, edited by J. Alexander Thier. United States Institute of Peace. Download PDF.

Nadery, Ahmad Nader. 2003. 'Afghans Struggle to Restore Justice in their Country: How Can Afghans Redress Past Abuses Without Creating New Injustices’, in Brief 28, Confronting Afghanistan’s Security Dilemma. Mark Sedra (ed.). BICC. Download PDF.

Nicholls, R and M. Glad. 2009. 'Fight Poverty to End Insecurity: Afghan perceptions of insecurity’, Human Rights Research and Advocacy Consortium report. Download PDF.

OHCHR. 2010. 'Human Rights Dimension of Poverty in Afghanistan', United Nations Office of the High Commissioner of Human Rights. Word Doc.

Oxfam. 2010. 'Nowhere to Turn: The Failure to Protect Civilians in Afghanistan', Oxfam International. Download PDF.

Pasha, Mustapha Kamal. 2009. 'Collateral Damage: Afghanistan ', Globalizations, Volume 6, Issue 1.

Pawelski, Ele. 2009. 'Defining Justice in Afghanistan: Development of a National Legal Aid System’, 27 Windsor Review of Legal and Social Issues 185.

Physicians for Human Rights. 2008. 'Broken Laws, Broken Lives: Medical Evidence of Torture by US Personnel and Its Impact’, Physicians for Human Rights. Download PDF.

Physicians for Human Rights. 2002. 'A Survey of Human Rights Abuses Among New Internally Displaced Persons, Herat, Afghanistan.’ Download PDF.

Rogers, Christopher. 2010. 'Addressing Civilian Harm in Afghanistan: Policies and Practices of International Forces’, CIVIC. Download PDF.

Rubin, Barnett R. 2003. 'Transitional justice and human rights in Afghanistan', International Affairs, Vol. 79, No. 3.

Sajjad, Tazreena. 2009. 'These Spaces in between: The Afghanistan Independent Human Rights Commission and its Role in Transitional Justice', International Journal of Transitional Justice, Vol. 3, Issue 3.

Samar, Sima. 2009. 'The Need for Justice in Peace Building', Swedish Committee for Afghanistan Conference: Peace Building in Afghanistan. Download PDF.

Scott, Craig M. 2010. 'Moral and Legal Responsibility with Respect to Alleged Mistreatment of Transferred Detainees in Afghanistan', Presentation to the House of Commons Special Committee on the Canadian Mission in Afghanistan. Link to PDF. 
Shameem, Shaista. 2010. 'Report of the Working Group on the use of mercenaries as a means of violating human rights and impeding the exercise of the right of peoples to selfdetermination', United Nations. Download PDF.

Sim, Amanda. 2009. ‘Confronting Child Labour in Afghanistan’, AREU. Download PDF.

Smith, Leanne M. 2008. 'Implementing International Human Rights Law in Post Conflict Settings - Backlash without Buy-In: Lessons from Afghanistan’, Muslim World Journal of Human Rights, Vol. 5, Issue 1.

Thier, J Alexander and Azita Ranjbar. 2008. 'Killing Friends, Making Enemies: The Impact and Avoidance of Civilian Casualties in Afghanistan Source', United States Institute of Peace. Download PDF.

UN. 2011. 'Report of the Secretary-General on children and armed conflict in Afghanistan’, United Nations Security Council. Download PDF.

UNAMA/AIHRC. 2011. 'Afghanistan: annual report 2010 - protection of civilians in armed conflict', UNAMA Human Rights and the Afghanistan Independent Human Rights Commission. Download PDF.

UNAMA. 2010. 'Afghanistan: annual report on protection of civilians in armed conflict, 2009’, UNAMA, Human Rights. Download PDF.

UNAMA. 2009. 'Arbitrary Detention in Afghanistan: A Call for Action', Vol. 1: A Practical Guide to Understanding and Combating Arbitrary Detention Practices in Afghanistan. UNAMA. Download PDF.

UNAMA. 2009. 'Afghanistan: Annual Report on Protection of Civilians in Armed Conflict [2008]’, United Nations Assistance Mission to Afghanistan. Download PDF.

UNAMA. 2009. 'Afghanistan: Mid Year Bulletin on Protection of Civilians in Armed Conflict’, United Nations Assistance Mission in Afghanistan. Download PDF.

UNAMA. 2008. 'Armed Conflict and Civilian Casualties, Afghanistan Trends and Developments’, United Nations Assistance Mission in Afghanistan. Download Word doc.

UNHCHR. 2005. 'UN Mapping Report: Afghanistan', [suppressed and unpublished UN report on human rights abuses, 1978-2001]. Download PDF.

UNHRC. 2009. 'Annual report of the United Nations High Commissioner for Human Rights and reports of the Office of the High Commissioner and Secretary-General', United Nations Human Rights Council. Download PDF.

UNSC. 2008. 'Report of the Secretary-General on children and armed conflict in Afghanistan’, United Nations Security Council. Download PDF. 
US FOIA. 2009. 'The Dasht-e-Leili Massacre of Taliban prisoners of war, US FOIA, part I, 2002-2008', US Freedom of Information Act. Download PDF. Part 2: Download PDF

Vant, Megan. 2007. In Legal Limbo? The status and rights of detainees from the 2001 war in Afghanistan. The University of Waikato. Download PDF.

Waldman, Matt. 2009. 'Caught in the Conflict: Civilians and the international security strategy in Afghanistan', A briefing paper by eleven NGOs operating in Afghanistan for the NATO Heads of State and Government Summit, 3-4 April 2009. Download PDF.

Wali, Sima. 2004. 'Violence, terror, and accountability in Afghanistan', Peace Review, Vol. 16, No. 1.

Watch List on Children and Armed Conflict. 2010. 'Setting the Right Priorities:

Protecting Children Affected by Armed Conflict in Afghanistan.’ Download PDF.

Waxman, Matthew C. 2009. 'United States Detention Operations in Afghanistan and the Law of Armed Conflict', Israel Yearbook on Human Rights, Vol. 39. Link to PDF.

Williamson, Myra. 2009. Terrorism, war and international law: the legality of the use of force against Afghanistan in 2001. Ashgate publishing.

Winterbotham, Emily. 2010. 'The State of Transitional Justice in Afghanistan: Actors, Approaches and Challenges’, AREU. Download PDF. 


\section{Women, Gender and Family}

\section{$\underline{\text { Books }}$}

Abirafeh, Lina. 2009. Gender and International Aid in Afghanistan: The Politics and Effects of Intervention. McFarland.

Akbar, Alia Rawi. 2009. Afghan Women: Under the Shadow of Terror and Politics. Metropolitan publishing.

Armstrong, Sally. 2008. Bitter Roots, Tender Shoots: The Uncertain Fate of Afghanistan's Women. Viking Canada.

Armstrong, Sally. 2002. Veiled Threat: The Hidden Power of Women in Afghanistan. NY: Four walls Eight Windows.

Bernard, Cheryl. 2002. Veiled Courage: Inside the Afghan Women's Resistance. New York: Broadway books.

Brodsky, Anne. 2003. With All Our Strength: The Revolutionary Association of the Women of Afghanistan. New York: Routledge.

Centlivres, Pierre and Micheline Centlivres-Demont 2010. Afghanistan on the Threshold of the 21st Century: Three Essays on Culture and Society. Markus Wiener Publishers.

Doubleday, Veronica. 1990. Three Women of Herat. University of Texas Press.

Ellis, Deborah. 2000. Women of the Afghan War. Praeger.

Emadi, Hafizullah. 2002. Repression, Resistance and Women in Afghanistan. Praeger.

Grima, Benedicte. 1992. The Performance of Emotion Among Paxtun Women: “The Misfortunes Which Have Befallen Me.” Austin, TX: University of Texas Press.

Heath, Jennifer and Ashraf Zahedi (editors). 2011. Land of the Unconquerable: The Lives of Contemporary Afghan Women. University of California Press.

Joya, Malalai. 2009. A Woman Among Warlords: The Extraordinary Story of an Afghan Who Dared to Raise Her Voice. Scribner.

Rostami-Povey, Elaheh. 2007. Afghan Women: Identity and Invasion. Zed Books. 
Samad, Khorshied. 2009. Afghan Women, Media and Emerging Democracy: Social Evolution in Post-Taliban Afghanistan. VDM Verlag.

Shavarini, M. and W. Robison. 2005. Women and education in Iran and Afghanistan: an annotated bibliography of sources in English, 1975-2003. Lanham, MD: Scarecrow Press.

Skaine, Rosemarie. 2008. Women of Afghanistan In The Post-Taliban Era: How Lives Have Changed and Where They Stand Today. McFarland.

Skaine, Rosemarie. 2002. The Women of Afghanistan Under the Taliban. McFarland.

Tapper, Nancy. 1991. Bartered Brides: Politics, Gender and Marriage in an Afghan Tribal Society. Cambridge, UK: Cambridge University Press.

\section{$\underline{\text { Articles, reports and book chapters }}$}

Afghanistan Independent Human Rights Commission. 2006 'Evaluation Report on General Situation of Women.’ Read Online.

Aktar, Cengiz. 2000. ‘Afghanistani Women’s Plight’, Anthropology News 41(2): 36.

Anderson. Jon W. 1982. 'Social structure and the veil: comportment and interaction in Afghanistan’, Anthropos, Vol. 77.

AREU. 2007. 'Family Dynamics and Family Violence Conference Presentation 11, July 2007’ AREU. Download PDF.

Azarbaijani-Moghaddam, Sippi. 2009. 'The Arrested Development of Afghan Women', in The Future of Afghanistan, ed. by J. Thier. USIP. Download PDF.

Azerbaijani-Moghaddam, S. 2006. 'Gender in Afghanistan’, in Promoting Democracy under Conditions of State Fragility: Afghanistan. Heinrich Boll. Download PDF.

Barakat, Sultan and Wardell Gareth. 2002. 'Exploited by Whom? An Alternate perspective on Humanitarian Assistance to Afghan Women’, Third World Quarterly, 23.

Basiri, Sadiqa. 2003. 'Gender and Security Issues: Women in Afghanistan', pp. 54-61 in Brief 28, Confronting Afghanistan’s Security Dilemma, Mark Sedra (ed.). BICC.

Download PDF.

Benard, Cheryl, Seth G. Jones, Olga Oliker, Cathryn Quantic Thurston, Brooke K. Stearns, Kristen Cordell. 2007. 'Women and Nation-Building', RAND. Download PDF.

Benard, Cheryl Kristen Cordell and Olga Oliker. 2007. 'Women and Human Security: The Case of Post-Conflict Afghanistan', RAND Corporation. Download PDF. 
Bickel, Beverly. 2003. 'Weapons of Magic: Afghan Women Asserting Voice via the Net', Journal of Computer-Mediated Communications, Vol. 8 No. 2.

Boeson, Inger W. 1980. 'Women, Honour and Love: Some Aspects for the Pashtu Woman’s Life in Eastern Afghanistan', Afghanistan Journal, 7(2): pp. 50-59.

Borchgrevink, Kaja et al. 2008. 'Peacebuilding in Afghanistan: How To Reach the Women’, International Peace Research Institute. Download PDF.

Boros, R. 2008. 'Afghan women entrepreneurs: at the crossroads between globalisation and local traditions', International Journal of Business and Globalisation, Vol. 2, No. 4.

Centlivres, Pierre, and Michelene Centlivres-Demont. 1994. 'Afghan Women in Peace, War, and Exile', in The Politics of Social Transformation in Afghanistan, Iran, and Pakistan. M. Weiner and A.O. Banuazizi, eds. Syracuse University Press.

Clifford, James. 1997. ‘Afghanistan’s Women: A Confused Future’, Refugees II(108).

Cole, Juan. 2008. 'The Taliban, Women, and the Hegelian Private Sphere’, in R. Crews and A. Tarzi (eds). The Taliban and the Crisis of Afghanistan. Harvard University Press.

Daulatzai, Anila. 2008. 'The Discursive Occupation of Afghanistan', British Journal of Middle Eastern Studies, Volume 35, Number 3.

Dossa, Parin. 2010. 'Exploring the Disjuncture Between the Politics of Trauma and Everyday Realities of Women in Afghanistan', Journal of Muslim Mental Health, Volume 5, Issue 1.

Echavez, Chona R. 2010. 'Does Women's Participation in the National Solidarity Programme Make a Difference in their Lives? A Case Study in Parwan Province’, AREU. Download PDF.

Fleschenberg, Andrea. 2009. ‘Afghanistan’s parliament in the making: Gendered understandings and practices of politics in a transitional country', Heinrich Böll Foundation and UNIFEM. Download PDF.

Fluri, Jennifer L. 2009. 'Geopolitics of gender and violence 'from below', Political Geography, Vol. 28.

Fluri, Jennifer L. 2009. 'The beautiful 'other': a critical examination of 'western' representations of Afghan feminine corporeal modernity', Gender, Place \& Culture, Vol. 16, No. 3.

Fluri, Jennifer L. 2008. 'Feminist-nation building in Afghanistan: an examination of the Revolutionary Association of the Women of Afghanistan’, Feminist Review, Vol. 89. 
Fluri, Jennifer L. 2006. "'Our Website Was Revolutionary" Virtual Spaces of Representation and Resistance', ACME: An International E-Journal for Critical Geographies, Vol. 5, No. 1. Download PDF.

Goodson, Larry P. 2001. 'Perverting Islam: Taliban social policy toward women', Central Asian Survey, 20(4), pp. 415 - 426.

Grace, Jo. 2005. 'Who Owns the Farm? Rural Women’s Access to Land and Livestock', AREU. Online. Download PDF.

Grace, Jo. 2004. 'Gender Roles in Agriculture: Case Studies of Five Villages in Northern Afghanistan’, AREU. Download PDF.

FNAW. 2009. 'Getting it Right: Security, Peace and Development for Afghan Women', The Funder's Network for Afghan Women. Download PDF.

Haider, S. et al. 2009. 'Childbearing and contraceptive decision making among Afghan men and women: a qualitative analysis’, Contraception, Vol. 78, Issue 2.

Hanifi, M. 1982. 'Cultural values and family relations in Kamari, Afghanistan', Afghanistan Journal, Vol. 9, Issue 2, pp. 48-52.

Hassan, Palwasha. 2010. 'The Afghan Peace Jirga: Ensuring that Women are at the Peace Table’, USIP Peacebrief, No. 29. Download PDF.

Hatch Dupree, Nancy. 2004. 'The Family during Crisis in Afghanistan’, Journal of Comparative Family Studies, Vol. 35.

Hatch-Dupree, Nancy. 1998. 'Afghan Women under the Taliban', in Fundamentalism Reborn? Afghanistan and The Taliban. William Maley (editor). NY: NYU Press.

Hatch-Dupree, Nancy. 1992. 'Afghanistan: Women, Society and Development', Journal of developing Societies, 8(1), pages 30-42.

Hatch Dupree, Nancy. 1989. 'Seclusion or service: will women have a role in the future of Afghanistan’, Occasional Paper No 29, December 1989, Peshawar, Pakistan.

Hatfield, Jennifer et al. 2008. ‘Women’s Participation in Domestic Violence Health Policy Development: Afghanistan Component', Women’s Domestic Violence Health Project. Download PDF.

Hirschkind, Charles and Saba Mahmood. 2002. 'Feminism, the Taliban, and Politics of Counter-Insurgency’, Anthropological Quarterly, Vol. 75, No. 2.

Hoodfar, Homa. 2007. 'Women, religion and the 'Afghan Education Movement' in Iran', Journal of Development Studies, Vol. 43, No. 2, pp. 265-293. 
Howard-Merriam, K. 1987. 'Afghan Refugee Women and Their Struggle for Survival', in Afghan Resistance: The Politics of Survival. G. Farr and J. Merriam, eds. Westview.

Human Rights Watch. 2009. "We Have the Promises of the World”: Women's Rights in Afghanistan', Human Rights Watch. Download PDF.

Human Rights Watch. 2002. “ "We want to live as humans:” repression of women and girls in western Afghanistan’, Human Rights Watch Report, Vol. 14, No. 11(C). PDF.

Hyder AA, E. Tsui and Z. Noor. 2007. 'Intimate partner violence among Afghan women living in refugee camps in Pakistan’, Soc Sci Med, April 64(7): pp. 1536-47.

International Crisis Group. 2003. 'Afghanistan: women and reconstruction', Asia report no. 48 (March 14, 2003). Access online.

Kakar, Palwasha. (n.d.) 'Tribal Law of Pashtunwali and Women’s Legislative Authority', Afghan Legal History Project, Harvard Law School. Download PDF.

Kamal, Sarah. 2004. ‘Disconnected from Discourse Women’s Radio Listening in Rural Samangan, Afghanistan’, Working Paper \#26, June 2004. Download Word Doc.

Kamali, Mohammad Hashim. 2008. 'References to Islam and Women in the Afghan Constitution', Arab Law Quarterly, Volume 22, Number 3.

Kandiyoti, Deniz. 2009. 'The lures and perils of gender activism in Afghanistan ', The Anthony Hyman Memorial Lecture, SOAS. Download PDF.

Kandiyoti, Deniz. 2007. 'Old Dilemmas or New Challenges? The Politics of Gender and Reconstruction in Afghanistan', Development and Change, Vol. 38, No. 2, pp. 169-199.

Kandiyoti, Deniz. 2005. 'The Politics of Gender and Reconstruction in Afghanistan', UN Research Institute for Social Development, Occasional Paper \#4. Download PDF.

Kaur, Harjot and Najla Ayubi. 2008. 'Status of Women in Afghanistan', in State Building, Security, and Social Change in Afghanistan: Reflections on a Survey of the Afghan People. The Asia Foundation. Download PDF.

Knabe, E. 1977. 'Frauenemanzipation in Afghanistanl. Ein empirischer Beitrag zur Untersuchung von soziokulturellem Wandel und sozio-kultureller Bestandigkeit,' Afghanische Studien Bd. 16 (Meisenheim am Glan: Verlag Anton Hain)

Kouvo, Sari. 2008. ‘A ‘Quick and Dirty’ Approach to Women’s Rights - A Case Study of Afghanistan’, Feminist Legal Studies, No. 16. 
Kouvo, Sari et al. 2009. 'Addressing Gender-Specific Violations in Afghanistan’, International Centre for Transitional Justice. Download PDF.

Larson, Anna. 2008. 'A Mandate to Mainstream: Promoting Gender Equality in Afghanistan', AREU. Download PDF.

Lee, Jennifer Kristen. 2009. 'Comment: Legal Reform to Advance the Rights of Women in Afghanistan within the Framework of Islam’, Santa Clara Legal Review, Vol. 49 (2).

Maletta, Hector. 2008. 'Gender and Employment in Rural Afghanistan, 2003-5', Journal of Asian and African Studies’, Vol. 43(2): pp. 173-196.

McLarney, Ellen. 2009. 'The Burqa in Vogue: Fashioning Afghanistan', Journal of Middle East Women's Studies, Vol. 5, No. 1.

Mills, Margaret A. 1991. 'Gender and verbal performance style in Afghanistan', in Gender, genre, and power in South Asian expressive traditions. Ed. by Arjun Appadurai, Frank J. Korom, and Margaret A. Mills. Philadelphia : University of Pennsylvania Press.

Moghadam, Valentine M. 2004. 'A Tale of Two Countries: State, Society, and Gender Politics in Iran and Afghanistan’, The Muslim World, Volume 94, Issue 4.

Moghadam, Valentine M. 2002. 'Patriarchy, the Taleban, and politics of public space in Afghanistan’, Women's Studies International Forum, Volume 25, Issue 1.

Moghadam, V. M. 1993. 'Patriarchy and the Politics of Gender in Modernizing Societies: Iran, Pakistan and Afghanistan’, South Asia Bulletin, Vol. 13, No. 1-2.

Moghadam, Valentine M. 1993. 'Women and social change in Afghanistan', in Modernizing women: gender and social change in the Middle East. Boulder; London : L. Rienner, pp. 207-248.

Moghadam, Valentine M. 1992. 'Fundamentalism and the Woman Question in Afghanistan', in Fundamentalism in Comparative Perspective. Edited by Lawrence Kaplan. University of Massachusetts Press.

Nadir, Baser and Saghar Wafa. 2005. 'Field Notes and Observations on Gender and Decision-making in Kabul City’, AREU. Download PDF.

Nemat, Orzala Ashraf. 2011. 'Afghan Women at the Crossroads: Agents of Peace - Or Its Victims?’ Century Foundation Report. Download PDF.

Olesen, Asta. 1982. 'Marriage norms and practices in a rural community in North Afghanistan’, Folk, Vol. 24, pp. 111-141. 
Omidian, Patricia A. 1994. 'Life Out of Context: Recording Afghan Refugees' Stories', in Restructuring Lives, Recapturing Meaning: Refugee Identity, Gender, and Culture Change. L. A. Camino and R. M. Krulfeld, eds. Basel: Gordon and Breach Publishers.

Pourzand, Niloufar. 1999. 'The problematic of female education, ethnicity and national identity in Afghanistan', Social Analysis, Vol. 43, No 1, pp. 73-82.

Proctor, Celestine. 2005. 'Lessons from Approaches to Increasing Women's Participation in Development: Workshop Summary’, AREU. Download PDF.

Rahimi, Wali M. 1991. 'Status of Women: Afghanistan', RUSHAPS Series on Monographs and Occasional papers, UNESCO. Download PDF.

Raj, Anita, Charlemagne S. Gomez and Jay G. Silverman. 2011. 'Multisectorial Afghan Perspectives on Girl Child Marriage: Foundations for Change Do Exist in Afghanistan', Violence Against Women, Vol. 20, No. 10.

Raj, Anita, et al. 2008. 'Driven to a Fiery Death - The Tragedy of Self-Immolation in Afghanistan', New England Journal of Medicine, Vol. 358, No. 21.

Renner, Walter and Ingrid Salem. 2009. 'Post-Traumatic Stress in Asylum Seekers and Refugees From Chechnya, Afghanistan, and West Africa: Gender Differences in Symptomatology', International Journal of Social Psychiatry, 55(2).

Rights and Democracy. 2011. ‘A woman’s place: perspectives on Afghanistan’s evolving legal framework.’ Download PDF.

Riphenburg, Carol J. 2003. 'Gender relations and development in a weak state: the rebuilding of Afghanistan’, Central Asian Survey, 22(2), pp. 187 - 207.

Rostami-Povey, Elaheh. 2007. 'Gender, agency and identity, the case of Afghan women in Afghanistan, Pakistan and Iran’, Journal of Development Studies, Vol. 43, No. 2.

Rostami-Povey, Elaheh. 2007. 'Afghan Refugees in Iran, Pakistan, the U.K. and the U.S. and Life after Return: A Comparative Gender Analysis’, Iranian Studies, Vol. 40, No. 2.

Schmeidl, Susanne. 2009. 'The ‘Undoing of Gender Inequalities’ in Traditional Societies - The Example of Post-Conflict Afghanistan’, in Christine Eifler und Ruth Seifert (eds.) Gender Dynamics and Post-Conflict Reconstruction. Peter Lang Verlag.

Schneider, Irene. 2007. 'Recent Developments in Afghan Family Law: Research Aspects’, Asien, 104 (July 2007), pp. 106-118. Download PDF.

Schneider, Irene. 2005. 'The Position of Woman in the Islamic and Afghan Judiciary', in The Shari'a in the Constitutions of Afghanistan, Iran and Egypt: Implications for Private Law. Edited by Nadjma Yassari. Tubingen: Mohr Siebeck. 
Senate of Canada. 2010. 'Training in Afghanistan: Include Women', Standing Senate Committee on Human Rights. Download PDF.

Sengupta, Ami, et al. 2007. 'A Gender Analysis of an ICT Initiative in Afghanistan', The International Communication Gazette, Vol. 69(4): pp. 335-353.

Shalinsky, Audrey C. 1993. 'Women’s Role in the Afghanistan Jihad', International Journal of Middle Eastern Studies 25(4): 661-675.

Shalinsky, Audrey C. 1989. 'Talking about marriage: fate and choice in the social discourse of traditional Northern Afghanistan', Anthropos, Bd. 84, p. 133-140.

Shalinsky, Audrey C. 1986. 'Reason, Desire, and Sexuality: The Meaning of Gender in Northern Afghanistan’, Ethos, Vol. 14, No. 4, pp. 323-343.

Shepherd, Laura J. 2006. 'Veiled References: Constructions of gender in the Bush administration discourse on the attacks on Afghanistan post-9/11', International Feminist Journal of Politics, Volume 8, Number 3: pages 19-41 (March 2006).

Shin S. et al. 2009. 'Depression and PTSD in Pashtun Women in Kandahar, Afghanistan', Asian Nursing Research, Vol. 3, Issue 2.

SIGAR. 2009. 'Barriers to Greater Participation by Women in Afghan Elections', Special Inspector General for Afghanistan Reconstruction. Download PDF.

Smith, Deborah J. with Shelly Manalan. 2009. 'Community-Based Dispute Resolution Processes in Bamiyan Province', AREU. Download PDF.

Smith, Deborah J. and Jay Lamey. 2009. ‘A Holistic Justice System for Afghanistan’, AREU. Download PDF.

Smith, Deborah J. 2009. 'Community-Based Dispute Resolution Processes in Nangarhar Province’, AREU. Download PDF.

Smith , Deborah J. 2009. Decisions, Desires and Diversity: Marriage Practices in Afghanistan', AREU. Download PDF.

Smith, Deborah J. 2008. 'Love, Fear and Discipline: Everyday Violence Toward Children in Afghan Families’, AREU (February 2008). Download PDF.

Spears, Evelyn. 2005. 'Race, Justice, and War (Afghanistan-ethnic groups)', Peace and Freedom, (March 2005).

Stabil, Carol A., Deepa Kumar. 2005. 'Unveiling Imperialism: Media, Gender and the War on Afghanistan’, Media, Culture \& Society, Vol. 27, No. 5, pages 765-782. 
Tapper, N. 1982. 'Marriage preferences and ethnic relations among Durrani Pashtuns of Afghan Turkestan’, Folk, Vol 24, 1982, pp 157-177.

Tapper, Nancy. 1984. 'Causes and Consequences of the Abolition of Brideprice in Afghanistan', in Revolutions \& Rebellions in Afghanistan: Anthropological Perspective. M. N. Shahrani and R. L. Canfield. Berkeley: Institute of International Studies.

Tapper, Nancy. 1983. 'Acculturation in Afghan Turkistan: Pashtun and Uzbek women', Asian Affairs, Volume 14, Issue 1 February 1983 , pages 35 - 44.

Tavakolian, B. 1984. 'Women and socioeconomic change among Sheikhanzai nomads of western Afghanistan’, The Middle East Journal, Vol 38, No 3, pp 433-453;

Turner, Helen. 2006. 'Literature Review: Afghanistan Women's Health Crisis, Health Service Delivery, and Ethical Issues for International Aid', Health Care for Women International, Volume 27, Number 8: pages 748-759. (September 2006).

UNAMA. 2010. 'Harmful Traditional Practices and Implementation of the Law on Elimination of Violence against Women in Afghanistan', United Nations Assistance Mission in Afghanistan. Download PDF.

UNAMA. 2009. 'Silence is Violence: End the Abuse of Women in Afghanistan', United Nations Assistance Mission in Afghanistan. Download PDF.

UNIFEM. 2006. 'Uncounted and discounted: a secondary data research project on violence against women in Afghanistan’, UNIFEM. Download PDF.

UNIFEM. 2005. 'Child and Forced Marriage, Afghanistan’, UNIFEM. Download PDF.

Verdirame, Guglielmo. 2001. 'Testing the Effectiveness of International Norms: UN Humanitarian Assistance and Sexual Apartheid in Afghanistan’, Human Rights Quarterly, Vol. 23. Link to PDF.

Wakefield, Shawna. 2005. 'Field Notes and Observations on Gender and Decisionmaking in Herat', AREU. Download PDF.

Wakefield, Shawna. 2005. 'Gender and Local Level Decision Making: Findings from a Case Study in Samangan’, AREU. Download PDF.

Wakefield, Shawna and Brandy Bauer. 2005. 'A Place at the Table: Afghan Women, Men and Decision-Making Authority’, AREU. Download PDF.

Wakefield, Shawna. 2004. 'Gender and Local Level Decision Making: Findings from a Case Study in Mazar-e Sharif', AREU. Download PDF. 
Wakefield, Shawna. 2004. 'Gender and Local Level Decision Making: Findings from a Case Study in Panjao', AREU. Download PDF.

Wakefield, Shawna. 2004. 'Gender and Local Level Decision Making: Findings from a Case Study in Samangan’, AREU. Download PDF.

Wali, Sima. 2004. ‘Afghan Women: Reconstruction, Civil Society and U.S. Policy’, in Political Transition in Afghanistan: The State, Islam and Civil Society. Asia Program Special Report, No 122. Download PDF.

Womankind Worldwide. 2008. 'Taking Stock Update: Afghan Women and Girls Seven Years On’, Womankind Worldwide. February 2008. Download PDF.

Wordsworth, Anna. 2007. 'A Matter of Interests: Gender and the Politics of Presence in Afghanistan’s Wolesi Jirga’, AREU. Download PDF.

Yacoobi, Sakena. 2008. 'Building a Better Afghanistan through Female Education', in Girl's Education in the $21^{\text {st }}$ Century: Gender Equality, Empowerment and Growth. Edited by Mercy Tembon and Lucia Fort. World Bank Publications.

Yassari, Nadjma. 2005. 'Legal Pluralism and Family Law: An Assessment of the Current Situation in Afghanistan', in The Shari'a in the Constitutions of Afghanistan, Iran and Egypt: Implications for Private Law. Nadjma Yassari (ed.). Tubingen: Mohr Siebeck.

Zahedi, Ashraf. 2007. 'Transnational Marriages, Gendered Citizenship, and the Dilemma of Iranian Women Married to Afghan Men’, Iranian Studies, Vol. 40, No. 2.

Zulfacar, Maliha. 2006. 'The Pendulum of Gender Politics in Afghanistan', Central Asian Survey, Volume 25, Number 1-2: pages 27-59. (March-June 2006).

\section{Theses and Dissertations}

Aaftaab, Naheed G. 2004. Developing educated Afghan women: a critical case study. Thesis (M.A.)--University of Washington.

Armstrong, Sally. 2001. Missing in access: a feminist critique of international documents that pertain to the human right of adolescent girls to access to health services and their impact on young women in Afghanistan and in Canada. Thesis (M.Sc.)--University of Toronto. Download PDF.

Burki-Liebl, Shireen. 2007. The Politics of State Intervention: State Policy and the Status of Women in Pakistan (1947-2006) and Afghanistan (1919-2006). PhD dissertation. Department of Political Science, University of Utah.

Cathcart, Susan. 2004. Rhetoric versus reality prospects for women's rights in posttaliban Afghanistan. Thesis (M.S.)--Virginia Polytechnic Institute. Download PDF. 
Fluri, Jennifer L. 2005. Beyond the burqa: the spatial politics of Afghanistan's revolutionary women. Thesis (Ph.D.)--Pennsylvania State University.

Gilmour, Erica M. 2007. A woman's work: exploring gender roles and agriculture in Charikar, Afghanistan. Thesis (M.A.)--Carleton University.

Hamill, Clare. 2002. A critical appraisal of international peacekeeping and the role of women in Afghanistan. Thesis (LL.M.)--Center for Civil and Human Rights, Notre Dame.

Hirji, Faiza. 2003. The woman behind the man: politicized portrayals of Afghan Muslim women in wartime. Thesis (M.A.)--Carleton University.

Kazemi-Trensch, Nosrat. 2003. Bildung von Mädchen und Berufsleben der Frauen in drei islamischen Ländern Afghanistan, Iran, Jordanien (ein Vergleich). Dissertation: Heidelberg, Universitat, Diss., 2003. Download PDF.

Krayer, Patrick Edwin. 2007. Gender in Pashtun and Pauline communities: Insights for development workers. Ph.D. dissertation, Fuller Theological Seminary, School of Intercultural Studies.

Pierce, Teresa "Tess." 2007. Women, weblogs, and war: Digital culture and gender performativity. Three case studies of online discourse by Muslim cyberconduits of Afghanistan, Iran, and Iraq. PhD Dissertation, Clark University.

Stewart, Chloé Elizabeth. 2006. "Liberation" through fetishism: the colonization of Afghan women by United States feminists. Thesis (M.A.)--San Francisco State University.

Zeleny, Beth Ann. 2000. Gendered space in Afghan refugee camps. PhD Dissertation, The Pennsylvania State University. 


\section{Military: Operations, Civil-Military Relations, PRTs and COIN}

\section{Books}

Bahmanyar, Mir and Ian Palmer. 2004. Afghanistan Cave Complexes, 1979-2004:

Mountain Strongholds of the Mujahideen, Al Qaeda and the Taliban. Osprey Publishing.

Giustozzi, Antonio. 2008. Koran, Kalashnikov and Laptop: The Neo-Taliban Insurgency in Afghanistan. New York: Columbia University Press.

Grau, Lester W. (editor) 2003. The Bear Went Over the Mountain: Soviet Combat Tactics in Afghanistan. Routledge.

Gress, Michael A. and Lester W. Grau (eds), Russian General Staff. 2002. The SovietAfghan War: How a Superpower Fought and Lost. University Press of Kansas.

Horn, Burnd. 2010. No Lack of Courage: Operation Medusa, Afghanistan. Dundurn Press.

Jalali, Ahmed Ali and Lester W. Grau. 2002. Afghan Guerilla Warfare. Osprey.

Kaiser, Steve. 2009. Doorstep Diplomacy: The deployment and experiences of a Civil Affairs Team Leader in Afghanistan. Acacia Publishing.

Maloney, Sean M. 2009. Confronting the Chaos: A Rogue Military Historian Returns to Afghanistan. Naval Institute Press.

McMichael, Scott R. 1991. Stumbling Bear: Soviet Military Performance in Afghanistan, Brassey's, London.

Neville, Leigh. 2009. Special Operations Forces in Afghanistan: Afghanistan 2001-2007. Osprey publishing.

O’Ballance, Edgar. 1993. Afghan Wars 1839-1992: What the British Gave Up and the Soviet Union Lost. Brassey's, London, 1993.

Porter, Patrick. 2009. Military Orientalism: Eastern war Through Western Eyes. Hurst (UK), Columbia University Press (US).

Rietjens, S.J.H. 2008. Civil-Military Cooperation in Response to a Complex Emergency: Just Another Drill? Netherlands Defence Academy. 
Rothstein, H.S. 2006. Afghanistan and the Troubled Future of Unconventional Warfare. Monterey, CA: Naval Institute Press.

Shaw, Geoffrey D.T. 2009. A Military History of Afghanistan: Between the hammer and the Anvil. Praeger Security International Press.

Tamas, Andy. 2009. Warriors and Nation Builders: Development and the Military in Afghanistan. Kingston: Canadian Defence Academy Press. Download PDF.

Tanner, Stephen. 2002. Afghanistan: A Military History from Alexander the Great to the Fall of the Taliban. Cambridge, MA: Da Capo Press.

West, Bing. 2011. The Wrong War: Grit, Strategy, and the Way Out of Afghanistan. Random House.

Wright, Donald P. et al. 2010. A Different Kind of War: The United States Army in OPRATION ENDURING FREEDOM, October 2001 - September 2005. Fort Leavenworth, KS: Combat Studies Institute Press. Download PDF.

\section{Articles, Reports and Book Chapters}

Abbasi, Rizwana. 2008. 'Ethics of the war on terror - can the war in Afghanistan be won under the present rules of engagement?’, Paper at University of Leicester seminar. PDF.

Abbaszadeh, Nima, et al. 2008. 'Provincial Reconstruction Teams: Lessons and Recommendations,' Princeton University Woodrow Wilson School. Download PDF.

Adair, Jason T. 'Learning on the run: company level counter-insurgency in Afghanistan', Canadian Army Journal, Vol. 10, No. 4. Download PDF.

Afsar, Shahid, Chris Samples, and Thomas Wood. 2008. 'The Taliban: An Organizational Analysis’, Military Review, May-June 2008. Download PDF.

Ahmad, Irfan. 2009. Role of Airpower for Counterinsurgency in Afghanistan and FATA (Federally Administered Tribal Areas). NPS master's thesis. Download PDF.

Ali, Imtaz. 2008. 'Preparing the Mujahidin: The Taliban’s Military Field Manual', CTC Sentinel, Vol. 1, Issue 10. Download PDF.

Almantas Leika. 2007. 'Operational and Strategic Lessons Learned from Running a PRT', $2^{\text {nd }}$ Annual Baltic Conference on Defence (ABC/D). Download PDF.

Amend, Kurt. 2008. 'Counterinsurgency Principles for the Diplomat', Small Wars Journal. Download PDF. 
American Anthropological Association. 2009. 'Afghanistan: The Army’s Human Terrain System Proof of Concept Program’. Download PDF.

Armstrong, Bradley J. 2003. Rebuilding Afghanistan: counterinsurgency and reconstruction in Operation Enduring Freedom. NPS Thesis (M.S). Download PDF.

ARRC. 2009. ‘My Cousin’s Enemy is My Friend: A Study of Pashtun “Tribes” in Afghanistan', Afghanistan Research Reachback Center White Paper. TRADOC G2 Human Terrain System. United States Army. Fort Leavenworth, KS. Download PDF

Azarbaijani-Moghaddam, Sippi et al. 2008. 'Afghan Hearts, Afghan Minds: Exploring Afghan perceptions of civil-military relations', ENNA/BAAG. Download PDF.

BAAG/ENNA. 2008. 'Aid and Civil-Military Relations in Afghanistan BAAG and ENNA policy briefing. Download PDF.

Barno, David W. 2007. 'Fighting “The Other War:” Counterinsurgency Strategy in Afghanistan, 2003-2005’, Military Review, Sept-Oct 2007. Download PDF.

Barrett, Richard. 2010. 'Boldness Be My Friend: Why the High Risk Plan is Often the Safest (and the Most Successful)', Australian Army Journal, Vol. VII, No. 3. PDF.

Basso, John A. 2004 America's last battles: organizing brigades to win the peace 14 lessons from East Timor, Afghanistan, and Iraq. U.S. Army CGSC. Download PDF.

Bebber, Robert J. 2009. 'Developing an IO Environmental Assessment in Khost Province: Information Operations at PRT Khost in 2008', Small Wars Journal, February 2009. PDF.

Bebber, Robert J. 2008. 'The Role of Provincial Reconstruction Teams in Counterinsurgency Operations: Khost Province, Afghanistan’, Small Wars Journal, November 2008. PDF.

Bell, Kevin. 2009. 'Pulling Teeth: An Infantry Platoon Leader's Perspective on a Year in Afghanistan’, Army Magazine, May 2009.

Benini, Aldo A. and L. H. Moulton. 2004. 'Civilian Victims in an Asymmetrical Conflict: Operation Enduring Freedom, Afghanistan', Journal of Peace Research, Vol. 41, No. 4.

Betz, David. 2008. 'The virtual dimension of contemporary insurgency', Small Wars \& Insurgencies, Vol. 19, No. 4.

Biddle, Stephen. 2003. 'Afghanistan and the Future of Warfare', Foreign Affairs, Vol. 82, No. 2. 
Biddle, Stephen. 2002. 'Afghanistan and the Future of Warfare: Implications for Army and Defense Policy’, U.S. Army War College Strategic Studies Institute. PDF.

Bird, Sheila. 2009. 'IEDs and Military Fatalities in Iraq and Afghanistan', The RUSI Journal, Volume 154, Issue 4.

Blank, Stephen J. 1993. 'Afghanistan and Beyond: Reflections on the Future of Warfare', Strategic Studies Institute. Download PDF.

Blatt, Darren J., Eric Long, Brian Mulhern and Michael Ploskunak. 2009. 'Tribal Engagement in Afghanistan', Special Warfare, Volume 22, Issue 1. Download PDF.

Blatt, Darin J. and Glenn Bollinger. 2009. 'Out of the Box: Training Combat Adviser for Afghanistan’, Special Warfare, Vol. 22, No. 3. Download PDF.

Bluesteen, Christopher. 2009. 'Combat Advising: Three Challenges We Must Overcome to Succeed in Afghanistan’, Small Wars Journal, April. Download PDF.

Bolduc, C. and Captain J. Vachon. 2010. 'Making Strides at the Heart of the Insurgency', Canadian Army Journal, Volume 13, No. 2. Download PDF.

Bolduc, Donald C. 2009. 'Organizing Counterinsurgency Operations in Afghanistan', Small Wars Journal, August 2009. Download PDF.

Borders, Robert. 2004. 'Provincial Reconstruction Teams in Afghanistan: a model for post-conflict reconstruction and development', Journal of Development and Social transformation, Vol. 1 (November 2004).

Booth, Brad. 2008. 'Winning in Afghanistan: a NATO Operational Design', US Army War College. Download PDF.

Bowen, D. 2010. 'Combatants in Afghanistan: What's in a Name?', Canadian Army Journal, Volume 13, No. 2. Download PDF.

Bowen, Dominic. 2010. 'Combatants in Afghanistan: What's in a Name?', Australian Army Journal, Vol. VII, No. 3. Download PDF.

Brandt, Ben. 2011. 'The Taliban’s Conduct of Intelligence and Counterintelligence', CTC Sentinel, Vol. 4, No. 6. Download PDF.

Bue, Kara L. and John A. Gastright. 2009. 'The Debate over Taliban Reconciliation', CTC Sentinel, Vol. 2, Issue 2. Download PDF.

Bumgarner, Amy S. 2009. Learning from Our Past: How a Vietnam-era Pacification Program Can Help Us Win in Afghanistan. NPS master's thesis. Download PDF. 
Bristol, N. 2006. 'Military Incursions into Aid Work Anger Humanitarian Groups', The Lancet, Volume 367, Issue 9508 (February 4, 2006): pages 384-386.

Brouns, T. 2009. 'Exploiting Insurgent Violence', Military Review, July-August. PDF.

Cadieu, Trevor. 2008. 'Canadian Armour in Afghanistan', Canadian Army Journal, Vol. 10.4 (Winter 2008), pp. 5-25. Download PDF.

Campbell, Jason et al. 2009. 'Assessing Counterinsurgency and Stabilization Missions', Foreign Policy at Brookings Policy Paper No. 14. Download PDF.

Cassidy, Robert M. 2003. 'Russia in Afghanistan and Chechnya: military strategic culture and the paradoxes of asymmetric conflict', Strategic Studies Institute. Download PDF.

Cathell, John H. 2009. 'Human Geography in the Afghanistan - Pakistan Region: Undermining the Taliban Using Traditional Pashtun Social Structures', Naval War College Report. Download PDF.

CENTCOM Public Affairs. 2009. 'US Central Command Investigation into Civilian Casualties in Farah Province.’ Download PDF.

Cerami, J. and J. Boggs. 2007. 'The Interagency and Counterinsurgency Warfare: Stability, Security, Transition, and Reconstruction Roles', SIS. Download PDF.

Chandrasekaran, Rajiv. 2011. 'Is NATO’s Counterinsurgency Strategy Working in Afghanistan? A Case Study’, Centre for International Policy Studies. Download PDF.

Chin, Warren. 2010. 'Colonial Warfare in a Post-Colonial State: British Military Operations in Helmand Province, Afghanistan’, Defence Studies, Vol. 10, No. 1.

Chin, Warren. 2007. 'British Counter-Insurgency in Afghanistan', Defense \& Security Analysis, Vol. 23, No. 2, pp. 201-225.

Choharis, Peter Charles and James A. Gavrilis. 2010. 'Counterinsurgency 3.0’, Parameters, Spring 2010. Download PDF.

Clark, Kate. 2011. 'The Takhar attack: Targeted killings and the parallel worlds of US intelligence and Afghanistan’, Afghanistan Analysts Network. Download PDF.

Clukey, David S. 2010. 'A District Approach in Afghanistan?', Small Wars Journal, April. Download PDF.

Coffey, Luke. 2009. 'Detainee Operations in Counterinsurgency Operations Lessons from Afghanistan 2005-2006’, Small Wars Journal, September 2009. PDF.

Collins, J. 2009. 'Afghanistan: The Path to Victory’, Joint Force Quarterly, 54. PDF. 
Collins, J. 2007. 'The Perils of Planning: Lessons from Afghanistan and Iraq', in The Interagency and Counterinsurgency Warfare: Stability, Security, Transition, and Reconstruction Roles. Ed. by J. Cerami and J. Boggs. Download PDF.

Connable, Ben. 2009. 'All our eggs in one basket: how the Human Terrain System is undermining sustainable military cultural competence’, Military Review, Mar.-Apr. PDF.

Cordesman, A. 2009. 'The Air War in Afghanistan: The Broader Issue’, CSIS. PDF.

Cordesman, Anthony H. 2009. “"Shape, Clear, Hold, and Build:” The Uncertain Metrics of the Afghan War', CSIS. Download PDF.

Corn, Tony. 2009. 'Toward a Kilcullen-Biden Plan? Bounding Counterinsurgency in Afghanistan’, Small Wars Journal, October 2009. Download PDF.

Cornish, S. and M. Glad. 2008. 'Civil-military relations: no room for humanitarianism in comprehensive approaches’, CARE International. Download PDF.

Cornish, Stephen and Marit Glad. 2009. 'Civil-Military Relations: No Room for Humanitarianism in Comprehensive Approaches’, Norwegian Atlantic Committee. PDF.

Cornish, P. 2007. 'No room for humanitarianism in 3D policies: have forcible humanitarian interventions and integrated approaches lost their way?', Centre for Military and Strategic Studies, University of Calgary. Download PDF.

Cornish, S. and M. Glad. 2008. 'Civil-military relations: no room for humanitarianism in comprehensive approaches’, CARE International. Download PDF.

Coss, Michael A. 2006. 'Operation Mountain Lion: CJTF-76 in Afghanistan Spring 2006,’ Military Review, January-February 2008. Download PDF.

Cox, David. 1991. Soviet counterinsurgency doctrine and strategy in Afghanistan: an operational assessment of the campaign. Thesis (Ph. D.)--George Washington University.

Cox, Joseph L. 2006. 'Information Operations in Operations Enduring Freedom and Iraqi Freedom: What Went Wrong?’, SAMS Monograph. Download PDF.

Crow, Trampes C. 2010. 'Unfocused Energy: A Strategic Approach to U.S.

Communications in Afghanistan’, SAMS Monograph. Link to PDF.

Crumpton, Henry. 2005. 'Intelligence and War: Afghanistan 2001-2', in Transforming U.S. Intelligence. Edited by E. Sims and Burton Gelber. Washington: Georgetown University Press. 
Dadkhah, Lara M. 2008. 'Close Air Support and Civilian Casualties in Afghanistan', Small Wars Journal, December 2008. Download PDF.

Darling, Paul. 2011. 'The Five Fights of the Surkhagan and the Future of ISAF', Military Review, July-August. Download PDF.

Davis, Mark G. 2004. Operation Anaconda command and confusion in Joint Warfare. Dissertation thesis--School of Advanced Air and Space Studies, Air University.

Dehnert, P.A. 2010. 'Size Matters: Turning to Small Teams to Succeed at Counterinsurgency’, Australian Army Journal, Vol. VII, No. 3. Download PDF.

Depart. of Defense. 2009. 'Afghanistan Security Forces Fund Phase III-U.S. Army Corps of Engineers Real Property Accountability’, Inspector General Dept. of Defense. PDF.

Department of Defense. 2008. 'Assessment of Arms, Ammunition, and Explosives Control and Accountability; Security Assistance; and Sustainment for the Afghan National Security Forces', US Department of Defense. Downoad PDF.

Department of Defense. 2007. 'Strategic Communication Plan for Afghanistan.’ PDF.

Dessaso, Christopher D. 2010. 'Toward Development of Afghanistan National Stability: Analyses in Historical, Military, and Cultural Contexts’, SAMS Monograph. Link to PDF.

Dietz, A. Steven. 2011. 'Countering the effects of IED systems in Afghanistan: an integral approach’, Small Wars \& Insurgencies, Vol. 22, No. 2.

Dimitriu, George and Beatrice de Graaf. 2010. 'The Dutch COIN approach: three years in Uruzgan, 2006-2009’, Small Wars \& Insurgencies, Vol. 21, No. 3.

Dobbins, James. 2009. 'Counterinsurgency in Afghanistan', Testimony presented before the Senate Armed Services Committee on February 26, 2009. Download PDF.

Donahue, Patrick and Michael Fenzel. 2008. 'Combating a Modern Insurgency: Combined Task Force Devil in Afghanistan’, Military Review, March-April 2008. PDF.

Doohovskoy, Andrei A. 2009. Soviet Counterinsurgency in the Soviet Afghan War Revisited: Analyzing the Effective Aspects of the Counterinsurgency Effort. MA thesis, Harvard University.

Downey, Robert A. 2008. 'How Should the U.S. Execute a Surge in Afghanistan?', Small Wars Journal, November 2008. Download PDF.

Dressler, Jeffrey. 2009. 'Securing Helmand: Understanding and Responding to the Enemy’, Institute for the Study of War. Afghanistan Report \#2. Download PDF. 
Drolet, John D. 'Provincial Reconstruction Teams: Afghanistan vs. Iraq - Should We Have a Standard Model?’, USAWC Strategy Research Project. PDF.

Dubik, Kames M. 2009. ‘Accelerating Combat Power in Afghanistan’, Best Practices in Counterinsurgency, Report \#2. Download PDF.

DuPee, Matthew C. 2008. 'Badghis Province: examining the Taliban's Northwestern Campaign', The Culture and Conflict Review, Vol. 2, No. 5. Download PDF.

Dyke, John R. and John R. Crisafulli. 2006. 'Unconventional Counter-Insurgency in Afghanistan’, Thesis, Naval Postgraduate School. Monterey, CA. Download PDF.

Dziedzic, Michael J. and Michael K. Seidl. 2005. 'Provincial reconstruction Teams: Military Relations with International and Nongovernmental Organizations in Afghanistan', USIP Special Report, Number 147. Download PDF.

Edwards, David B. 2010. 'Counterinsurgency as a Cultural System', Small Wars Journal, December 2010. Download PDF.

Egnell, Robert. 2010. 'Winning 'Hearts and Minds'? A Critical Analysis of CounterInsurgency Operations in Afghanistan', Civil Wars, Vol. 12, No. 3.

Egnell, Robert. 2011. 'Lessons from Helmand, Afghanistan: what now for British counterinsurgency?’, International Affairs, Volume 87, Issue 2.

Ehrhart, Thomas P. 2009. 'Increasing Small Arms Lethality in Afghanistan: Taking Back the Infantry Half-Kilometer’, SAMS Monograph. Link to PDF.

Eikenberry, Karl W. and Stanley H. McChrystal. 2009. 'United States Government Integrated Civilian - Military Campaign Plan for Support to Afghanistan’, U.S. Chief of Mission and the Commander of U.S. Forces-Afghanistan. Download PDF.

Eronen, Oskari. 2008. 'PRT Models in Afghanistan: Approaches to Civil-Military Integration’, CMC Finland Civilian Crisis Management Studies, Vol. 1, No. 5. PDF.

Erwin, Michael. 2008. 'Key Factors for the Recent Growth of the Afghan Insurgency', CTC Sentinel, Vol. 1, Issue 9. Download PDF.

Exum, Andrew W. et al. 2009. 'Triage: The Next Twelve Months in Afghanistan and Pakistan’, CNAS Report. Download PDF.

Fairweather, Clive. 2009. 'Afghanistan: Statistics of War; Helicopters, bombs and strategies’, Significance, Volume 6, Issue 4.

Farrell, Theo and Stuart Gordon. 2009. 'COIN Machine: The British Military in Afghanistan', Orbis, Vol. 53, Issue 4. 
Fenzel, Michael. 2010. 'The Maneuver Company in Afghanistan: Establishing Counterinsurgency Priorities at the District Level', Military Review, March-April. Download PDF.

Ferris, John. 2006. 'Invading Afghanistan, 1838-2006: Politics and Pacification', Journal of Military and Strategic Studies, Vol. 9, Issue 1. Download PDF.

Fick, Nathaniel C. and John A. Nagl. 2009. 'Counterinsurgency Field Manual:

Afghanistan Edition’, Foreign Policy, Jan./Feb. Read online.

Finel, Bernard I. 2010. 'Planning a Military Campaign to Support Negotiations in Afghanistan’, Small Wars Journal, Vol. 6, No. 10. Download PDF.

Fitzgerald, Ronald J. 2010. 'The Canadian Strategic Advisory Team to Afghanistan: A Possible Model for a Multinational Whole of Government Approach to Defeating an Insurgency', SAMS Monograph. Link to PDF.

Flynn, Michael T. 2010. 'Fixing Intel: A Blueprint for Making Intelligence Relevant in Afghanistan’, Center for a New American Security. Download PDF.

Foust, Joshua. 2009. 'What Really Happened in the Tagab Valley? A Response to Second Lieutenant James Parker’, Small Wars Journal, September 2009. Download PDF.

Foxley, Tim. 2007. 'The Taliban's propaganda activities: how well is the Afghan insurgency communicating and what is it saying?', SIPRI Project Paper. Download PDF.

Fraser, Andrew. 2009 'Deadly Ends: Canada, NATO and Suicide as a Weapon of War in Modern Afghanistan’, Canadian Army Journal, Vol. 12, No. 2. Download PDF.

French, Nils N. 2008. 'The Sarposa Prison Break', Canadian Army Journal, Vol. 11, No. 2. Download PDF.

French, Nils N. 2008. 'Learning from the Seven Soviet Wars: Lessons for Canada in Afghanistan’, Canadian Army Journal, Vol. 10.4, pp. 36-47. Download PDF.

Frerks, G. et al. 2006. 'Principles and pragmatism: civil-military action in Afghanistan and Liberia', Cordaid. Download PDF.

Frewen, John. 2008. 'Contested Nation-Building: The Challenge of Countering Insurgency in Afghanistan in 2007’, Australian Army Journal, Vol. 5, Number 1. PDF.

Galli, Thomas L. 2008. 'The Narcotics Counterinsurgency Dilemma', SAMS Monograph. Download PDF. 
Gauster, Markus. 2008. 'Provincial Reconstruction Teams in Afghanistan', Marshall

European Center for Security Studies. Occasional Paper \#16 (January 2008). PDF.

Gauthier, Michel. 2009. 'Canadian Forces in Afghanistan - Then, Now and Beyond', On Track, Vol. 14, No. 1.

GAO. 2009. 'Military Operations: Actions Needed to Improve Oversight and Interagency Coordination for the Commander's Emergency Response Program in Afghanistan', Government Accountability Office. Download PDF.

Gentile, Gian P. 2009. 'Gaining the Initiative in Afghanistan', Small Wars Journal, September 2009. Download PDF.

Gezari, Vanessa. 2010. 'Rough Terrain: The Human Terrain System in Afghanistan', in The Afghanistan-Pakistan Theater: Militant Islam, Security \& Stability. Edited by Edited by Daveed Gartenstein-Ross \& Clifford D. May. Washington: FDD Press. PDF.

Gibbs, David. 1986. 'The Peasant as Counter-Revolutionary: The Rural Origins of the Afghan Insurgency', Studies in Comparative International Development, Vol. 21(1).

Gibson, John G. 2008. 'After Action Report: Nuanced Diplomacy in Zerok, Afghanistan', CTC Sentinel, Vol 1, Issue 8. Download PDF.

Glatz, Rainer. 2011. 'ISAF lessons learned: A German perspective', PRISM 2, No. 2 Download PDF.

Glenn, Russell W. and S. Jamie Gayton. 2008. 'Intelligence Operations and Metrics in Iraq and Afghanistan', Fourth in a Series of Joint Urban Operations and Counterinsurgency Studies. RAND. Download PDF.

Golinghorst, Kevin R. 2010. ‘Mapping the Human Terrain in Afghanistan’, SAMS Monograph. Link to PDF.

Grau, Lester. 2009. 'The Soviet-Afghan War: A Superpower Mired in the Mountains', in Conflict and Insurgency in the Contemporary Middle East. Barry Rubin (ed). Routledge.

Grau, Lester W. 2007. 'Breaking Contact Without Leaving Chaos: The Soviet Withdrawal from Afghanistan’, The Journal of Slavic Military Studies, Vol. 20(2).

Grau, Lester W. 1999. 'The Soviet-Afghan War: A Superpower Mired In The Mountains', Journal of Slavic Military Studies, Vol. 17, Issue 1.

Grasso, Valerie Bailey. 2009. 'Defense Logistical Support Contracts in Iraq and Afghanistan: Issues for Congress’, CRS Report for Congress. Download PDF. 
Green, Daniel R. 2011. 'Defeating the Taliban's Shadow Government: Winning the Population through Synchronised Governance, Development and Security Efforts', Australian Army Journal, Volume VIII, Number 1. Download PDF.

Green, Dan. 2009. 'Going Tribal: Enlisting Afghanistan’s Tribes’, Small Wars Journal, August 2009. Download PDF.

Griffin, Stuart. 2011. 'Iraq, Afghanistan and the future of British military doctrine: from counterinsurgency to Stabilization’, International Affairs, Vol. 87, Issue 2.

Groh, Ty L. 2006. 'Ungoverned Spaces: the Challenges of Governing Tribal Societies', Naval Postgraduate School Thesis. Monterey, California (June 2006). Download PDF.

Hack, Karl. 2009. 'Extracting counterinsurgency lessons: The Malayan Emergency and Afghanistan’, History on Rusi.org. Download PDF.

Hagstrøm, Mathias. 2009. 'The Challenges of IED Awareness and MRE in Afghanistan', Journal of ERW and Mine Action, Vol. 13, No. 1. Read online.

Hall, Michael T. and Stanley McChrystal. 2009. 'COMISAF/USFOR-A

Counterinsurgency (COIN) Training Guidance’, NATO/ISAF. Download PDF.

Hallet, Michael. 2008. 'New Potentials for Provincial Reconstruction Teams', Small Wars Journal. Download PDF.

Hammes, T.X. et al. 2009. 'Afghanistan: Connecting Assumptions and Strategy', Proceedings, November 2009.

Hammidov, Bakhtiyorjon U. 2004. 'The Fall of the Taliban and its Recovery as an Insurgent Movement in Afghanistan', U.S. Army Command and General Staff College Master's thesis. Download PDF.

Hastert, Paul L. 2005 'Operation Anaconda: Perception Meets Reality in the Hills of Afghanistan’, Studies in Conflict and Terrorism, Vol. 28, No. 1.

Hastings, Michael D. 2005. Integration of conventional forces and special operations forces. Thesis (MMAS)—U.S. Command and General Staff College (CGSC). PDF.

Håvoll, Harald. 2008. 'COIN Revisited: Lessons of the classical literature on counterinsurgery and its applicability to the Afghan hybrid insurgency', NUPI Report, Security in Practice No.13. Download PDF.

Hawkins, Jon. 2010. 'Assessing Afghanistan against Aden and Oman: A Euphemism for Capitulation or the Seeds of Success?', Australian Army Journal, Volume VII, Number 1. Download PDF. 
Hernandorena, Carlos. 2007. 'U.S. Provincial Reconstruction Teams in Afghanistan, 2003-2006: Obstacles to Interagency Cooperation’, pp. 121-170 in The Interagency and Counterinsurgency Warfare. Edited by Joseph R Cerami and Jay W. Boggs. PDF.

Hoadley, Stephen. 2011. 'The New Zealand PRT Experience in Bamyan Province: Assessing Political Legitimacy and Operational Achievements', in Statebuilding in Afghanistan: Multinational Contributions to Reconstruction. Edited by Nik Hynek and Péter Marton. Routledge.

Hochwart, Michael A. 2009. 'The Provincial Reconstruction Teams in Afghanistan: A Model for Future Nation Building Operations’, SAMS Monograph. Download PDF.

Hollanda, Kenneth. 2010. 'The Canadian Provincial Reconstruction Team: The Arm of Development in Kandahar Province', American Review of Canadian Studies, Volume 40, Issue 2.

Holt, Ronald L. 2009. ‘Afghan Village Militia: A People-Centric Strategy to Win’, Small Wars Journal, September 2009. Download PDF.

Hope, Ian. 2008. 'Unity of Command in Afghanistan: A Forsaken Principle of War', Us Army War College. Download PDF.

Hughes, Geraint. 2008. 'The Soviet-Afghan War, 1978-1989: An Overview', Defence Studies, Vol. 8, No. 3.

Humayoon, Haseeb. 2007. 'The Iraqization of Insurgency in Afghanistan', Center for Conflict and Peace Studies, Kabul.

Hussain, Raja G. 2008. Badal, A Culture of Revenge: The Impact of Collateral Damage on Taliban Insurgency. Naval Postgraduate School Master's Thesis. Download PDF.

Jakobsen, Peter Viggo. 2005. 'PRTs in Afghanistan: successful but not sufficient', DIIS Report 2005: 6. Danish Institute for International Studies. Download PDF.

Jansen, C.R. 2010. 'The Kandahar Light Logistics Platoon', Canadian Army Journal, Vol. 12, No. 3. Download PDF.

Jebnoun, Noureddine. 2008. 'The Denial of Failure in Afghanistan', Small Wars Journal, Download PDF.

Jockel, Joseph and Sokolsky, Joel. 2008. 'Canada and the war in Afghanistan: NATO's odd man out steps forward', Journal of Transatlantic Studies, Vol. 6, No. 1, pp. 100-115.

Johnson, Thomas H. and M. Chris Mason. 2009 'Afghanistan and the Vietnam Template', Military Review, November-December 2009. Download PDF. 
Johnson, Thomas H. 2007. 'The Taliban Insurgency and an Analysis of Shabnamah (Night Letters)', Small Wars and Insurgencies, Vol. 18, No. 3.

Johnson, Thomas H. and M. Chris Mason. 2007. 'Understanding the Taliban and Insurgency in Afghanistan,' Orbis, Winter 2007.

Jones, Seth G. 2008. ‘Counterinsurgency in Afghanistan’, RAND Report. PDF.

Jones, Seth G. 2007. 'The State of the Afghan Insurgency', Testimony for the Canadian Senate National Security and Defence Committee . RAND. December 2007. PDF.

Kan, Paul Rexton. 2011. 'Making a Sandwich in Afghanistan: How to Assess a Strategic Withdrawal from a Protracted Irregular War', Small Wars Journal, Vol. 7 No. 2. PDF.

Kemp, Robert E. 2011. 'Local Governance and COIN in Eastern Afghanistan 2004-2008', Military Review, January-February. Download PDF.

Kemp, Robert. 2010. 'Counterinsurgency in Nangarhar Province, Eastern Afghanistan, 2004-2008’, Military Review, November-December. Download PDF.

Kerry, John. 2009. 'Tora Bora Revisited: How we failed to get Bin Laden and why it matters today', A Report to the Committee on Foreign Relations, US Senate. PDF.

Khalil, Lydia. 2009. 'Iraq the Model? How Applying Lessons from our Successes and Failures in Iraq Can Shape a Winning Strategy in Afghanistan', Small Wars Journal, October 2009. Download PDF.

Khan, Mehar Omar. 2009. ‘Afghanistan: Seven Fundamental Questions', Small Wars Journal, November 2009. Download PDF.

Khan, M.O. 2009. 'Don't Try to Arrest the Sea: An Alternative Approach for Afghanistan’, Small Wars Journal, October 2009. Download PDF.

Kilcullen, David. 2009. 'Taliban and Counter-Insurgency in Kunar', in Antonio Giustozzi (ed.) Decoding the New Taliban: Insights from the Afghan Field. Hurst/Columbia.

King, Anthony. 2011. 'Operation Herrick: The British Campaign in Helmand', in Statebuilding in Afghanistan: Multinational Contributions to Reconstruction. Edited by Nik Hynek and Péter Marton. Routledge.

Kinnunen, Eero and Lester W. Grau. 2011. 'Two Tours in Afghanistan: Twenty Years and Two Armies Apart', Military Review, May-June. Download PDF.

Kolenda, Christopher. 2010. 'Winning Afghanistan at the Community Level', Joint Forces Quarterly, Issue 56. Download PDF. 
Kotkin, Jeremy. 'Is the War in Afghanistan in the Interests of the United States and its Allies?’, Small Wars Journal, August 2009. Download PDF.

Kraft, James E. 2008. Afghanistan: A War That Can Only Be Won via the Concentration of United States Elements of National Power. National Defense University, Master's thesis. Download PDF.

Kuchins, Andrew et al. 2009. 'The Northern Distribution Network and the Modern Silk Road', CSIS. Download PDF.

Kuehne, Andreas. 2008. Scrutinizing and Assessing the Performance of the German and U.S.-led Provincial Reconstruction Teams in Afghanistan. Naval Postgraduate School Master's Thesis. Download PDF.

Kugler, Richard. 2007. 'Operation Anaconda in Afghanistan: A Case Study of Adaptation in Battle’, Case Studies in Defense Transformation, Number 5. PDF.

Langford, Ian. 2010. 'Australian Special Forces in Afghanistan: Supporting Australia in the 'Long War', Australian Army Journal, Vol. VII, Number 1. Download PDF.

Larsdotter, Kersti. 2008. 'Exploring the utility of armed force in peace operations: German and British approaches in northern Afghanistan’, Small Wars \& Insurgencies, Vol. 19, No.3, pp. 352-373.

Ledford, Edward C. 2009. 'Inception and Early Evolution of a Partnership Doctrine: Building Afghan Army Capacity While Fighting a Counterinsurgency’, Small Wars Journal, August 2009. Download PDF.

Ledwidge, Frank. 2009. 'Justice and Counter-Insurgency in Afghanistan: A Missing Link', The RUSI Journal, Vol. 154, No. 1.

LeGree, Larry. 2010. 'Thoughts on the Battle for the Mind: IO and COIN in the Pashtun Belt', Military Review, September-October 2010. Download PDF.

Leigh, Ryan M. 2010. ‘Thinking the unthinkable: civil war in Afghanistan', SAMS Monograph. Download PDF.

Liebl, Vern. 2007. 'Pushtuns, Tribalism, Leadership, Islam and Taliban: A Short View', Small Wars \& Insurgencies, 18(3), pp. 492 - 510.

Litchfield, John D. 2010. 'Unconventional Counterinsurgency: Leveraging Traditional Social Networks and Irregular Forces in Remote and Ungoverned Areas’ US Army School of Advanced Military Studies. Download PDF.

Lombardi, Ben. 2009. 'Talking to the Enemy: Some thoughts on what that means', Defence R\&D Canada. Download PDF. 
Lopez, Andrea M. 2007. 'Engaging or withdrawing, winning or losing? The contradictions of counterinsurgency policy in Afghanistan and Iraq', Third World Quarterly, Vol. 28, No. 2, pp. 245-260.

Luehrs, Christoff. 2009. 'Provincial Reconstruction Teams: A Literature Review', Prism, Vol. 1, No. 1. Download PDF.

Macdonald. M. G. et al. 2009. 'Afghanistan in-Theatre Detainee Handling Process Board of Inquiry Final Report’, Canadian Forces. Read online.

Maher, William. 2010. 'From the Andes to the Hindu Kush: Colombian Airpower Lessons for Afghanistan’, SAMS Monograph. Link to PDF.

Malevich, John J. and Daryl C. Youngman. 2011. 'The Afghan Balance of Power and the Culture of Jihad', Military Review, May-June. Download PDF.

Maley, William. 2011. 'PRT Activity in Afghanistan: The Australian Experience', in Statebuilding in Afghanistan: Multinational Contributions to Reconstruction. Edited by Nik Hynek and Péter Marton. Routledge.

Malkasian, Carter and Gerald Meyerle. 2009. 'Provincial Reconstruction Teams: How do we know they work?’, Strategic Studies Institute. Download PDF.

Maloney, Sean M. 2008. 'A violent impediment: the evolution of insurgent operations in Kandahar province 2003-07’, Small Wars \& Insurgencies, Vol. 19, No. 2, pp. 201-220.

Maloney, Sean M. 2007. 'Conceptualizing the War in Afghanistan: Perceptions from the Front, 2001-2006’, Small Wars \& Insurgencies, Vol. 18, No. 1.

Mann. S. 2008. 'Taking Interagency Stability Operations to a New Level: The Integration of Special Operation Forces and USAID in Afghanistan', Small Wars Journal. PDF.

Marston, Daniel. 2008. 'Lessons in 21st-Century Counterinsurgency: Afghanistan 20012007', in Counterinsurgency in Modern Warfare, edited by Daniel Marston and Carter Malkasian. Osprey Publishing.

Marston, Daniel. 2008. 'British Operations in Helmand Afghanistan', Small Wars Journal. Download PDF.

Martin, Grant M. 2009. 'Special Operations and Conventional Forces: How to Improve Unity of Effort Using Afghanistan as a Case Study’, SAMS Monograph. Link to PDF.

Marton, Péter and Péter Wagner. 2008. 'The Netherlands and Hungary’s contribution to operations in Afghanistan: Contributing to state-building or to crisis management?', HÍRLEVÉL. Hungarian Institute of International Affairs. Download PDF. 
Marzano. Todd. 2006. 'Criticisms Associated With Operation Anaconda: Can Long Distance Leadership Be Effective?’, Naval War College thesis. Download PDF.

McChrystal, Stanley A. 2009. 'Afghanistan: NATO International Security Assistance Force Commander's Initial Assessment’, NATO/ISAF. Download PDF.

McFeely, Eugene L. 2009. 'Balancing Kinetic Effects of Airpower with Counterinsurgency Objectives in Afghanistan’, United States Army War College Strategic Research Project. Download PDF.

McHugh, Gerard and Lola Gostelow. 2004. 'Provincial Reconstruction Teams and military-humanitarian relations in Afghanistan', Save the Children report. PDF.

McKenna, Suzanne, et al. 2008. 'Agency Stovepipes vs Strategic Agility: Lessons We Need to Learn from Provincial Reconstruction Teams in Iraq and Afghanistan', U.S. House of Representatives, Committee on Armed Services. April 2008 Report. PDF.

Mcnab, R. and E. Mason. 2007. 'Reconstruction, the Long Tail and Decentralisation: An Application to Iraq and Afghanistan’, Small Wars \& Insurgencies, Vol. 18, No. 3.

McNerney, Michael M. 2005. 'Stabilization and reconstruction in Afghanistan: are PRTs a model or a muddle’, Parameters, Vol. 35, No. 4. Download PDF.

Merz, Sebastian. 2007. 'Still on the way to Afghanistan? Germany and its forces in the Hindu Kush’, SIPRI Project Paper. Download PDF.

Meyerle, Jerry, et al. 2010. 'Counterinsurgency on the Ground in Afghanistan: How different units adapted to local conditions' Center for Naval Analyses. PDF.

Millen, Raymond. 2008. 'Aligning a Counterinsurgency Strategy for Afghanistan', Small Wars Journal. Download PDF.

Mills, Greg. 2007. 'Ten Counterinsurgency Commandments from Afghanistan', April 2007. US Army War College. Download PDF.

Minkov, Anton. 2010. 'Counterinsurgency and Ethnic/Sectarian Rivalry in Comparative Perspective: Soviet Afghanistan and Contemporary Iraq', Tribal Engagement Workshop. Download PDF.

Minkov, Anton and Smolynec, Gregory. 2010. ‘4-D Soviet Style: Defence, Development, Diplomacy and Disengagement in Afghanistan During the Soviet Period Part I: State Building', The Journal of Slavic Military Studies, Vol. 23, No. 2. 
Minkov, Anton and Smolynec, Gregory. 2010. '4-D Soviet Style: Defense, Development, Diplomacy, and Disengagement in Afghanistan During the Soviet Period. Part III: Economic Development', The Journal of Slavic Military Studies, Vol. 23, No. 4.

Minkov, Anton and Gregory Smolynec. 2007. '3-D Soviet Style: A Presentation on Lessons Learned from the Soviet Experience in Afghanistan', DRDC Centre for Operational Research \& Analysis, October 2007. Download PDF.

Moeller, Jason P. 2007. Soldiers without uniforms: CIA paramilitary operations in Afghanistan. Thesis (M.S.)--Missouri State University, 2007.

Moore, M. and J. Fussell. 2009. 'Kunar and Nuristan: Rethinking US Counterinsurgency Operations', Institute for the Study of War. Afghanistan Report \#1. Download PDF.

Munson, Mark. 2009. 'Should AF/PAK Hands be South Asia Hands? How the IndiaPakistan Relationship Shapes the War in Afghanistan', Small Wars Journal, December. Download PDF.

Murphy, Jason J. F. 2008. 'Beyond Tables, Templates, and Checklists: Logistical Art', SAMS Monograph. Download PDF.

Nathan, Joanna. 2009. 'A Review of Reconciliation Efforts in Afghanistan', CTC Sentinel, Vol. 2, No. 8. Download PDF.

National Defence Canada. 2008. ‘Counter-Insurgency Operations.’ Download PDF.

NATO/ISAF. 2009. 'ISAF Commander's Counterinsurgency Guidance.’ Download PDF.

NATO. 2008. 'NATO in Afghanistan: Master Narrative as at 6 October 2008', NATO Media Operations Centre. Download PDF.

Noetzel, Timo and Schreer, Benjamin. 2008. 'Counter-what? Germany and CounterInsurgency in Afghanistan', The RUSI Journal, Vol. 153, No. 1, pp. 42-46.

Noetzel, T. and B. Schreer. 2008 'The German Army and Counterinsurgency in Afghanistan', SWP Comments No. 1. Download PDF.

Nuzum, Henry. 2010. 'Shades of CORDS in the Kush: The False Hope of "Unity of Effort" in American Counterinsurgency’, Strategic Studies Institute. Download PDF.

Oliker, Olga. 2004. Aid During Conflicts: Interaction Between Military and Civilian Assistance Providers in Afghanistan. RAND. Download PDF.

Olson, L. 2007. 'Civil-Military Coordination: Challenges and Opportunities in Afghanistan and Beyond', Journal of Military and Strategic Studies, Vol. 10, Issue 1. 
O'Quinn, Charles R.V. 2006. Invisible scalpel: low-visibility operations in the War on Terror. Thesis (MMAS)_U.S. Army CGSC. Download PDF.

OSI/TLO. 2010. 'Strangers at the Door: Night Raids by International Forces Lose Hearts and Minds of Afghans’, Open Society Institute // The Liaison Office. PDF.

PA Consulting. 2009. ‘Dynamic Planning for COIN in Afghanistan.’ Download PDF.

Park, David H. 2010. 'Identifying the Center of Gravity of Afghan Mentoring', Military Review, November-December. Download PDF.

Parker, Michelle. 2006. 'Programming Development Funds to Support a Counterinsurgency: A Case Study of Nangarhar, Afghanistan in 2006', Case Studies in National Security Transformation Number 10. Download PDF.

Pascall, Patrick. 2009. 'The Fire Model of Counterinsurgency: Focusing Efforts to Make an Insurgency Unsustainable’, SAMS Monograph. Link to PDF.

Patterson, Rebecca and Jonathan Robinson. 2011. 'The Commander as Investor: Changing CERP Practices’, PRISM 2, No. 2. Download PDF.

Peters, Gretchen. 2009. 'Incorporating Law Enforcement Interrogation Techniques on the Battlefield’, CTC Sentinel, Vol. 2, Issue 7. Download PDF.

Petit, Brian. 2011. 'The Fight for the Village: Southern Afghanistan, 2010', Military Review, May-June. Download PDF.

Piiparinen, Touko. 2007. 'A Clash of Mindsets? An Insider's Account of Provincial Reconstruction Teams’, International Peacekeeping, Vol. 14, No. 1.

Poitras, Maurice V. 2009. 'Adoptable Afghan Customs or Practices in a Military Operations Environment’, SAMS Monograph. Download PDF.

Pritchard, J. and M. Smith. 2010. 'Thompson in Helmand: Comparing Theory to Practice in British Counter-insurgency Operations in Afghanistan’, Civil Wars, Vol. 12, No. 1.

Proud, Matt. 2011. 'The Coin Environment: The Integration and Execution of Lethal and Non-Lethal Effects at the Tactical Level', Australian Army Journal, Volume VIII, Number 1. Download PDF.

Prugh, Dave. 2010. 'Lessons Learned from Six and a Half Years in Afghanistan', Small Wars Journal, Vol. 6, No. 3. Download PDF.

Raghuvanshi, Vivek. 2010. 'Competitive Intelligence Insight - Dealing with Insurgency in Iraq, Afghanistan and India’, eZine. Link to PDF. 
Rapone, David J. 2010. 'Engaging the Insurgent in Negotiation: Lessons from Northern Ireland Applied to Afghanistan’, SAMS Monograph. Link to PDF.

Rhyne, Richard G. Jr. 2004. Special Forces command and control in Afghanistan. Thesis (MMAS)—U.S. Army Command and General Staff College (CGSC). Download PDF.

Riedel, Bruce. 2009. 'Comparing the U.S. and Soviet Experiences in Afghanistan', CTC Sentinel, Vol. 2, Issue 5. Download PDF.

Rietjens, S. et al. 2009. 'Inter-organisational communication in civil-military cooperation during complex emergencies: a case study in Afghanistan’, Disasters, Vol. 33, No. 3.

Rietjens, S. 2008. 'Managing Civil-Military Cooperation: Experiences from the Dutch Provincial Reconstruction Team in Afghanistan’, Armed Forces and Society, 34(2).

Rietjens, Sebastiaan J. H. 2006. Civil-military cooperation in response to a complex emergency: just another drill? PhD thesis. University of Twente, Netherlands. PDF.

Ringsmose, Jens and Peter Dahl Thruelsen. 2010. 'NATO’s counterinsurgency campaign in Afghanistan: are classical doctrines suitable for alliances?’, UNISCI Discussion Papers, No. 22. Download PDF.

Roe, Andrew M. 2006. 'A Contemporary "Blueprint" for North Atlantic Treaty Organization Provisional Reconstruction Teams in Afghanistan?', Monograph Report, British Army School of Advanced Military Studies. Download PDF.

Rogers, Bruce, Jim Hope and Robert Kemp. 2008. 'PRTs in Afghanistan: A report from the inside’, Foreign Service Journal, Vol. 85, No. 7. Download PDF.

Ruiz, Moses T. 2009. 'Sharpening the Spear: The United States' Provincial Reconstruction Teams in Afghanistan’, MPA thesis, Texas State University. PDF.

Runge, Peter. 2009. 'The Provincial Reconstruction Teams in Afghanistan: Role model for civil-military relations?’, BICC Occasional Paper IV. Download PDF.

Saideman, Stephen M. and David P. Auerswald. 2009. 'NATO at War: Understanding the Challenges of Caveats in Afghanistan’, APSA 2009 Toronto. Link to PDF.

Schreer, Benjamin. 2010. 'Political Constraints: Germany and Counterinsurgency', Security Challenges, Vol. 6, No. 1.

St-Louis, Michel-Henri. 2009. 'The Strategic Advisory Team in Afghanistan: Part of the Canadian Comprehensive Approach to Stability Operations', Canadian Military Journal, Vol. 9, No. 3. Download PDF. 
Salmon, Paul J. 2008. 'The Role of the Provincial Reconstruction Teams in Stability Operations: Reality and Potential’, SAMS Monograph. Download PDF.

Sanders, Gregory. 2009. 'Contracting for Operations in Iraq and Afghanistan', DIIG Current Issues No. 17. CSIS. Download PDF.

Schmidt, Soren. 2009. ‘Afghanistan: Organizing Danish Civil Military Relations’, DIIS Report 15. Download PDF.

Scott, Trent and John Agoglia. 2008. 'Getting the Basics Right: A Discussion on Tactical Actions for Strategic Impact in Afghanistan, Small Wars Journal. Download PDF.

Sedra, M. 2005. 'Civil-Military Relations in Afghanistan: The Provincial Reconstruction Team Debate”, Canadian Institute of Strategic Studies Strategic Datalink, No. 126.

Seitz, Paul T. 2007. 'The Future of the Afghan Insurgency’, USAWC Strategy Research Project. Download PDF.

Sellers, Cameron S. 2007. 'Provincial Reconstruction Teams: Improving Effectiveness', Naval Postgraduate School Master’s Thesis. Download PDF.

Shaw, Geoff and David Spencer. 2003. 'Fighting in Afghanistan: Lessons from the Soviet Intervention, 1979-89’, Defense \& Security Analysis, Vol. 19, No. 2.

Slaikeu, Karl A. 2009. 'Winning the War in Afghanistan: An Oil Spot Plus Strategy for Coalition Forces’, Small Wars Journal, April 2009. Download PDF.

Slaughter, Sean R. 2010. 'Expanding the Qawm: Culturally Savvy Counterinsurgency and Nation-Building in Afghanistan’, SAMS Monograph. Link to PDF.

Snyder, Vic. 2008. 'Strategic Agility for 21st Century Challenges: Interagency Lessons from Provincial Reconstruction Teams’, Address by Rep. Vic Snyder. Audio online.

Spencer, David K. 2009. ‘Afghanistan’s Nangarhar Inc: A Model for Interagency Success’, Military Review, July-August 2009. Download PDF.

Spiszer, John M. 2011. 'Counterinsurgency in Afghanistan—Lessons Learned by a Brigade Combat Team’, Military Review, January-February. Download PDF.

Stapleton, B. 2007. 'The PRT Plan, 2002-2004', in Building State and Security in Afghanistan. W. Danspeckgruber (ed) Woodrow Wilson School. PDF.

Stapleton, B. 2007. 'A Means to what end? Why PRTs are peripheral to the bigger political picture in Afghanistan', Journal of Military and Strategic Studies, Vol. 10(1). 
Sterzer, Marcus et al. 2008. 'Note to File-The Challenge of Centralized Control Faced by the Intelligence Function in Afghanistan’, Canadian Army Journal, 11(2). PDF.

Storr, Dan. 2009. A line in the sand: a historical study of border security during insurgencies and lessons for the contemporary Afghan-Pakistan frontier. MA thesis. Joint Forces Staff College, Joint Advanced Warfighting School. Download PDF.

Strand, Arne. 2010. 'Drawing the lines: the Norwegian debate on civilian-military relations in Afghanistan’, NOREF. Download PDF.

Strickland, R. 2008. 'The Taliban in Afghanistan', Canadian Army Journal, 11(1). $\underline{\text { PDF. }}$

Strickland, Richard Tod. 2007. 'The way of the Pashtun: Pashtunwali', Canadian Army Journal, Vol. 10, No. 3. 2007. Download PDF.

Sturek, Frank. 2007. 'Counter-insurgency in Afghanistan - A Way It Was Done in OEF VII \& ISAF IV (2006) ', $2^{\text {nd }}$ Annual Baltic Conference on Defence. Download PDF.

Summers, William C. 2002. Joint forward operating base elements of command and control. Thesis (MMAS)_U.S. Army Command and General Staff College. PDF.

Thomas, Roy. 2009. 'Origins of the Strategic Advisory Team: Afghanistan', On Track, Vol. 14, No. 1.

Thompson, Carl. 2009. 'Winning in Afghanistan', US Army. Download PDF.

Thruelsen, Peter Dahl. 2010. Fighting an insurgency without unity: NATO in Afghanistan, 2006 to 2010. PhD thesis, University of Copenhagen. PDF.

Thruelsen, Peter Dahl. 2008. 'Counterinsurgency and a Comprehensive Approach: Helmand Province, Afghanistan’, Small Wars Journal. Download PDF.

Thruelsen, Peter Dahl. 2007. 'NATO in Afghanistan: What Lessons are we learning and are we willing to adjust?', Danish Institute for Int. Studies Report No. 14. Download PDF.

Tomasetti, Boyd Jason. 2006. Use of contingency contracting in a deployed environment at the tactical level. Thesis (MMAS)_U.S. Army CGSC. Download PDF.

Turner, L.S. et al. 2010. 'Optimizing Deadly Persistence in Kandahar: Armed UAV Integration in The Joint Tactical Fight', Canadian Army Journal, Vol. 13, No. 1. Download PDF.

Uesugi, Yuji. 2006. 'The Provincial Reconstruction Teams (PRTs) and their Contribution to the Disarmament, Demobilization and Reintegration (DDR) Process in Afghanistan', HIPEC. Download PDF. 
USAID. 2006. 'Provincial Reconstruction Teams in Afghanistan: and interagency assessment’, US Agency for International Development (June 2006). Download PDF.

US Gov. 2009. 'United States Government Integrated Civilian-Military Campaign Plan for Support to Afghanistan.’ Download PDF.

United States Institute of Peace. 20005. 'Oral Histories: Afghanistan Provincial Reconstruction Teams’, USIP. Link to multiple PDFs.

Valadez, Ignacio R. 2009. ‘Afghanistan, A Path to Success’, Naval War College report. Download PDF.

Van Dyke, Carl. 1996. 'Kabul to Grozny: A critique of Soviet (Russian) counterinsurgency doctrine’, The Journal of Slavic Military Studies, Vol. 9, Issue 4.

Vegetius. 2009. 'I Can’t Believe We Are Losing To These Guys', Small Wars Journal, September 2009. Download PDF.

Villarreal, Raymundo, Jr. 2005. Role of the Department of Defense embedded reporter program in future conflicts. Thesis (MMAS)—U.S. Army CGSC. Download PDF.

Westerman, Ian. 2008. 'Provincial Reconstruction in Afghanistan... with Reference to the US Experience in Vietnam', Small Wars Journal, October. PDF.

Williams, Brian Glyn. 2008. 'Talibanistan: History of a Transnational Terrorist Sanctuary’, Civil Wars, Vol. 10, No. 1.

Williams, Brian Glyn. 2008. ‘Afghanistan’s Heart of Darkness: Fighting the Taliban in Kunar Province’, CTC Sentinel, Vol. 1, Issue 11. Download PDF.

Williams, Jason T. 2009. 'Understanding an Insurgency: Achieving the United States' Strategic Objectives in Afghanistan’, SAMS Monograph. Download PDF.

Williams, Matthew W. 2005. 'The British colonial experience in Waziristan and its applicability to current operations’, SAMS Monograph. Download PDF.

Willis, Michael S. 2010. 'Contrasts between American and Afghan warriors, a comparison between two martial cultures', Master's thesis, U.S. Army Command and General Staff College. Download PDF.

Wilner, Alex S. 2010. 'Targeted Killings in Afghanistan: Measuring Coercion and Deterrence in Counterterrorism and Counterinsurgency', Studies in Conflict \& Terrorism, Vol. 33, No. 4.

Zweibelson, Ben. 2010. 'The US in Afghanistan: Follow Sun Tzu rather than Clausewitz to Victory', Small Wars Journal, Vol. 6, No. 11. Download PDF. 


\section{Security Sector: DDR, Militias, ANA, ANP, PMCs and Security Contractors}

Ayub, Fatima, et al. 2009. 'Security Sector Reform in Afghanistan', International Center for Transitional Justice. Download PDF.

Azami, Sharif. 2009. 'The Need for Security Sector Reform in Afghanistan to Curb Corruption’, Peace and Conflict Monitor, November. Read online.

Bhatia, Michael and R. Muggah. 2008. 'The Politics of Demobilization in Afghanistan', in Security and Post-Conflict Reconstruction. Ed. by Robert Muggah. Routledge.

Bhatia, Michael. 2007. 'The Future of the Mujahideen: Legitimacy, Legacy, and Demobilization in Post-Bonn Afghanistan', International Peacekeeping, Vol. 14, No. 1.

Bhatia, Michael, Kevin Lanigan and Philip Wilkinson. 2004. 'Minimal Investments, Minimal Results: The Failure of Security Policy in Afghanistan’, AREU. Download PDF.

Boera, Michael R. and Paul R. Birch. 2011. 'Rebuilding Afghanistan's National Security Forces: Fighting Asymmetry with Symmetry’, Military Review, March-April. PDF.

Brooking, Steve and Susanne Schmeidl. 2008. 'When nobody guards the guards: The quest to regulate private security companies in Afghanistan', Sicherheit und Frieden/Security and Peace, Vol. 4.

Chan, Samuel. 2009. 'Sentinels of Afghan Democracy: The Afghan National Army', Military Review, January-February 2009. Download PDF.

Chan, Samuel. 2007. 'Sentinels of Afghan Democracy: The Afghan National Army', S. Rajaratnam School of International Studies Working Paper No. 128. Download PDF.

CIGI. 2009. 'Security Sector Reform Monitor \#2: Afghanistan’, Center for International Governance Innovation. Download PDF.

CIGI. 2009. 'Security Sector Reform Monitor: Afghanistan [July 2009]', Center for International Governance Innovation. Download PDF.

Clegg, Will. 2009. 'Irregular Forces in Counterinsurgency Warfare', Security Challenges, Volume 5, Number 3. Download PDF. 
Cordesman, Anthony H. 2010. 'Afghan National Security Forces: What It Will Take to Implement the ISAF Strategy’, CSIS. Download PDF.

Cordesman, Anthony H. et al. 2009. 'Winning in Afghanistan: Creating Effective Afghan Security Forces', CSIS. Download PDF.

Cordesman, Anthony. 2009. 'Afghan National Security Forces: Shaping the Path to Victory’, CSIS. Download PDF.

Cordesman, Anthony. 2009. 'Afghan National Security Forces: Shaping Host Country Forces as Part of Armed Nation Building', CSIS. Download PDF.

Cordesman, Anthony H. 2009. 'Shaping Afghan National Security Forces: What It Will Take To Implement President Obama’s New Strategy’, CSIS. Download PDF.

Cronin, Stephanie. 2011. 'Building and Rebuilding Afghanistan's Army: An Historical Perspective', Journal of Military History, Vol. 75, No. 1.

CRS. 2009. 'Department of Defense Contractors in Iraq and Afghanistan: Background and Analysis [December 2009]', Congressional Research Service. Download PDF.

Deflem, Mathieu. 2010. 'Policing Afghanistan: Civilian Police Reform and the Resurgence of the Taliban', in The Routledge Handbook of War and Society: Iraq and Afghanistan. London: Routledge.

Eliason, Eric A. 2008. 'Training Afghan and Iraqi Military Chaplaincies: A Battle-proven Model from an Experiment in Afghan Indigenous Chaplain Training.' Download PDF.

Flight, N. 2010. 'Optimizing Canada’s Commitment to Police Reform in Afghanistan', Canadian Army Journal, Vol. 13, No. 1. Download PDF.

Friesendorf, Cornelius. 2011. 'Paramilitarization and Security Sector Reform: The Afghan National Police’, International Peacekeeping, Vol.18, No.1.

Giustozzi, Antonio. 2009. 'The Afghan National Army: Unwarranted Hope?', The RUSI Journal, Vol. 154, No. 6.

Giustozzi, Antonio. 2008. ‘Afghanistan’s National Army: The Ambiguous Prospects of Afghanization’, Terrorism Monitor, Vol. 6, Issue 9. Read online.

Giustozzi, Antonio. 2008. 'Bureaucratic façade and political realities of disarmament and demobilisation in Afghanistan’, Conflict, Security \& Development, Vol. 8, No. 2.

Giustozzi, Antonio. 2008. 'Shadow Ownership and SSR in Afghanistan', in Local Ownership and Security Sector Reform. Edited by Timothy Donais. LIT Verlag. PDF. 
Giustozzi, Antonio. 2007. 'The privatizing of war and security in Afghanistan: future or dead end?', The Economics of Peace and Security Journal, Vol. 2, No. 1.

Giustozzi, Antonio. 2007. ‘Auxiliary Force or National Army? Afghanistan's 'ANA' and the Counter-Insurgency Effort, 2002-2006’, Small Wars and Insurgencies, Vol. 18, No. 1.

Giustozzi, Antonio. 2003. 'Military Reform in Afghanistan', pp. 23-32 in Brief 28, Confronting Afghanistan's Security Dilemma: Reforming the Security Sector, Mark Sedra (ed.). Bonn International Center for Conversion. Download PDF.

Giustozzi, Antonio. 2002. 'Afghanistan: The Problems of Creating a New Afghan armyand the critical dangers of failure!', International Industrial Information (April). PDF.

Government Accountability Office. 2011. 'Afghan Army Growing, but Additional Trainers Needed; Long-term Costs Not Determined.’ US Government Accountability Office. Download PDF.

Government Accountability Office. 2008. 'Afghanistan Security: U.S. Efforts to Develop Capable Afghan Police Forces Face Challenges and Need a Coordinated, Detailed Plan to Help Ensure Accountability’, U.S. Government Accountability Office. Download PDF.

Government Accountability Office. 2005. 'Afghanistan security: efforts to establish army and police have made progress, but future plans need to be better defined', United States Government Accountability Office (June 2005). Download PDF.

Hartzell, Caroline. 2011. 'Missed Opportunities: The Impact of DDR on SSR in Afghanistan’, USIP. Download PDF.

Helmer, Daniel. 2008. 'Twelve Urgent Steps for the Advisor Mission in Afghanistan', Military Review, July-August 2008. Download PDF.

Howk, Jason C. 2009. 'A Case Study in Security Sector Reform: Learning from Security Sector Reform/Building in Afghanistan (October 2002-September 2003)', Strategic Studies Institute. Download PDF.

International Crisis Group. 2008. 'Policing in Afghanistan: Still Searching for a Strategy', Asia Briefing No. 85. Access online.

Jones, Seth and Arturo Munoz. 2010. ‘Afghanistan's Local War: Building Local Defense Forces', RAND. Download PDF.

Klem, B. and P. Douma. 2008. 'The struggle after combat: the role of NGOs in DDR processes, synthesis study’, CORDAID. Download PDF.

Kouvo, Sari et al. 2009. 'Security Sector Reform in Afghanistan', Initiative for Peacebuilding and International Centre for Transitional Justice. Download PDF. 
Lefèvre, Mathieu. 2010. 'Local Defence in Afghanistan: A review of government-backed initiatives’, Afghanistan Analysts Network. Download PDF.

Legon, Andrew. 2009. 'Ineffective, Unprofessional, and Corrupt: The Afghan National Police Challenge’, Foreign Policy Research Institute. Read Online.

Lurås, Helge. 2010. 'Build-up of Afghan security forces ill advised', Norwegian Institute of International Affairs (NUPI). Download PDF.

Marten, Kimberly. 2009. 'The Danger of Tribal Militias in Afghanistan', Journal of International Affairs, Vol. 63, No. 1.

McBrewster, John et al (Eds.). 2009. Afghan National Army: Battle of Musa Qala, Operation Panther's Claw, Operation Strike of the Sword, Afghan National Army Air Corps. Alphascript Publishing.

Murray, Tonita. 2007. Police-Building in Afghanistan: A Case Study of Civil Security Reform', International Peacekeeping, 14(1), pp. 108-126.

O’Brien, Paul and Paul Barker. 2003. 'Old Questions Needing New Answers: A Fresh Look at Security Needs in Afghanistan’, in Confronting Afghanistan’s Security Dilemma: Reforming the Security Sector, Mark Sedra (ed.). BICC. Download PDF.

Oxfam. 2011. 'No Time to Lose Promoting the Accountability of the Afghan National Security Forces.’ Download PDF.

Perito, Robert M. 2009. 'Afghanistan’s Police: The Weak Link in Security Sector Reform’, USIP. Download PDF.

Pomper, Stephen D. 2005. 'Don’t Follow the Bear: The Soviet Attempt to Build Afghanistan’s Military’, Military Review, (Sept.-Oct.). Download PDF.

Rossi, Simonetta and Antonio Giustozzi. 2006. 'Disarmament, demobilization, and reintegration of ex-combatants (DDR) in Afghanistan: constraints and limited capabilities', Crisis States Research Centre, Working paper no. 2, series 2. PDF.

Roy, Olivier. 1989. 'La formation de l'armée en Afghanistan', in Entre l'Iran et l'Occident. dir. Yann Richard. - Paris : Maison des sciences de l'homme.

Rubin, B. 2003. 'Identifying Options and Entry Points for Disarmament, Demobilization, and Reintegration in Afghanistan', in Confronting Afghanistan's Security Dilemma: Reforming the Security Sector. Mark Sedra (ed.). BICC. Download PDF. 
Stapleton, Barbara. 2009. 'Disarming the Militias - DDR and DIAG and the Implications for Peace Building', Swedish Committee for Afghanistan Conference: Peace Building in Afghanistan. Download PDF.

Schetter, Conrad. 2002. 'Challenging the warlord culture: security sector reform in postTaliban Afghanistan’, BICC Paper \#25. Download PDF.

Schmeidl, Susanne and Karokhail, Masood. 2009. 'The Role of Non-State Actors in 'Community-Based Policing' - An Exploration of the Arbakai (Tribal Police) in SouthEastern Afghanistan', Contemporary Security Policy, Vol. 30, No. 2.

Schmeidl, Susanne. 2009. 'The Good, the Bad and the Ugly - The Private Military and Security Sector in Afghanistan', in Alex Dowling and Eden Cole (eds.) Security Sector Governance in Afghanistan. DCAF.

Schmeidl, Susanne. 2008. 'Case Study Afghanistan', pp.9-38 in Ulrike Joras and Adrian Schuster (eds.) Private Security Companies and Local Populations: An Exploratory Study of Afghanistan and Angola. Working Paper 1/2008. Download PDF.

Schmeidl, Susanne. 2007. 'Case Study Afghanistan - Who Guards the Guardians?', pp.14-45 in Private Security Companies and Local Populations. An exploratory study of Afghanistan and Angola. Swisspeace report. Download PDF.

Schwartz, Moshe. 2010. 'The Department of Defense’s Use of Private Security Contractors in Iraq and Afghanistan: Background, Analysis, and Options for Congress', Congressional Research Service. Download PDF.

Sedra, Mark. 2010. 'Missed Opportunities: The European Union and Security Sector Reform in Afghanistan', in The Politics of Security Sector Reform: Challenges and Opportunities for the European Union's Global Role. Edited by Magnus Ekengren and Greg Simons. London: Ashgate.

Sedra, Mark. 2006. European Approaches to Security Sector Reform: Examining Trends through the Lens of Afghanistan', European Security, Vol. 15, No. 3.

Sedra, Mark. 2006. 'Security Sector Reform in Afghanistan: The Slide towards Expediency’, International Peacekeeping, Volume 13, Number 1.

Sedra, Mark. (ed.) 2003. Confronting Afghanistan's Security Dilemma: Reforming the Security Sector, Bonn International Center for Conversion. Download PDF.

Sedra, Mark. 2003. 'Introduction', in Brief 28, Confronting Afghanistan’s Security Dilemma: Reforming the Security Sector. Mark Sedra (ed.). BICC. Download PDF.

Sedra, Mark. 2003. 'Police Reform in Afghanistan: An Overview', pp. 32-39 in Brief 28, Mark Sedra (ed.). Bonn International Center for Conversion, September 2003. PDF. 
Sherman, Jake and Victoria DiDomenico 2009. 'The Public Cost of Private Security in Afghanistan', Center on International Cooperation. Download PDF.

Simonelli, M. 2009. Riding a Donkey Backwards Through Afghanistan. Mill City Press.

Skinner, Marcus. 2008. 'Counterinsurgency and State Building: An Assessment of the Role of the Afghan National Police’, Democracy and Security, Vol. 4, No. 3.

Stevens, Michael. 2011. 'Community Defence In Afghanistan: A Model For Future Stabilisation?’, The RUSI Journal, Volume 156, Issue 3.

US Senate. 2010. 'Inquiry into the role and oversight of private security contractors in Afghanistan’, Armed Services Committee. Download PDF.

Various authors. 2008. 'Oversight of U.S. Efforts to Train and Equip Police and Enhance the Justice Sector in Afghanistan’, Subcommittee on National Security and Foreign Affairs oversight hearing. Download PDF.

Waltemate, Sascha. 2011. 'Focused District Development - Turning Point for Police Building in Afghanistan?’, DIAS-Analysen No. 47. Link to PDF.

Wilder, Andrew. 2007. 'Cops or Robbers? The Struggle to Reform the Afghan National Police', AREU. Download PDF.

Younossi, Obaid. 2009. The Long March: Building an Afghan National Army.

RAND. Download PDF. 


\section{Population Movements: Refugees, IDPs and Migration}

\section{$\underline{\text { Books }}$}

Centlivres, Pierre and Micheline Centlivres-Demont 2010. Afghanistan on the Threshold of the 21st Century: Three Essays on Culture and Society. Markus Wiener Publishers.

Chatty, Dawn. (Ed.). 2010. Deterritorialized Youth: Sahrawi and Afghan Refugees at the Margins of the Middle East. Berghahn Books.

Shalinsky, Audrey C. 1994. Long Years of Exile: Central Asian Refugees in Afghanistan and Pakistan. University Press of America: Lanham, MD/London.

Harpviken, Kristian Berg. 2009. Social Networks and Migration in Wartime Afghanistan. Palgrave Macmillan.

Oeppen, Ceri and Angela Schlenkhoff (eds.). 2010. Beyond the 'Wild Tribes':

Understanding Modern Afghanistan and Its Diaspora. Hurst \& Co.

\section{$\underline{\text { Journal articles and book chapters }}$}

Abbasi-Shavazi, Mohammad Jalal et al. 2008. 'Second-generation Afghans in Iran: Integration, Identity and Return’, AREU. Link to PDF.

Abbasi-Shavazi, M.J. and Diana Glazebrook. 2006. 'Continued Protection, Sustainable Reintegration: Afghan Refugees and Migrants in Iran’, AREU. Download PDF.

Abdoullaev, K. 1994. 'Central Asian Emigres in Afghanistan: First Wave 1920-1931', Central Asia Monitor, No. 5.

Adelkhah, F. and Z. Olszewska. 2007. 'The Iranian Afghans', Iranian Studies, 40(2).

Azizi, F., K. et al. 2008. 'Mental health problems prevalence and the associated effective demographic factors in Afghan refugees resettled in Dalakee refugee camp in 2005', European Psychiatry, Volume 23, Supplement 2, April 2008.

Baiza, Yahia. 2002. Issues and challenges of higher education for Afghan Ismaili refugees in Pakistan. Thesis (M. Sc.)--University of Oxford.

Barton, Michel S. 1984. 'A Welcome to Mujahiristan’, Refugees 4: 21-27.1984 
Bialczyk, Agata. 2008. “Voluntary Repatriation’ and the Case of Afghanistan: A Critical Examination’, RSC Working Paper No. 46. Download PDF.

Blitz, Brad K. Rosemary Sales, and Lisa Marzano. 2005. 'Non-Voluntary Return? The Politics of Return to Afghanistan’, Political Studies, Volume 53 Issue 1 (March 2005).

Boesen, Inger W. 1985. 'From Autonomy to Dependency: Aspects of the "Dependency Syndrome” Among Afghan Refugees’, Migration Today 13(5): 17-21.

Boesen, Inger W. 1986. 'Honour in Exile. Continuity and Change among Afghan Refugees’, Folk 28: 109-124.

Braakman, Marije and Angela Schlenkhoff. 2007. 'Between Two Worlds: Feelings of Belonging While in Exile and the Question of Return’, Asien 104 (July 2007). PDF.

Centlivres, Pierre, and Michelene Centlivres-Demont. 1987. 'Sociopolitical Adjustment Among Afghan Refugees in Pakistan’, Migration World 15(4): 15-21.

Centlivres, Pierre, and Michelene Centlivres-Demont. 1988. 'The Afghan Refugees in Pakistan: A Nation in Exile’, Current Sociology 36(2): 71-92.

Centlivres, Pierre, and Michelene Centlivres-Demont. 1988. 'The Afghan Refugee in Pakistan: An Ambiguous Identity’, Journal of Refugee Studies 1(2): 141-152.

Clifford, James. 1997. 'The Biggest Caseload in the World', Refugees II(108):3.

Collective for Social Science Research. 2006. 'Afghans in Peshawar: Migration, Settlements and Social Networks’, AREU. Download PDF.

Collective for Social Science Research. 2006. 'Afghans in Pakistan: Broadening the Focus', AREU. Download PDF.

Collective for Social Science Research. 2006. 'Afghans in Quetta: Settlements, Livelihoods, Support Networks and Cross-Border Linkages’, AREU. Download PDF.

Collective for Social Science Research. 2005. 'Afghans in Karachi: Migration, Settlement and Social Networks', AREU. Download PDF.

Dossa, Parin. 2008. Creating Politicized Spaces: Afghan Immigrant Women’s Stories of Migration and Displacement', Affilia, 23; 10.

Dupree, Louis. 1975. 'Settlement and Migration Patterns in Afghanistan: A Tentative Statement', Modern Asian Studies 9(3): 397-413. 
Dupree, Louis. 1988. 'Cultural Changes Among the Mujahidin and Muhajerin', in The Tragedy of Afghanistan: The Social, Cultural and Political Impact of the Soviet Invasion. Huldt and E. Jansson, eds. Pp. 20-37. London: Croom Helms.

Edwards, David B. 1986. 'Marginality and Migration: Cultural Dimensions of the Afghan Refugee Problem’, International Migration Review 20(2): 313-325.

Faculty of Social Science, University of Tehran. 2005. 'Return to Afghanistan? A Study of Afghans Living in Tehran', AREU. Download PDF.

Faculty of Social Sciences, University of Tehran. 2005. 'Return to Afghanistan? A Case Study of Afghans Living in Zahedan’, AREU. Download PDF.

Faculty of Social Sciences, University of Tehran. 2005. 'Return to Afghanistan? A Case Study of Afghans Living in Mashhad’, Islamic Republic of Iran’, AREU. PDF.

Glatzer, Bernt. 1979. 'Afghan Nomads Trapped in Pakistan', in The Tragedy of 1979 Afghanistan: The Social, Cultural and Political Impact of the Soviet Invasion. B. Huldt and E. Jansson, eds. Pp. 240-247. London: Croom Helm.

Glazebrook, Diana et al. 2007. 'Pilgrimage Practices and Return Intentions of Hazara Afghan Refugees Living in Mashad, Iran’, Iranian Studies, Vol. 40, No. 2.

Green, Nile. 2008. 'Tribe, Diaspora, and Sainthood in Afghan History', The Journal of Asian Studies, Vol. 67, No. 1, pp. 171-211.

Habibi, Gulbadin and Pamela Hunte. 2006. 'Afghan Returnees from NWFP, Pakistan to Nangarhar Province’, AREU. Download PDF.

Hanifi, Shah Mahmoud. 2006 'Material and Social Remittances to Afghanistan', Chapter 4 in Converting Migration Drains into Gains Harnessing the Resources of Overseas Professionals. Asian Development Bank (October 2006). Download PDF.

Hanifi, M. Jamil. 2000. 'Anthropology and the representations of Recent Migrations from Afghanistan’, Rethinking Refuge and Displacement: Selected Papers on Refugees and Immigrants, Volume VIII. pp. 291-321. American Anthropology Association.

Howell, David R. 1982 Refugee Resettlement and Public Policy: A Role for Anthropology. Anthropological Quarterly 65(3): 119-126.

Human Rights Watch. 2002. 'Closed Door Policy: Afghan Refugees in Pakistan and Iran', Vol. 14, No. 2(G). Download PDF.

Hussain, Nazir. 2004. Organization of the Hazara Youth: The Case of Tanzeem Nasle Nau Hazara Mughal in Quetta, Pakistan, JCAS Symposium Series, 21. 
ICG. 2009. 'Afghanistan: What Now for Refugees?’, Asia Report No. 175.

IDMC. 2010. 'Armed Conflict Forces Increasing Numbers of Afghans to Flee Their Homes’, Internal Displacement Monitoring Forces. Download PDF.

IDMC. 2008. 'Afghanistan: Increasing hardship and limited support for growing displaced population’, Internal Displacement Monitoring Centre. Download PDF.

Jazayery, Leila. 2002. 'The Migration-Development Nexus: Afghanistan Case Study', International Migration, Vol. 40, No. 5.

Koettl, Johannes, Negar Ghobadi and Renos Vakis. 2005. 'Moving Out of Poverty: Migration Insights from Rural Afghanistan’, AREU. Download PDF.

Koser, Khalid and Susanne Schmeidl. 2009 'Displacement, Human Development, and Security in Afghanistan’, pp.8-22 in Hady Amr (ed) Displacement in the Muslim World: A Focus on Afghanistan and Iraq. Saban Center. Download PDF.

Kronenfeld, Daniel A. 2008. 'Afghan Refugees in Pakistan: Not All Refugees, Not Always in Pakistan, Not Necessarily Afghan?', Journal of Refugee Studies, February.

Lewis, Meredith. 2005. 'Conference on Afghan Population Movements (Kabul): Summary Report (Migration and Transnational Networks)', AREU. Download PDF.

Lipson, Juliene G., and Patricia A. Omidian. 1992. 'Health Issues of Afghan Refugees in California', The Western Journal of Medicine 157(3): 271-274.

Majidi, Nassim, 2008. 'Research Study on Afghan Deportees from Iran', Altai Consulting for ILO-UNHCR. Download PDF.

Majidi, Nassim. 2009. 'Understanding the Return and Reintegration Process of Afghan Returnees from the UK', DFID. Download PDF.

Majidi, Nassim. 2009. 'Study on Cross Border Population Movements between Afghanistan and Pakistan’, UNHCR. Download PDF.

Malik, Abdul Hamid and Masood, Alauddin. 1985, 2000. Impelled Afghan migration to Pakistan, 1978-1984. Thesis (Ph. D.)--Area Study Centre, University of Peshawar.

Margesson, Rhoda. 2007. 'Afghan Refugees: Current Status and Future Prospects', CRS Report for Congress. Download PDF.

Marsden, Peter and David Turton. 2002. 'Taking Refugees for a Ride? The Politics of Refugee Return to Afghanistan’, AREU. Download PDF. 
Martin, Randolph. 2000. 'Regional Dynamics and the Security of Afghan refugees in Pakistan’, Refugee Survey Quarterly, Vol. 19, No. 1.

McCleskey, Edward R. 2003. Repatriation and reintegration in Afghanistan: the role of demilitarization. Master of Studies in Forced Migration, Oxford University.

Mendes, Susan M. 1988. Nutritional, health and socioeconomic status of Afghan refugees in Baluchistan Province, Pakistan. Thesis (M.P.H.)--University of Sydney.

Monsutti, Alessandro.2010. 'Towards a Transnational Community: Migration and Remittances among the Hazaras', in Ethnicity, Authority, and Power in Central Asia: New Games Great and Small. Edited by Robert L. Canfield and Gabriele RasulyPaleczek. Routledge.

Monsutti, Alessandro. 2008. 'Afghan Migratory Strategies and the Three Solutions to the Refugee Problem’, Refugee Survey Quarterly, Vol. 27, No. 1.

Monsutti, Alessandro. 2007. 'Migration as a Rite of Passage: Young Afghans Building Masculinity and Adulthood in Iran', Iranian Studies, Vol. 40, No. 2.

Monsutti, Alessandro. 2006. ‘Afghan Transnational Networks: Looking Beyond Repatriation’, AREU. Download PDF.

Mundt, Alexander and Susanne Schmeidl, 2009. 'The Failure to Protect: Battle-Affected IDPs in Southern Afghanistan', The Brookings-Bern Project on Internal Displacement / The Liaison Office. Read online.

Mundt, Alexander, Susanne Schmeidl and Shafiqullah Ziai. 2009. 'Between a Rock and a Hard Place: The Return of Internally Displaced Persons to Northern Afghanistan', The Brookings-Bern Project on Internal Displacement/The Liaison Office. Read online.

Novak, Paolo. 2007. 'Place and Afghan Refugees: A Contribution to Turton', Journal of Refugee Studies, Vol. 20, No. 4.

Olszweska, Zuzanna. 2007. “'A Desolate Voice”: Poetry and Identity among young Afghan Refugees in Iran’, Iranian Studies, Vol. 40, No. 2.

Omidian, Patricia A. 1992. Aging and Intergenerational Conflict: Afghan Refugee Families in Transition. Ph.D. Dissertation. University California, San Francisco.

Omidian, Patricia A. 1996. Aging and Family in an Afghan Refugee Community. New York: Garland Publishing.

Opel, Aftab. 2005. 'Bound for the City: A Study of Rural to Urban Labour Migration in Afghanistan’, AREU. Download PDF. 
Özerdem, Alpaslan and Abdul Hai Sofizada. 2006. 'Sustainable reintegration to returning refugees in post-Taliban Afghanistan: land-related challenges Analysis', Conflict, Security and Development, Volume 6, Number 1: pg 75-100. (April 2006).

Pedersen, Gorm. 1992. 'Afghan Nomads in Exile: Patterns of Organization and Reorganization in Pakistan', in The Cultural Basis of Afghan Nationalism. E. W. Anderson and N. H. Dupree, eds. Pp. 154-159. London: Pinter Publishers.

Punjani, Shahid. 2002. 'How Ethno-Religious Identity Influences the Living Conditions of Hazara and Pashtun Refugees in Peshawar, Pakistan', Working Paper \#14, Department of Urban Studies and Planning, MIT, Cambridge, MA. August 2002. Download PDF.

Rastegar, Farhad. 1991. Education and revolutionary political mobilization: schooling versus uprootedness as determinants of Islamic political activism among Afghan refugee students in Pakistan. Dissertation.

Refugees International. 2010. 'Afghanistan: In a Time of Conflict', Refugees International, Field Report. Download PDF.

Refugees International. 2009. 'Afghanistan and Pakistan: Raise Voices for Civilian Protection’, Refugees International. Download PDF.

Refugees International. 2008. ‘Afghanistan: Invest in People.’ Download PDF.

Rizvi, Gowher. 1990. 'The Afghan refugees: hostages in the struggle for power', Journal of Refugee Studies, Vol. 3, No. 3, p. 244-261.

Rodan, Debbie and Lange, Cheryl. 2008. 'Going Overboard? Representing Hazara Afghan Refugees as Just Like Us’, Journal of Intercultural Studies, 29(2), pp. 153-169.

Rostami-Povey, Elaheh. 2007. 'Afghan Refugees in Iran, Pakistan, the U.K. and the U.S. and Life after Return: A Comparative Gender Analysis’, Iranian Studies, Vol. 40, No. 2.

RSC. 2008. 'Voluntary Repatriation' and the Case of Afghanistan: A Critical Examination Source’, Refugee Studies Centre. Download PDF.

Saito, Mamiko. 2009. 'Dilemmas Between Borders: Experiences of young Afghans returning “Home” from Pakistan and Iran', AREU. Download PDF.

Saito, Mamiko. 2008. 'From Disappointment to Hope: Transforming Experiences of Young Afghans Returning “Home” from Pakistan and Iran’, AREU. Download PDF.

Saito, Mamiko. 2008. 'Second-Generation Afghans in Neighbouring Countries, "From Mohajer to Hamwatan: Afghans Return Home', AREU (Jan 2008). Download PDF. 
Saito, Mamiko and Pamela Hunte. 2007. 'To Return or to Remain: The Dilemma of Second-Generation Afghans in Pakistan', AREU. Download PDF.

Schmeidl, Susanne. 2009. 'Repatriation to Afghanistan: durable solution or responsibility shifting?', Forced Migration Review, No. 33.

Schmeidl, Susanne. 1994. 'Ethnic Dynamics in Forced Migration: A Comparison of Afghan and Palestinian Refugees’, International Journal of Group Tensions, 24(4).

Schmeidl, Susanne and William Maley. 2008. 'The Case of the Afghan Refugee Population: Finding Durable Solutions in Contested Transitions', pp.131-179 in Howard Adelman (ed.) Protracted Displacement in Asia: No Place to Call Home. Ashgate.

Schöch, Rüdiger. 2008. 'UNHCR and the Afghan Refugees in the Early 1980s: Between Humanitarian Action and Cold War Politics’, Refugee Survey Quarterly, Vol. 27, No. 1.

Shahrani, M. Nazif. 1984. ‘Afghanistan’s Kirghiz in Turkey’, Cultural Survival Quarterly 8(1): 31-34.

Shahrani, M. Nazif. 1995. ‘Afghanistan’s Muhajirin (Muslim “Refugee-Warriors”):

Politics of Mistrust and Distrust of Politics', in Mistrusting Refugees. E. V. Daniel and J.

C. Knudsen, eds. Pp. 187-206. Berkeley: University of California Press.

Shahrani, M. Nazif. 2001. 'Pining for Bukhara in Afghanistan: Poetics and politics of Exilic Identity and Emotions', In Reform Movements and Revolutions in Turkistan 19001924. Edited by Timur Kocaoglu. Haarlem, Netherlands: SOTA, pp. 369-391.

Shalinsky, Audrey. 1991. 'The Aftermath of Fieldwork in Afghanistan: Personal Politics', Anthropolgy and Humanism Quarterly, 16(1).

Shorish-Shamley, Zieba Nisa. 1991. The Self and Other in Afghan Cosmology: Concepts of Health and Illness among Afghan Refugees. Ph.D. Dissertation. University of Wisconsin-Madison.

Stigter, Elca and Alessandro Monsutti. 2005 'Transnational Networks: Recognising a Regional Reality’, AREU. Download PDF.

Stigter, Elca. 2005. ‘Transnational Networks and Migration from Herat to Iran’, AREU. Download PDF.

Stigter, Elca. 2004. 'The Kandahar Bus Stand in Kabul: An Assessment of Travel and Labour Migration to Iran and Pakistan', AREU. Download PDF.

Stigter, Elca. 2004. 'February 2005 Transnational Networks and Migration from Faryab to Iran', AREU. Download PDF. 
Stigter, Elica. 2004. 'Uzbek IDPs in Western Afghanistan', FMR 21. Download PDF.

Strand, Arne et al. 2008. 'Return in Dignity, Return to What?: Review of the Voluntary Return Programme to Afghanistan’, CMI Report \#6. Download PDF.

Swedish Committee for Afghanistan. 1993. 'Repatriation and Rehabilitation of Afghan Refugees', Peshawar, Pakistan.

Sweetser, Anne. 1984. 'Afghan Nomad Refugees in Pakistan’, Cultural Survival Quarterly 8(1): 26-30.

Tamang, Ritendra. 2009. 'Afghan Forced Migration: Reaffirmation, Redefinition, and the Politics of Aid', Asian Social Science, Vol. 5, No 1. Download PDF.

Tober, Diane. 2007. 'Introduction: Afghan Refugees and Returnees', Iranian Studies, Vol. 40, No.2.

Tober, Diane. 2007. “'My Body is Broken Like My Country”: Identity, Nation, and Repatriation among Afghan Refugees in Iran', Iranian Studies, Vol. 40, No. 2.

Zahedi, Ashraf. 2007. 'Transnational Marriages, Gendered Citizenship, and the Dilemma of Iranian Women Married to Afghan Men’, Iranian Studies, Vol. 40, No. 2.

Zeleny, Beth Ann. 2000. Gendered space in Afghan refugee camps. PhD dissertation. The Pennsylvania State University, 2000.

Zieck, M. 2008. 'The Legal Status of Afghan Refugees in Pakistan, a Story of Eight Agreements and Two Suppressed Premises', Int. Journal of Refugee Law, Vol. 20, No. 2. 


\section{The Afghanistan Analyst}

Bibliography \#13

\section{Health and Medicine}

Acerra, John R. et al. 2009. 'Rebuilding the health care system in Afghanistan: an overview of primary care and emergency services', International Journal of Emergency Medicine, Vol. 2, No. 2.

Arur, Aneesa et al. 2009. 'Contracting for health and curative care use in Afghanistan between 2004 and 2005', Health Policy and Planning, Oct. 2009.

Brezinski, Paul et al. 2009. 'Health Sector Development in Afghanistan: The Way Forward’, The Army Medical Department Journal, April-June 2009. Download PDF.

Graham, C. and S. Chattopadhyay. 2009. 'Well-being and Public Attitudes in Afghanistan', World Economics, 10(3).

Hemat, Shafiqullah et al. 2009. 'Health-care provision factors associated with child immunization coverage in a city centre and a rural area in Kabul, Afghanistan', Vaccine, Volume 27, Issue 21.

Loevinsohn, B. and G. D. Sayed. 2008. 'Lessons From the Health Sector in Afghanistan: How Progress Can Be Made in Challenging Circumstances’, JAMA, 300(6).

Mayhew, Maureen. 2009. 'Shame and simplicity in Afghanistan', CMAJ, Vol. 180(8).

McNiff Lindholm, Meghann. 2008. ‘Winning the peace - In service of Afghanistan’s most vulnerable population', Maternal and Child Health Departments // Boston University School of Public Health. Download PDF.

Miller, Kenneth et al. 2009. 'The Validity and Clinical Utility of Post-traumatic Stress Disorder in Afghanistan’, Transcultural Psychiatry, Vol. 46, No. 2.

Miller, Kenneth E. et al 2008. 'Daily Stressors, War Experiences, and Mental Health in Afghanistan’, Transcultural Psychiatry, Vol. 45, No. 4.

Miller, Kenneth., Et al. 2006. 'The Afghan Symptom Checklist: A Culturally Grounded Approach to Mental Health Assessment in a Conflict Zone', American Journal of Orthopsychiatry,Vol. 76, No. 4, 423-433.

Morikawa, Masahiro J. 2008. 'Effect of security threats on primary care access in Logar province, Afghanistan’, Medicine, Conflict and Survival, Vol. 24, No. 1, pp. 59-64. 
Panter-Brick, Catherine et al. 2009. 'Violence, suffering, and mental health in Afghanistan: a school-based survey’, The Lancet, Volume 374, Issue 9692.

Raj, Anita, Charlemagne Gomez and Jay G. Silverman. 2008. 'Driven to a Fiery Death The Tragedy of Self-Immolation in Afghanistan', New England Journal of Medicine, Vol. 358, No. 21.

Ridde, Valéry. 2005. 'Performance-based partnership Agreements for the reconstruction of the health system in Afghanistan', Development in Practice, Volume 15, Number 1 (February 2005), pp. 4-15.

Saif-ur-Rehman, Mohammad Zafar Rasoul, Alex Wodak, Mariam Claeson, Jed Friedman and Ghulam Dastagir Sayed. 2007. 'Responding to HIV in Afghanistan', The Lancet 2007; 370: pp. 2167-2169.

Steinhardt, Laura et al. 2009. 'The effect of wealth status on care seeking and health expenditures in Afghanistan', Health Policy and Planning, Vol. 24, No. 1.

Todd, Catherine S. et al. 2011. 'HIV awareness and condom use among female sex workers in Afghanistan: implications for intervention', AIDS Care, Vol. 23, Issue 3.

Todd, C. S. et al. 2009. 'Prevalence and correlates of HIV, syphilis, and hepatitis knowledge among intrapartum patients and health care providers in Kabul, Afghanistan', AIDS Care, Vol. 21, No. 1.

Todd, Catherine S. et al. 2009. 'A Cross-Sectional Assessment of Utilization of Addiction Treatment among Injection Drug Users in Kabul, Afghanistan', Substance Use \& Misuse, Vol. 44, Issue 3.

Todd, Catherine et al. 2008. 'Correlates of Receptive and Distributive Needle Sharing Among Injection Drug Users in Kabul, Afghanistan', The American Journal of Drug and Alcohol Abuse, Vol. 34, No. 1, pp. 91-100.

Todd, CS, et al. 2007. 'HIV, hepatitis C, and hepatitis B infections and associated risk behavior in injection drug users, Kabul, Afghanistan’, Emerging Infectious Diseases, September 2007.

Trani, Jean-Francois and Parul Bakhshi. 2008. 'Challenges for assessing disability prevalence: The case of Afghanistan’, Revue européenne de recherché sur le handicap, Vol. 2, pp. 44-64.

Tuhkanen, Sirpa et al. 2008. 'A disaster preparedness and response project in Afghanistan: participants' perceptions', Journal of Advanced Nursing, Vol. 64 Issue 3.

Waldman, Ron, Leslie Strong, Abdul Wali. 2007 'Afghanistan's Health System Since 2001: Condition Improved, Prognosis Cautiously Optimistic’, AREU. Download PDF. 
Waldman, Ronald and Homaira Hanif. 2002. 'The Public Health System in Afghanistan', AREU (July 2002). Download PDF.

Wright, Kevin. 2009. 'Afghanistan: An assessment of the status of health care and pharmacy mentoring efforts in an Afghan National Army Hospital', Journal of the American Pharmacists Association, Vol. 49, No. 5.

Jones, Seth et al. 2006. 'Securing Health: Lessons from Nation-Building Missions', RAND. Download PDF.

Thompson, Donald F. 2008. 'The Role of Medical Diplomacy in Stabilizing Afghanistan', Defense Horizons, May 2008. Download PDF. 


\section{Education}

Affolter, Friedrich et al. 2009. 'Transformative learning and mind-change in rural Afghanistan', Development in Practice, Volume 19, Number 3.

Baehr, Peter. 2009. ‘An American University in Afghanistan’, Society, Vol. 46, No. 1.

Balwanz, D. 2008. 'Meeting EFA: Afghanistan community schools', Educational Quality Improvement Program, USAID. Download PDF.

de Berry, Joanna. 2008. 'The Challenges of Programming with youth in Afghanistan', in Jason Hart (ed.), Years of Conflict. Berghahn Books.

Burde, Dana and Leigh L. Linden. 2010. 'The Effect of Village-Based Schools: Evidence from a RCT in Afghanistan', J-PAL. Download PDF.

Glad, Marit et al 2009. 'Knowledge on Fire: Attacks on Education in Afghanistan: Risks and Measures for Successful Mitigation’, Care Canada. Download PDF.

Guimbert, Stephane et al. 2008. 'Back to school in Afghanistan: Determinants of school enrollment', International Journal of Educational Development, Volume 28, Issue 4.

HRRAC. 2007. 'Is Government-Provided Basic Education Fulfilling Afghan Children's Rights?’, The Human Rights Research and Advocacy Consortium. Download PDF.

Human Rights Watch. 2006. 'Lessons in terror: attacks on education in Afghanistan', Human Rights Watch Report, Vol. 18, No. 6(C) July 2006. Download PDF.

Hunte, Pamela. 2006. 'Looking Beyond the School Walls: Household Decision-Making and School Enrolment in Afghanistan', AREU. Download PDF.

Hunte, Pamela. 2005. 'Household Decision-Making and School Enrolment in Afghanistan: Case Study \#4: District 2, Kandahar City’, AREU. Download PDF.

Hunte, Pamela. 2005. 'Household Decision-Making and School Enrolment in Afghanistan: Case Study \#3: Nesher Villages, Belcheragh District, Faryab Province’, AREU. Download PDF.

Hunte, Pamela. 2005. 'Household Decision-Making and School Enrolment in Afghanistan: Case Study \#2: District 13, Pul-i-Khushk, Kabul City’, AREU. PDF. 
Hunte, Pamela. 2005. 'Household Decision-Making and School Enrolment in Afghanistan: Case Study \#1: Chahar Asyab District, Kabul Province’, AREU. PDF.

Jones, Adele. 2009. 'Curriculum and Civil Society in Afghanistan', Harvard Educational Review, Vol. 79, No. 1. Download PDF.

Karlsson, P. 2008. 'Islamic and modern education in Afghanistan: conflictual or complementary?’, NREED Download PDF.

Killebrew-Conwell, Elizabeth. 'Afghanistan: Education and Literacy', Small Wars Journal, November. Download PDF.

Kirka, Jackie and Rebecca Winthrop. 2008. 'Home-based school teachers in Afghanistan: Teaching for tarbia and student well-being', Teaching and Teacher Education, Vol. 24.

Matsumoto, Yukitoshi. 2008. 'Education for Demilitarizing Youth in Post-Conflict Afghanistan', Research in Comparative and International Education, Vol. 3, No. 1.

Mookerjea, Sourayan. 2009. 'Herouxville's Afghanistan, or, Accumulated Violence', Review of Education, Pedagogy, and Cultural Studies, Volume 31, Issue 2\&3.

Naumann, Craig. 2009. Books, Bullets and Burqas: Anatomy of crisis: educational development, society and the state in Afghanistan. Xlibris.

Naumann, Craig C. 2009. 'Public Education in Afghanistan.’ Read online.

Nolan, Leigh. 2006. 'Afghanistan, Education and the Formation of the Taliban', MA Thesis. Tufts University. Download PDF.

Sigsgaard, Morten. 2009. 'Education and fragility in Afghanistan: a situational analysis', UNESCO/IIEP/INEE. Download PDF.

Spink, Jeaniene. 2005. 'Education and Politics in Afghanistan', Journal of Peace Education, Volume 2, Number 2 (September 2005): pages195-207.

Spink, Jeanine et al. 2004. 'Teacher Education and Professional Development in Afghanistan', AREU. Download PDF.

Williams, C. and F. Yazdani. 2009. 'The Rehabilitation Paradox: Street-Working Children in Afghanistan', Diaspora, Indigenous, and Minority Education, Vol. 3 No. 1.

Woo, Yen Yen Joyceln and J. A. Simmons. 2008. 'Paved with good intentions: images of textbook development in Afghanistan', Asia Pacific Journal of Education, Vol. 28, No. 3. 


\section{The Afghanistan Analyst}

Bibliography \#15

\section{Macro and Micro Economics}

Ali, Moharram and Adam Pain. 2004. 'Understanding Markets in Afghanistan: A Case Study of Carpets and the Andkhoy Carpet Market’, AREU. Download PDF.

Anderson, Erna and Amanda Sim. 2008. 'Microcredit, Informal Credit an Rural Livelihoods: A Village Case Study in Balkh Province’, AREU. Download PDF.

Andersen, Erna, Paula Kantor and Amanda Sim. 2008. 'Microcredit, Informal Credit and Rural Livelihoods: A Village Case Study in Bamyan Province’, AREU. Download PDF.

Azizi, Rohullah. 2010. 'The Economy of Afghanistan (An Overview of Opportunities and Risks of Doing Business in Afghanistan).’ Link to PDF.

Beall, Jo and Stefan Shütte. 2006. 'Urban Livelihoods in Afghanistan’, AREU. PDF.

Carnahan, Michael et al (eds.) 2004. Reforming Fiscal and Economic Management in Afghanistan. The World Bank.

Centlivres, Pierre. 1972. Un bazaar d'asie centrale: Forme et organization du bazaar de Tashqurghan. Wiesbaden: Luwig Reichart.

Centlivres, Pierre. 1976. 'Structure et evolution des bazaars du nord afghan', in Aktuelle probleme der Regionalentwicklung und Stadtgeographie Afghanistans, edited by Erwin groztbach. Meisenham am Glan: Anton Hain.

Chipchase, Jan and Panthea Lee. 2011. ‘Mobile Money: Afghanistan’, IMTFI. PDF.

Ciarli, Tommaso, et al. 2010. 'Conflict and Entrepreneurial Activity in Afghanistan: Findings from the National Risk Vulnerability Assessment Data', United Nations University. Download PDF.

Ciarli, Tommaso. 2009. 'Conflict and Entrepreneurial Activity in Afghanistan: Findings from the National Risk Vulnerability Assessment data', UNU-WIDER Project Workshop on Entrepreneurship and Conflict. INCORE, University of Ulster. Download PDF.

Coburn, Noah. 2008. 'Qaum: Conceptualizing Potters in the Afghan Political Arena', Boston University. Download PDF.

Coyne, C. J. and Adam Pellillo. 2011. 'Economic reconstruction amidst conflict: Insights from Afghanistan and Iraq’, Defence and Peace Economics, February 2011. 
Cusack, Jake and Erik Malmstrom. 2011. 'Bactrian Gold: Challenges and Hope for Private-Sector Development in Afghanistan’, Kauffman Foundation Research Series: Expeditionary Economics. Download PDF.

Danspeckgruber, W. and R. Finn. 2007. 'The Afghan Economy', in Building State and Security in Afghanistan. W. Danspeckgruber (ed.). Woodrow Wilson School. PDF.

D'Souza, Anna E. and Dean Jolliffe. 2010. 'Rising Food Prices and Coping Strategies: Household-Level Evidence from Afghanistan’, World Bank Policy Research Working Paper Series. Link to PDF.

Favre, Raphy. 2004. 'Market Development, Location of Bazaars and Road Network Conditions in Afghanistan', AIZON publication, Kabul. Download PDF.

Fry, Maxwell J. 1974. The Afghan economy: money, finance, and the critical constraints to economic development. Leiden: Brill.

Ghani, Ashraf. 1982. Production and Domination: Afghanistan, 1747-1901. Ph.D. disssertation, Columbia University.

Glaubitt, K., F. Saadeddin and B. Schäfer.1977. 'Government revenues and economic development of Afghanistan’, Afghanistan Journal, Vol. 4, Issue 1, pp. 20-25.

Grace, J. and A. Pain. 2004. 'Rethinking Rural Livelihoods in Afghanistan', AREU. PDF.

Grace, Jo. 2003. 'One Hundred Households in Kabul: A Study of Winter Vulnerability', AREU. Download PDF.

Hanifi, Mohammed Jamil. 1976. 'Preindustrial Kabul: its structure and function in transformational processes in Afghanistan', in The mutual interaction of people and their built environment: a cross-cultural perspective. Ed. Amos Rapoport. Mouton.

Hamed, Menhajuddin. 2007. The role of microfinance sector in eliminating poverty in Afghanistan: a pragmatic legal perspective. Thesis (LL. M.)--University of Washington.

Harvey, Michael David. 2006. Microfinance in postwar Afghanistan: towards a conflictsensitive approach. Thesis (M. Phil.)--Massey University, New Zealand.

Hayaud-Din, Mian Ahad. 2003. 'The Hawallah network: culture and economic development in Afghanistan', International Social Science Review, Vol. 78, No. 1/2.

Hunte, Pamela and Anastasiya Hozyainova. 2008. 'Factors Influencing Decisions to Use Child Labour: A Case Study of Poor Households in Rural Badakhshan’, AREU. PDF.

Hunte, Pamela. 2004. 'Some Notes on the Livelihoods of the Urban Poor in Kabul, Afghanistan’, AREU. Download PDF. 
Kantor, Paula and Adam Pain. 2011. 'Running out of Options: Tracing Rural Afghan Livelihoods’, AREU. Download PDF.

Kantor, Paula. 2010. 'Improving Efforts to Achieve Equitable Growth and Reduce Poverty’, AREU. Download PDF.

Kantor, Paula and Erna Andersen. 2010. 'Building a Viable Microfinance Sector in Afghanistan', AREU. Download PDF.

Kantor, Paula and Adam Pain. 2010. 'Securing Life and Livelihoods in Rural Afghanistan: The Role of Social Relationships, AREU. Download PDF.

Kantor, Paula. 2010. 'Poverty in Afghan Policy: Enhancing Solutions through Better Defining the Problem', AREU. Download PDF.

Kantor, Paula. 2009. 'From Access to Impact: Microcredit and Rural Livelihoods in Afghanistan’, AREU. Download PDF.

Kantor, Paula. 2008. 'Diversification and security? Labour mobilization among urban poor households in Kabul, Afghanistan’, Habitat International, Vol. 32, pp. 248-260.

Kantor, Paula, Adam Pain, et al. 2009. 'Delivering on Poverty Reduction: Focusing ANDS Implementation on Pro-Poor Outcomes', AREU. Download PDF.

Kantor, Paula and Erna Andersen. 2007. 'Microcredit, Informal Credit and Rural Livelihoods: A Village Case Study in Kabul Province’, AREU. Download PDF.

Kantor, Paula and Stefan Schutte. 2007. 'Create more quality jobs with regular pay to improve livelihoods and political stability’, AREU. Download PDF.

Klijn, Floortje and Adam Pain. 2007. 'Finding the Money: Informal Credit Practices in Rural Afghanistan’, AREU. Download PDF.

Lister, Sarah and Tom Brown with Zaineddin Karaev. 2004. 'Understanding Markets in Afghanistan: A Case Study of the Raisin Market’, AREU. Download PDF.

Lister, Sarah and Zaineddin Karaev. 2004. 'Understanding Markets in Afghanistan: A Case Study of the Market in Construction Materials’, AREU. Download PDF.

Maimbo, Samuel Munzele. 2003. The Money Exchange Dealers of Kabul: A Study of the Hawala System in Afghanistan. Washington DC: World Bank.

Malmstrom, Erik and Jake Cusack. 2010. ‘Afghanistan’s Willing Entrepreneurs: Supporting Private-Sector Growth in the Afghan Economy’, CNAS. Download PDF. 
Michel, Aloys Arthur. 1959. The Kabul, Kunduz and Helmand Valleys in the National Economy of Afghanistan. Washington: National Research Council. Link to PDF.

Michel, Aloys Arthur. 1960. The Kabul, Kunduz, and Helmand Valleys and the National Economy of Afghanistan. Ph.D. dissertation, Columbia University.

Mansfield, David and Adam Pain. 2005. 'Alternative Livelihoods: Substance or Slogan?', AREU. Download PDF.

Naseh, Wali Mohammad. 2007. The role of the investment law in the improvement of the Afghanistan investment climate: analysis of the effectiveness of the 2005 investment law and the Afghanistan Investment Support Agency. Thesis--University of Washington.

Nezami, Batul and Paula Kantor. 2010. 'Afghanistan Livelihood Trajectories: Evidence from Faryab’, AREU. Download PDF.

Pain, Adam and Paula Kantor. 2011. 'Beyond the Market: Can the AREDP transform Afghanistan's rural nonfarm economy?’, AREU. Download PDF.

Pain, Adam. 2010. 'Afghanistan Livelihood Trajectories: Evidence from Kandahar', AREU. Download PDF.

Pain, Adam. 2010. 'Afghanistan Livelihood Trajectories: Evidence from Badakhshan', AREU. Download PDF.

Pain, Adam and Alice Kerr-Wilson. 2003. 'Three Villages in Alingar, Laghman: Understanding Rural Livelihoods’ AREU. Download PDF.

Pain, Adam and Sarah Lister. 2004 'Trading in Power: The Politics of "Free” Markets in Afghanistan’, AREU. Download PDF.

Pain, Adam and S. Lautze. 2002. ‘Addressing Livelihoods in Afghanistan’, AREU. $\underline{\text { PDF. }}$

Parto Saeed and Ashkay Regmi. 2009. 'Microcredit and Reconstruction in Afghanistan: An Institutionalist Critique of Imported Development', in Institutional Analysis and Praxis: The Social Fabric Matrix Approach. Tara Natarajan et al (eds.). NY: Springer.

Parto, Saeed et al 2007. 'Enabling or Disabling? The Operating Environment for Small and Medium Enterprises in Rural Afghanistan’, AREU. Download PDF.

Paterson, Anna. 2006. 'Putting the Cart Before the Horse? Privatisation and Economic Reform in Afghanistan', AREU. Download PDF.

Paterson, Anna. 2006. 'Going to Market: Trade and Traders in Six Afghan Sectors', AREU. Download PDF. 
Paterson, Anna. 2005. 'Understanding Markets in Afghanistan: A Study of the Market for Pharmaceuticals', AREU. Download PDF.

Paterson, Anna. 2005. 'Understanding Markets in Afghanistan: A Study of the Market for Second-hand Cars', AREU. Download PDF.

Paterson, Anna. 2005. 'Understanding Markets in Afghanistan: A Study of the Market for Petroleum Fuels’, AREU. Download PDF.

Pavlovic, Jelena and Joshua Charap. 2009. 'Development of the Commercial Banking System in Afghanistan: Risks and Rewards’, IMF. Download PDF.

Schütte, S. 2006. 'Poverty Amid Prosperity: Urban Livelihoods in Herat', AREU. $\underline{\text { PDF. }}$

Schütte, S. 2006. 'Gaining Some Ground: Urban Livelihoods in Jalalabad’, AREU. PDF.

Schütte, S. 2006. 'Searching for Security: Urban Livelihoods in Kabul’, AREU. PDF.

Schütte, Stefan. 2006. 'Dwindling Industry, Growing Poverty: Urban Livelihoods in Pule Khumri', AREU. Download PDF.

Schütte, Stefan. 2006. 'Poor, Poorer, Poorest: Urban Livelihoods and Vulnerability in Mazari-Sharif', AREU. Download PDF.

Schütte, Stefan. 2005. 'Emerging Trends in Urban Livelihoods', AREU. Download PDF.

Schütte, Stefan. 2005. 'Livelihoods of the Urban Poor: Conceptional Issues and Review of Literature’, AREU. Download PDF.

Schütte, Steffan. 2004. 'Urban Vulnerability in Afghanistan: Case Studies from Three Cities', AREU. Download PDF.

Shaw, Tom. 2010. ‘Afghanistan Livelihood Trajectories: Evidence from Sar-i-Pul', AREU. Download PDF.

Sim, Amanda and Marie-Louise Hoilund-Carlsen. 2008. 'Factors Influencing Decisions to Use Child Labour: A Case Study of Poor Households in Heart', AREU. PDF.

Thompson, Edwina A. 2011. Trust is the Coin of the Realm: Lessons from the Money Men in Afghanistan. Oxford University Press.

Van Liere, Adam. 2011. 'Afghanistan's Accession into the World Trade Organization', Western Political Science Association 2011 Annual Meeting. Link.

World Bank. 2009. 'Afghanistan Investment Climate in 2008.’ Download PDF. 
World Bank. 2009. 'Finance and Security in Afghanistan.’ Download PDF.

Wright, P. 1981. 'An account of the production of bricks in the Kabul Region during the late 1970's and early 1980's', Afghanistan Journal, Vol. 8, Issue 4, pp. 132-137.

Yarash, Nasratullah and Katja Mielke. 2011. 'The Social Order of the Bazaar: Socioeconomic embedding of Retail and Trade in Kunduz and Imam Sahib’, ZEF Working Paper Series, No. 79. Download PDF.

Yarash, Nasratullah et al. 2010. 'The fuel economy of mountain villages in Ishkamish and Burka (Northeast Afghanistan): Rural subsistence and urban marketing patterns', ZEF Working Paper Series, No. 73. Download PDF.

Zand, Sogol. 2010. 'The Impact of Microfinance Programmes on Women's Lives: A Case Study in Parwan Province', AREU. Download PDF. 


\section{Public Opinion: Interviews, Study Groups, Polls and Surveys}

\section{Sorted by date:}

UNDP. 2011. 'Afghanistan Police Perception Survey 2010', United Nations Development Programme // Afghan Center for Socio-Economic and Opinion Research. Download PDF.

ABC/BBC/ARD/Washington Post. 2010. 'Afghanistan: Where things stand', 6 December 2010. Download PDF.

Asia Foundation. 2010. 'Afghanistan in 2010: A Survey of the Afghan People.’ PDF.

Integrity Watch Afghanistan. 2010. 'Afghan Perceptions and Experience of Corruption A National Survey.’ Download PDF.

Zabih Ullah. 2010. 'A view from Kandahar: How Afghans View Coalition Military Operations in Kandahar', Lowy Institute. Link to PDF.

ABC-ARD-BBC. 2010 (January). 'ABC News/BBC/ARD Poll: Afghanistan - where things stand.' Download PDF.

Asia Foundation. 2009. 'Afghanistan in 2009: A Survey of the Afghan People', The Asia Foundation’s fifth public opinion poll in Afghanistan. Download PDF.

Oxfam. 2009. 'The Cost of War: Afghan Experiences of Conflict, 1978-2009.’ PDF.

IRI. 2010. 'Afghanistan Post-Election Survey: November 16 - 25, 2009’, International Republican institute. Link to multiple PDFs.

IRI. 2009. 'Afghanistan Public Opinion Survey’, International Republican Institute. July, 2009. Download PDF.

IRI. 2009. 'Afghanistan Public Opinion Survey', International Republican Institute. May, 2009. Download PDF.

Cordesman, Anthony H. 2009. 'Afghan Public Opinion and the Afghan War: Shifts by Region and Province’, CSIS. Download PDF.

ICRC. 2009. 'Afghanistan: Opinion Survey 2009: The Impact of Conflicts and Armed Violence on Civilians’, International Committee of the Red Cross. Download PDF. 
ABC/BBC/ARD. 2009. 'Afghanistan: Where Things Stand', ABC/BBC/ARD Poll. Download PDF.

Langer, Gary. 2009. 'Public Opinion Trends in Afghanistan', CSIS. Download PDF.

Rennie, Ruth (ed.). 2008. State Building, Security, and Social Change in Afghanistan: Reflections on a Survey of the Afghan People', The Asia Foundation. Download PDF.

Asia Foundation. 2008. 'Afghanistan in 2008: A Survey of the Afghan People', Asia Foundation. Download PDF.

D3 Systems. 2008. 'Afghanistan Media Survey: Report Prepared for BBC Trust', D3 Systems / Afghan Center for Social and Opinion Research / BBC Trust. Download PDF.

BBC/ABC/ARD Public Opinion Poll. December 3, 2007. Download PDF.

Environics/Canadian Broadcasting Corporation. 2007. 'Poll: What Afghans Think.' PDF.

Asia Foundation. 2007. 'A Survey of the Afghan People.' Download PDF.

Gardizi, Manija. 2007. ‘Afghans’ Experience of Corruption: A study Across Eight Provinces', Integrity Watch Afghanistan. Link to PDF.

Asia Foundation. 2006. 'A Survey of the Afghan People.' Download PDF.

Weber, Stephen et al. 2006. 'Afghan Public Opinion Amidst Rising Violence’, A WorldPublicOpinion.org Poll. December 14, 2006. Fielded by D3 Systems and Afghan Center for Social and Opinion Research in Kabul. Download PDF.

Program on International Policy Attitudes (University of Maryland) / D3 Systems / Afghan Center for Social and Opinion Research, Kabul: "Poll of Afghanistan.” January 11, 2006 .

ABC News Poll. ‘Life in Afghanistan’, December 7, 2005. Download PDF.

The Clingendael Institute, Department For International Development: "Media, Public Opinion, and Peace Conditionalities in Post-Conflict Afghanistan -A study into local views on donor behaviour." The Netherlands, December 2005. Download PDF.

Center for Strategic and International Studies. 'In the Balance: Measuring Progress in Afghanistan', July 2005. Download PDF.

Human Rights Research and Advocacy Consortium (HRRAC). 'Take the Guns Away: Afghan Voices on Security and Elections', September 2004. Download PDF. 
Asia Foundation / Afghan Media Resource Center. ‘Democracy In Afghanistan', July 13, 2004. Download PDF.

National Democratic Institute of International Affairs. 'A Society in Transition: Focus

Group Discussions in Afghanistan’, December 2003. Download PDF.

Human Rights Research and Advocacy Consortium (HRRAC): "Speaking Out: Afghan Opinions on Rights and Responsibilities." November 2003. Download PDF.

National Democratic Institute of International Affairs. 'Afghan Perspectives on Democracy: A Report on Focus Groups in the Kabul Area on the Eve of the Emergency Loya Jirga', May 2002. Download PDF.

Center for Economic and Social Rights. 'Human Rights and Reconstruction in Afghanistan’, May 2002. Download PDF. 


\section{The Afqhanistan Analyst}

Bibliography \#17

\section{Academic journals and periodicals}

The descriptions for these journals has been taken from the Arthur Paul Afghanistan Collection Bibliography - Volume II: English and European Languages (2000) by Shaista Wahab and refers to their holdings. Download this bibliography in PDF.

Note: None of these journals are available online. Search Worldcat to find a library where these journals are located: http://www.worldcat.org/advancedsearch

\section{In alphabetic order:}

Afghan Information Centre Monthly Bulletin, (1980?-1992). Peshawar, Pakistan: Afghan Information Centre. Monthly. Title history: Monthly bulletin: Afghan Information Centre, no. 9 (Jan. 1982)- no. 24 (Mar. 1983); beginning no. 25 (Apr. 1983): Afghan Information Centre monthly bulletin. -- Reports on current situation in Afghanistan.

Afghanica, (1987-) Oxford, United Kingdom. Semiannual. Alternative title: Afghanistan studies newsletter. Afghanistan studies newsletter; editor: (March 1989-) Jadwiga Pstrusinka. The main objective of this publication is to establish a link between scholars interested in Afghanistan and to inform them of the current conferences, projects, publications, and other scholarly activities in the field of Afghanistan studies.

Afghanistan, v. 1 (1946-1985) Kabul, Afghanistan: Historical Society of Afghanistan. Quarterly. In English and French. Volumes 1-2 in English; v. 3 - in French and English. Issued July/Sept. 1946 - 1953 by the Press Dept.; Oct./Dec. 1953 - by the Director generale des relations culturelles; (winter 1982-) by the Scientific and Research Center, Afghanistan Academy of Sciences. Suspended after publication of v. 37, fall/winter 1984-1985. Includes articles on historical and cultural aspects of Afghan society. Articles are contributed by prominent national and international scholars.

Afghanistan forum, (1968?-1997) New York: Afghanistan Council, Asia Society. Bimonthly. Title history: Afghanistan newsletter, 1968 - fall 1973; newsletter Afghanistan Council, v. 2, no. 1 (spring 1974) - v. 10, no. 3 (June 1982); Afghanistan newsletter, v. 10, no. 4 (Oct. 1982); Afghanistan Forum newsletter, v. 11, no. 1 - v. 12, no. 1 (Jan. 1984); Afghanistan Forum, v. 12, no. 2 (Mar. 1984)-. Includes news clippings on the current Afghan situation. Ceased effective v. 25, no. 4, 1997.

Afghanistan info, (1979?-) Schweizerisches Komittee zur Unterstutzung des afghanischen Volkes = Comite Suisse de soutien au peuple afghan $=$ Commitato Svizzero di sostegno per il popolo afgano. Neuchatel: Comite Suisse de soutien au peuple afghan. Publishes twice yearly. In French and English. 
Afghanistan journal, (1974-) Graz, Akademische Druck - u. Verlagsanstalt. Issued in cooperation with Arbeitsgemeinschaft Afghanistan. Alternative title:

Arbeitsgemeinschaft Afghanistan. In German, English or French. Published articles on historical and cultural aspects of Afghan life.

Afghanistan news, (1957?-?) London: Information Bureau, Royal Afghan Embassy Monthly. Economics, social, cultural, historical, and political activities of Afghanistan.

Afghanistan-Nytt, (1979-?) Stockholm: Svenska Afghanistankommitten. In Swedish. Covers news and information regarding the political situation in Afghanistan and the Afghan refugees.

Afghanistan report, (1984-) Islamabad, Pakistan: Crisis and Conflict Analysis Team, Institute of Strategic Studies. Quarterly. Scholarly publication of the Institute of Strategic Studies; publishes articles on Afghanistan's history, political, social, and economic developments. Alternative title: Report on Afghanistan.

Afghanistan studies journal, (1988-) Omaha, Nebraska: University of Nebraska at Omaha, Center for Afghanistan Studies. Irregular. Promotes scholarly activities pertaining to Afghanistan; includes articles on Afghanistan's historical, cultural, political, social and educational activities.

Les Nouvelles d'Afghanistan, (1980-) Paris: Afrane. In French. Bimonthly publication. Supplements accompany some issues. 


\title{
The Afghanistan Analyst Law Bibliography
}

\author{
2nd Edition - June 2011 \\ Compiled by: Timothy Mathews \\ Juris Doctor, 2011 \\ University of Maine School of Law \\ timothy.mathews@maine.edu
}

\section{$\underline{\text { Table of Contents }}$}

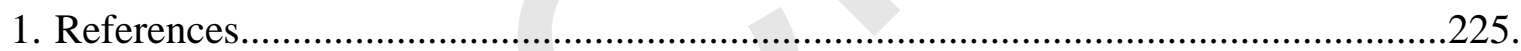

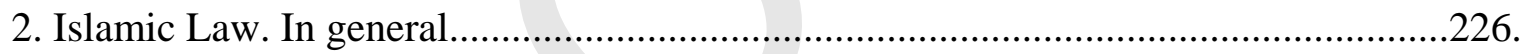

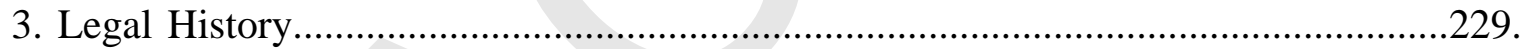

3.1 In General

3.2 Customary Law

3.3 Islamic Law

3.4 State Law

4. Constitutional Law

233.

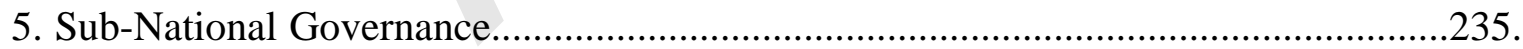

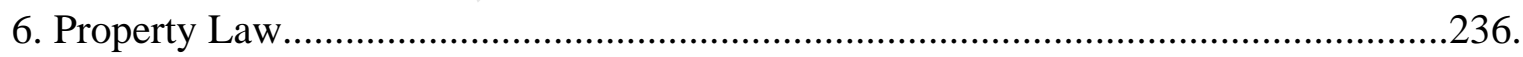

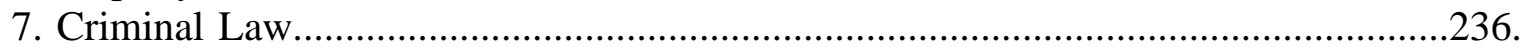

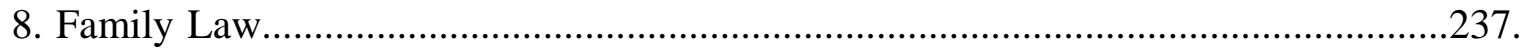

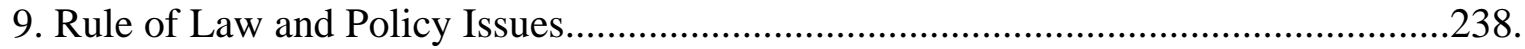




\section{The Afghanistan Analyst Law Bibliography Introduction}

This bibliography is intended to be an up-to-date resource for legal study and research pertaining to modern Afghanistan (1747 and later). Many sources are only available through legal search engines, such as Westlaw and Lexis-Nexis, or through academic databases such as JSTOR, ProQuest, EBSCO, or HeinOnline. Hyperlinks are provided to sources that are freely available. For books, hyperlinks are provided to Google Books because this often offers a free preview and multiple options to purchase the book if one cannot be obtained from a nearby library.

Most articles herein that discuss comparative law have a common law audience in mind. This should not be problematic for readers with civil law backgrounds. Afghanistan borrows heavily from the civil law tradition, so the learning curve is not as steep as it is for readers educated in common law jurisdictions.

Hyperlinks to Google Books are not an endorsement of any merchants listed by Google Books. With all hyperlinks, care has been taken to only link to sites that are not malicious and that post materials that appear to be lawful and comply with copyright laws. However, websites occasionally change owners, rename files, or are targeted by malicious hackers. Users of this bibliography assume all risk when clicking on links to third-party sites.

Recommendations are welcome regarding the organization of this bibliography and inclusion (or exclusion) of any sources. I also welcome hyperlinks that I have inadvertently omitted to sources listed herein which are available online. Send suggestions to: timothy.mathews@maine.edu or contact@afghanistan-analyst.org.

Timothy Mathews Portland, Maine, USA. 


\section{References.}

Research tools and items other than articles, books, and reports that are in database or encyclopedia format.

\section{$\underline{\text { References }}$}

Family Structures and Family Law in Afghanistan (Max Planck Institute for Foreign Private Law and Private International Law 2005), available at mpipriv.de.

Conor Foley, A Guide to Property Law in Afghanistan (First Edition), Norwegian Refugee Council (Sep., 2005). internal-displacement.org.

Alexandra H. Guhr, Ramin Moschtaghi \& Mandana Knust Rassekh Afshar, Max Planck Manual on Fair Trial Standards in the Afghan Constitution, the Afghan Interim Criminal Code for Courts, the Afghan Penal Code and other Afghan Laws as well as in the International Covenant on Civil and Political Rights (Max Planck Institute for Comparative Public Law and International Law, 4th ed. 2009), available at mpil.de.

International Legal Foundation, The Customary Laws of Afghanistan, September 2004. usip.org.

Omar Sial \& Md. Ershadul Karim, Islamic Republic of Afghanistan Legal System and Research, NYU Law, Hauser Global Law School Program (2010), available at nyulawglobal.org.

Stanford Law School, An Introduction to the Law of Afghanistan (Second Edition), Afghanistan Legal Education Project (2009). afghanistanlegaleducation.com.

\section{$\underline{\text { Resources }}$}

Afghan Legal Information Institute, Afghan Laws, at asianlii.org.

NYU Libraries, Afghanistan Digital Library, at afghanistandl.nyu.edu.

International Islamic University Malaysia, at lib.iiu.edu.my. 


\section{The Afghanistan Analyst}

Law Bibliography \#2

\section{Islamic Law. In general.}

Note: The focus of this section is to provide sufficient background information about Islamic law to put Hanafi fiqh, as practiced in Afghanistan, into context. This includes books of a general nature and law review articles that discuss specific issues.

\section{$\underline{\text { Books }}$}

NoAh Feldman, The Fall And Rise of the Islamic State (Princeton University Press 2008), available at Google Books.

WAEL HALlaQ, An InTRODUCTION TO IsLAMic LAW (Cambridge University Press 2009), available at Google Books.

Wael HallaQ, Authority, Continuity, And Change in Islamic Law (Cambridge University Press 2001), available at Google Books.

MAJid KhadDURI, The Islamic LAW OF NATIONS: SAYBAni's SiYAR (Johns Hopkins Press 1966), available at Google Books.

CHRistopher MELCHERT, THE FORMATION OF THE SUNNI SCHOOLS OF LAW, 9TH-10TH CENTURIES C.E. (Brill 1997), available at Google Books.

\section{$\underline{\text { Articles }}$}

Shaheen Sardar Ali, Resurrecting Siyar Through Fatwas? (Re) Constructing 'Islamic International Law' in a Post-(Iraq) Invasion World, 14 J. CONFLICT \& SECURITY L. 115 (2009).

Larry Catá Backer, Theocratic Constitutionalism: An Introduction to a New Global Legal Ordering, 16 InD. J. GLOBAL LEGAL STUD. 85 (2009).

M. Cherif Bassiouni \& Gamal M. Badr, The Shari'ah: Sources, Interpretation, and RuleMaking, 1 UCLA J. IsLAMIC \& NEAR E. L. 135 (2002), available at jay.law.ou.edu.

M. Cherif Bassiouni, Gamal M. Badr, Saad El-Fishawy, Farooq A. Hassan \& Erik Peterson, Contracts and Litigation in Islamic Law: The Sources of Islamic Law, 76 AM. SOC’Y INT’L L. PROC. 55 (1982).

Mohamed Abdel Dayem, In the Path of Allah: Evolving Interpretations of Jihad and Its Modern Challenges, 7 UCLA J. IsLAMIC \& NEAR E. L. 67 (2009). 
Bernard K. Freamon, Slavery, Freedom, and the Doctrine of Consensus in Islamic Jurisprudence, 11 HARV. HuM. RTS. J. 1 (1998), available at papers.ssrn.com.

Nicholas Garces, Islam, Till Death Do You Part? Rethinking Apostasy Laws Under Islamic Law and International Legal Obligations, 16 SW. J. INT’L L. 229 (2010).

Nazeem MI Goolam, Ijtihad and Its Significance for Islamic Legal Interpretation, 2006 Mich. ST. L. REV. 1443 (2006), available at msulawreview.org.

Adham A. Hashish, Ijtihad Institutions: The Key to Islamic Democracy Bridging and Balancing Political and Intellectual Islam, 9 RicH. J. GLOBAL L. \& Bus. 61 (2010).

Walid Iqbal, Dialogue and the Practice of Law and Spiritual Values: Courts, Lawyering, and ADR: Glimpses into the Islamic Tradition, 28 FORDHAM URB. L.J. 1035 (2001).

Liaquat Ali Khan, Jurodynamics of Islamic Law, 61 RUTGERS L. REV. 231 (2009), available at papers.ssrn.com.

Almas Khan, The Interaction Between Shariah and International Law in Arbitration, 6 CHI. J. INT’L L. 791 (2006).

Faisal Kutty, The Shari'a Factor in International Commercial Arbitration, 28 LoY. L.A. INT'L \& COMP. L. REV. 565 (2006), available at ilr.lls.edu.

Herbert J. Liebesny, Judicial Systems in the Near and Middle East: Evolutionary Development and Islamic Revival, 37 MidDLE EAST J. 202 (1983).

Clark B. Lombardi \& Nathan J. Brown, Do Constitutions Requiring Adherence to Shari'a Threaten Human Rights? How Egypt's Constitutional Court Reconciles Islamic Law with the Liberal Rule of Law, 21 Am. U. INT'L L. REV. 379 (2006), available at auilr.org.

Jacqueline McCormack, Commercial Contracts in Muslim Countries of the Middle East: A Comparison with the United States, 37 INT'L J. LEGAL INFO. 1 (2009), available at scholarship.law.cornell.edu.

Kathleen A. Portuan Miller, Who Says Muslim Women Don't Have the Right to Divorce? - A Comparison Between Anglo-American Law and Islamic Law, 22 N.Y. INT'L L. REV. 201 (2009).

Asifa Quraishi, Who Says Shari'a Demands the Stoning of Women? A Description of Islamic Law and Constitutionalism, 1 BerK. J. MidDle E. \& IsLAMIC L. 163 (2008), available at cardozo.yu.edu.

Sadiq Reza, Islam's Fourth Amendment: Search and Seizure in Islamic Doctrine and Muslim Practice, 40 GEO. J. INT’L L. 703 (2009). 
Sadiq Reza, Torture and Islamic Law, 8 CHI. J. INT’L L. 21 (2007).

Tad Stahnke \& Robert C. Blitt, The Religion-State Relationship and the Right to Freedom of Religion or Belief: A Comparative Textual Analysis of the Constitutions of Predominantly Muslim Countries, 36 GEO. J. INT’L L. 947 (2005), available at papers.ssrn.com.

Frank Vogel, An Introduction to the Law of the Islamic World, 31 INT'L J. LEGAL INFO. 353 (2003).

Frank E. Vogel, The Trial of Terrorists Under Classical Islamic Law, 43 HARV. INT'L L.J. 53 (2002).

David A. Westbrook, Islamic International Law and Public International Law: Separate Expressions of World Order, 33 VA. J. INT’L L. 819 (1993).

Diana Zacharias, Fundamentals of the Sunni Schools of Law, 66 HeIDELBERG J. INT'L L. 491 (2006), available at zaoerv.de. 


\section{The Afghanistan Analyst Law Bibliography \#3}

\section{Legal History.}

\section{Discussions of the legal traditions in Afghanistan.}

\subsection{In General.}

Broad topics related to Afghan legal systems and legal history

\section{Books and Articles in Books}

MOHAMMAD HASHIM KAMALI, LAW IN AFGHANISTAN (E. J. Brill 1985), available at Google Books.

Ali Wardak, Structures of Authority and Local Dispute Settlement in Afghanistan in CONFlicts And Conflict Resolution in Middle EAstern SOCIETIES: Between TRADITION AND MODERNITY (Albrecht et al., eds., Duncker \& Humblot 2006), available at Google Books.

Ali Wardak, Jirga: Power and Traditional Conflict Resolution in Afghanistan in LAW After Ground Zero 187 (John Strawson, ed., Cavendish 2002), available at Google Books.

\section{$\underline{\text { Articles }}$}

Benjamin Buchholz, Thoughts on Afghanistan's Loya Jirga: A Myth?, ASIEN 104 (Juli 2007), S. 23-33, available at asienkunde.de.

Nafay Choudhury, Reconceptualizing Legal Pluralism in Afghanistan, 2010 WINDSOR REV. LEGAL \& SOC. ISSUES 21 (2010).

Bruce Etling, Legal Authorities in the Afghan Legal System (1964-1979), Harv. L. School: Islamic Legal Studies Program (2003), available at law.harvard.edu.

M. Jamil Hanifi, Editing the Past: Colonial Production of Hegemony Through the "Loya Jerga” in Afghanistan, 37 IRANIAN STUD. 295 (2004), available at farda.org.

Esther Meininghaus, Legal Pluralism in Afghanistan, University of Bonn, Amu Darya Series Paper No. 8 (Dec. 2007), available at zef.de.

Senzil Nawid, The State, the Clergy, and British Imperial Policy in Afghanistan during the $19^{\text {th }}$ and Early 20 ${ }^{\text {th }}$ Centuries, 29 InT. J. MiddLE EAST STUD. 581 (1997). 
Neamat Nojumi, Dyan Mazurana \& Elizabeth Stites, Afghanistan's Systems of Justice: Formal, Traditional, and Customary, (Tufts University 2004), available at gmu.edu.

Astri Suhrke \& Kaja Borchgrevink, Negotiating justice sector reform in Afghanistan, Crime, Law \& Social Change (2008), available at humansecuritygateway.com.

M. G. Weinbaum, Legal Elites in Afghan Society, 12 InT. J. MiddLE EAst STUD. 39 (1980).

Robert F. Williams, Legal Education in Afghanistan Prior to the Soviet Occupation, 6 SUFFOLK TRANSNAT’L L.J. 247 (1981-1982).

\subsection{Customary Law.}

Afghan customary law and dispute resolution

Thomas Barfield, Afghan Customary Law and Its Relationship to Formal Justice Institutions, United States Institute of Peace (2003), available at usip.org.

Thomas J. Barfield, Culture and Custom in Nation-Building: Law in Afghanistan, $60 \mathrm{ME}$. L. REV. 347 (2008).

Thomas J. Barfield, On Local Justice and Culture in Post-Taliban Afghanistan, 17 ConN. J. INT’L L. 439 (2002).

Noah Coburn \& John Dempsey, Informal Dispute Resolution in Afghanistan, United States Institute of Peace (2010), available at usip.org.

Gregory Day, Guns, Goats and Justice in Afghanistan, 67-OCT Or. St. B. Bull. 19 (2007).

John Dempsey and Noah Coburn, Traditional Dispute Resolution and Stability in Afghanistan, United States Institute of Peace (2010), available at usip.org.

Palwasha Kakar, Tribal Law of Pashtunwali and Women's Legislative Authority, Harv. L. School: Islamic Legal Studies Program (2003), available at law.harvard.edu.

Susanne Schmeidl and Masood Karokhail, The Role of Non-State Actors in 'CommunityBased Policing' - An Exploration of the Arbakai (Tribal Police) in South-Eastern Afghanistan, 30 CONTEMPORARY SECURITY POL'y 318 (2009), available at tloafghanistan.org.

Mohammed Osman Tariq, Tribal Security System (Arbakai) in Southeast Afghanistan, Crisis States Research Centre Occasional Paper no. 7 (2008), available at crisisstates.com. 
Lutz Rzehak, Doing Pashto: Pashtunwali as the ideal of honourable behavior and tribal life among the Pashtuns (Afghanistan Analysts Network 2011), available at aanafghanistan.org.

Amin Tarzi, Historical Relationship between State and Non-State Judicial Sectors in Afghanistan, United States Institute of Peace (October 2006), available at usip.org.

USAID, Field Study of Informal and Customary Justice in Afghanistan, Rule of Law Project (2005), available at usip.org.

Nadjma Yassari \& Mohammad Hamid Saboory, Sharia and national law in Afghanistan, 6 J. OF PHILOSOPHY OF INT’L LAW AND GLOBAL POLITICS 1 (2010), available at juragentium.unifi.it.

\subsection{Islamic Law.}

Articles focusing on Islamic law as applied in Afghanistan, to include functioning of courts of Sharia

Hafizullah Emadi, The End of Taqiyya: Reaffirming the Religious Identity of Ismailis in Shughnan, Badakhshan - Political Implications for Afghanistan, 34 MIDDLE EASTERN STUD 103 (1998).

Ashraf Ghani, Disputes in a Court of Sharia, Kunar Valley, Afghanistan, 1885-1890, 15 INT. J. MidDLE EAST STUD. 353 (1983).

Martin Lau, Islamic Law and the Afghan Legal System, United Nations Public Administration Network, available at unpan1.un.org.

Kristin Mendoza, Islam and Islamism in Afghanistan, Harvard Law School: Islamic Legal Studies Program (2003), available at law.harvard.edu.

Ahmad Indrees Rahmani, The Role of Religious Institutions in Community Governance Affairs: How are Communities Governed Beyond the District Level? (Central European University 2006).

Olivier Roy, Rivalries and Power Plays in Afghanistan: The Taliban, the Shari'a and the Pipeline, 202 MiddLE EAST REPORT 37 (1996).

\subsection{State Law.}

State law and functioning of state courts 


\section{$\underline{\text { Articles }}$}

Livingston Armytage, Justice in Afghanistan: Rebuilding Judicial Competence After the Generation of War, 67 HEIDELBERG J. OF INT’L L. 185 (2007), available at zaoerv.de.

Martin Lau, Afghanistan's Legal System and its Compatibility with International Human Rights Standards, International Commission of Jurists (2004), available at unhcr.org. Katherine McCullough, Out With the Old and In With the New: The Long Struggle for Judicial Reform in Afghanistan, 19 GEO. J. LEGAL ETHICS 821 (2006).

Ramin Moschtaghi, Organisation and Jurisdiction of the Newly Established Afghan Courts - The Compliance of the Formal System of Justice with the Bonn Agreement, 10 Max Planck Yearbook of United Nations Law 531 (2006).

Barnett R. Rubin, Lineages of the State of Afghanistan, 28 ASIAN SURVEY 1188 (1988).

\section{Other}

Regulation of Judicial Conduct for the Judges of the Islamic Republic of Afghanistan (Training Course) (USAID 2007), available at afghantranslation.checchiconsulting.com. 


\section{The Afghanistan Analyst}

Law Bibliography \#4

\section{Constitutional Law.}

\section{Articles and reports discussing Afghan constitutional law, constitutional drafting, and related issues}

Katharine Adeney, Constitutional Design and the Political Salience of "Community" Identity in Afghanistan, 48 ASIAN SURVEY 535 (2008).

Afghanistan’s Flawed Constitutional Process (International Crisis Group, 2003), available at merln.ndu.edu.

Said Amir Arjomand, Constitutional Developments in Afghanistan: A Comparative and Historical Perspective, 53 DraKe L. REV. 943 (2005).

Michele Brandt, Constitutional Assistance in Post-Conflict Countries: The UN Experience: Cambodia, East Timor \& Afghanistan, United Nations Development Programme (June 2005), available at unrol.org.

Nusrat Choudhury, Constrained Spaces for Islamic Feminism: Women's rights and the 2004 Constitution of Afghanistan, 19 YALE J.L. \& FEMINISM 155 (2007).

John Dempsey \& J. Alexander Their, Resolving the Crisis over Constitutional Interpretation in Afghanistan, (United States Institute of Peace 2009).

Justin Desautels-Stein, Bolstering Democracy in Iraq, Afghanistan, and Kyrgyzstan: Rites and Rights in Afghanistan: The Hazara and the 2004 Constitution, 29 FletCHER F. WORLD AFF. 157 (2005).

Andrew Finkelman, The Constitution and Its Interpretation: An Islamic Perspective on Afghanistan's Constitutional Development Process, 2002-2004, Al Nakhlah, Article 2 (2005).

Rainer Grote, Separation of Powers in the New Afghan Constitution, 64 HiEDELBERG J. OF INT’L L. 897 (2004), available at zaoerv.de.

Chris Johnson, William Maley, Alexander Their \& Ali Wardak, Afghanistan's Political and Constitutional Development (ODI/DFID: London 2003), available at odi.org.uk.

Muhammad Hashem Kamali, References to Islam and Women in the Afghan Constitution, 22 ARAB L. Q. 270 (2008). 
Martin Lau, The Independence of Judges Under Islamic Law, International Law and the New Afghan Constitution, 64 HeIDELBERG J. OF INT’L L. 917 (2004), available at zaoerv.de.

Said Mahmoudi, The Sharia in the New Afghan Constitution: Contradiction or Compliment?, 64 HEIDELBERG J. OF INT’L L. 867 (2004), available at zaoerv.de.

Barnett R. Rubin, Crafting a Constitution of Afghanistan, 15 J. OF DEMOCRACY 5 (2004), available at cic.nyu.edu.

Michael Schoiswohl, Linking the International Legal Framework to Building the Formal Foundations of a "State at Risk": Constitution-Making and International Law in PostConflict Afghanistan, 39 VAND. J. TRANSNAT’L L. 819 (2006).

Michael Schoiswohl, The New Afghanistan Constitution and International Law: A LoveHate Affair, 4 INT'L J. CONST. L. 664 (2006).

J. Alexander Thier, The Making of a Constitution in Afghanistan, 51 N.Y.L. SCH. L. REV. 557 (2007), available at nyls.edu. 


\section{The Afghanistan Analyst}

Law Bibliography \#5

\section{Sub-National Governance.}

Items discussing Provincial, Municipal, District, and Village level governance, with emphasis upon dispute resolution and other means in which law is applied

An Evaluation of the Khost Commission on Conflict Mediation, (The Liaison Office 2009), available at tlo-afghanistan.org.

Thomas J. Barfield, Informal Dispute Resolution and the Formal Legal System in Contemporary Northern Afghanistan (Draft Report), United States Institute of Peace (April 21, 2006), available at usip.org.

Thomas Barfield \& Neamatollah Nojumi, Bringing More Effective Governance to Afghanistan: 10 Pathways to Stability, 17 MidDle EAst POLICY 40 (2010).

Thomas J. Barfield, Neamat Nojumi \& J. Alexander Thier, The Clash of Two Goods: State and Non-State Dispute Resolution in Afghanistan, United States Institute of Peace (2006), available at usip.org.

Linkages Between State and Non-State Justice Systems in Eastern Afghanistan (The Liaison Office 2009), available at tlo-afghanistan.org.

René El Saman, Linking formal and informal conflict resolution mechanisms in Afghanistan (Sanayee Development Organization 2008), available at library.fes.de.

Marika Theros \& Mary Kaldor, Building Afghan Peace From the Ground Up (The Century Foundation 2011), available at tcf.org.

United States Institute of Peace, Between the Jirga and the Judge (2009), available at usip.org. 


\section{The Afghanistan Analyst}

Law Bibliography \#6

\section{Property Law}

J. David Stansfield, Yasin Safar \& Akram Salam, Community-State Administration of Private Property Records in Rural Afghanistan, Terra Institute LTD. (2008), available at iasc2008.glos.ac.uk.

Islamic Republic of Afghanistan: Capacity Building for Land Policy and Administration Reform (Asian Development Bank 2009), available at adb.org.

\section{The Afghanistan Analyst}

\section{Criminal Law}

\section{Primary source documents}

1965 Criminal Procedure Law (amended 1974), available at mpil.de.

1969 Law of Prohibition of Smuggling, available at mpil.de.

1972 Law for the Prosecution and Punishment of Bribery, available at mpil.de.

1976 Penal Code (October 17, 1976), available at mpil.de.

\section{$\underline{\text { Articles }}$}

Cynthia Alkon, The Increased Use of "Reconciliation" in Criminal Cases in Central Asia: A Sign of Restorative Justice or Cause for Concern?, 8 PEPP. DiSP. RESOL. L.J. 41 (2007).

Faiz Ahmed, Judicial Reform in Afghanistan: A Case Study in the New Criminal Procedure Code, 29 HASTINGS INT’L \& COMP. L. REV. 93 (2005).

Silvia Tellenbach, Fair Trial Guarantees in Criminal Proceedings Under Islamic, Afghan Constitutional, and International Law, 64 HeIDELBERG J. OF INT’L L. 929 (2004) , available at zaoerv.de. 


\section{The Afghanistan Analyst}

\section{Family Law}

\section{Primary Source Documents}

1949 Law of Mourning Ceremonies, available at mpipriv.de.

1949 Law of Weddings, Marriage, and Circumcision, available at mpipriv.de.

1971 Marriage Law, available at mpipriv.de.

\section{$\underline{\text { Reports }}$}

Harmful Traditional Practices and Implementation of the Law on Elimination of Violence against Women in Afghanistan (UNAMA 2009), available at unama.unmissions.org.

Orzala Ashraf Nemat, Comparative Analysis of Family Law in the Context of Islam (Heinrich Boell Foundation 2006), available at boell-afghanistan.org. 


\section{The Afqhanistan Analyst}

Law Bibliography \#9

\section{Rule of Law and Policy Issues}

\section{Post-conflict reconstruction, transitional justice}

Faiz Ahmed, Afghanistan's Reconstruction, Five Years Later: Narratives of Progress, Marginalized Realities, and the Politics of Law in a Transitional Islamic Republic, 10 GONZ. J. INT’L L. 269 (2006-2007).

Tanya Domenica Bosi, U.N. Report: Post-Conflict Reconstruction: The United Nations Involvement in Afghanistan, 19 N.Y.L. SCH. J. HuM. RTS. 819 (2003).

Christina Jones-Pauly, Neamat Nojumi, Balancing Relations Between Society and State: Legal Steps Toward National Reconciliation and Reconstruction of Afghanistan, 52 AM. J. COMP. L. 825 (2004), available at usip.org.

Sari Kouvo, Transitional Justice in the Context of Ongoing Conflict: the Case of Afghanistan, ICTJ Briefing, International Center for Transitional Justice (2009), available at ictj.org.

Sarah Lister, Understanding State-Building and Local Government in Afghanistan, Crisis States Research Centre, Working Paper no. 14 (2007), available at crisisstates.com.

William Maley, Democratic Governance and Post-Conflict Transitions, 6 CHI. J. INT’L L. 683 (2006).

Amin Saikal, Afghanistan's Transition: ISAF's stabilization role?, 27 THIRD WORLD QUARTERLY 525 (2006).

Epaminontas E. Triantafilou, In Aid of Transitional Justice: Eroding Norms of Revenge in Countries with Weak State Authority, 10 UCLA J. INT'L L. \& FOREIGN AFF. 541 (2005).

Ali Wardak, Building a post-war justice system in Afghanistan, 41 J. CRIME, LAW \& SOC. CHANGE 319 (2004), available at usip.org.

\section{Rule of Law}

Patricia Gossman, The Past as Present: War Crimes, Impunity and the Rule of Law, London School of Economics and Political Science and University of Bonn (Jun. 2003), available at eprints.lse.ac.uk.

Manual on Rule of Law: Afghanistan (Bar Human Rights Committee of England and Wales March 2006), available at barhumanrights.org.uk. 
Dr. Christine Noelle-Karimi, Local perceptions of state and law, Center for Development Research (2003), available at ag-afghanistan.de.

William H. Spencer, Securing the Rule of Law in Post-Taliban Afghanistan: Establishing the Rule of Law, 17 CONN. J. INT'L L. 445 (2002).

United States Institute of Peace, Establishing the Rule of Law in Afghanistan (2004), available at usip.org.

Ali Wardak, Daud Saba \& Halima Kazem, Bridging Modernity and Tradition: the Rule of Law and the Search for Justice, Afghanistan National Human Development Report, (UNDP/CPHD: Kabul 2007), available at undp.org.af.

Ali Wardak, Rule of Law in Afghanistan: An Overview in Petersberg Papers on Afghanistan And the Region, (Danspeckgruber, ed., Princeton University 2009), available at princeton.edu.

Ali Wardak, Rebuilding the Justice System in Afghanistan: Problems and Prospects, 16 EURO-ATLANTIC Q. 21 (2009).

\section{Human Rights}

Sultan Barakat \& Gareth Wardell, Exploited by whom? An alternative perspective on humanitarian assistance to Afghan women, 23 THIRD WORLD QUARTERLY 909 (2002).

Melanie M. Brookes, Reproductive Rights in Afghanistan: Considerations of Abortion Regulation in Light of the Afghan Reconstruction Process, 18 CONN. J. INT'L L. 595 (2003).

Mark A. Drumbl, Rights, Culture, and Crime: The Role of Rule of Law For the Women of Afghanistan, 42 Colum. J. TRANSNAT’L L. 349 (2004).

Mark A. Drumbl, The Taliban's 'Other' Crimes, 23 THIRD WORLD QuARTERLY 1121 (2002).

Mark A. Drumbl, Victimhood in our Neighborhood: Terrorist Crime, Taliban Guilt, and the Asymmetries of the International Legal Order, 81 N.C. L. REV. 1 (2002).

Talya Friedman, Cures to the Enigmatic Taliban Plague: Legal and Social Remedies Addressing Gender Apartheid in Afghanistan, 23 LOY. L.A. INT'L \& COMP. L. REV. 81 (2001).

Tillman Roder, Human Rights Standards in Afghan Courtrooms: The Theory and Reality of the Right to a Fair Trial in Islam AND Human Rights 329 (Peter Lang, ed., Verlag 2010), available at mpil.de. 
J. Alexander Thier, Afghanistan: Minority Rights and Autonomy in a Multi-Ethnic Failed State, 35 STAN. J. INT’L L. 351 (1999).

Shannon A. Wiley, Fighting Back Against the Taliban: The Case for Restoring Afghan Men and Women's Right to Self-Determination, 7 WM. \& MARY J. WOMEN \& L. 523 (2001). 